\title{
Application of dual stable isotope techniques to measure absorption of calcium, magnesium and iron in man
}

Citation for published version (APA):

van den Heuvel, E. G. H. M. (1998). Application of dual stable isotope techniques to measure absorption of calcium, magnesium and iron in man. [Doctoral Thesis, Maastricht University]. Ponsen \& Looijen. https://doi.org/10.26481/dis.19980619eh

Document status and date:

Published: 01/01/1998

DOI:

10.26481/dis.19980619eh

Document Version:

Publisher's PDF, also known as Version of record

\section{Please check the document version of this publication:}

- A submitted manuscript is the version of the article upon submission and before peer-review. There can be important differences between the submitted version and the official published version of record.

People interested in the research are advised to contact the author for the final version of the publication, or visit the DOI to the publisher's website.

- The final author version and the galley proof are versions of the publication after peer review.

- The final published version features the final layout of the paper including the volume, issue and page numbers.

Link to publication

\footnotetext{
General rights rights.

- You may freely distribute the URL identifying the publication in the public portal. please follow below link for the End User Agreement:

www.umlib.nl/taverne-license

Take down policy

If you believe that this document breaches copyright please contact us at:

repository@maastrichtuniversity.nl

providing details and we will investigate your claim.
}

Copyright and moral rights for the publications made accessible in the public portal are retained by the authors and/or other copyright owners and it is a condition of accessing publications that users recognise and abide by the legal requirements associated with these

- Users may download and print one copy of any publication from the public portal for the purpose of private study or research.

- You may not further distribute the material or use it for any profit-making activity or commercial gain

If the publication is distributed under the terms of Article $25 \mathrm{fa}$ of the Dutch Copyright Act, indicated by the "Taverne" license above, 
Application of dual stable isotope techniques to measure absorption of calcium, magnesium and iron in man 
CIP-GEGEVENS KONINKLIJKE BIBLIOTHEEK, DEN HAAG

Van den Heuvel, Ellen GHM van den Heuvel

Application of dual stable isotope techniques to measure absorption of calcium, magnesium and iron in man.

Proefschrift Universiteit Maastricht - met literatuur opgave en samenvatting in het Nederlands.

ISBN 90-9011651-6

Omslag : Margriet Spangenberg (fotograaf)

Druk : Grafisch bedrijf Ponsen \& Looijen BV, Wageningen

Editor : Dirk van der Heij

Het drukken van dit proefschrift werd mede mogelijk gemaakt door financiële steun van de Universiteit Maastricht, TNO Voeding, de Tiense Suikerraffinaderij en
Solvay Pharma. 


\title{
Application of dual stable isotope techniques to measure absorption of calcium, magnesium and iron in man
}

\author{
PROEFSCHRIFT
}

ter verkrijging van de graad van doctor aan de Universiteit Maastricht, op gezag van de Rector Magnificus, Prof. dr. A.C. Nieuwenhuijzen Kruseman, volgens besluit van het College van Decanen, in het openbaar te verdedigen

op vrijdag 19 juni 1998

om 10.00 uur

door

Elisabeth Gertruda Hendrika Maria van den Heuvel 
Promotores:

Prof. dr. ir. W.H.M. Saris

Prof. dr. ir. G. Schaafsma (Landbouw Universiteit

Wageningen)

Beoordelingscommissie: Prof. dr. G. Hornstra (voorzitter)

Prof. dr. D. Halliday

Prof. dr. ir. R.J.J. Hermus

Dr. J.A. Raymakers (Academisch Ziekenhuis Utrecht)

Prof. dr. C. West (Landbouw Universiteit Wageningen) 


\section{Contents}

1 General introduction

2 Methods to measure iron absorption in man: a review

3 Enrichment of ${ }^{57} \mathrm{Fe}$ and ${ }^{58} \mathrm{Fe}$ in young erythroid cells of men, separated by a Percoll density gradient

4 A new method to measure iron absorption from the emrichment of ${ }^{57} \mathrm{Fe}$ and ${ }^{58} \mathrm{Fe}$ in young erythroid cells

5 Iron absorption study with stable isotopes in women with low iron stores: effect of bovine lactoferrin

6 Non-digestible oligosaccharides do not interfere with calcium and non-haem iron absorption in young healthy men

7 Fructo-oligosaccharides stimulate calcium absorption in adolescents

8 Lactulose stimulates calcium absorption in postmenopausal women

9 Feasibility of using stable magnesium isotopes in humans: effect of fructo-oligosaccharides in adolescents

10 General discussion and conclusions

Summary

Samenvatting

Dankwoord

Curriculum vitae

Publications 



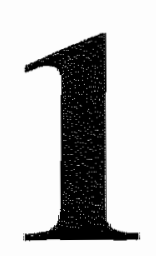

\section{General introduction}

\section{Introduction}

Minerals and trace elements are essential to the diet of human beings and animals. If an essential nutrient is not bioavailable from the diet for a sufficient period of time, a deficiency state will develop. For all essential micronutrients, this will be characterized by the development of biochemical abnormalities and also signs and symptoms characteristic of severe deficiency [1]. Often, deficiency of minerals and trace elements is caused by a low bioavailability rather than by a low or deficient dietary intake. Bioavailability can be defined as the fraction of the ingested nutrient that is absorbed and utilized for normal physiological functions or storage. One of the main determinants of bioavailability is absorption [2]. This can be defined as the percentage of the element ingested that, after the digestion of food, has passed the mucosal cells and is taken up by the blood circulation [3].

Food ingredients that may stimulate or inhibit the absorption of minerals and trace elements are currently receiving much attention. Developments in food technology, molecular biology and nutrition science have led to a growing market for novel and functional foods. Novel foods are just new foods, whereas functional foods are foods with specific additional beneficial effects on health or specific physiological function. Some functional foods are also novel foods.

Before novel foods can enter the market their safety has to be assessed. Such assessments encompass safety from a toxicological as well as a nutritional point of view. The assessment of nutritional safety may include the effects of novel foods on bioavailability of minerals and trace elements. Before any claim of beneficial effects of functional foods on health can be put forward its functionality has to be 
demonstrated. This functionality may include positive effects on bioavailability of minerals and trace elements.

This thesis deals with the development and application of new techniques (using stable isotopes) to measure the intestinal absorption of minerals and trace elements. Our aim was twofold: first, to develop a new method to measure iron absorption with a minimum use of stable isotopes in order to reduce the costs of the method, and second, to study the influence of several potential functional food ingredients on mineral and trace element absorption, using the dual stable isotope technique. The minerals and trace element involved are calcium $(\mathrm{Ca})$, magnesium $(\mathrm{Mg})$ and iron (Fe). The potential functional food ingredients involved are bovine lactoferrin, nondigestible oligosaccharides and lactulose.

This introductory chapter briefly describes methods for studying mineral and trace element absorption. It also provides background information on the metabolism of elements studied in this thesis and on the potential functional food ingredients investigated. Finally, this chapter gives a overview of the research topics addressed in the different chapters of the thesis.

\section{Methods for measuring absorption of minerals and trace elements}

Several methods are available to study the effect of food components on intestinal absorption of minerals and trace elements. These methods include the classical balance technique and various methods in which labels (either radioactive or stable isotopes) are used. An overview of different methods has been published by Sandstrom et al [4]. Using the classical balance technique, apparent (net) absorption can be determined by subtracting the faecal excretion of a nutrient from the dietary intake over a specified period of time. The disappearance of the element between the mouth and the anus does not necessarily mean that the substance has been truly absorbed into the body: it may have been retained in the intestinal mucosa. Furthermore, the gut itself may deliver the element into its lumen via biliary, pancreatic and mucosal secretions or by mucosal cell loss. This entry of endogenous elements into the luminal and, ultimately, the faecal pool mixes the two sources and, 
consequently, results in a lower overall apparent absorption value for the exogenous material. This difficulty can largely be overcome by using an isotopic label of the exogenous element and determining its fractional luminal disappearance between the dietary and faecal pools. By measuring the total size of these pools the relative contributions to the faecal pool of exogenous and endogenous elements can be calculated [5]. Another approach to estimate the endogenous pool is by measuring the appearance of another intravenously injected isotope in the stools. In addition to methods that require faecal sampling, other more convenient and accurate methods can be mentioned in which true intestinal absorption is estimated from the incorporation of isotopes into erythrocytes, the appearance of isotopes in plasma or the excretion of isotopes in urine.

As described in Chapter 2, Fe absorption can be studied most conveniently by determining the incorporation of isotopes into erythrocytes. To account for the redistribution of the orally absorbed Fe between erythrocytes and the rest of the body, a second isotope has to be administered intravenously. This approach assumes that the oral and intravenous labels are metabolized in a similar manner. Barrett et al [6] have demonstrated the applicability of this dual-isotope technique in healthy women. In our studies, this type of method was also used to measure the influence of several potential functional food ingredients on Fe absorption.

When using stable isotopes, this technique has the disadvantage that large doses of stable Fe isotopes are needed to obtain sufficient enrichment in erythrocyles. Therefore, we developed a new method in which the required dose of stable $\mathrm{Fe}$ isotopes can be reduced to one-third. This reduction of the dose of stable isotopes results in a considerable saving in money. Moreover, less interference may be expected from the amount of stable isotopes with normal physiological conditions and total food Fe. Chapters 3 and 4 describe the details of the development of the new method, in which isotope enrichment is measured in isolated young erythroid cells.

The dual-label technique to measure true absorption of $\mathrm{Ca}$ and $\mathrm{Mg}$ differs from that used for $\mathrm{Fe}$ in that no incorporation of Fe into a specific tissue or body compartment is measured. True intestinal absorption of $\mathrm{Mg}$ or $\mathrm{Ca}$ can be estimated by making 
isotope measurements in urine or plasma when an orally administered dose is supplemented by intravenous administration $[7,8]$. The relative ratio of oral versus intravenous isotope may be measured in urine or plasma collected at different time points [9]. However, caution is called for when extending the time of sampling such that isotope excess becomes too low for a reliable estimate of $\mathrm{Mg}$ absorption [10].

\section{Isotopes and food labelling}

Food can be labelled with an isotope by incorporating the isotope biosynthetically into a growing food (intrinsic labelling) or, more easily, by mixing the isotope into the food shortly before consumption (extrinsic labelling) when it exchanges with the native element in the food [11] in such a way that no distinction can be made between the added and the intrinsic element with respect to its position in the food matrix. Intrinsic labelling should be used when insufficient exchange takes place between the different chemical forms, such as for selenium [11]. Extrinsic labelling can be used for non-haem iron [12], calcium [13] and probably also for magnesium [14].

The added isotope could either be $\beta$ - or $\gamma$-radiation-emitting isotopes or a stable isotope [4]. Table 1 shows the isotopes of Fe, $\mathrm{Ca}$ and $\mathrm{Mg}$. The 'Atom\%' mentioned in the table is also referred to as "natural abundance".

The main factors to be considered when choosing between radioactive and stable isotopes are, first of all, ethical aspects, followed by availability, costs of isotopes and the access to analytical instruments and skills [4]. For ethical reasons, stable isotopes were used in the experiments described in this thesis. The isotope enrichments were measured by inductively coupled plasma mass spectrometry.

\section{Inductively coupled plasma mass spectrometer (ICP-MS)}

ICP-MS appears to have considerable potential for absorption studies with inorganic isotopes. It is also a promising means of studying mineral speciation [4]. The sample solution to be analysed is transferred by a peristaltic pump to a nebulizer which converts the solution into an aerosol. The aerosol is carried by argon gas into the 
centre of the ICP torch, where the high-temperature plasma vaporizes and ionizes the sample, and directs ions into the mass spectrometer, where the elements of interest are detected on the basis of the mass-to-charge $(\mathrm{m} / \mathrm{z})$ ratio [15]. The commercial instruments now available are more competitive in price and analysis is faster. Less sample preparation is required and in some cases isotopic ratios of several minerals can be measured in a single sample [4].

Table 1 Isotopes of $\mathrm{Fe}, \mathrm{Ca}$ and $\mathrm{Mg}$

\begin{tabular}{|c|c|c|c|c|}
\hline & \multicolumn{2}{|c|}{ Radioactive isotopes } & \multicolumn{2}{|c|}{ Stable isotopes } \\
\hline & Mass No. & Half-life & Mass No. & Atom $\%$ \\
\hline \multirow[t]{4}{*}{$\mathrm{Fe}$} & 55 & $2.6 \mathrm{y}$ & 54 & 5.8 \\
\hline & 59 & $45.1 \mathrm{~d}$ & 56 & 91.72 \\
\hline & & & 57 & 2.2 \\
\hline & & & 58 & 0.28 \\
\hline \multirow[t]{6}{*}{$\mathrm{Ca}$} & 45 & $165 d$ & 40 & 96.941 \\
\hline & 47 & $4.53 \mathrm{~d}$ & 42 & 0.647 \\
\hline & & & 43 & 0.135 \\
\hline & & & 44 & 2.086 \\
\hline & & & 46 & 0.004 \\
\hline & & & 48 & 0.187 \\
\hline \multirow[t]{3}{*}{$\mathrm{Mg}$} & 28 & $21 \mathrm{~h}$ & 24 & 78.99 \\
\hline & & & 25 & 10.00 \\
\hline & & & 26 & 11.01 \\
\hline
\end{tabular}

From Sandströ̀m et al [4]

Although ICP-MS has several advantages over other techniques, it suffers in some cases from molecular interferences of varying sources. The most obvious are isobaric interferences at low masses, notably ${ }^{40} \mathrm{Ar}$ from the plasma with ${ }^{40} \mathrm{Ca}$. They can usually be foreseen and do not pose serious problems during analysis. In addition to these molecular interferences, polyatomic ions originating from the plasma (Ar), from the matrix $(\mathrm{O}, \mathrm{H}$ and often $\mathrm{H}, \mathrm{P}, \mathrm{S}, \mathrm{Cl})$ and from air surrounding plasma $(\mathrm{C}, \mathrm{N}$, $\mathrm{O})$ exist [16]. For instance, ${ }^{40} \mathrm{Ar}{ }^{16} \mathrm{O}$ interferes with ${ }^{56} \mathrm{Fe}$. A correction for these 
polyatomic interferences can be made using $\mathrm{HNO}_{3}$ and internal standard solutions. Besides knowledge of these interferences, it is also important to know to what extent they contribute to the total signal of the analyte. The extent of interference can vary from day to day within a factor of two under normal operating conditions [16]. The solution for this day-to-day variation is to measure on the same day the molecular interference in, for example, blank or standard solutions. Alternatively, samples that belong together can be analysed within one day.

In the next chapters, the exact procedures are described for the measurement by ICPMS of the following ratios: ${ }^{57} \mathrm{Fe} /{ }^{56} \mathrm{Fe},{ }^{58} \mathrm{Fe} /{ }^{156} \mathrm{Fe},{ }^{44} \mathrm{Ca} /{ }^{43} \mathrm{Ca},{ }^{48} \mathrm{Ca} /{ }^{43} \mathrm{Ca},{ }^{25} \mathrm{Mg} /{ }^{24} \mathrm{Mg}$ and ${ }^{26} \mathrm{Mg} /{ }^{24} \mathrm{Mg}$.

\section{Iron, calcium and magnesium}

Although essentiality of inorganic elements is not always easy to prove, those considered essential for normal body functions include $\mathrm{Ca}, \mathrm{Mg}$ and $\mathrm{Fe}$. Well defined dietary deficiencies have been described in man for $\mathrm{Ca}$ and $\mathrm{Fe}$ and, under special dietary circumstances such as total parenteral nutrition, also for $\mathrm{Mg}$ [17].

\section{Iron}

Total body $\mathrm{Fe}$ averages ca. $3.8 \mathrm{~g}$ in men and ca. $2.3 \mathrm{~g}$ in women. Fe-containing compounds in the body are grouped in two categories, functional (known to serve a metabolic or enzymatic function) and storage (used for storage and transport of $\mathrm{Fe}$ ). About two thirds of total body $\mathrm{Fe}$ are functional $\mathrm{Fe}$, and most of this $\mathrm{Fe}$ is in the form of haemoglobin $(\mathrm{Hb})$ in circulating erythrocytes. Nutritional Fe deficiency is commonly regarded as a Fe supply insufficient to meet the functional Fe requirement after storage has been depleted [18]. There are three stages of Fe deficiency: depletion of Fe stores, Fe deficient erythropoiesis and Fe deficiency anaemia, which range in severity from reduced body stores with no effect on functional iron to severe anaemia with multiple deficiencies of tissue iron enzymes [19]. Fe deficiency during pregnancy has been associated with low birth weight, premature delivery, and even perinatal and foetal death. During childhood, Fe deficiency leads to impaired 
cognitive performance and motor development, and decreased growth. Anaemic adults suffer from reduced ability to perform physical work. Fe deficiency also impairs the normal defence system against infections [20].

$\mathrm{Fe}$ metabolism is characterized by the fact that $\mathrm{Fe}$ absorption from the gastrointestinal tract is the primary regulatory mechanism of Fe balance [18]. Because little endogenous $\mathrm{Fe}$ is excreted, absorption of $\mathrm{Fe}$ is synonymous with its bioavailability [21]. In normal human beings the small intestine proximal to the midjejenum may be capable of more efficient Fe absorption than the distal portion. In Fe deficiency enhanced absorption extends distally to about the mid-jejenum [22].

The process of $\mathrm{Fe}$ absorption can be divided into three stages: $\mathrm{Fe}$ uptake, intraenterocyte transport, and storage and extra-enterocyte transfer. During the intestinal phase of digestion, Fe binds to specific mucosal membrane sites, is internalized, and is subsequently either retained by the mucosal cell or transported to the basolateral membrane, where it is bound to transferrin in the plasma pool [23]. In normal subjects, about two thirds of the internalized Fe is temporarily retained in the gut wall and re-excreted into the lumen in the following weeks, whereas one third of the Fe taken up initially by the absorptive cells is finally transferred to the blood and tissue compartments [24]. As the intra-enterocyte Fe content and ferritin levels may be responsive to body $\mathrm{Fe}$ stores $[25,26]$, during Fe deficiency the amount of internalized Fe transferred to the blood and tissue compartments probably may be higher than one third.

Fe absorption is influenced by intraluminal (dietary inhibitors, enhancers), mucosal (surface, motility) and somatic factors (erythropoeiesis, hypoxia) [23]. The two main. factors that influence $\mathrm{Fe}$ absorption are body stores and rate of erythropoiesis [27, 28]. However, in infants dietary factors inhibiting Fe absorption appear to be more important than Fe stores in determining the extent of Fe absorption [29].

\section{Calcium}

$\mathrm{Ca}$ is the most abundant divalent cation in the body, making up 1.5-2.0\% of its total weight [30]. More than $99 \%$ of that amount is found inside the skeleton. Bone mass 
in a given individual is genetically programmed, but final genetic expression is modulated both qualitatively and quantitatively by environmental factors. Thus, in the absence or with reduced availability of the bone minerals calcium and phosphate, the expression of genetically determined skeletal development is diminished: bone is thinner and therefore weaker at any age, and the risk of fracture is greater [31]. Knowledge of $\mathrm{Ca}$ homeostasis is essential to our insight into the relation between $\mathrm{Ca}$ and osteoporosis. It is crucial for blood coagulation, muscle function and stimulus conduction via nerves that the plasma $\mathrm{Ca}$ level is kept within narrow boundaries $(90-$ $110 \mathrm{mg} / 1)$. Ca homeostasis proceeds via three types of tissue, the skeleton, the kidneys and the intestines, and is influenced by the hormones calcitonine, parathormone (PTH) and calcitriol (active vitamin D). In case of a prolonged inadequacy of dietary $\mathrm{Ca}$ intake the body will preferentially use the Ca provided for $\mathrm{Ca}$ homeostasis at the expense of maintenance of skeletal Ca. According to Nordin [32], a negative Ca balance seems to have at least a contributory, if not a causal, role in most forms of osteoporosis, because established osteoporosis of all types is commonly associated with malabsorption of calcium and/or high obligatory urinary calcium excretion.

Most $\mathrm{Ca}$ absorption in man takes place in the small intestine [33]. By two main routes $\mathrm{Ca}$ moves across the intestinal epithelium: between cells (paracellularly) and through the cell (transcellularly). Paracellular transport occurs throughout the intestine [31] and is the dominant pathway in the distal small bowel. The nonsaturable component of the rate of disappearance is primary, if not exclusively, consistent with the paracellular pathway [34]. The transcellular movement is saturable, regulated (largely by vitamin D), and takes place in the proximal intestine, mostly the duodenum [31]. In response to homeostatic controls that operate to optimize the concentration of $\mathrm{Ca}$ ions in the extracellular fluid, this active transport can be up- or down-regulated.

At any level of usual $\mathrm{Ca}$ intake, inter-individual variance in $\mathrm{Ca}$ absorption is surprisingly large. About $26 \%$ of this variance can be explained by differences in usual Ca intake [35]. Serum 25(OH)D, mean mouth-to-caecum transit time and 
fasting urinary $\mathrm{Ca}$-to-creatinine ratio together may explain about $44 \%$ of the variance in $\mathrm{Ca}$ absorption [36]. Intestinal $\mathrm{Ca}$ absorption may also be affected by several dietary factors, such as lactose, lysine, arginine, oxalate, phytate and phosphate [34, 37]. A variety of hormones and drugs may increase or decrease intestinal $\mathrm{Ca}$ absorption, either via direct interactions on enterocyte function or indirectly, through alterations in levels of $1,25(\mathrm{OH})_{2} \mathrm{D}_{3}$ [34]. In man, intestinal absorption of $\mathrm{Ca}$ decreases with advancing age $[35,37]$.

\section{Magnesium}

The $\mathrm{Mg}$ store in adults is ca. $24 \mathrm{~g}$ and is about equally divided over bones and soft tissue [38]. $\mathrm{Mg}$ plays an essential role in a very wide range of fundamental cellular reactions. Hence it is not surprising that deficiency in the organism may lead to serious biochemical and symptomatic changes [39]. Pathological states resulting from $\mathrm{Mg}$ deficiency are well established: myocardial damage, arterial hypertension, cardiac arrhythmia, and kidney stones [40].

The efficient intestinal and renal conservation and excretory mechanisms in normal individuals permit $\mathrm{Mg}$ homeostasis within a wide range of intakes. Because about $70 \%$ of serum $\mathrm{Mg}$ is ultrafiltrable, the kidney plays a critical role in $\mathrm{Mg}$ homeostasis [39].

$\mathrm{Mg}$ is absorbed throughout the intestine. However, the predominant site is the distal small intestine [34, 41, 42]. Passive diffusion, solvent drag and active transport all participate in intestinal $\mathrm{Mg}$ absorption [42]. Absorption of $\mathrm{Mg}$ through the paracellular pathway occurs especially in the more 'leaky' epithelia such as the small intestine through the tight junctions [43]. Active transport of $\mathrm{Mg}$ has only been conclusively demonstrated in the colon, albeit indirect evidence has also been found for the existence of an active cellularly mediated component of $\mathrm{Mg}$ transport in the small intestine [42]. Under conditions of usual dietary $\mathrm{Mg}$ intake it is not clear which process predominates [41]. However, passive diffusion and solvent drag mechanisms of $\mathrm{Mg}$ absorption then seem to predominate. Probably, the active component is saturated under conditions of usual dietary $\mathrm{Mg}$ intake and, therefore, may only be 
critical to total $\mathrm{Mg}$ absorption in the intestine under conditions of rapid growth or extremely low dietary $\mathrm{Mg}$ intake [42].

Numerous hormones may influence $\mathrm{Mg}$ absorption, such as parthyroid hormone, calcitonin, growth hormone, aldosterone and vitamin D [44]. The findings of Graham et al [45] suggest that $\mathrm{Mg}$ absorption is influenced by the load presented to the intestinal mucosa, but is not linearly related to the load. Because urinary $\mathrm{Mg}$ excretion will be raised or lowered after stimulation or impairment of apparent $\mathrm{Mg}$ absorption, respectively, the effects of dietary components on $\mathrm{Mg}$ absorption probably are critically important only at low $\mathrm{Mg}$ intakes. At low intakes, differences in $\mathrm{Mg}$ absorption may be expected to influence $\mathrm{Mg}$ retention and thus can either induce or abolish $\mathrm{Mg}$ deficiency [44].

\section{Functional foods and their role in element bioavailability}

According to a Japanese concept, functional foods exert specific health benefits beyond traditional nutritional value and are primarily intended for daily consumption by the general population to help prevent diet-related chronic diseases. In western countries the concept of functional foods tends to include foods that have been modified or processed in such a way that their traditional nutritional value, the balance of nutrients or the bioavailability of nutrients in the food has improved [46]. In this thesis, the effects of bovine lactoferrin, non-digestible oligosaccharides and lactulose on the absorption of $\mathrm{Fe}, \mathrm{Ca}$ and/or $\mathrm{Mg}$ are described. These potential functional food ingredients were selected because of their enhancing effect on mineral and trace element absorption in animals. Little is known of this effect in man.

\section{Lactoferrin $(L f)$}

Traditionally, dietary proteins serve as a source of essential and non-essential amino acids. In the past decade it has become clear that, beyond this important function, some proteins and protein-derived peptides can exert specific biological effects [46]. A typical example is lactoferrin, a glycoprotein. Owing to its Fe-binding properties, 
Lf has been proposed to play a role in Fe uptake by the intestinal mucosa and to act as a bacteriostatic agent by withholding Fe from Fe-requiring bacteria. Its presence in neutrophils and its release during inflammation suggest that $L F$ is also involved in phagocytic killing and immune response. Additionally, Lf may function in ways unrelated to Fe-binding, for example as a growth factor and as a bactericidal agent [47]. The experiment described in this thesis was carried out to elucidate the role of lactoferrin in the intestinal Fe absorption during Fe deficiency.

Results of animal experiments have shown that, under conditions of elevated Fe requirements, bovine Lf is likely to increase Fe absorption by virtue of several possible mechanisms. The close biochemical relationship between Lf and transferrin suggests that $\mathrm{Lf}$, like transferrin, possesses a Fe transport role to the intestinal mucosa in a readily absorbed form [48]. This is underscored by the results of an in vitro study showing that Lf and Lf digested with pepsin and trypsin could dissolve Fe. This suggests that Lf, when orally administered, could dissolve ferric Fe after digestion in the intestine [49]. Another mechanism involves the presence of $\mathrm{Lf}$ receptors in the human intestine, which may bind bovine Lf [50]. The number of Lf receptors increases in response to a decrease in intracellular Fe content of human enterocytes. Possibly, Lf receptors throughout the intestine play a role in Fe absorption, particularly during Fe deficiency [51].

As reported in Chapter 5 , true Fe absorption was studied in women with a low Fe status, who were given four different doses of bovine Lf according to a randomized cross-over design. Lf doses were chosen such that Lf was differently saturated with $\mathrm{Fe}$, because the Fe-saturated forms of human and bovine Lf appear to be more resistant to intestinal proteolytic degradation than partially Fe-saturated forms [52]. Besides, the affinity of partially saturated Lf seems to be lower for the brush-border membrane receptor than for Lf saturated with Fe [53].

\section{Non-digestible oligosaccharides}

Non-digestible oligosaccharides (NDO) are not absorbed or digested in the small intestine of man and animals. These compounds should reach unaltered the end of 
the small intestine and the large intestine in which microbial activity is high and which could be used as selective substrates for beneficial microorganisms. This may result in an increase in bacterial biomass (especially bifidobacteria), an increase in faecal mass, and a decrease in caeco-colonic intraluminal $\mathrm{pH}$ due to the production of fermentation products including short-chain fatty acids (SCFA) that exerts systemic effects on lipid metabolism $[54,55]$. In conclusion, these NDO seem to have beneficial properties and could therefore be seen as functional food ingredients. Another promising observation in terms of health effect is their enhancing effect on mineral and trace element absorption.

In rat experiments, a positive effect of $\mathrm{NDO}$ on $\mathrm{Fe}, \mathrm{Mg}$ and $\mathrm{Ca}$ absorption has been found [56-59]. Also in man, a positive effect of the NDO inulin on Ca absorption has been found [60]. Several hypotheses have been proposed for the effect of these nondigestible carbohydrates on mineral absorption. Due to their osmotic action, additional fluid might increase the distention and permeability of the intracellular junctions between enterocytes, thereby increasing the passive absorption of $\mathrm{Ca}$ and other elements [56]. Another hypothesis is an increased soluble pool of the mineral through acidification of the gut contents [57, 61]. It has also been proposed that SCFA may improve both $\mathrm{Ca}$ and $\mathrm{Mg}$ absorption through an exchange of intracellular $\mathrm{H}^{+}$for $\mathrm{Ca}^{2+}$ or $\mathrm{Mg}^{2+}$ present in the distal colon $[62,63]$.

As described in Chapter 6, a randomized cross-over study was conducted to study the effect of NDO on Fe and Ca absorption. Because Ca is important during growth in order to attain peak bone mass and, thus, prevent or delay osteoporosis, the effect of oligofructose on Ca absorption was also studied in adolescent boys (Chapter 7).

In addition to $\mathrm{Ca}$ absorption, $\mathrm{Mg}$ metabolism was also measured in these adolescent boys, as reported in Chapter 9. In this study the objective was to measure $\mathrm{Mg}$ absorption with the same dual stable isotope technique as used for measurement of Ca absorption.

\section{Lactulose}

Another poorly digestible but well-fermentable carbohydrate, lactulose, has also 
been shown to have beneficial properties in relation to its effects on intestinal microflora. Until recently, this synthetic disaccharide is better known as a drug prescribed to treat constipation and hepatic encephalopathy [64].

During fermentation of lactulose, SCFA, lactic acid, hydrogen or methane are produced [64]. As lactulose is most likely to be metabolized in a similar way as NDO, mechanisms similar to those described for NDO have been proposed for the effect of lactulose on mineral and trace element absorption $[56,65,66]$.

In Chapter 8, the effect of lactulose on $\mathrm{Ca}$ absorption in postmenopausal women is reported. To our knowledge, this was the first time that the effect of lactulose on human $\mathrm{Ca}$ absorption was investigated.

In Chapter 10, the conclusion from the experiments described in earlier chapters is discussed.

To complete this chapter, the aims of this thesis are defined more explicitly:

- To develop a new method to measure iron absorption with a minimum use of stable isotopes in order to reduce the costs of the method

- To study the effect of bovine lactoferrin on iron absorption in subjects with a low iron status

- To study the effect of non-digestible oligosaccharides on calcium, iron and magnesium absorption

- To study the effect of lactulose on calcium absorption

\section{References}

1 Shenkin A, Voss AC \& Allison S. Micronutrients and outcome. Nutr 1997;13:825-828.

2 Jackson MJ. The assessment of bioavailibility of micronutrients: introduction. Eur J Clin Nutr $1997 ; 51: S 1-S 2$.

3. Van Dokkum W. Significance of iron bioavailability for iron recommendations, Biol Trace Elem Res 1992;35:1-11.

4 Sandström B, Fairweather-Tait S, Hurrell R \& Van Dokkum W. Methods for studying mineral and trace element absorption in humans using stable isotopes. Nutr Res Rev 1993;6:71-95.

5 Aggett PJ. Iron, copper, and zine absorption and turnover; the use of stable isotopes. Eur $J$ Pediatr 1997;156:S29-\$34. 
6 Barrett $\mathrm{JF}^{*}$, Whittaker $\mathbf{P G}$, Williams JG \& Lind $T$. Absorption of non-haem iron in normal women measured by the incorporation of two stable isotopes into erythrocytes. Clin $S c i$ $1992 ; 83: 213-219$.

7 Schaafsma G. Bioavailability of calcium and magnesium. Eur J Clin Nutr 1997;51:S13-S16.

8 Schwartz $\mathbf{R} .{ }^{25} \mathrm{Mg}$ as a probe in research on the role of magnesium in nutrition and metabolism. Federation Proc 1982;41:2709-2713.

9 Griessen M, Jung A, Cochet B, Bartholdi P, Gaspoz JM, Infante F, Donath A, Loizeau E \& Courvoisier B. A simple method for measurement of intestinal calcium absorption in humans by double-isotope technique. $J$ Lab Clin Med 1985;105:641-646.

10 Cary EE, Wood RJ \& Schwartz R. Stable Mg isotopes as tracers using ICP-MS. J Micronutr Anal 1990;8:13-22.

11 Fairweather-Tait SJ. Bioavailability of dietary minerals. Biochem Soc Trans 1996;24:775-780.

12 Boza JJ, Fox TE, Eagles J, Wilson PD \& Fairweather-Tait SJ. The validity of extrinsic stable isotopic labeling for mineral absorption studies in rats. J Nutr 1995;125:1611-1616.

13 Nickel KP, Martin BR, Smith DL, Smith JB, Miller GB \& Weaver CM. Calcium bioavailability from bovine milk and dairy products in premenopausal women using intrinsic and extrinsic labeling techniques. J Nutr $1996 ; 126: 1406-1411$.

14 Schwartz R, Grunes DL, Wentworth RA \& Wien EM. Magnesium absorption from leafy vegetables intrinsically labelled with the stable isotope ${ }^{26} \mathrm{Mg} . J$ Nutr $1980 ; 110: 1365-1371$.

15 Nuttall KI, Gordon WH \& Ash KO. Inductively coupled plasma mass spectrometry for trace element analysis in the clinical laboratory. Ann Clin Lab Sci 1995;25:264-271.

16 Vanhoe H. A review of the capabilities of ICP-MS for trace element analysis in body fluids and tissues. J Trace Elem Electrolytes Health Dis 1993;7:131-139.

17 Fairweather-Tait $\mathbf{S} \&$ Hurrell R. Bioavailability of minerals and trace elements. Nutr Res Rev 1996;9:295-324.

18 Yip R \& Dallman PR. Iron. In: Present knowledge in nutrition. 7th edit. Ziegler EE, Filer LJ, eds. Washington DC: ILSI Press, 1996:277-292.

19 Fairweather-Tait S. Iron. Int I Vitant Nutr Res 1993;63:296.301.

20 Schultink W \& Gross R. Iron deficiency alleviation in developing countries. Nutr Res Rev 1996;9:281-293.

21 Hurrell RF. Bioavailability of iron. Eur J Clin Nutr 1997;51:S4-S8.

22 Wheby MS. Site of iron absorption in man. Scand J Haemat 1970;7:56-62.

23 Beard $\mathrm{IL} \&$ Dawson HD. Iron. In: Handbook of nutritionally essential mineral elements. O'Dell BL, Sunde RA, eds. New York: Marcel Dekker inc, 1997:275-334.

24 Werner $\mathrm{E}$, Roth $\mathrm{P}$ \& Hansen C. Intestinal absorption of metals. In: Age related factors in radionuclide metals and dosimetry. Gerber, ed. 1987:35-42.

25 Tapia V, Atredondo $M$ \& Núñez MT. Regulation of Fe absorption by cultured intestinal epithelia (Caco-2) cell monolayers with varied Fe status. Am J Physiol 1996;271:G443-G447.

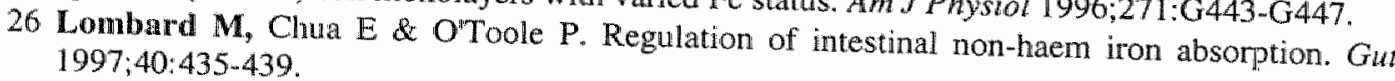

27 Bothwell TH. Overview and mechanisms of iron regulation. Nutr Rev 1995;53:237-245.

28 Anderson G.J. Control of iron absorption. J Gastroenterol Hepatol 1996;11:1030-1032. 
29 Fomon SJ, Ziegler EE, Nelson SE, Serfass RE \& Frantz JA. Erythrocyte incorporation of iron by 56-day-old infants fed a 58Fe-labeled supplement. Pediatr Res 1995;38:373-378.

30 Arnaud CD \& Sanchez SD. Calcium and phosphorus. In: Present knowledge in wuririon. 7 th edit. Ziegler EE, Filler LJ, eds. Washington DC: ILSI Press, 1996:245-255.

31 Bronner F. Calcium. In: Handbook of mutritionally essential mineral elements. ODell BL, Sunde RA, eds. New York: Marcel Dekker, Inc. 1997:13-62.

32 Nordin BEC. Calcium and osteoporosis. Nut 1997;13:664-686.

33 Barger-Lux MJ, Heaney RP\& Recker RR. Time course of calcium absorption in humans: evidence for a colonic component. Calcif Tissue Int 1989;44:308-311.

34 Klugman VA \& Favus MJ. Intestinal absorption of calcium, magnesium and phosphorus. In: Kidney stones: medical and surgical management. Coe FL, Favus MJ, Pak CYC Parks JH, Preminger GM, eds. Philadelphia: Lippincott-Raven Publishers, 1996:201-221.

35 Heaney RP, Recker RR, Stegman M R \& Moy AJ. Calcium absorption in women: relationships to calcium intake, estrogen status, and age. J Bone Miner Res 1989;4:469-475.

36 Barger-Lux MJ \& Heaney RP. Determinants of Ca absorption. Challenges of Modern Medicine $1.995 ; 7: 243-251$.

37 Civitelli R \& Avioli LV. Calcium, phosphate, and magnesium absorption. In: Physiology of the gastrointestinal tract. Johnson LR, ed. New York: Raven Press, 1994:2173-2181.

38 Elin RJ. Laboratory tests for the assessment of magnesium status in humans. Magnes Trace Elem 1991;10:172-181.

39 Shils ME. Magnesium. In: Present knowledge in nutrition. 7th edit. Ziegler EE, Filer LJ, eds. Washington DC: ПLSI Press, 1996:224-232.

40 Bronzetti G, Croce CD \& Davini T. Magnesium: its role in cellular functions-a review. $J$ Environ Pathol Toxicol Oncol 1995;14:197-204.

41 Kayne LH \& Lee DB. Intestinal magnesium absorption. Miner Electrolyte Metab 1993; 19:210-217.

42 Hardwick LL, Jones MR, Brautbar N \& Lee DB. Site and mechanism of intestinal magnesium absorption. Miner Electrolyte Metab 1990;16:174-180.

43 Ebel H. Intestinal magnesium absorption. Metal ions in biological systems $1990 ; 26: 227-248$.

44 Brink EJ \& Beynen AC. Nutrition and magnesium absorption: a review. Progr Food Nutr Sci $1992 ; 16: 125-162$.

45 Graham LA, Caesar JJ \& Burgen ASV. Gastrointestinal absorption and excretion of $28 \mathrm{Mg}$ in man. Metab 1960;9:646-659.

46 Schaafsma G. Products with specific health benifits against digestive disorders. Vitafoods International, 11-13 march 1997, Kopenhagen.

47 Lönnerdal B \& Iyer S. Lactoferrinmolecular structure and biological function. Anmu Rev Nutr 1995; 15:93-110.

48 Brock JH. Annotation. Lactoferrin in human milk: its role in iron absorption and protection against enteric infection in the newbom infant. Arch Dis Child 1980;55:417-421.

49 Kawakami $\mathbf{H}$, Dosako S \& Nakajima I. Effect of lactoferrin on iron sollubility under neutral conditions. Biosci Biotech Biochem 1993;57:1376-1377.

50 Oguchi S, Walker WA \& Sanderson IR. Iron saturation alters the effect of lactoferrin on the 
proliferation and differentiation of human enterocytes (Caco-2 cells). Biol Neonate $1995 ; 67: 330-339$.

51 Mikogami T, Marianne T \& Spik G. Effect of intracellular iron depletion by picolinic acid on expression of the lactoferrin receptor in the human colon carcinoma cell subclone HT29-18-Cl. Biochem J 1995;308:391-397.

52 Spik G, Brunet B, Mazurier-Dehaine C, Fontaine G \& Montrewil J. Characterization and properties of the human and bovine lactotransferrins extracted from the faeces of newborn infants. Acta Paediatr Scand 1982;71:979-985.

53 Davidson LA \& Lönnerdal B. Fe-saturation and proteolysis of human lactoferrin: effect on brush-border receptor-mediated uptake of Fe and Mn. Am J Physiol 1989;257:G930-G934.

54 Gibson GR \& Roberfroid MB. Dietary modulation of the human colonic microbiota: introducing the concept of prebiotics. J Nutr 1995;125:1401-1412.

55 Roberfroid M. Dietary fiber, inulin, and oligofructose: a review comparing their physiological effects. Crit Rev Food Sci Nutr 1993;33:103-148.

56 Brommage $\mathbf{R}$, Binacua $\mathrm{C}$. Antille $\mathrm{S} \&$ Carrie AL. Intestinal calcium absorption in rats is stimulated by dietary lactulose and other resistant sugars. J Nutr 1993;123:2186-2194.

57 Ohta A, Ohtsuki M, Baba S, Takizawa $T$, Adachi $T$ \& Kimura $S$. Effects of fructo-oligosaccharides on the absorption of iron, calcium and magnesium in iron-deficient anemic rats. J Nutr Sci Vitaminol 1995;41:281-291.

58 Chonan O, Matsumoto $\mathrm{K}$ \& Watanuki $\mathrm{M}$. Effect of galacto-oligosaccharides on calcium absorption and preventing bone loss in ovariectomized rats. Biosci Biotech Biochem 1995;59:236-239.

59 Levrat MA, Rémésy C \& Demigné C. High proponic acid fermentations and mineral accumulation in the cecum of rats adapted to different levels of inulin. $J$ Nutr 1991;121:1730-1737.

60 Coudray C, Bellanger J, Castíglia-Delavaud C, Vermorel V \& Rayssignuier Y. Effect of soluble or partly soluble dlietary fibres supplementation on absorption and balance of calcium, magnesium, iron and zinc in healthy young men. Eur J Clin Nutr 1997;51:375-380.

61 Younes H, Demigné C \& Rémesy C. Acidic fermentation in the caecum increases absorption of calcium and magnesium in the large intestine of the rat. Br J Nutr 1996;75:301-314.

62 Trinidad TP, Wolever TM \& Thompson LU. Effect of acetate and propionate on calcium absorption from the rectum and distal colon of humans. Am J Clin Nurr 1996;63:574-578.

63 Scharrer $\mathbb{E}$ \& Lutz $T$. Effects of short chain fatty acids and $\mathrm{K}$ on absorption of $\mathrm{Mg}$ and other cations by the colon and caecum. Z Ermährungswiss 1990;29:162-168.

64 Havenaar R. Lactulose:a review on effects, clinical results and safety aspects in relation with its influence on colonic environment. In: TNO report V96-297.

65 Heijnen AM, Brink EJ, Lemmens AG \& Beynen AC. Ileal pH and apparent absorption of magnesium in rats fed on diets containing either lactose or lactulose. $B r J$ Nutr 1993;70:747-756.

66 Demigné C, Levrat MA \& Rémésy C. Effects of feeding fermentable carbohydrates on the cecal Notr 1989;119:1625-1630. 


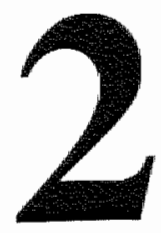

\title{
Methods to measure iron absorption in man: a review
}

Ellen GHM van den Heuvel, Wim van Dokkum and Gertjan Schaafsma Food Reviews International 1997;13:91-102.

\begin{abstract}
In this paper different methods for measuring iron absorption by using stable or radioisotopes are reviewed. Methods using stable isotopes are of special interest because of the absence of radioactive exposure. The oldest method is faecal monitoring, which has two drawbacks: the necessity to obtain a complete collection of the unabsorbed isotopes and sample inhomogeneity. The plasma iron appearance test seems to be a promising method, although interfering factors should be taken into account, such as gastrointestinal transit time and rate of entry of iron from the gastrointestinal mucosal cell into the blood stream. The method of choice for measuring iron absorption seems to be the analysis of the incorporation of both an orally and an intravenously administered stable iron isotope into erythrocytes. The only disadvantage of this method is the rather large amount of stable isotopes required. This may be overcome by measuring incorporation of the isotopes into a reticulocyte-rich erythrocyte fraction.
\end{abstract}

\section{Introduction}

Iron (Fe)-deficient anaemia is probably the most prevalent human nutritional disorder leading to reduced work performance and increased morbidity and mortality [1]. Individuals particularly vulnerable to Fe deficiency are those with high $\mathrm{Fe}$ 
requirements: children, pregnant women, persons with high $\mathrm{Fe}$ loss due to haemorrhage [2] or parasitic infections [3] and women with excessive and/or frequent menstrual losses [2]. Moreover, strenuous physical training increases Fe needs and some dietary compounds may decrease Fe bioavailability and contribute to Fe deficiency.

A low bioavailability is frequently a dominant causal factor in Fe deficiency, rather than a low Fe intake [4]. Iron bioavailability includes absorption, transport to relevant body tissues and conversion into physiologically active species [5]. Intestinal absorption is the primary mechanism by which Fe balance is controlled in healthy individuals [6]. Therefore, a fundamental understanding of dietary factors affecting availability of Fe for absorption and of the mechanisms regulating Fe absorption is needed to optimize Fe nutrition [7]. For studying these factors and mechanisms, a sensitive and accurate method for measuring Fe absorption is required.

Various methods for measuring Fe absorption are available. Traditionally, apparent absorption has been investigated by the use of the chemical balance technique, namely the difference between intake and faecal excretion of Fe. However, stools collected during a chemical balance study will contain Fe from two different origins, i.e. unabsorbed and endogenously secreted Fe. Using labels (radioactive or stable isotopes), Fe can be traced and the unabsorbed fraction of Fe can be separated from other sources of Fe in faecal samples [8]. True absorption can thus be estimated. Next to faecal monitoring, more convenient methods have been described in which the isotopes are detected in blood instead of faeces.

In this review, Fe isotopes in general and the routes applicable after Fe administration will be discussed first. Second, three stable isotope techniques measuring Fe absorption will be described: faecal monitoring, the plasma Fe appearance test and the incorporation of Fe into erythrocytes. Finally, an alternative and promising method in which the incorporation of stable Fe isotopes into reticulocytes is measured will be discussed. 


\section{Iron isotopes}

Table 1 shows all $\mathrm{Fe}$ isotopes used in nutrition research.

Table 1 Radioactive and stable isotopes of $\mathrm{Fe}^{\mathrm{i}}$

\begin{tabular}{cccc}
\hline \multicolumn{2}{c}{ Radioactive isotopes } & \multicolumn{2}{c}{ Stable isotopes } \\
\hline Mass No. & Half-life & Mass No. & Atom \% \\
\hline \multirow{2}{*}{55} & $2.6 \mathrm{y}$ & 54 & 5.8 \\
59 & $45.1 \mathrm{~d}$ & 56 & 91.72 \\
& & 57 & 2.2 \\
& & 58 & 0.28 \\
\hline
\end{tabular}

Sandström et al [9]

Contrary to the use of radioactive labels, the use of stable isotopes is easily allowed in healthy subjects because of the absence of radioactive exposure. Stable isotopes exist in nature in fixed ratios [10]. Consequently, when applied in absorption studies, corrections must be made for background levels when they are used as a label [11]. To be useful as a label, the isotope must have a low natural abundance [10]. Woodhead et al [12] concluded that ${ }^{58} \mathrm{Fe}$ is a satisfactory tag for studies of non-haem Fe absorption from meals. This conclusion is based on the similarity of their results with those obtained in adults with radioisotopes.

Radioactive isotopes are less suitable for multi-element studies and multiple administrations. Besides the objection of accumulative radiation dose, there are also measurement difficulties due to overlapping energy spectra [9]. With stable isotopes Fe absorption can be measured simultaneously from different test foods labelled with different stable Fe isotopes. This has been carried out by Kastenmayer et al [13], Abrams et al [14] and Fairweather-Tait et al [15].

The primary drawback of stable isotope techniques is the large amount of isotope needed, which could interfere with maintenance of physiological conditions during absorption tests. Moreover, both the enriched isotopes and the analytical work involved in the studies are expensive [8]. Two approaches are available to measure stable isotopic enrichment, namely neutron activation analysis and mass 
spectrometry techniques. Neutron activation is based on the interaction of thermal neutrons from a medium- to high-flux nuclear reactor with the nuclei of stable isotopes. The mass spectrometer uses a magnetic sector, which separates masses in a magnetic field [9]. These methods' pros and cons are discussed by Turnlund [16]. The food to be studied can be labelled extrinsically or intrinsically with Fe isotopes. Intrinsic labelling of plants or animals involves the biological incorporation of an $\mathrm{Fe}$ isotope that can be distinguished analytically from the natural form of Fe. The isotope may be substituted in tracer amounts or as a complete replacement of the naturally occurring Fe. The underlying assumption for the use of intrinsic labelling techniques is that the label is deposited in the same manner and associated with the same constituents as occurs naturally [10]. Extrinsic labelling is both simpler and less expensive, but the isotope added to the food must come into equilibrium with all pools of $\mathrm{Fe}$ in the food. It must behave nutritionally in a manner entirely analogous to the intrinsic $\mathrm{Fe}[17]$. In piglets, ${ }^{59} \mathrm{Fe}$ retention from intrinsically labelled milk proved to be considerably higher than from extrinsically labelled milk. Therefore, the extrinsic tag method was not considered to be valid for studies on Fe absorption from sow's milk [18]. However, several other studies demonstrated that the radioactive Fe added to a food item of vegetable origin just before it was eaten was absorbed to the same extent as that of endogenous dietary Fe [19]. This also applies to stable isotopes, although the quantities required for measurement of absorption are much higher than those used in radioisotope studies, and may have an effect on dietary $\mathrm{Fe}$ itself [11]. In rats, Fe retention from extrinsically ${ }^{58} \mathrm{Fe}$ - and ${ }^{59} \mathrm{Fe}$-labelled baker's yeast was higher than from intrinsically ${ }^{57} \mathrm{Fe}$-labelled yeast. However, the observed differences in apparent absorption were not of sufficient magnitude to invalidate the use of extrinsic stable isotope labelling [20]. Barrett et al [21] compared dietary Fe absorption in women as measured by extrinsic stable Fe with extrinsic radioisotope labels in reflecting intrinsic food Fe absorption, and concluded that the two extrinsic labels were equally valid.

\section{Kinetics of iron}

With certain exceptions, all non-haem Fe in a meal exchanges with a common pool 
of non-haem Fe, and it is from this pool that absorption takes place [22]. Absorption can vary from less than $1 \%$ to almost $100 \%$ depending on Fe status of the subject and meal composition [23], but generally a large proportion of dietary Fe will be excreted with the faeces. Varying fractions of Fe consumed on a specific day are not absorbed and are eliminated from the body via the gastrointestinal tract over a period of several days. Complete elimination of unabsorbed Fe usually takes 6 to $12 \mathrm{~d}$, but shorter or longer periods are occasionally reported [24]. The number of days varies significantly with bowel motility [25], and may be influenced by diet composition [9].

Uptake and absorption capacities are represented by the simultaneous functioning of two pathways: a saturable pathway for uptake of Fe bound to mucin in the intestinal mucous layer and a non-saturable uptake, possibly due to opening of a mucosal barrier to diffusion of unbound $\mathrm{Fe}$ [26]. Saturated mucosal cells are replaced by unsaturated ones, causing the entire lining of the human small intestine to be replaced within 5 to $6 \mathrm{~d}$ [27]. In rats, mucosal cells are renewed every $3 \mathrm{~d}$. Therefore, when $\mathrm{Fe}$ was supplemented every $3 \mathrm{~d}$ instead of daily, a better efficiency of $\mathrm{Fe}$ absorption was found in rats [28]. Also in human subjects a blocking effect on $\mathrm{Fe}$ uptake and absorption capacities seems to be present. Fairweather-Tait \& Minski [29] demonstrated that a $50 \mathrm{mg} \mathrm{Fe}$ load, given $18 \mathrm{~h}$ before ingestion of ${ }^{58} \mathrm{Fe}$-labelled $\mathrm{FeSO}_{4}$, significantly reduced $\mathrm{Fe}$ absorption the next day from $35.4 \%$ to $29.0 \%$. This stresses the importance of strict dietary control during $\mathrm{Fe}$ absorption studies to eliminate biased results.

Fe is distributed within the body via plasma [19]. A human subject with a 5 litre blood volume has about $2.5 \mathrm{~g}$ of the $4 \mathrm{~g}$ of total body Fe incorporated into haemoglobin. Enrichment of the isotope will be found predominantly in erythrocytes formed in close temporal proximity to dosing with the isotope [30]. Therefore, between 14 to $70 \mathrm{~d}$ after isotope administration no further increase has been found in proportion of the isotope dose incorporated into erythrocytes [30-33]. Fe is removed from the haem complex and reutilized a few times for newly formed haem before it is excreted. As the biological half-life of $\mathrm{Fe}$ is about 5.9 years in men and 3.8 years in menstruating women, a biological isotope effect could be present [33]. In adult 
subjects, at least one year is required for an Fe label incorporated into erythrocytes to become equilibrated between erythrocytes and storage sites [19]. Therefore, baseline values can be elevated due to prior isotope absorption tests [34].

The majority of pathological states, leading to an abnormally low erythrocyte incorporation are readily recognized by analysing $\mathrm{Fe}$ status-related blood parameters [33]. In healthy subjects, variation in red cell incorporation of absorbed $\mathrm{Fe}$ is low as compared to variation in $\mathrm{Fe}$ absorption [19]. However, variation in erythrocyte incorporation directly influences the test results on absorption. Therefore, it is necessary to obtain a value for erythrocyte incorporation. How to obtain these values is described bellow.

The methods using isotopes to measure Fe absorption are based on the kinetics of Fe. Fe isotopes are detected in faeces, plasma or erythrocytes, and the methods are called faecal monitoring, plasma Fe appearance test and incorporation of Fe into erythrocytes respectively.

\section{Faecal monitoring}

Using isotopes, absorption can be determined from the disappearance of the isotope during intestinal passage, calculated as the difference between intake and faecal output. The advantage of this technique is that there is only a limited effect of intestinal re-excretion of Fe [9]. Janghorbani et al [25] estimated the maximum cumulative re-entry of the absorbed dose into the intestinal tract to be not higher than $10 \%$ of the absorbed dose during the 2 weeks after administration. According to Hashimoto et al [35], endogenous excretion of Fe (caused by desquamated cells) does not disguise Fe absorption. However, Björn-Rasmussen et al [36] observed several times basal loss of ingested Fe due to excretion of a variable fraction of the Fe which was absorbed but not incorporated into erythrocytes.

Two critical drawbacks of faecal monitoring for absorption determinations are in obtaining a complete collection of unabsorbed isotopes and sample inhomogeneity. Incomplete stool collections probably caused the discrepancy between the faecal monitoring technique and whole-body counting found by Lunn et al [37]. To ensure complete collection of unabsorbed isotopes and to identify faecal samples in relation 
to dietary intake, non-absorbable substances can be used as faecal markers [9]. The difference found between the fraction of ${ }^{58} \mathrm{Fe}$ absorbed based on a marked stool and that based on a 7-day faecal collection (see Table 1) most likely reflects problems associated with obtaining complete faecal collections [31].

Since it is generally impractical to analyse the entire faecal pool, appropriate numbers of sub-samples are to be taken from the faecal pool and analysed for the Fe isotopes of interest. It is imperative in this procedure to ensure thorough mixing of the unabsorbed isotope in the faecal pool to allow of representative sampling [25].

Besides, at very low values of absorption, faecal monitoring is unlikely to be a satisfactory approach for a precise quantification of Fe absorption [25]. The difference between ingested and excreted $\mathrm{Fe}$ is often only 5 to $10 \%$ [19]. Absorption could be increased by dosage or enhancers of absorption. However, the tedious collection of faecal samples remains a disadvantage.

Table 2 Absorption estimated by faecal monitoring

\begin{tabular}{|c|c|c|c|c|}
\hline Ref. & Isotope & $\begin{array}{c}\text { Subjects } \\
\mathrm{n}\end{array}$ & $\begin{array}{c}\text { Absorption } \\
\text { \% } \pm \mathrm{SD}\end{array}$ & Remarks \\
\hline 31 & $s, 0^{2}$ & 11 premature infants & $\begin{array}{l}\text { a. } 41.6 \pm 17.6 \\
\text { b. } 44.4 \pm 18.4\end{array}$ & $\begin{array}{l}\text { a. Based on a } 7 \mathrm{~d} \text { faecal collection } \\
\text { b. Based on marked stool }\end{array}$ \\
\hline 38 & s, o. & $\begin{array}{l}\text { a. } 10 \text { Gambiano } \\
\text { b. } 11 \text { UK o }\end{array}$ & $\begin{array}{l}\text { a. } 2.9 \pm 12.3^{1} \\
\text { b. } 12.7 \pm 3.8^{1}\end{array}$ & Absorption from rice and durango \\
\hline 39 & s,o. & 89 & $\begin{array}{l}\text { a. } 9.0 \\
\text { b. } 8.0\end{array}$ & $\begin{array}{l}\text { a. Diet with milk } \\
\text { b. Diet without milk }\end{array}$ \\
\hline 35 & $s, o^{2}$ & $110^{*}+19$ & $\begin{array}{l}\text { a. } 34.4 \pm 6.1 \\
\text { b. } 15.0 \pm 5.5\end{array}$ & $\begin{array}{l}\text { a. With vitamin } \mathrm{C} \\
\text { b. Without vitamin } \mathrm{C}\end{array}$ \\
\hline
\end{tabular}

s) stable isotope; o) orally administered; ${ }^{1}$ geometric mean $\pm \mathrm{SD} ;{ }^{2}$ ) given without food/between meals.

\section{Plasma/serum appearance}

The plasma appearance test, often called the plasma tolerance test, involves administration of a dose and subsequent measurement of Fe in serum or plasma at intervals of up to 8 hours after administration. The increase in Fe level, usually expressed as the area under the curve above fasting level, is thought to give an 
indication of the absorption of Fe. With isotopes of $\mathrm{Fe}$ it is not necessary to achieve an increase in total plasma levels as the degree of isotope enrichment can be used as an indicator of absorption [9]. The area under the plasma appearance curve for up to $8 \mathrm{~h}$ after oral radioactive $\mathrm{Fe}$ administration shows a high correlation $(\mathrm{r}=0.97)$ with ${ }^{59} \mathrm{Fe}$ whole-body counting [40]. Kaltwasser and co-workers have compared estimates for bioavailability of Fe from a 'slow-release' and a 'quick-release' preparation in phlebotomized men. Measurements were made of erythrocyte utilization of orally administered ${ }^{54} \mathrm{Fe}$ and plasma $\mathrm{Fe}$ appearance curves for up to $8 \mathrm{~h}$. Although serum ferritin- and, haemoglobin concentrations and the mean utilization of the Fe by erythrocytes were virtually identical for the two preparations, they differed markedly with respect to the plasma Fe appearance curves but only a non-significant difference in mean area under the curves was observed. Therefore, comparing the bioavailability of two Fe preparations with different release rates by using the plasma Fe appearance curves for up to $8 \mathrm{~h}$ seems to be inadequate [41].

In these studies an isotope has been given only arally. If one isotope is used no quantitative data for $\mathrm{Fe}$ absorption can be obtained with a plasma appearance test, because plasma enrichment depends both on the rate of absorption and the plasma clearance rate [9]. To determine the plasma clearance rate, a second isotope should be administered intravenously simultaneously with the oral dose. This method was applied by Barrett et al [21], Whittaker et al [42, 43] and Werner et al [44] (see Table 3). Consequently, in patients with Fe deficiency, a higher correlation ( $r=0.99$ ) was found between absorption calculated from double radioactive isotope plasma activity over $4 \mathrm{~h}$ and absorption calculated from whole-body counting [44]. The estimated mean absorption provided by measurement of the post-absorptive serum enrichment of two stable isotopes was only $1.5 \%$ lower ( $95 \%$ confidence interval -5.2 to $2.1 \%$ ) than that yielded by whole-body counting [21] (see Table 3).

However, the validity of application of the plasma Fe appearance test is still questionable when studying the influence of dietary components because they may have a delayed effect on $\mathrm{Fe}$ absorption during the passage of $\mathrm{Fe}$ through the large intestine. For instance, short-chain fatty acids and/or decreased $\mathrm{pH}$ may play an important role in $\mathrm{Fe}$ absorption in the large intestine [45]. Therefore, when 
estimating absorption by means of the plasma Fe appearance curve, interfering factors should be taken into account, such as gastrointestinal transit time and rate of entry of Fe from the gastrointestinal mucosal cell into the blood stream. More blood samples are needed to be able to estimate areas under the curve accurately. This may be a problem when infants are used as subjects.

Table 3 Assessment of $\mathrm{Fe}$ absorption by means of the plasma appearance curve

\begin{tabular}{|c|c|c|c|c|}
\hline Ref. & Isotope & $\begin{array}{c}\text { Subjects } \\
\mathrm{n}\end{array}$ & $\begin{array}{c}\text { Absorption } \\
\% \pm \mathrm{SD}\end{array}$ & Remarks \\
\hline 42 & $\begin{array}{l}\text { s, o. } \\
\text { s, i.v. }\end{array}$ & $4 \%$ & $10.9 \pm 4.2$ & \\
\hline 43 & $\begin{array}{l}\text { s, o. } \\
\text { s, i.v. }\end{array}$ & 9 pregnant? & $\begin{array}{l}\text { a. } 10.5 \pm 7.4 \\
\text { b. } 25.4 \pm 16.4 \\
\text { c. } 38.8 \pm 13.4 \\
\text { d. } 30.5 \pm 15.8\end{array}$ & $\begin{array}{l}\text { a. } 12 \text { weeks of gestation } \\
\text { b. } 24 \text { weeks of gestation } \\
\text { c. } 36 \text { weeks of gestation } \\
\text { d. } 12 \text { weeks post delivery }\end{array}$ \\
\hline 21 & $\begin{array}{l}\text { s, o. } \\
\text { s, i.v. }\end{array}$ & $\begin{array}{l}\text { a. } 68 \\
\text { b. } 49\end{array}$ & $\begin{array}{l}\text { a. } 22.6 \pm 16.4 \\
\text { b. } 16.9 \pm 15.0\end{array}$ & $\begin{array}{l}\text { a. Without food } \\
\text { b. With a meat meal }\end{array}$ \\
\hline 21 & $\begin{array}{l}r, o \\
r, \text { i.v. }\end{array}$ & $\begin{array}{l}\text { a. } 69 \\
\text { b. } 49\end{array}$ & $\begin{array}{l}\text { a. } 24.6 \pm 10.8 \\
\text { b. } 17.8 \pm 13.2\end{array}$ & $\begin{array}{l}\text { a. Without food } \\
\text { b. With a meat meal }\end{array}$ \\
\hline
\end{tabular}

s) stable isotope; r) radioactive isotope; o) orally administered; i.v.) intravenously administered; ') given without food.

\section{Iron incorporation into erythrocytes}

Under the conditions of normal erythropoiesis, a single measurement of the incorporation of $\mathrm{Fe}$ isotopes into erythrocytes, $14 \mathrm{~d}$ after isotope administration, is sufficient for estimation of the absorbed fraction [33]. A high correlation between Fe absorption values obtained by whole-body counting and erythrocyte incorporation of orally administered ${ }^{59} \mathrm{Fe}$ was found by Larsen \& Milman [46]. Also a significant relation exists between ${ }^{58} \mathrm{Fe}$ enrichment of blood and ${ }^{58} \mathrm{Fe}$ absorption calculated as the difference between intake and faecal excretion [29].

Erythrocyte incorporation of $\mathrm{Fe}$, when expressed as percentage of dose ingested, cannot be equated with Fe absorption since it is actually a measure of the two 
unknowns: amount of label absorbed and amount of 'absorbed' label incorporated into the erythrocyte [47]. Ehrenkranz et al [31] measured in 11 premature infants the incorporation of ${ }^{58} \mathrm{Fe}$ into erythrocytes (Table 4). An enrichment of orally administered ${ }^{58} \mathrm{Fe}$ into erythrocytes by $12.0 \%$ would result in an absorption of $41.8 \%$ when corrected for the incorporation of absorbed ${ }^{58} \mathrm{Fe}(28.7 \%)$. This is equal to the absorption measured by faecal isotope balance (see Table 1). To obtain an experimental value for the individual erythrocyte incorporation a blood sample should be taken before and $14 \mathrm{~d}$ after dose administration, and the method of faecal monitoring [31] or whole-body counting [46] should be performed in addition. The latter implies the use of radioactive isotopes. It is also possible to use the fraction of intravenously administered isotope present in circulating erythrocytes as a reference for absorbed $\mathrm{Fe}$ (from the orally administered dose) incorporated into the circulating erythrocytes [48]. This is called the double-isotope technique, which was first applied by Saylor and Finch [49] in rats using two radioactive isotopes. Lunn et al [37] showed a high correlation between $\mathrm{Fe}$ absorption measured by whole-body counting and the double-isotope technique $(r=0.987$ : $Y=1.02-2.41 \mathrm{X})$ in 16 patients widely varying in Fe status.

Werner et al [44] compared several techniques for assessing Fe absorption intraindividually. They concluded that measurement of the incorporation of one single radioactive isotope into erythrocytes is a reliable approach to estimate absorption only in Fe deficiency, when the fraction of radio-Fe utilized by erythrocytes is near $100 \%$. The double radioactive isotope method and the technique applying wholebody counting yielded almost identical values.

Another advantage of the double-isotope technique is that one can minimize the effect of errors in the calculation of total Fe mass by using the ratio of the two isotopes [50]. Using two isotopes, the absorption formula does not have to include this Fe mass.

In estimating the absorption of $\mathrm{Fe}$ based on $\mathrm{Fe}$ utilization by erythrocytes, a rather large subject-to-subject variation is found in incorporation of absorbed Fe, especially in infants (Table 4). Probably, variation in incorporation, within subjects with constant Fe stores, is relatively small, since in healthy subjects erythrocyte utilization 
of Fe does not appear to vary despite fluctuating plasma Fe values at the time of measurement [51]. Therefore, it may be sufficient to obtain only one experimental value for individual erythrocyte incorporation when paired comparisons are included in the study design.

Table 4 Absorption from test meals estimated by means of Fe utilization by erythrocytes

\begin{tabular}{|c|c|c|c|c|c|}
\hline Ref. & $\begin{array}{l}\text { Iso- } \\
\text { tope }\end{array}$ & $\begin{array}{l}\text { Subjects } \\
\mathrm{n}\end{array}$ & $\begin{array}{c}\% \text { Incorpor- } \\
\text { ation } \\
\text { (mean } \pm \text { SD) }\end{array}$ & $\begin{array}{c}\text { Absorption } \\
\%\end{array}$ & Remarks \\
\hline 47 & $\begin{array}{l}\text { s, o. } \\
\text { s, i.v. }\end{array}$ & $\begin{array}{l}6 \text { prema- } \\
\text { ture infants }\end{array}$ & $17.8 \pm 11.3$ & $26.3 \pm 13.0$ & \\
\hline 31 & $\mathrm{~s}, \mathrm{o}$. & $\begin{array}{l}11 \text { prema- } \\
\text { ture infants }\end{array}$ & $28.7 \pm 22.3$ & $\begin{array}{l}12.0 \pm 9.6^{2} \\
41.8^{3}\end{array}$ & \\
\hline 52 & $s, o$ & 10 children & $90^{1}$ & $\begin{array}{l}\text { a. } 5.7 \pm 4.0 \\
\text { b. } 13.7 \pm 6.4\end{array}$ & $\begin{array}{l}\text { a. ferrous-sulphate with milk } \\
\text { b. ferrous-sulphate with apple juice }\end{array}$ \\
\hline 46 & $\mathrm{r}, \mathrm{o}$ & $80^{x}+19 q$ & $92.9 \pm 20.8$ & $11.5 \pm 10.4$ & \\
\hline 50 & $\begin{array}{l}\text { s,o. } \\
\text { s, i.v. }\end{array}$ & 5 우 & $80.8 \pm 9.0$ & $22.1 \pm 8.9$ & \\
\hline 53 & $r, o$. & 119 & $80^{11}$ & $\begin{array}{l}\text { a. } 3.4 \pm 3.7 \\
\text { b. } 3.8 \pm 3.6\end{array}$ & $\begin{array}{l}\text { a. daily Fe supplementation } \\
\text { b. weekly Fe supplementation }\end{array}$ \\
\hline
\end{tabular}

r) radioactive; s) stable; o) orally administered; i.v.) intravenously administered; ${ }^{1}$ ) assumed; ${ }^{2}$ ) not corrected for $\%$ incorporation; ${ }^{3}$ ) corrected absorption $\%$ estimated by using the average values

\section{Discussion regarding absorption studies using isotopes}

Assessing the plasma Fe appearance curve seems to be a promising method, although interfering factors should be taken into account, such as gastrointestinal transit time and rate of entry of Fe from the gastrointestinal mucosal cell into the blood stream. True fractional absorption of Fe fortification from foods can be studied conveniently, less expensively and probably more convincingly by determining ${ }^{58} \mathrm{Fe}$ enrichment of erythrocytes than by ${ }^{58} \mathrm{Fe}$ metabolic balance studies [30]. Besides the advantage of not being affected by excretion and not requiring faecal collection, no determination of blood volume is required when one isotope is administered intravenously and another one orally [49]. 
However, the amount of stable isotopes needed to detect a significant enrichment of the isotopes in erythrocytes is twice as large as the dosage needed for the plasma/serum Fe appearance curve or the faecal monitoring technique. Stable isotopes are expensive and, moreover, the amount of isotopes should not interfere with maintenance of physiological conditions during absorption tests. The amount of stable isotopes needed for obtaining a significant enrichment in erythrocytes of adult women was $10 \mathrm{mg}$ of ${ }^{57} \mathrm{Fe}$ and $0.5 \mathrm{mg}$ of ${ }^{58} \mathrm{Fe}$ for oral and intravenous administration, respectively $[50,54]$. Using the plasma appearance curve to estimate Fe absorption, adult women had to administer an amount of 2.8 or $5 \mathrm{mg}$ of ${ }^{54} \mathrm{Fe}$ orally and $200 \mu \mathrm{g}$ of ${ }^{57} \mathrm{Fe}$ intravenously $[21,42,43]$. Approximately $5 \mathrm{mg}$ of ${ }^{54} \mathrm{Fe}$ was given to female subjects in a study using the faecal monitoring technique [39]. Even a lower dose of about $1 \mathrm{mg}$ of ${ }^{58} \mathrm{Fe}$ appeared to be sufficient in male subjects $[29,38]$.

The enrichment of absorbed stable Fe isotopes will be found predominantly in young erythroid cells formed just after the administration of these isotopes [47]. Erythrocytes live about $110 \mathrm{~d}$, so that each day $0.9 \%$ of circulating erythrocytes are destroyed and replaced. The very young and newly appearing erythroid cells in blood, which are called reticulocytes, represent $1 \%$ of all erythrocytes. Due to the large number of erythroid cells, the stable isotopes incorporated into newly formed erythrocytes will be diluted after entering the circulation. After $14 \mathrm{~d}$ about $80 \%$ of the absorbed $\mathrm{Fe}$ is incorporated into erythrocytes. After $3.5 \mathrm{~d}$, half of this amount will be present in the circulating red cell mass [19]. In a first-stage study (see Chapter 3) executed in our laboratory, a rather high enrichment (ca. 35\%) of the intravenously administered ${ }^{58} \mathrm{Fe}$ was found in cell fractions isolated from blood containing $10 \%$ reticulocytes collected 3 to $8 \mathrm{~d}$ after isotope administration. The red cells were fractionated by discontinuous density gradient. In whole-blood collected $14 \mathrm{~d}$ after intravenous administration only $6 \%$ enrichment was found. Therefore, it should be possible to obtain a higher isotope enrichment with a lower dose of stable isotopes, by isolating cell fractions containing a high concentration of reticulocytes. On the basis of our preliminary results we expect to be able to measure Fe absorption accurately with at least three- to four-fold lower doses of stable $\mathrm{Fe}$ when stable isotope enrichment is measured in reticulocyte-rich erythrocyte fractions. 


\section{References}

1 Yip R. Iron deficiency: contemporary scientific issues and international programmatic approaches. $J$ Nutr 1994;124:1479S-1490S.

2 Monsen ER. Iron nutrition and absorption: dietary factors which impact iron bioavailability. $J$ Am Diet Assoc 1988;88:786-790.

3 Craig WJ. Iron status of vegetarians. Am J Clin Nutr 1994;59:1233S-1237S.

4 Hazell T. Minerals in foods: dietary sources, chemical forms, interactions, biovailability. In: World review of nutrition and dietetics. Minerals in food and nutritional topics. Bourne GH, ed. Basel: Karger, 1985:45-63.

5 Van Dokkum W. Significance of iron bioavailability for iron recommendations. Biol Trace Elem Res 1992;35:1-11.

6. Sayers MH, English G \& Finch C. Capacity of the store-regulator in maintaining iron balance. Am J Hematol 1994;47:194-197.

7 Rucker BR, Lönnerdal B \& Keen CL. Intestinal absorption of nutritionally important trace elements. In: Physiology of the Gastrointestinal Tract. 3rd edit. Johnson LR, ed. New York: Raven Press, 1994:2183-2202.

8 Davidsson L. Minerals and trace elements in infant nutrition. Acta Paediatr Suppl 1994:395:38-42.

9 Sandström B, Fairweather-Tait S, Hurrell R \& Van Dokkum W. Methods for studying mineral and trace element absorption in humans using stable isotopes. Nutr Res Rev 1993;6:71-95.

10 Weaver CM. Intrinsic mineral labeling of edible plants: methods and uses. Crit Rev Food Sci Nutr 1985;23:75-101.

11 Fairweather-Tait SJ. Iron in food and its availability. Acta Paediatr Scand Suppl 1989;361:12-20.

12 Woodhead JC, Drulis JM, Rogers RR, Ziegler EE, Stumbo PJ, Janghorbani M, Ting BT \& Fomon SJ. Use of the stable isotope, ${ }^{58} \mathrm{Fe}$, for determining availability of nonheme iron in meals. Pediatr Res 1988;23:495-499.

13 Kastenmayer P, Davidsson L, Galan P, Cherouvrier F, Hercberg S \& Hurrell RF. A double stable isotope technique for measuring iron absorption in infants. Br J Nutr 1994;71:411-424.

14 Abrams SA, Wen J, O'Brien KO, Stuff JE \& Liang LK. Application of magnetic sector thermal ionization mass spectrometry to studies of erythrocyte iron incorporation in small children. Biol Mass Spectrom 1994;23:771-775.

15 Fairweather-Tait S, Fox T, Wharf SG \& Eagles J. The bioavailability of iron in different weaning foods and the enhancing effect of a fruit drink containing ascorbic acid. Pediatr Res 1995;37:389-394.

16 Turnlund JR. The use of stable isotopes in mineral nutrition research. J Nutr 1989;119:7-14.

17 O'Dell BL. Bioavailability of and interactions among trace elements. In: Trace Elements in Nutrition of Children. Chandra RK, ed. New York: Nestlé Nutrition, Vevey/Raven Press, 1985:41-62.

18 Gislason J, Jones B, Lönnerdal B \& Hambraeus L. Iron absorption differs in piglets fed extrinsically and intrinsically 59Fe-labeled sow's milk. J Nutr 1992;122:1287-1292. 
19) Bothwell TH, Charlton RW, Cook JD \& Finch CA. Iron metabolism in man. London: Blackwell Scientific Publications, 1979.

20 Boza JJ, Fox TE, Eagles J, Wilson PD \& Fairweather-Tait. SJ. The validity of extrinsic stable isotopic labeling for mineral absorption studies in rats. $J$ Nutr 1995;125:1611-1616.

21 Barrett JF, Whittaker PG, Fenwick JD, Williams JG \& Lind T. Comparison of stable isotopes and radioisotopes in the measurement of iron absorption in healthy women. Clin Sci $1994 ; 87: 91-95$.

22 Bothwell TH. Overview and mechanisms of iron regulation. Nutr Rev 1995;53:237-245.

23 Hurrell RF, Davidsson L \& Kastenmayer P. Stable isotope techniques to measure mineral and trace element absorption in man. In: Bioavailability 193. Nutritional, chemical and food processing implications of nutrient availability. Schlemmer U, ed. Karlsruhe: Bundesforschungsanstalt für Ernährung, 1993:223-232.

24 Turnlund JR. Bioavailability of dietary minerals to humans: the stable isotope approach. Crit Rev Food Sci Nutr 1991;30:387-396.

25 Janghorbani M, Ting BT \& Young VR. Absorption of iron in young men studied by monitoring excretion of a stable iron isotope ( ${ }^{58} \mathrm{Fe}$ ) in feces. $J$ Nutr $1980 ; 110: 2190-2197$.

26 Carpenter CE \&. Ummadi M. Iron status alters the adsorption, uptake,and absorption capacities of rat duodenum for ferrous and ferric iron. Nutr Res 1995;15:1129-1138.

27 Schauf CL, Moffett DF \& Moffett SB. Gastrointestinal organization, motility and secretion. In: Human Physiology: Foundation \& Frontiers. Allen D, ed. St. Louis: Times Mirror/Mosby College Publishing, 1990:532-561.

28 Viteri $\mathbb{F E}$, Liu X, Tolomei $\mathrm{K} \&$ Martin A. True absorption and retention of supplemental iron is more efficient when iron is administered every three days rather than daily to iron-normal and iron-deficient rats. $J$ Nutr $1995 ; 125 ; 82-91$.

29 Fairweather-Tait SJ \& Minski MJ. Studies on iron availability in man, using stable isotope techniques. Br I Nutr 1986;55:279-285.

30 Fomon SJ, Janghorbami M, Ting BT, Ziegler EE, Rogers RR, Nelson SE, Ostedgaard LS \& Edwards BB. Erythrocyte incorporation of ingested 58-iron by infants. Pediatr Res $1988 ; 24: 20-24$.

31 Ehrenkranz RA, Gettner PA, Nelli CM, Sherwonit EA, Williams JE, Pearson HA, Ting BT \& Janghorbani M. Iron absorption and incorporation into red blood cells by very low birtli weight infants: studies with the stable isotope ${ }^{58} \mathrm{Fe} . J$ Pediatr Gastroenterol Nutr $1992 ; 15: 270-278$.

32 Hansen C, Werner E \& Kaltwasser JP. Measurement of iron bioavailability by means of stable ${ }^{54} \mathrm{Fe}$ and mass spectrometry. Phys Med Biol 1992;37:1349-1357.

33 Lehmann WD, Fischer R \& Heinrich HC. Iron absorption in man calculated from erythrocyte incorporation of the stable isotope iron-54 determined by fast atom bombardment mass spectrometry. Anal Blochem 1988;172:151-159.

34 Woodhead JC, Drulis JM. Nelson SE, Janghorbani M \& Fomon SJ. Gender-related differences in iron absorption by preadolescent children. Pediatr Res 1991;29:435-439.

35 Hashimoto F, Fujii $Y$, Toba M, Okamatsu H \& Kohri H. Determination of absorption and endogenous excretion of iron in man by monitoring fecal excretion of a stable iron isotope ( $\left.{ }^{5} \mathrm{Fe}\right)$. I Nutr Sci Vitaminol 1992;38:435-449. 
36 Björn-Rasmussen E, Carneskog I \& Cederblad A. Losses of ingested iron temporarily retained in the gastrointestinal tract. A possible auxiliary mechanism for regulation of iron absorption. Scand J Haematol 1980;25:124-126.

37 Lunn JA, Richmond J, Simpson JD, Leask JD \& Tothill P. Comparison between three radioisotope methods for measuring iron absorption. $\mathrm{Br}$ Med $J$ 1967;3:331-333.

38 Fairweather-Tait SJ, Minski MJ \& Singh J. Nonradioisotopic method for measuring iron absorption from a Gambian meal. Am J Clin Nutr 1987;46:844-848.

39 Turnlund JR, Smith RG, Kretsch MJ, Keyes WR \& Shah AG. Milk's effect on the bioavailability of iron from cereal-based diets in young women by use of in vitro and in vivo methods. Am J Clin Nutr 1990;52:373-378.

40 Kaltwasser JP, Werner E \& Niechzial M. Bioavailability and therapeutic efficacy of bivalent and trivalent iron preperations. Drug Res 1987;37-1:122-129.

41 Kaltwasser JP, Hansen C, Oebike Y \& Werner E. Assessment of iron availability using stable 54Fe. Eur J Clin Invest 1991;21:436-442.

42 Whittaker PG, Lind T, Williams JG \& Gray AL. Inductively coupled plasma mass spectrometric determination of the absorption of iron in normal women. Analyst 1989;1 14:675-678.

43 Whittaker PG, Lind T \& Williams JG. Iron absorption during normal human pregnancy: a study using stable isotopes. Br J Nutr 1991;65:457-463.

44 Werner E, Roth P, Hansen C \& Kaltwasser JP. Comparative evaluation of intestinal iron absorption by four different methods in man. In: Structure and function of iron storage and transport proteins. Urushizaki I, et al, eds. Elsevier Science Publishers BV, 1983:403-408.

45 Ebihara K, Okano J \& Miyata T. Comparison of ferrous and ferric iron bioavailability following rat cecal infusion. Nutr Res 1994;14:221-228.

46 Larsen L \& Milman N. Normal iron absorption determined by means of whole body counting and red cell incorporation of 59Fe. Acta Med Scand 1975;198:271-274.

47 Zlotkin SH, Lay DM, Kjarsgaard J \& Longley T. Determination of iron absorption using erythrocyte iron incorporation of two stable isotopes of iron $\left({ }^{57} \mathrm{Fe}\right.$ and $\left.{ }^{58} \mathrm{Fe}\right)$ in wery low birthweight premature infants. J Pediatr Gastroenterol Nutr 1995;21:190-199.

48 Janghorbani M, Ting BT \& Fomon SJ. Erythrocyte incorporation of ingested stable isotope of iron $\left({ }^{58} \mathrm{Fe}\right)$. Am J Hematol 1.986;21:277-288.

49 Saylor L \& Finch CA. Determination of iron absorption using two isotopes of iron. Am J Physiol 1953;172:372-376.

50 Barrett JF, Whittaker PG, Williams JG \& Lind T. Absorption of non-haem iron in normal women measured by the incorporation of two stable isotopes into erythrocytes. Clin Sci 1992;83:213-219.

51 Skarberg K, Eng M, Huebers H, Marsaglia G \& Finch C. Plasma radioiron kinetics in man: explanation for the effect of plasma iron concentration. Proc Nall Acad Sci U S A 1978;75:1559-1561.

52 Abrams SA, O'Brien KO, Wen J, Liang LK \& Stuff JE. Absorption by 1-year-old children of an iron supplement given with cow's milk or juice. Pediatr Res 1996;39:171-175.

53 Cook JD \& Reddy MB. Efficancy of weekly compared with daily iron supplementation. Am J Clin Nutr 1995;62:117-120. 
Chapter 2

54 Whittaker PG, Barrett JFR \& Williams JG. Precise determination of iron isotope ratios in whole blood using inductively coupled plasma mass spectrometry. I Anal At Spectrom $1992 ; 7: 109-113$. 


\section{3}

\section{Enrichment of ${ }^{57} \mathrm{Fe}$ and ${ }^{58} \mathrm{Fe}$ in young erythroid cells of men, separated by a Percoll density gradient}

Ellen GHM van den Heuvel, Gertjan Schaafsma, Theo Muijs, Joop B Luten, Hillie Pellegrom, Joop P Bruyntjes, Steven Spanhaak and Wim van Dokkum

\section{Abstract}

Iron absorption can be measured by the incorporation of stable iron isotopes into erythrocytes. Because a relatively high dose of stable isotopes is needed to achieve a sufficient enrichment in erythrocytes, we have tested whether a higher enrichment can be achieved by isolating young erythroid cells and thus whether it is possible to reduce the required dose of stable isotopes.

Four healthy young men were administered orally $20 \mathrm{mg}$ enriched ${ }^{57} \mathrm{Fe}$ and intravenously $237.5 \mu \mathrm{g}$ enriched ${ }^{58} \mathrm{Fe}$. Blood was drawn before and on Days 3, 4, 5 , $6,7,8$ and 14 after administration of the isotopes. Using a density separation method, the very young erythrocytes were isolated in which isotope enrichment was measured.

A significant enrichment of ${ }^{58} \mathrm{Fe}$ of ca. $35 \%$ was found in the cell fractions from Day 5 until Day 8. At Day 14 the enrichment in the cell fractions was still apparent but had decreased to $25 \%$. No significant enrichment was found in whole-blood. Considering the high enrichment of ${ }^{58} \mathrm{Fe}$, a high enrichment of the orally administered ${ }^{57} \mathrm{Fe}$ would also be expected in the isolated young erythroid cells. However, no enrichment was found in the ${ }^{57} \mathrm{Fe} /{ }^{56} \mathrm{Fe}$ ratio. The order in which the 
stable isotopes in this experiment were administered, might have interfered with the absorption of the oral isotope.

The isolation of young erythroid cells using a density separation method, can be considered as promising for obtaining a high enrichment of stable isotopes.

\section{Introduction}

Absorption of non-haem iron (Fe) can be measured by the incorporation of a simultaneous intravenously (i.v.) and orally administered stable Fe isotope into erythrocytes of blood sampled two weeks after administration [1, 2]. Until recently this dual stable isotope technique with physiological doses of stable isotopes has been executed only in female subjects who have a smaller blood volume [3] and show a higher Fe absorption than men [4]. Therefore, a much higher dose of stable isotopes and optimum absorption conditions would be needed in men to obtain sufficient enrichment levels of the isotope ratio in erythrocytes.

Within 3.5 d half of the $80 \%$ [5] to $92.9 \%$ newly absorbed Fe [6] is present in the circulating red cell mass $14 \mathrm{~d}$ after administration [5]. This high recovery of administered $\mathrm{Fe}$ isotopes in the first days is caused by the polychromatophil and acidophil erythroblasts, the intramedullary stages of development of the erythrocytes, which represent the highest utilization of $\mathrm{Fe}$ in the bone marrow. The time interval between uptake of Fe by these particular cells and their entry into the circulation as reticulocytes lies between 60 to $85 \mathrm{~h}[7]$.

The aim of the present study was to isolate cell fractions with a large amount of young erythroid cells of blood taken just a few days after the administration of ${ }^{57} \mathrm{Fe}$ orally and ${ }^{58} \mathrm{Fe}$ intravenous $\Downarrow$ y. In that way we could determine whether this isolation results in a higher isotope enrichment, due to the reduced amount of not enriched older erythroid cells.

\section{Methods}

Study protocol

Four healthy and non-smoking men aged 26, 30,37 and 47 volunteered in the study. The study was approved by the TNO external Medical Ethics Committee and all 
subjects gave their informed consent.

The stable isotopes were obtained from Intersales Holland BV. A solution of Fe enriched in ${ }^{57} \mathrm{Fe}\left(0 \%{ }^{54} \mathrm{Fe} ; 0.4 \%{ }^{56} \mathrm{Fe} ; 95.6 \%{ }^{57} \mathrm{Fe} ; 4.0 \%{ }^{58} \mathrm{Fe}\right)$ and a solution of $\mathrm{Fe}$ enriched in ${ }^{58} \mathrm{Fe}\left(0.01 \%{ }^{54} \mathrm{Fe} ; 0.16 \%{ }^{56} \mathrm{Fe} ; 6.7 \%{ }^{57} \mathrm{Fe} ; 93.13 \%{ }^{58} \mathrm{Fe}\right)$ were prepared according to the method of Barrett et al [1].

The solution of ${ }^{57} \mathrm{Fe}$ was divided into four portions. Each portion (containing $5 \mathrm{mg}$ enriched ${ }^{57} \mathrm{Fe}$ ) was added to $50 \mathrm{ml}$ of orange juice which was administered directly after breakfast and lunch on two consecutive days (Days 0 and 1). These meals consisted of dressed white bread and a glass of milk. No coffee or tea was allowed until two hours after lunch. The second day before the oral administration $2 \mathrm{ml}$ of the ${ }^{58} \mathrm{Fe}$ solution (containing $237.5 \mu \mathrm{g}$ enriched ${ }^{58} \mathrm{Fe}$ ) was injected simultaneously with $10 \mathrm{ml}$ saline via a three-way tap. The opening used for the injection of the intravenous solution was flushed clean by another $10 \mathrm{ml}$ of saline. Both the oral and the intravenous dose were weighed carefully. In order to keep total Fe intake constant, the subjects consumed a low-iron diet during the two days of dose administration. This diet contained of $6.4 \mathrm{mg}$ Fe as computed from the Dutch Food Composition Table [8].

Before administration of the stable isotopes (Day 0 ) and on Days $3,4,5,6,7,8$ and $14,10 \mathrm{ml}$ of blood was sampled and transferred into a lithium heparin tube. Erythroid cells of the daily blood samples were separated by a Percoll density gradient to isolate reticulocyte-enriched cell fractions [9]. Enrichment of reticulocytes was determined by means of thiazole orange labelling of reticulocytes in combination with flow cytometric analysis. Both the reticulocyte-enriched fractions and the whole-blood samples of Days 0 and 14 were prepared for the inductively coupled plasma mass spectrometric (ICP-MS) analyses of the stable isotope ratios.

\section{Density separation}

To separate young and old erythrocytes, red cells were fractionated by discontinuous density gradient using Percoll (Pharmacia Biotech Benelux B.V.).

A BSA-HEPES-buffered solution and a BSA-Percoll-HEPES-buffered solution, as 
described by Salvo et al [9], were mixed to form six solutions with a final Percoll concentration of $57 \%, 58.5 \%, 60 \%, 61.5 \%, 63 \%$ and $64.5 \%$. Discontinuous six-layer gradients were prepared by superimposing $6 \mathrm{ml}$ of each Percoll solution in a $50 \mathrm{ml}$ conical tube (Becton Dickinson Labware, Lincoln Park, NJ). The optimum conditions were obtained when a quantity of $4 \mathrm{ml}$ of whole-blood was layered on top of the gradient. Centrifugation was carried out at $1000 \times \mathrm{g}$ for $10 \mathrm{~min}$ at $20^{\circ} \mathrm{C}$ [9]. For each volunteer duplicate blood samples of $4 \mathrm{ml}$ were processed daily.

Cell fractions were obtained with a pasteur pipette and washed once with HEPESbuffered isotonic saline, followed by centrifugation at $300 \mathrm{xg}$ for $10 \mathrm{~min}$ at $4^{\circ} \mathrm{C}$ in order to remove Percoll.

\section{Determination of erythroid cells}

To $30 \mu \mathrm{l}$ of each cell fraction or $2.5 \mu \mathrm{l}$ of whole-blood $0.5 \mathrm{ml}$ thiazole orange (Reticount) was added. After $30 \mathrm{~min}$ incubation in the dark the percentage of reticulocytes was measured with an Epics Elite Flowcytometer (Coulter) on the basis of their fluorescence signals at $525 \mathrm{~nm}$. Leucocytes and platelets were discriminated from erythrocytes. The percentage of reticulocytes gave an impression of the efficiency of the separation.

About $2.5 \mathrm{ml}$ of each remaining part of the six cell fractions was resuspended in 0.5 ml HEPES-buffered isotonic saline. Of these mixtures the recovery of the total number of erythrocytes was determined with a cell counter (Charles Goffin, CC180). The total amount of erythrocytes gave an impression of the amount of Fe which was estimated at $0.11 \mathrm{pg}$ per erythrocyte. Each cell fraction obtained from the duplicate of whole-blood that consisted of the highest reticulocyte percentage and amount of Fe was selected and pooled per subject for analysis by ICP-MS. Every day, the same cell fractions were pooled per subject.

\section{ICP-MS}

The cell fractions and blood samples were prepared for the ICP-MS analysis of the stable isotope ratios ${ }^{57} \mathrm{Fe} /{ }^{56} \mathrm{Fe}$ and ${ }^{58} \mathrm{Fe} /{ }^{56} \mathrm{Fe}[10]$. After destruction of the samples in a Teflon tube with concentrated nitric acid, the $\mathrm{pH}$ was adjusted to $3.0 \pm 0.5$ with 
ammonia. Fe was isolated by selective extraction with $1 \%$ sodium diethyldithiocarbamate (trihydrate) into $\mathrm{CCl}_{4}$. The water layer was rejected. The carbon tetrachoride layer was then left overnight with $10-20 \mathrm{ml} 1.4 \mathrm{~N} \mathrm{HNO}_{3}$. The $\mathrm{HNO}_{3}$ layer was used for the ICP-MS (Perkin Elmer Sciex, Elan 500) measurement. All measurements were carried out in isotope ratio peak hopping mode. The ICP-MS was operated in the high resolution mode to provide maximal accuracy. Typical conditions for operations were: plasma power $1.2 \mathrm{~kW}$, reflected power $<5 \mathrm{~W}$, coolant Ar-flow rate $18 \mathrm{l} / \mathrm{min}$, dwell time $20 \mathrm{msec}, 1$ measurement per peak, 10 repeats per integration, total measuring time $270 \mathrm{sec}$. ICP-MS plasma was optimized to reduce the possible molecular interference at $\mathrm{m} / \mathrm{z} 56$ of $\mathrm{ArO}^{+}[11]$.

The $\mathrm{Fe}$ concentration in the $\mathrm{HNO}_{3}$ solution was measured with atomic absorption spectrometry. If necessary, the solution was diluted in order to adjust the Fe concentration to ca. $1.0 \mu \mathrm{g} / \mathrm{ml}$ to avoid saturation of the detection system. However, in most cases the apparent ${ }^{56} \mathrm{Fe}$ concentration was $<10 \mathrm{ng} / \mathrm{ml}$, which was too low $(<1.0 \mu \mathrm{g} / \mathrm{ml})$ to produce a signal with a high precision. Therefore, it was necessary to combine some separated cell fractions to obtain a total Fe mass of at least $30 \mu \mathrm{g}$ to be destructed and isolated.

During each ICP-MS run, solutions of an Fe standard $(1.0 \mu \mathrm{g} / \mathrm{ml})$, blank, $\mathrm{HNO}_{3}$ and a sample were analysed for the isotope ratios ${ }^{57} \mathrm{Fe} /{ }^{56} \mathrm{Fe}$ and ${ }^{58} \mathrm{Fe} /{ }^{56} \mathrm{Fe}$. The results of the samples were corrected for the small interference of $\mathrm{ArO}^{+}$at ${ }^{56} \mathrm{Fe}$. Minor adjustments in bias were made for unknown factors by comparing standards with accepted natural abundances. All samples were measured in duplicate.

Each whole-blood sample was analysed within 1 day to reduce variability. The cell fractions could not be analysed within 1 day. However, according to Whittaker et al [2] one can overcome day-to-day variation in measured natural isotope ratios by running Fe standards every third sample and adjusting for bias, as was done in our study. 


\section{Results}

Dose of stable isotopes

The total dose (oral and i.v.) of ${ }^{57} \mathrm{Fe}$ administered to the subjects varied between $19.38 \mathrm{mg}$ and $19.53 \mathrm{mg}$. The i.v. dose of ${ }^{58} \mathrm{Fe}$ varied between $0.215 \mathrm{mg}$ and 0.228 mg.

\section{Density separation}

For subjects $\mathrm{A}, \mathrm{B}$ and $\mathrm{C}$, a pooled cell fraction was obtained by combining the cell fractions isolated from the $57 \%, 58.5 \%$ and $61.5 \%$ Percoll gradient layers. For subject $\mathrm{D}$, the cell fractions from the $57 \%, 58.5 \%$ and $63 \%$ Percoll layers were combined. The mean percentage of reticulocytes in the pooled cell fraction was ca. 10.4 (SD 2.4)\%, while in whole-blood a percentage of 1.0 (SD 0.3)\% was measured. The percentages of reticulocytes in each isolated cell fraction are given in Table 1.

Table 1 The average percentage of reticulocytes in the cell fractions obtained from layers of different Percoll concentrations

\begin{tabular}{cccccccccc}
\hline & \multicolumn{10}{c}{ Day } \\
\cline { 2 - 9 } \% percoll & 0 & 3 & 4 & 5 & 6 & 7 & 8 & 14 \\
\hline \multirow{2}{*}{57} & $34.8^{1}$ & 34.7 & 47.4 & 33.7 & 45.1 & 43.6 & 44.6 & 46.8 \\
& $(2.8)$ & $(5.0)$ & $(4.5)$ & $(9.4)$ & $(3.7)$ & $(4.5)$ & $(8.0)$ & $(5.7)$ \\
58.5 & 16.4 & 13.2 & 19.1 & 13.3 & 17.3 & 17.2 & 20.1 & 18.4 \\
& $(2.5)$ & $(2.0)$ & $(2.0)$ & $(4.8)$ & $(2.8)$ & $(2.6)$ & $(3.3)$ & $(1.8)$ \\
61.51 & 8.5 & 5.1 & 6.1 & 4.4 & 5.2 & 5.7 & 5.5 & 5.1 \\
& $(2.6)$ & $(1.2)$ & $(0.6)$ & $(1.3)$ & $(0.5)$ & $(0.3)$ & $(0.4)$ & $(0.7)$ \\
632 & 3.8 & 3.8 & 6 & 2.9 & 4 & 3.8 & 4.4 & 3.4 \\
\hline
\end{tabular}

${ }_{n=3}{ }^{2}{ }^{2}$ in one subject the best combination of cell fractions was $57 \%+58.5 \%+63 \%$ to obtain the highest $\%$ of reticulocytes and sufficient iron to perform the analyses of ICP-MS, therefore n=1.

ICP-MS

Table 2 shows the enrichment of the ${ }^{57} \mathrm{Fe} /{ }^{56} \mathrm{Fe}$ and ${ }^{58} \mathrm{Fe} /{ }^{56} \mathrm{Fe}$ ratios in pooled cell fractions. Due to technical problems the pooled cell fractions of two subjects for 
Days 3 and 4 could not be analysed.

All samples were measured in duplicate. The within-duplicate variation (coefficient of variation; $\mathrm{CV}$ ) of the ${ }^{57} \mathrm{Fe} /{ }^{56} \mathrm{Fe}$ ratio in the cell fractions was $1.7 \%$ and of the ${ }^{58} \mathrm{Fe} /{ }^{56} \mathrm{Fe}$ ratio was $5.1 \%$. In whole-blood the $\mathrm{CV}$ for the ${ }^{57} \mathrm{Fe} /{ }^{56} \mathrm{Fe}$ ratio and the ${ }^{58} \mathrm{Fe} /{ }^{56} \mathrm{Fe}$ ratio was $1.5 \%$ and $6.5 \%$, respectively.

Although the precision of the ${ }^{58} \mathrm{Fe} /{ }^{56} \mathrm{Fe}$ ratio was rather low, a significant enrichment of three times the standard deviation above basal values [12] of $>15.3 \%$ was found in most cell fractions. This enrichment reached a plateau value after $5 \mathrm{~d}$. The highest enrichment of ${ }^{58} \mathrm{Fe}$ was found in the pooled fraction of subject $\mathrm{A}$, in which also the highest absolute amount of reticulocytes was isolated (see Figure 1). No significant enrichment was found in the ${ }^{57} \mathrm{Fe} /{ }^{56} \mathrm{Fe}$ ratio.

Table 2 The percentage enrichment of the ${ }^{57} \mathrm{Fe} /{ }^{56} \mathrm{Fe}$ and ${ }^{58} \mathrm{Fe} /{ }^{56} \mathrm{Fe}$ ratios in pooled cell fractions prepared on several days after administration

\begin{tabular}{llccccccc}
\hline & & \multicolumn{7}{c}{ Day } \\
\cline { 3 - 9 } Ratio & Subject & 3 & 4 & 5 & 6 & 7 & 8 & 14 \\
\hline${ }^{57} \mathrm{Fe} /{ }^{56} \mathrm{Fe}$ & A & - & -2.7 & 0.4 & -4.0 & -1.6 & -0.5 & 4.2 \\
& B & - & -1.3 & -1.7 & 0.5 & -0.9 & 0.2 & -0.9 \\
& $\mathrm{C}$ & 0.7 & - & -4.6 & 2.1 & 3.4 & 2.2 & 0.4 \\
& $\mathrm{D}$ & 4.7 & - & 3.0 & 1.0 & 1.0 & 3.4 & -0.6 \\
& & & & & & & & \\
& Mean & 2.7 & -2.0 & -0.7 & -0.1 & 0.5 & 1.3 & 0.8 \\
\hline${ }^{58} \mathrm{Fe} /{ }^{56} \mathrm{Fe}$ & A & - & 49.2 & 75.4 & 75.9 & 74.9 & 75.4 & 57.2 \\
& B & - & -7.6 & 25.2 & 30.4 & 28.0 & 32.8 & 18.0 \\
& C & 16.9 & - & 19.1 & 21.7 & 21.0 & 20.6 & 16.5 \\
& D & 0 & - & 19.7 & 1.5 .0 & 16.1 & 21.5 & 7.3 \\
& & & & & & & & \\
& Mean & 8.5 & 20.8 & 34.9 & 35.8 & 35.0 & 37.6 & 24.8 \\
\hline
\end{tabular}

Table 3 shows the enrichment of the ${ }^{57} \mathrm{Fe} /{ }^{56} \mathrm{Fe}$ and ${ }^{58} \mathrm{Fe} /{ }^{56} \mathrm{Fe}$ ratios measured in the pooled cell fractions (average of Days 5, 6, 7 and 8) and in whole-blood. As expected, due to the low dose of isotopes the enrichment of ${ }^{58} \mathrm{Fe} /{ }^{56} \mathrm{Fe}$ and ${ }^{57} \mathrm{Fe} /{ }^{56} \mathrm{Fe}$ in 
whole-blood was within the experimental error of the ICP-MS analyses.

Figure 1 Average number of reticulocytes in the cell fractions obtained from layers of differen Percoll concentration.

\section{DS Subject or $=$ Subject 02 a Subject 03 subject 04}

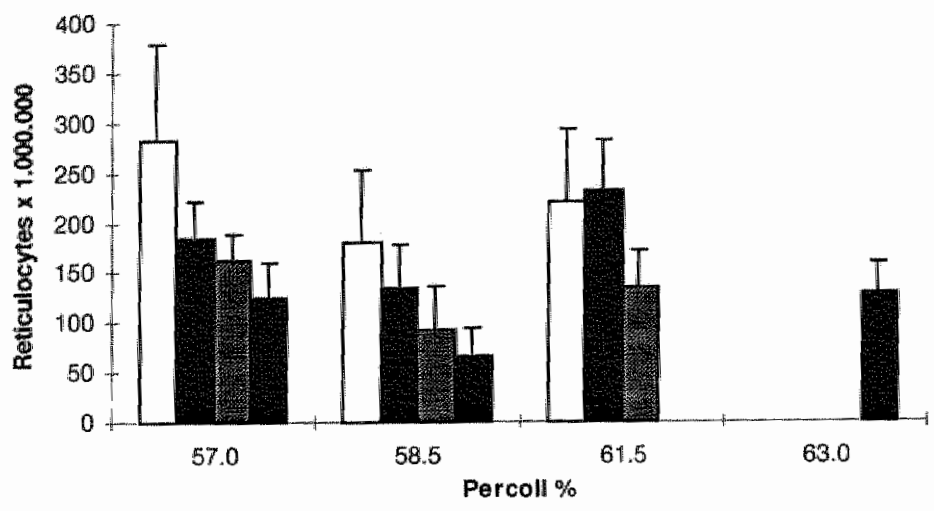

\section{Discussion}

The aim of our study was to verify whether an increased enrichment in isotope ratios can be achieved by isolating erythrocyte fractions containing a relatively large number of young erythroid cells, in which theoretically the administered isotope should have been incorporated at first. The cell fractions were obtained by a density separation technique. With this technique fractions with 15-20\% [13], 20\% [14], 30$40 \%$ [15], 50\% [16] or 70\% [9] of reticulocytes can be separated. Although we were able to separate fractions with a maximum of $47 \%$ reticulocytes, we had to combine some fractions to get the required amount of Fe for ICP-MS analyses. The final combination of two times three fractions contained only $10.4 \%$ reticulocytes. However, the principle behind the separation of the erythrocytes by density is that there is progressive reduction of cell volume during the cell ageing process [17]. As it appear's logical that fractionation according to raising density should yield cells of progressively increasing mean age in consecutive fractions [18], the fractions rich in 
reticulocytes contain also young erythrocytes with just incorporated stable isotopes. If there were only reticulocytes next to a mean population of erythrocytes, the enrichment in ${ }^{58} \mathrm{Fe} /{ }^{56} \mathrm{Fe}$ would not balance at an average of $35 \%$ after $5 \mathrm{~d}$, since all erythroid cells spend only the last $20-35 \mathrm{~h}$ of their development as reticulocytes in the circulating blood [19].

In this study ${ }^{58} \mathrm{Fe} /{ }^{56} \mathrm{Fe}$ reached a plateau after $5 \mathrm{~d}$. Based on an absorption of $5 \%$ for healthy young men and the enrichment of $35 \%$ in the ${ }^{58} \mathrm{Fe} /{ }^{56} \mathrm{Fe}$ ratio in the cell fractions from Day 5 to Day 8 and assuming the same kinetics for ${ }^{57} \mathrm{Fe}$ as for ${ }^{58} \mathrm{Fe}$, the enrichment of ${ }^{57} \mathrm{Fe}$ in the cell fractions should be ca. $17 \%$. However, no significant enrichment was found in the ${ }^{57} \mathrm{Fe} /{ }^{56} \mathrm{Fe}$ ratio, indicating that no measurable absorption took place.

Table 3 The enrichment of ${ }^{57} \mathrm{Fe} /{ }^{56} \mathrm{Fe}$ and ${ }^{58} \mathrm{Fe} /{ }^{56} \mathrm{Fe}$ in whole-blood and in pooled cell fractions (average of Day 5 to Day 8 )

\begin{tabular}{|c|c|c|c|c|}
\hline \multirow[b]{2}{*}{ Subjects } & \multicolumn{2}{|c|}{$\begin{array}{c}\text { Enrichment of }{ }^{57} \mathrm{Fe} /{ }^{56} \mathrm{Fe} \\
(\%)\end{array}$} & \multicolumn{2}{|c|}{$\begin{array}{c}\text { Enrichment of }{ }^{58} \mathrm{Fe} /{ }^{56} \mathrm{Fe} \\
(\%)\end{array}$} \\
\hline & Whole-blood & $\begin{array}{l}\text { Pooled cell } \\
\text { fraction }\end{array}$ & Whole-blood & Pooled cell fraction \\
\hline A & 0.9 & -1.4 & -2.6 & 75.4 \\
\hline B & 1.2 & -0.5 & 8.3 & 29.1 \\
\hline C & 0.4 & 0.8 & 4.3 & 20.6 \\
\hline $\mathrm{D}$ & 2.7 & 2.1 & 11.3 & 18.1 \\
\hline
\end{tabular}

The i.v. dosed ${ }^{58} \mathrm{Fe}$ isotope was given before the administration of the orally administered isotope on the second day, as described by Barrett et al [1], which could have led to a lower absorption of ${ }^{57} \mathrm{Fe}$ during the second day of oral administration. This is confirmed by the lower daily Fe retention in rats given a single i.v. or intraperitoneal dose of Fe, compared with no supplementary i.v. injection $[20,21]$. Probably temporarily, less Fe was retained due to reduced absorption as is indicated by the still somewhat lower true absorption in rats with parenteral dosed $\mathrm{Fe}[21]$. This is also in accord with the 'mucosal block' theory [22] resulting from the 
observation that in rats a single parenteral administration of $\mathrm{Fe}$ significantly increased intestinal tissue $\mathrm{Fe}$ content, which in its turn down-regulated intestinal absorption [23].

Compared with our male subjects, the possible interference of administering ${ }^{58} \mathrm{Fe}$ before ${ }^{57} \mathrm{Fe}$ might not have considerably affected the enrichment of the orally administered isotope in the female subjects of Barrett et al [1], as women absorb a higher proportion of $\mathrm{Fe}$ compared with men. The purpose of the intravenous administration of a second isotope is that one can determine the redistribution of the orally absorbed Fe between erythrocytes or reticulocytes and the rest of the body [1]. Moreover, by analysing both ${ }^{58} \mathrm{Fe}$ and ${ }^{57} \mathrm{Fe}$ in the same pooled cell fraction one can eliminate any variation in age of erythroid cells, by dividing the ${ }^{57} \mathrm{Fe} /{ }^{56} \mathrm{Fe}$ ratio by the ${ }^{58} \mathrm{Fe} /{ }^{56} \mathrm{Fe}$ ratio in the Fe absorption formula described by Barrett et al [1]. This will be important when the high enrichment due to isolation of young erythroid cells would be used to calculate absorption, as at any density gradient level there is a considerable overlap with cells from other cohorts [18], and occasionally minimal amounts of reticulocytes are detected in the two bottom fractions [15, 17, 24].

To reach a significant enrichment of the orally and intravenously administered stable isotopes the required dose for these male subjects with a total amount of circulating Fe in erythrocytes of $3030 \mathrm{mg}$ and an absorption of ca. $5 \%$ should be $75 \mathrm{mg}{ }^{57} \mathrm{Fe}$ and $1 \mathrm{mg}{ }^{58} \mathrm{Fe}$. In this study the subjects were given about $25 \%$ of the required dose and consequently the enrichment of ${ }^{57} \mathrm{Fe}$ and ${ }^{58} \mathrm{Fe}$ in whole-blood sampled $14 \mathrm{~d}$ after dose administration was small and non-significant.

Even if the oral dose in the 'erythrocyte iron incorporation' method, used by Barret et al [1] could be reduced by $50 \%$, for example by the addition of vitamin C [25-27], it is still high and expensive. Therefore, in this study we tested an alternative to the 'erythrocyte iron incorporation' method. By density separation, cell fractions with a maximum of $47 \%$ of reticulocytes were obtained. Compared to whole-blood, in a combination of some of these cell fractions a several times higher enrichment of the ${ }^{58} \mathrm{Fe} /{ }^{56} \mathrm{Fe}$ ratio was measured. In contrast, ${ }^{57} \mathrm{Fe}$ was neither enriched in whole-blood nor in the pooled cell fractions. This could be due to the experimental design in which the intravenous isotope is administered before the orally administered isotope. 
In conclusion, separating young from older erythroid cells clearly leads to a higher enrichment of stable $\mathrm{Fe}$ isotopes. This is a promising observation for future $\mathrm{Fe}$ absorption studies.

\section{References}

1 Barrett JF, Whittaker PG, Williams JG \& Lind T. Absorption of non-haem iron in normal women measured by the incorporation of two stable isotopes into erythrocytes. Clin Sci 1992;83:213-219.

2 Whittaker PG, Barrett JFR \& Williams JG. Precise determination of iron isotope ratios in whole blood using inductively coupled plasma mass spectrometry. $J$ Anal At Spectrom 1992; 7:109-113.

3 Geigy Scientific Tables. 8th edit. Basle: Ciba-Geigy, 1981.

4 Cook JD, Dassenko S \& Skikne BS. Serum transferrin receptor as an index of iron absorption. BrJ Haematol 1990;75:603-609.

5 Bothwell TH, Charlton RW, Cook JD \& Finch CA. Internal iron kinetics. In: Iron metabolism in man. Bothwell TH, Charlton RW, Cook JD, Finch CA, eds. London: Blackwell Scientific Publications, 1979:327-335.

6 Larsen L \& Milman N. Normal iron absorption determined by means of whole body counting and red cell incorporation of ${ }^{59} \mathrm{Fe}$. Acta Med Scand 1975;198:271-274.

7 Najean Y, Dresch C \& Faille A. Recent methods for investigation of erythropoiesis and iron kinetics in man. In: Iron deficiency. Pathogenesis, clinical aspects, therapy. Hallberg L, Harwerth HG, Vanotti A, eds. London: Academic Press, 1970:307-328.

8 Nevo Foundation Editorial Board. Food composition table 1993-1994. The Hague: Krips Repro, 1994.

9 Salvo G, Caprari P, Samoggia P, Mariani G \& Salvati AM. Human erythrocyte separation according to age on a discontinuous "Percoll" density gradient. Clin Chim Acta 1982;122:293-300.

10 Luten JB, Muijs T \& Van Dokkum W. The determination of stable isotope ratio of zinc, copper, iron in faeces and calcium in urine by ICP-MS. In: Bioavailability '93. Nutritional, chemical and food processing implications of nutrient availability. Schlemmer U, ed. Karlsruhe: Bundesforschungsanstalt für Emährung, 1993:161-168.

11 Gray AL \& Williams JG. System optimisation of the effect on polyatomic, oxide and double charged ion response of a commercial inductively coupled plasma mass spectrometry instrument. $J$ Anal At Spectrom 1987;2:599-606.

12 Miller JC \& Miller JN. Errors in instrumental analysis;regression and correlation. In: Statistics for analytical chemistry. 2nd edit. Miller JC, Miller IN, eds. West Sussex: Ellis Horwood Limited, 1988:101-135.

13 Hrusova H, Strunecka A, Piacentini MP, Accorsi A \& Magnani M. Red blood cell age dependent modifications of inositol 1,4,5-trisphosphate. Mech Ageing Dev 1993;67:13-19.

14 Broudy VC, Lin N, Brice M, Nakamoto B \& Papayannopoulou T. Erythropoietin receptor characteristics on primary human erythroid cells. Blood 1991;77:2583-2590. 
15 Micheli V, Sestini S, Rocchigiani M. Pescaglini M \& Ricci C. Significance and relevance of NAS synthesis in human erythrocyte life span. In: Red Blood Cell Ageing. Magnani M, de Flora A, eds. New York: Plenum Press, 1991:139-146.

16 Vettore L, De Matteis MC \& Zampini P. A new density gradient system for the separation of human red blood cells. Am I Hematol 1980;8:291-297.

17 Piomelli S, Lurinsky G \& Wasserman LR. The mechanism of red cell aging. I. Relationship between cell age and specific gravity evaluated by ultracentrifugation in a discontinuous density gradient. J Lab Clin Med 1967;69:659-674.

18 Piomelli $S$ \& Seaman C. Mechanism of red blood cell aging: relationship of cell density and cell age. Am J Hemarol 1993;42:46-52.

19 Seip M. The reticulocyte maturation in the peripheral blood. In: Reticulocyte studies. Seip M, ed. Oslo: Johan Grundt Tanum Forlag, 1953:49-68.

20 Gruden $\mathrm{N}$. The effect of parenteral iron administration upon iron absorption in young rats. Nutr Rep Intern 1988;38:955-960.

21 Kreuzer M \& Kirchgessner M. Endogenous iron excretion. A quantitative means to control iron metabolism? Biol Trace Elem Res 1991;29:77-92.

22. Conrad ME. Physiology of the gastrointestinal tract. 2nd edit. New York: Raven, 1987.

23 Conrad ME, Wientraub LR \& Crosby WH. The role of the intestine in iron kinetics. I Clin Invest 1964;43:963-974.

24 Rennie CM, Thompson S, Parker AC \& Maddy A. Human erythrocyte fraction in "Percoll" density gradients. Clin Chim Acta 1979;98:119-125.

25 Wharf SG, Fox TE, Eagles J \& Fairweather-Tait SJ. A stable isotope method for determining iron bioavailability from infant weaning foods. In: Bioavailability '93. Nutritional, chemical and food processing implications of nutrient availability. Schlemmer U, ed. Karlsruhe: Bundesforschungsanstalt für emähnung. 1993:254-257.

26 Kastenmayer P, Davidsson L, Galan P, Cherouvrier F, Hercberg S \& Hurrell RF. A double stable isotope technique for measuring iron absorption in infants. Br J Nutr 1994;71:411-424.

27 Fairweather-Tait S, Fox T, Wharf SG \& Eagles J. The bioavailability of iron in different weaning foods and the enhancing effect of a fruit drink containing ascorbic acid. Pediatr Res $1995 ; 37: 389-394$. 


\section{4}

\section{A new method to measure iron absorption from the enrichment of ${ }^{57} \mathrm{Fe}$ and ${ }^{58} \mathrm{Fe}$ in young erythroid cells}

Ellen GHM van den Heuvel, Theo Muijs, Hillie Pellegrom, Joost $\mathbb{P}$ Bruyntjes, Wim van Dokkum, Steven Spanhaak and Gertjan Schaafsma

Clinical Chemistry, accepted for publication

\section{Abstract}

Iron absorption can be measured by the incorporation of stable iron isotopes into erythrocytes, $14 \mathrm{~d}$ after isotope administration. The disadvantage of this method is the high dose of isotopes needed to obtain a sufficient enrichment.

Therefore, in this study cell fractions rich in young erythroid cells were prepared using a density separation method. From 10 women blood was taken 4,5 and $7 \mathrm{~d}$ after oral and intravenous administration of ${ }^{57} \mathrm{Fe}$ and ${ }^{58} \mathrm{Fe}$. In these cell fractions and in whole-blood taken $14 d$ after isotope administration, isotope enrichment was measured and absorption calculated.

Absorption calculated from the isotope enrichment in the reticulocyte-rich cell fractions (12.2 \pm SEM 3.7\%) was not significantly different from absorption based on whole-blood values $(13.0 \pm 3.3 \%)$. Because a three-times higher isotope enrichment was found in the cell fractions, the required dose of stable isotopes can be reduced to one-third of the doses use in the traditional method without loss of sensitivity. 


\section{Introduction}

The incorporation of two radioactive iron ( $\mathrm{Fe}$ ) isotopes, given intravenously and orally, into erythrocyte haemoglobin is a well-known method of measuring intestinal Fe absorption and yielded almost the same values as the technique based on wholebody counting $[1,2]$. Because of concern regarding the use of radioisotopes in human subjects, especially in infants and pregnant women, the use of stable isotopes is gaining popularity. Barrett et al [3] measured absorption of non-haem Fe by measuring the incorporation of an intravenously (i.v.) and orally administered stable Fe isotope into erythrocytes of blood sampled two weeks after administration. This method, however, has two disadvantages. First, relatively large amounts of isotopes are needed to sufficiently enrich the circulating red cells [4] and for the oral dose this can vary from around $10 \%$ of daily $\mathrm{Fe}$ intake in children to five times the daily $\mathrm{Fe}$ intake in adults [5]. Second, the high dose of stable isotopes needed makes the method very expensive.

To reduce the required dose of stable isotopes an alternative method was tested. This method is based on the high rate of utilization of administered Fe isotopes within 3.5 d by young erythroid cells. It is known that 80 to $93 \%$ of newly absorbed Fe is incorporated into red blood cells within 2 weeks after administration [6, 7]. About half of that amount is present in young erythroid cells in the circulating blood after 3 to $4 \mathrm{~d}$ of administration [6]. As erythrocytes live about $110 \mathrm{~d}$, and every day only $0.9 \%$ of this cell population is replaced, the isotopes in the newly formed erythrocytes will be diluted strongly when they enter the circulation in the form of reticulocytes. By preparing cell fractions rich in young erythroid cells it should be possible to find a higher isotope enrichment.

The aim of the present study was to investigate whether a higher enrichment value could be obtained by preparing cell fractions rich in young erythroid cells. Moreover, we wished to compare Fe absorption, measured by the incorporation of stable isotopes into young erythroid cells of blood sampled 4,5 or $7 \mathrm{~d}$ after isotope administration, with the simultaneous measurement of $\mathrm{Fe}$ absorption calculated from the enrichment of stable isotopes in whole-blood sampled $14 \mathrm{~d}$ after isotope administration. The decision to prepare reticulocyte-rich cell fractions of blood taken 
4,5 and $7 \mathrm{~d}$ after the last days of isotope administration was based on the enrichment of ${ }^{58} \mathrm{Fe}$ in cell fractions isolated $2,3,4,5,6,7$ and $14 \mathrm{~d}$ after intravenous administration of ${ }^{58} \mathrm{Fe}$ by 4 male subjects in a pilot experiment (unpublished data). On Day 4 the enrichment of ${ }^{58} \mathrm{Fe} /{ }^{56} \mathrm{Fe}$ reached a plateau that lasted until $7 \mathrm{~d}$ after intravenous administration of ${ }^{58} \mathrm{Fe}$. On Day 14 the enrichment in the cell fractions decreased. By preparing the cell fractions on Days 4,5 and 7 in the present study, we could find out whether a plateau enrichment was reached for both the orally and the intravenously administered isotope.

\section{Materials and methods}

Subjects

Ten healthy women aged 20 to 30 were selected for the study (body weight (mean \pm SD) $62.7 \pm 7.4 \mathrm{~kg}$, height $172 \pm 6.4 \mathrm{~cm}$ ). Women were chosen as they show a wide range in Fe status and therefore also in absorption. Normal health was assessed at pre-study screening, which included a medical history and physical examination. None of the subjects was taking dietary supplements or had donated blood in the month before the study. Two were smokers but agreed not to smoke during the study. The study protocol was approved by the TNO external Medical Ethics Committee and all subjects signed informed consent forms.

\section{Stable isotopes}

The stable isotopes were obtained from Chemgas (Boulogne, France) in the form of Fe metal. The abundances of the different Fe isotopes in the metal, as measured by inductively coupled plasma mass spectrometry (ICP-MS), were: Fe enriched in ${ }^{57} \mathrm{Fe}$, $0 \%{ }^{54} \mathrm{Fe}, 3.0 \%{ }^{56} \mathrm{Fe}, 95.15 \%{ }^{57} \mathrm{Fe}$ and $1.85 \%{ }^{58} \mathrm{Fe}$; Fe enriched in ${ }^{58} \mathrm{Fe}, 0.01 \%{ }^{54} \mathrm{Fe}$, $0.03 \%{ }^{56} \mathrm{Fe}, 8.07 \%{ }^{57} \mathrm{Fe}$ and $91.9 \%{ }^{58} \mathrm{Fe}$.

Before administration, these isotopes were prepared as ${ }^{57} \mathrm{Fe}$ or ${ }^{58} \mathrm{Fe}$ ferric sulphate, according to the method of Barrett et al [3]. ${ }^{57} \mathrm{Fe}$ and ${ }^{58} \mathrm{Fe}$ were mixed with $0.5 \mathrm{~mol} / \mathrm{l}$ $\mathrm{H}_{2} \mathrm{SO}_{4}$ and heated to $50{ }^{\circ} \mathrm{C}$ until dissolved. To the ${ }^{57} \mathrm{Fe}$ and ${ }^{58} \mathrm{Fe}$ solutions deaerated, deionized water was added giving a measured Fe concentration of exactly $1.52 \mathrm{mg} / \mathrm{ml}$ Fe and $126 \mu \mathrm{g} / \mathrm{ml} \mathrm{Fe}$, respectivelly. 
The solutions were sterilized by filtration into vials. In the morning of the test days before the subjects arrived, $\mathrm{Fe}^{3+}$ was reduced to $\mathrm{Fe}^{2+}$ by adding $20 \mathrm{mg}$ of vitamin $\mathrm{C}$ tc $5 \mathrm{ml}$ of ${ }^{57} \mathrm{Fe}$ sulphate or $10 \mathrm{mg}$ of vitamin $\mathrm{C}$ to $2 \mathrm{ml}{ }^{58} \mathrm{Fe}$ sulphate.

\section{Study design}

To avoid possible saturation of the mucosal cells with $\mathrm{Fe}$, the subjects consumed a low-Fe diet for $3 \mathrm{~d}$ before isotope administration. The subjects also consumed a lowFe diet during 3 d of isotope administration, to keep total Fe intake constant. The average diet contained $6.1 \mathrm{mg}$ of Fe and $9.5 \mathrm{MJ}$ of energy, of which $13 \%$ came from protein, $31 \%$ from fat and $56 \%$ from carbohydrate, as computed from the Dutch Food Composition Table [8].

In the morning of Days -3 to -1 after an overnight fast, the subjects came to the research institute. The first day a blood sample of $40 \mathrm{ml}$ was taken, of which $30 \mathrm{ml}$ was put in a lithium heparin tube for measurement of basal Fe-isotope ratios. The remainder was divided over sample tubes for measurement of haemoglobin ( $\mathrm{Hb})$ level, serum ferritin concentration and transferrin saturation.

After blood sampling, $150 \mathrm{ml}$ of orange juice containing ca. $7.5 \mathrm{mg}$ enriched ${ }^{57} \mathrm{Fe}^{2+}$ was drunk at the beginning of a standardized light breakfast, which consisted of white bread with sweet dressing and contained $0.8 \mathrm{mg}$ Fe. No coffee or tea was allowed until two hours after lunch.

On Days -2 and -1 , two hours after a similar breakfast, which included the orange juice with ${ }^{57} \mathrm{Fe}^{2+}$, ca. $250 \mu \mathrm{g}$ of enriched ${ }^{58} \mathrm{Fe}^{2+}$ was injected intravenously and simultaneously with $10 \mathrm{ml}$ of saline via a three-way tap. The opening used for the injection of the intravenous solution was flushed clean with saline. Both the oral and the intravenous dose were weighed carefully. The final mean oral and intravenous doses were $23.3 \pm 0.2$ (SD) $\mathrm{mg}$ of ${ }^{57} \mathrm{Fe}$ and $448.5 \pm 6.6 \mu \mathrm{g}$ of ${ }^{58} \mathrm{Fe}$, respectively.

After the isotope administrations on Days -3 to -1 , the subjects left the research institute with the diet for the rest of the day.

Four, 5, 7 and $14 \mathrm{~d}$ after the administration of the stable isotopes, 20 to $30 \mathrm{ml}$ of blood was taken and transferred into a lithium heparin tube. Erythrocytes of the blood sampled on Days $-3,4,5$ and 7 were separated by a Percoll density gradient to isolate 
reticulocyte-enriched cell fractions [9]. Enrichment of reticulocytes was determined by means of thiazole orange labelling of reticulocytes in combination with flow cytometric analysis.

A time schedule is given in Figure 1.

Figure 1 Time schedule (Day -1 is followed by Day 1 ).

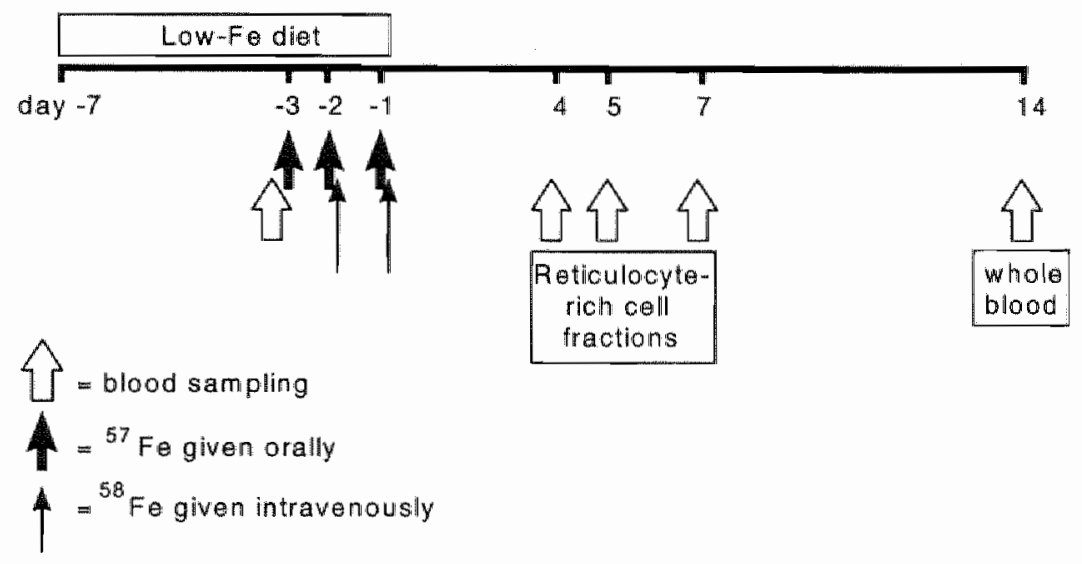

Both the reticulocyte-enriched fractions of Days $-3,4,5$ and 7 and the whole-blood samples of Days -3 and 14 were prepared for inductively coupled plasma mass spectrometric (ICP-MS) analysis of the stable isotope ratios. From the enrichment of the ${ }^{57} \mathrm{Fe} /{ }^{56} \mathrm{Fe}$ and ${ }^{58} \mathrm{Fe} /{ }^{56} \mathrm{Fe}$ ratios over 4,5 or $7 \mathrm{~d}$ in reticulocyte-enriched cell fractions or over the 2-week interval in erythrocytes of whole-blood, Fe absorption was calculated according to the formula described by Barrett et al [3]:

Absorption of $\left.{ }^{57} \mathrm{Fe}(\mathrm{mg})=\left[\left(\frac{\Delta^{57} \mathrm{Fe} e^{56} \mathrm{Fe}}{\Delta^{58} \mathrm{Fe} e^{56} \mathrm{Fe}}\right) \mathrm{x}^{58} \mathrm{Fe}(i \mathrm{v}+\mathrm{po})\right]\right]^{-57} \mathrm{Fe}(i \mathrm{v})$ 
in which $\Delta^{57} \mathrm{Fe} /{ }^{56} \mathrm{Fe}$ is the enrichment of ${ }^{57} \mathrm{Fe} /{ }^{56} \mathrm{Fe}$ ratio, $\Delta^{58} \mathrm{Fe} /{ }^{56} \mathrm{Fe}$ the enrichment of the ${ }^{58} \mathrm{Fe} /{ }^{56} \mathrm{Fe}$ ratio, iv intravenous and po the percentage of absorption of ${ }^{58} \mathrm{Fe}$ given orally.

The percentage of oral absorption is calculated by:

$$
\text { Percentage of } \mathrm{Fe} \text { absorption }=\frac{\text { amount of }{ }^{57} \mathrm{Fe} \text { absorbed }(\mathrm{mg})}{\text { amount of }{ }^{57} \mathrm{Fe} \text { given }(\mathrm{mg})}
$$

\section{Analysis of iron status variables}

After lysing the erythrocytes, haemoglobin was determined by spectrometric measurement of haemoglobincyanide with a Sysmex K-1000 Haematology Analyser (Toa Medical Electronics, Japan). Serum ferritin was measured by an enzyme immunoassay (sandwich) with an AIA-600 (TOSOH Corporation, Japan). Serum Fe was measured with FerroZine (Hach Chemical Co., Ames, IA) without deproteinization (Boehringer Mannheim Diagnostica, Germany). Total Fe-binding capacity (TIBC) was determined by saturating transferrin with an excess of $\mathrm{Fe}^{3+}$ ions, followed by the addition of magnesium carbonate which removes all the $\mathrm{Fe}$ not bound to serum transferrin (Boehringer Mannheim Diagnostica, Germany). Percentage of transferrin saturation was calculated as serum Fe/TIBC $\times 100$.

\section{Density separation}

To separate young and old erythrocytes, red blood cells were fractionated by discontinuous density gradient with Percoll (Pharmacia Biotech Benelux). A BSAHEPES-buffered solution and a BSA-Percoll-HEPES-buffered solution, as described by Salvo et al [9], were mixed to form six solutions with a final Percoll concentration of $57 \%, 58.5 \%, 60 \%, 61.5 \%, 63 \%$ and $64.5 \%$. Discontinuous six-layer gradients were prepared by superimposing $6 \mathrm{ml}$ of each Percoll solution in a $50 \mathrm{ml}$ conical tube (Becton Dickinson Labware, Lincoln Park, NJ) starting with the $64.5 \%$ solution. Optimum conditions were obtained when a quantity of $4 \mathrm{ml}$ whole-blood was layered on top of the gradient. Centrifugation was carried out at $1000 \mathrm{xg}$ for $10 \mathrm{~min}$ at $20^{\circ} \mathrm{C}$ [9]. Cell fractions from the layers with the lowest Percoll concentration were obtained 
with a Pasteur pipette and washed once with HEPES-buffered isotonic saline, followed by centrifugation at $300 \mathrm{xg}$ for $10 \mathrm{~min}$ at $4^{\circ} \mathrm{C}$ to remove Percoll. For each volunteer 4 blood samples of $4 \mathrm{ml}$ were processed by density separation on Day -3 . The cell fractions for each subject were combined to obtain a cell fraction with a sufficient amount of Fe for measurement by ICP-MS. Because the combined cell fraction obtained on Day - 3 for some of the subjects contained a low amount of $\mathrm{Fe}$, cell fractions of six 4-ml blood samples were isolated and combined on Days 4, 5 and 7 .

\section{Determination of erythroid cells}

To $5 \mu \mathrm{l}$ of each combined cell fraction or whole-blood $1 \mathrm{ml}$ of thiazole orange (Becton Dickinson, Reticount) was added. After 30 min of incubation in the dark the percentage of reticulocytes was measured with an Epics Elite flow cytometer (Coulter) on the basis of their fluorescence signals at $525 \mathrm{~nm}$ after excitation with $488 \mathrm{~nm}$ light. Based on the fluorescence and forward scatter characteristics, leucocytes and platelets were discriminated from erythrocytes. The percentage of reticulocytes gave an impression of the efficiency of the separation.

About $2.5 \mathrm{ml}$ of each remaining part of the six cell fractions was resuspended in 0.5 $\mathrm{ml}$ of HEPES-buffered isotonic saline. Of these mixtures the recovery of the total number of erythrocytes was determined with a cell counter (Charles Goffin, CC180). The total amount of erythrocytes gave an impression of the amount of $\mathrm{Fe}$.

ICP-MS

The cell fractions and whole-blood samples were prepared for the ICP-MS analysis of the stable isotope ratios ${ }^{57} \mathrm{Fe} /{ }^{56} \mathrm{Fe}$ and ${ }^{58} \mathrm{Fe} /{ }^{56} \mathrm{Fe}$ [10]. After destruction of the samples in a Teflon tube with concentrated nitric acid, the $\mathrm{pH}$ was adjusted to $3.0 \pm 0.5$ with ammonia. $\mathrm{Fe}$ was isolated by selective extraction with $1 \%$ sodium diethyldithiocarbamate (trihydrate) into $\mathrm{CCl}_{4}$. The water layer was rejected. The carbon tetrachoride layer was then left overnight with $10-20 \mathrm{ml}$ of $1.4 \mathrm{~N} \mathrm{HNO}_{3}$. The $\mathrm{HNO}_{3}$ layer was used for the ICP-MS (Perkin Elmer Sciex, Elan 500) measurement. All measurements were carried out in isotope ratio peak hopping mode. The ICP-MS 
was operated in the high resolution mode to provide maximal accuracy. Typical conditions for operations were: plasma power $1.2 \mathrm{~kW}$, reflected power $<5 \mathrm{~W}$, coolant Ar-flow rate $18 \mathrm{l} / \mathrm{min}$, dwell time $20 \mathrm{msec}, 1$ measurement per peak, 10 repeats per integration, total measuring time $270 \mathrm{sec}$. ICP-MS plasma was optimized to reduce the possible molecular interference at $\mathrm{m} / \mathrm{z} 56$ of $\mathrm{ArO}^{+}[11]$.

The $\mathrm{Fe}$ concentration in the $\mathrm{HNO}_{3}$ solution was measured by atomic absorption spectrometry. A Fe concentration of about $1.0 \mu \mathrm{g} / \mathrm{ml}$ was necessary to produce a signal to obtain a high precision and to avoid saturation of the detection system.

During each ICP-MS run, solutions of an Fe standard $(1.0 \mu \mathrm{g} / \mathrm{ml})$, blank, $\mathrm{HNO}_{3}$ and a sample were analysed for the ${ }^{57} \mathrm{Fe} /{ }^{56} \mathrm{Fe}$ and ${ }^{58} \mathrm{Fe} /{ }^{56} \mathrm{Fe}$ isotope ratios. The results of the samples were corrected for the small interference of $\mathrm{ArO}^{+}$at ${ }^{56} \mathrm{Fe}$. Minor adjustments in bias were made for unknown factors by comparing standards with accepted natural abundances. All samples were measured in duplicate. All cell fractions and wholeblood samples from one subject were analysed within one day to reduce variability. Therefore, the measurement of basal ratios in whole-blood or cell fractions of all subjects had to be spread over several days.

The precision of the ${ }^{57} \mathrm{Fe} /{ }^{56} \mathrm{Fe}$ and ${ }^{58} \mathrm{Fe} /{ }^{56} \mathrm{Fe}$ isotope ratios in cell fractions was tested in a pre-study, in which the basal ratios in 3 cell fractions of 3 subjects were isolated and analysed in duplicate by ICP-MS within one day. The mean basal ${ }^{57} \mathrm{Fe} /{ }^{56} \mathrm{Fe}$ and ${ }^{58} \mathrm{Fe} /{ }^{56} \mathrm{Fe}$ ratios of these isolated cell fractions were $0.0245(\mathrm{CV} 1.1 \%)$ and 0.00305 (CV 2.0\%) and the within-subject $\mathrm{CV}$ was $0.31 \%$ and $0.98 \%$, respectively.

\section{Statistics}

Statistical comparisons between Fe absorption calculated from the enrichment measured in whole-blood on Day 14 and Fe absorption based on the isolated cell fractions were made by using the technique of Bland and Altman [12]. Briefly, comparison of Fe absorption determined by the two methods $\left(x_{a}\right.$ and $\left.x_{b}\right)$ is made by calculating the difference $\left(d_{a b}\right)$. Because the differences are normally distributed, $95 \%$ of them will lie within 2 SD from the mean difference $\left(\vec{d}_{a b}\right)$. Two methods are said to give results that agree when the $95 \%$ confidence limits are sufficiently narrow.

Moreover, the correlation between Fe absorption determined by the two methods and 
the correlation between serum ferritin and Fe absorption were calculated by correlation analyses [13]. Because serum ferritin did not have a symmetric distribution, the logarithm was used in statistical analysis.

Table 1 Percentage of reticulocytes and enrichment of ${ }^{57} \mathrm{Fe} /{ }^{56} \mathrm{Fe}$ and ${ }^{58} \mathrm{Fe} /{ }^{56} \mathrm{Fe}$ in whole-blood and cell fractions from which absorption was calculated ${ }^{1}$

\begin{tabular}{|c|c|c|c|c|}
\hline & \multicolumn{3}{|c|}{ Isolated cell fractions } & \multirow{2}{*}{$\frac{\text { Whole-blood }}{\text { Day } 14}$} \\
\hline & Day $4^{2}$ & Day 5 & Day 7 & \\
\hline $\begin{array}{l}\text { Reticulocytes in whole-blood } \\
\%\end{array}$ & $\begin{array}{c}1.0 \pm 0.1 \\
(0.5-1.7)\end{array}$ & $\begin{array}{l}1.1 \pm 0.1 \\
(0.5-1.9)\end{array}$ & $\begin{array}{c}1.0 \pm 0.1 \\
(0.5-1.8)\end{array}$ & - \\
\hline $\begin{array}{l}\text { Reticulocytes in cell fractions } \\
\%\end{array}$ & $\begin{array}{c}6.6 \pm 1.1 \\
(2.8-10.9)\end{array}$ & $\begin{array}{c}6.3 \pm 1.2 \\
(1.7-13.1)\end{array}$ & $\begin{array}{l}5.6 \pm 1.0 \\
(1.8-12.0)\end{array}$ & - \\
\hline $\begin{array}{l}\text { Enrichment of }{ }^{57} \mathrm{Fe} /{ }^{56} \mathrm{Fe} \\
\end{array}$ & $\begin{array}{l}16.5 \pm 5.4 \\
(1.8-47.9)\end{array}$ & $\begin{array}{l}15.6 \pm 4.7 \\
(1.2-43.9)\end{array}$ & $\begin{array}{l}16.7 \pm 4.9 \\
(1.9-47.8)\end{array}$ & $\begin{array}{c}5.7 \pm 1.3^{3} \\
(1.3-14.1)\end{array}$ \\
\hline $\begin{array}{l}\text { Enrichment of }{ }^{58} \mathrm{Fe} /{ }^{56} \mathrm{Fe} \\
\%\end{array}$ & $\begin{array}{c}22.8 \pm 2.6 \\
(12.3-36.0)\end{array}$ & $\begin{array}{l}20.5 \pm 3.0 \\
(7.8-36.0)\end{array}$ & $\begin{array}{l}18.6 \pm 1.6 \\
(10.7-25.9)\end{array}$ & $\begin{array}{r}7.1 \pm 0.6^{4} \\
(3.9-9.6)\end{array}$ \\
\hline $\begin{array}{l}\text { Absorption } \\
\text { mg }\end{array}$ & $\begin{array}{r}2.7 \pm 0.8 \\
(0.2-7.5)\end{array}$ & $\begin{array}{r}2.9 \pm 0.8 \\
(0.1-7.7)\end{array}$ & $\begin{array}{l}3.1 \pm 0.8 \\
(0.2-8.5)\end{array}$ & $\begin{array}{l}3.0 \pm 0.8 \\
(1.1-8.4)\end{array}$ \\
\hline
\end{tabular}

\section{Results}

All subjects completed the study. Due to illness (cystitis and fever) from Day -6 to Day 6, subject 06 did not adhere to the distributed diet and no blood was sampled on Day 4. We have no evidence that fever and cystitis affect iron incorporation into erythroid cells. The administration of ${ }^{58} \mathrm{Fe}$ to subject 03 was only partly intravenous. Table 1 shows the mean percentage of reticulocytes, the enrichment values of the ${ }^{57} \mathrm{Fe} /{ }^{156} \mathrm{Fe}$ and ${ }^{58} \mathrm{Fe} /{ }^{56} \mathrm{Fe}$ ratios in whole-blood and the cell fractions and the corres- 
ponding absorption values.

Table 2 Individual absorption percentages, calculated with the enrichment of ${ }^{57} \mathrm{Fe} /{ }^{56} \mathrm{Fe}$ and ${ }^{48} \mathrm{Fe}^{35} \mathrm{Fe}$ in whole-blood and in the isolated cell fractions obtained several days after isotope administration

\begin{tabular}{|c|c|c|c|c|}
\hline \multirow[t]{2}{*}{ Subject } & \multicolumn{3}{|c|}{ New method } & \multirow{2}{*}{$\begin{array}{r}\text { Traditional method } \\
\text { Day } 14\end{array}$} \\
\hline & Day 4 & Day 5 & Day 7 & \\
\hline 01 & 0.9 & 0.4 & 1.0 & 4.9 \\
\hline 02 & 31.9 & 32.8 & 36.3 & 35.6 \\
\hline 03 & 7.5 & 6.9 & 8.6 & 5.1 \\
\hline 04 & 6.0 & 5.3 & 6.0 & 7.8 \\
\hline 05 & 15.6 & 16.2 & 21.6 & 15.1 \\
\hline 06 & - & 14.3 & 20.0 & 20.9 \\
\hline 07 & 5.1 & 3.8 & 5.9 & 5.8 \\
\hline 08 & 1.3 & 4.9 & 3.7 & 5.1 \\
\hline 09 & 10.4 & 12.7 & 9.1 & 6.8 \\
\hline 10 & 25.6 & 28.0 & 22.0 & 23.3 \\
\hline$\pm \mathrm{SEM}$ & $6 \pm 3.6$ & $12.5 \pm 3.4$ & $13.4 \pm 3.5$ & $13.0+3.3$ \\
\hline
\end{tabular}

The reticulocyte percentage of the cell fraction prepared on Day -3 was $3.8 \pm 1.8$ and differed significantly from the percentages of reticulocytes present in the isolated cell fractions prepared on Days 4,5 or 7 . The mean amount of Fe per erythrocyte was 8.8 fg.

The enrichment of ${ }^{58} \mathrm{Fe} /{ }^{56} \mathrm{Fe}$ correllated significantly with the reticulocyte $\%$ in the cell fractions isolated on Days 4,5 and $7(n=29, r=0.74, P<0.001)$. Also the amount of ${ }^{57} \mathrm{Fe}$ incorporated into the erythroid cells correlated significantly with the reticulocyte $\%(\mathrm{n}=29, \mathrm{r}=0.41, \mathrm{P}<0.05)$.

Table 2 shows the individual absorption percentages determined by the two different methods. In Figures 2, 3 and 4 , the $Y$-axis shows the difference between $\mathrm{Fe}$ absorption calculated from the enrichment of Fe isotopes in whole-blood and $\mathrm{Fe}$ absorption calculated from the isotope enrichment in the isolated cell fractions of 
Days 4,5 or 7 , respectively. The average of the two methods is shown on the X-axis. The $\pm 2 S D$ confidence interval for the differences is also shown. The results indicate that the Fe absorption calculated from the enrichment in the isolated cell fractions of Days 4,5 or 7 could be expected to differ by as much as ca. $-4.6 \%,-3.9 \%$ and $2.9 \%$, respectively, from the 'old' method. No significant differences were found between the 'new' and 'old' method. As expected, Fe absorption calculated from the isotope enrichment in cell fractions isolated on Days 4, 5 or 7 correlated significantly with Fe absorption calculated from the isotope enrichment in whole-blood $(r=0.96, r=0.93$ and $\mathrm{r}=0.96$, respectively).

Figure 2 Comparison of two methods for determining Fe absorption. The differences between percentage Fe absorption determined by the 'new' method (Day 4) and the old method vs. the average value of these two $\mathrm{Fe}$ absorption percentages at each determination are plotted using the procedure of Bland and Altman [12]. The solid central horizontal line shows the mean of the differences, and the dashed upper and lower lines show $\pm 2 \mathrm{SD}$ from this mean.

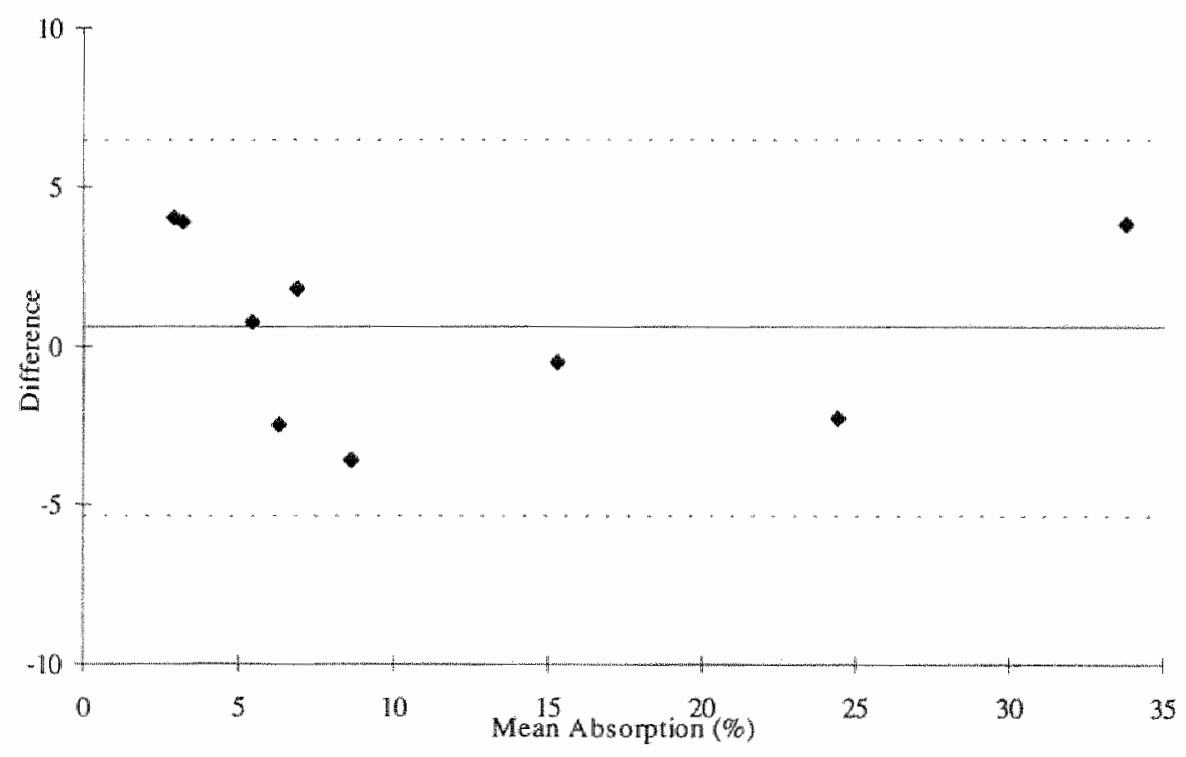


mong subjects a broad range in Fe status was found. The mean $( \pm \mathrm{SD}) \mathrm{Hb}$, serum ferritin, TIBC and transferrin saturation were $130.2 \pm 7.1 \mathrm{~g} / 1,27.0 \pm 26.6 \mu \mathrm{g} / \mathrm{l}, 75.6 \pm$ $16.6 \mu \mathrm{mol} / \mathrm{I}$ and $22.4 \pm 8.6 \%$, respectively. Fe absorption calculated from the enrichment of ${ }^{57} \mathrm{Fe} /{ }^{56} \mathrm{Fe}$ and ${ }^{58} \mathrm{Fe} /{ }^{56} \mathrm{Fe}$ in the cell fractions of Days 4,5 and 7 and whole-blood correlated significantly with serum ferritin (see Figure 5). No significant differences were found between these correlation coefficients.

Figure 3 Comparison of two methods for determining Fe absorption. The differences between percentage Fe absorption determined by the 'new' method (Day 5) and the old method vs. the average value of these two $\mathrm{Fe}$ absorption percentages at each determination are plotted using the procedure of Bland and Altman [12]. The solid central horizontal line shows the mean of the differences, and the dashed upper and lower lines show \pm 2 SD from this mean.

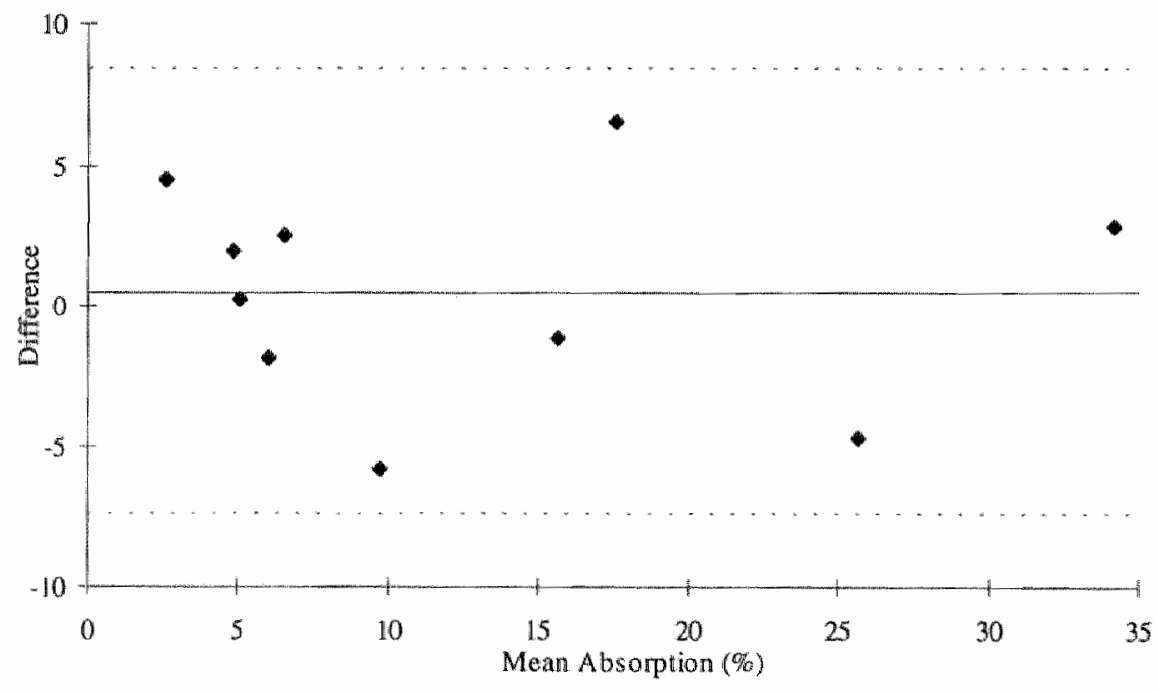

\section{Discussion}

In the present study, reticulocyte-rich cell fractions were obtained a few days after isotope administration, to find out whether a higher enrichment of the isotopes in 
these fractions can be achieved than in whole-blood, so that the dose of isotopes can be reduced. To determine the efficiency of the density separation method the reticulocyte percentage was measured in the prepared cell fractions. A 4 to 6 times higher percentage of reticulocytes was found in the cell fractions than in wholeblood. The lower reticulocyte percentage in the cell fractions obtained on Day -3 as compared with the cell fractions obtained on Days 4,5 and 7 could be attributed to the difference in total amount of blood separated on Day -3 versus Days 4, 5 or 7 . Moreover, the density of the batch of Percoll $(1.130 \mathrm{~g} / \mathrm{ml})$ used for density separation on Days 4,5 and 7 was $0.003 \mathrm{~g} / \mathrm{ml}$ higher than the Percoll density used on Day -3 .

Figure 4 Comparison of two methods for determining Fe absorption. The differences between percentage Fe absorption determined by the 'new' method (Day 7) and the old method vs. the average value of these two $\mathrm{Fe}$ absorption percentages at each determination are plotted using the procedure of Bland and Altman [12]. The solid central horizontal line shows the mean of the differences, and the dashed upper and lower lines show $\pm 2 S D$ from this mean.

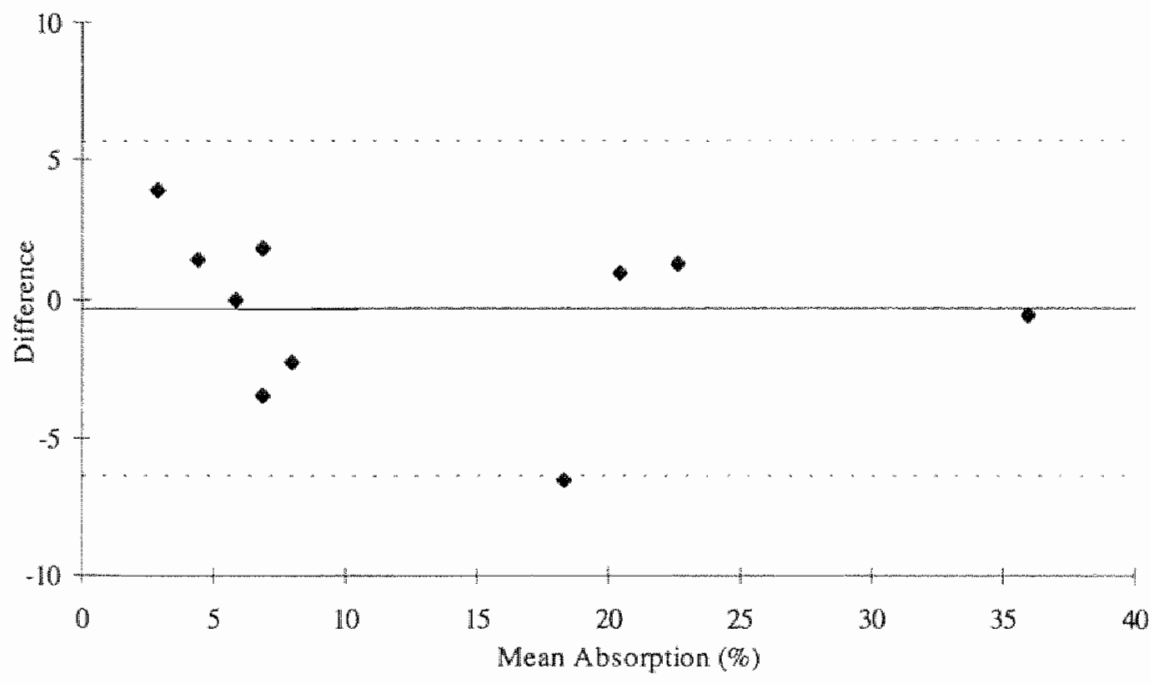

In the study of Barrett et al [3] the average enrichment of the ${ }^{58} \mathrm{Fe} /{ }^{56} \mathrm{Fe}$ and ${ }^{57} \mathrm{Fe} /{ }^{56} \mathrm{Fe}$ 
ratios in whole-blood of 5 women after intravenous and oral administration of ca. 520 $\mu \mathrm{g}$ of ${ }^{58} \mathrm{Fe}$ and $8.5 \mathrm{mg}$ of ${ }^{57} \mathrm{Fe}$ was $11.9 \%$ (range $9.6-13.8 \%$ ) and $4.8 \%$ (range 1.9 $7.4 \%$ ), respectively. In the present study the enrichment of the ${ }^{58} \mathrm{Fe} /{ }^{56} \mathrm{Fe}$ ratio in whole-blood was lower due to a lower dose of ${ }^{58} \mathrm{Fe}$ and because subject 03 got the injection only partially intravenously. Without subject 03 , the average enrichment of the ${ }^{58} \mathrm{Fe} /{ }^{56} \mathrm{Fe}$ ratio was $7.5 \%(6.0-9.6 \%)$, resulting in an average $\mathrm{Fe}$ incorporation of $82.8 \%(69-99 \%)$, which is comparable to the average incorporation of ${ }^{58} \mathrm{Fe}$ of $80.8 \%$ (range 68-93\%) found by Barrett et al [3]. Although the incorporation of ${ }^{58} \mathrm{Fe}$ in subject 03 was only $40.2 \%$, the enrichment of the ${ }^{58} \mathrm{Fe} /{ }^{56} \mathrm{Fe}$ ratio in subject 03 was included in the calculation of absorption, because no estimation of incorporation of absorbed $\mathrm{Fe}$ in the cell fractions is available as it is for the incorporation in wholeblood after $14 \mathrm{~d}$ of isotope administration. Therefore, the absorption value is probably not the correct percentage. However, because this is the case for both methods it does not influence the validation of the new method.

In the cell fractions a 3 times higher isotope enrichment was found than in wholeblood. The enrichment of the ${ }^{58} \mathrm{Fe} /{ }^{56} \mathrm{Fe}$ and ${ }^{57} \mathrm{Fe} /{ }^{56} \mathrm{Fe}$ ratios in the cell fractions did not differ between Days 4, 5 or 7 . This indicates that each of these days is equally suitable for blood sampling. As could be expected, the incorporation of ${ }^{58} \mathrm{Fe}$ and ${ }^{57} \mathrm{Fe}$ into erythroid cells was related to the percentage of reticulocytes in the cell fractions. Since the enrichment of both ${ }^{57} \mathrm{Fe} /{ }^{56} \mathrm{Fe}$ and ${ }^{58} \mathrm{Fe} /{ }^{56} \mathrm{Fe}$ was measured in the same cell fraction, the calculated absorption percentages are independent of the number of young erythroid cells in these cell fractions. Therefore, no significant difference was found between absorption percentages calculated from the isotope enrichment in the cell fraction of Days 4,5 and 7 . The standard deviation of these absorption percentages was $1.95 \%$ absorption and is in accordance with the precision of the ICPMS analyses. 
Figure 5 Correlation between serum ferritin after log transformation and absorption $\% \%_{4}$ calculated from the isotope enrichment measured in the cell fractions on Days 4,5 and 7 and wholeblood of Day 14.

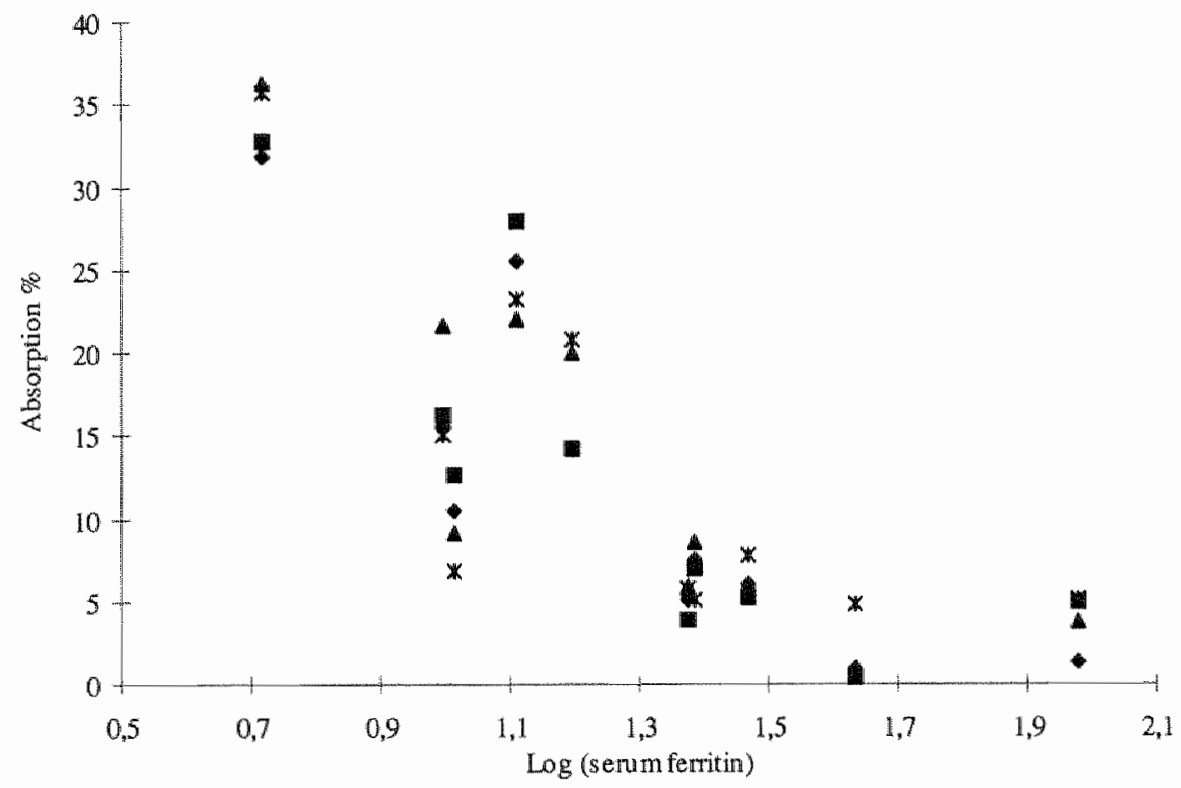

-Day 4: absorption $\%=-23.7 \mathrm{log}$ (serum ferritin) + 42.4; residual standard deviation $=6.3 ; \mathrm{r}=0.84 ;$ Day 5: absorption $\%=-23.5 \log$ (serum ferritin) $+42.8 ;$ residual standard deviation $=6.9 ; \mathrm{r}=0.80 ; \Delta D a y$; absorption $\%=-25.4 \mathrm{log}$ (serum ferritin) +46.1 ; residual standard deviation $=6.6 ; \mathrm{r}=0.83 ; *$ Day 14: absorption $\%=-21.2 \log$ (serum ferritin) +40.4 ; residual standard deviation $=7.6 ; \mathrm{r}=0.73$; Remank: Although the illness of subject 6 may have influenced her serum ferritin wallue, the regression equation only slighuly changed when subject 6 was left out.

Fe absorption calculated from the enrichment of both ${ }^{57} \mathrm{Fe} /{ }^{56} \mathrm{Fe}$ and ${ }^{58} \mathrm{Fe} /{ }^{56} \mathrm{Fe}$ measured in cell fractions of Days 4, 5 or 7 did not differ significantly from Fe absorption calculated from the enrichment of the isotope ratios in whole-blood. Moreover, a clear correlation was found between serum ferritin and $\mathrm{Fe}$ absorption based on isotope enrichment in cell fractions or whole-blood, indicating that both methods measure Fe absorption to be expected on a physiological basis, as Fe absorption is 
inversely related to Fe status [14]. The differences between Fe absorption percentage based on the cell fractions of Days 4,5 or 7 and absorption based on whole-blood were between $-0.38 \%$ and $+0.58 \%$. Although a maximum enrichment should be present, to estimate absorption it does not seem to matter on which day $(4,5$ or 7$)$ the cell fractions are obtained.

In conclusion, a three times higher enrichment of both ratios was found in the reticulocyte-enriched cell fractions than in whole-blood. This, together with the significant correlation between enrichment of ${ }^{58} \mathrm{Fe} /{ }^{56} \mathrm{Fe}$ and the reticulocyte percentage in isolated cell fractions, demonstrates that it is possible to achieve a higher enrichment with the same dose of stable isotopes by preparing cell fractions with young erythroid cells. Absorption based on the isotope enrichment values in the cell fractions rich in young erythroid cells was essentially the same as absorption calculated from the isotope enrichment in whole-blood. As the enrichment is three times higher, the required dose of stable isotopes can be reduced pro rata. When labour is included this results in a total cost savings of $35 \%$ for women and $55 \%$ for men.

\section{References}

1 Lunn JA, Richmond J, Simpson JD, Leask JD \& Tothill P. Comparison between three radioisotope methods for measuring iron absorption. Br Med J 1967;3:331-333.

2 Werner E, Roth P, Hansen C \& Kaltwasser JP. Comparative evaluation of intestinal iron absorption by four different methods in man. In: Structure and function of iron storage and transport proteins. Urushizaki I, et al, eds. Elsevier Science Publishers BV, 1983:403-408.

3 Barrett JF, Whittaker PG, Willians IG \& Lind T. Absorption of non-haem iron in norma! women measured by the incorporation of two stable isotopes into erythrocytes. Clin Sci $1992 ; 83: 213-219$.

4 Hurrell RF. Bioavailability of iron. Eur J Clin Nutr 1997;51:S4-S8.

5 Sandström B, Fairweather-Tait S, Hurrell R \& Van Dokkum W. Methods for studying mineral and trace element absorption in humans using stable isotopes. Nutr Res Rev 1993;6:71-95.

6 Bothwell TH, Chartton RW, Cook JD \& Finch CA. Internal iron kinetics. In: Iron metabolism in man. Bothwell TH, Charlton RW, Cook JD, Finch CA, eds. London: Blackwell Scientific Publications, 1979:327-335.

7 Larsen L \& Milman N. Normal iron absorption determined by means of whole body counting and red cell incorporation of ${ }^{59} \mathrm{Fe}$. Acta Med Scand 1975;198:271-274.

8 Nevo Foundation Editorial Board. Food composition table 1996. Zeist. The Netherlands: Nevo foundation, 1996:235 p. 
9 Salvo G, Caprari P, Samoggia P, Mariani G \& Salvati AM. Human erythrocyte separation according to age on a discontinuous "Percoll" density gradient. Clin Chim Acta $1982 ; 122: 293-300$.

10 Luten JB, Muijs T \& Van Dokkum W. The determination of stable isotope ratio of zinc, copper, iron in faeces and calcium in urine by ICP-MS. In: Bioavailability '93. Nutritional, chemical and food processing implications of nutrient availability. Schlemmer $\mathrm{U}$, ed. Karlsruhe: Bundesforschungsanstalt für Emährung, 1993:161-168.

11 Gray AL \& Williams JG. System optimisation of the effect on polyatomic, oxide and double charged ion response of a commercial inductively coupled plasma mass spectrometry instrument. $J$ Anal At Spectrom 1987;2:599-606.

12 Bland JM \& Altman DG. Statistical methods for assessing agreement between two methods of clinical measurement. Lancet 1986;i:307-310.

13 BMDP statistical software manual. Berkeley: University Press of California, 1988.

14 Magnusson B, Björn-Rasmussen E, Hallberg L \& Rossander L. Tron absorption in relation to iron status. Model proposed to express results to food iron absorption measurements. Scand J Haematol 1981;27:201-208. 


\section{Iron absorption study with stable isotopes in women with low iron stores: effect of bovine lactoferrin}

Ellen GHM van den Heuvel, Wim HM Saris, Theo Muijs and Gertjan Schaafsma Submitted for publication

\section{Abstract}

Long-term feeding animal experiments as well as in vitro cell receptor studies have indicated that under conditions of increased iron needs, lactoferrin promotes iron absorption. Therefore, in women with low iron stores the effect of bovine lactoferrin, which may bind specifically to human target cells, on iron absorption was measured using the dual stable isotope technique.

Eight women, aged 19 to 39 years, with low serum ferritin (mean $\pm \mathrm{SD}, 8.1 \pm 2.6$ $\mu \mathrm{g} / 1)$ received 4 treatments according to a randomized design. The treatments consisted of $0 \mathrm{~g}, 0.5 \mathrm{~g}, 2.0 \mathrm{~g}$ or $5.5 \mathrm{~g}$ of bovine lactoferrin added to a maltodextrin drink together with $7.5 \mathrm{mg}$ of ${ }^{57} \mathrm{Fe}$ (in the $\mathrm{Fe}^{2+}$ form) on 2 consecutive days. The molar ratios iron to lactoferrin were equal to $21.8,5.8$ and 2.3 , respectively. ${ }^{58} \mathrm{Fe}$ was injected intravenously on the second day.

The overall mean iron absorption $( \pm \mathrm{SEM})$ was $18.0 \pm 2.0 \%$. No differences were found between treatments $(P=0.9)$, but the intra-subject variation was high. A significant inverse correlation between iron absorption and serum ferritin was only found for the control treatment.

Neither an inhibitory nor a promoting effect of bovine lactoferrin on iron absorption in women with low serum ferritin levels was found. The results are discussed in relation to the high inter- and intra-subject variation, species specificity of the 
lactoferrin receptor and effect of digestive enzymes on lactoferrin.

\section{Introduction}

Lactoferrin (Lf) is an iron-binding protein present in colostrum $(5-7 \mathrm{mg} / \mathrm{ml})$, mature human $(2-3 \mathrm{mg} / \mathrm{ml})$ and bovine milk $(20-200 \mu \mathrm{g} / \mathrm{ml})[1]$. Human ${ }^{59} \mathrm{FeLf}$ and Lf fragments specifically bind to a brush-border membrane receptor [2]. Although no binding of bovine Lf to the specific binding sites for human Lf was shown by Kawakami \& Lönnerdal [3], Spik et al [4] found a comparable inhibition of the binding of ${ }^{125} \mathrm{I}$-radio labelled human $\mathrm{Lf}$ to human $\mathrm{Lf}$ receptor by human and bovine Lf. The number of Lf receptors increased in response to a decrease in intracellular iron (Fe) content of human enterocytes [5]. Therefore, the Lf receptor might be developed in the gut as a means of safeguarding Fe absorption during a period of low Fe supply and high tissue demands, which is confirmed by animal experiments.

In weanling mice the availability of $\mathrm{Fe}$ from $\mathrm{FeCl}_{2}$ and bovine $\mathrm{FeLf}$ was similar under conditions of Fe deficiency. However, if tissue Fe was adequate, the amount of Fe absorbed and/or retained from FeLf was lower [6]. Also in piglets and calves, Fe bound to bovine $\mathrm{Lf}$ was more efficiently utilized than Fe from an inorganic compound, in situations with a higher demand for Fe [7, 8]. Growing, Fe-deficient anaemic rats fed Fe-saturated bovine Lf for $70 \mathrm{~d}$ demonstrated an increase in $\mathrm{Fe}$ status values, which was in contrast to the ferrous sulphate group [9]. As indicated by these animal experiments, it is likely that under conditions of increased Fe needs bovine Lf increases $\mathrm{Fe}$ absorption.

Therefore, the aim of this study was to find out whether bovine Lf also promotes Fe absorption in human subjects with a low Fe status. Fe absorption was measured by a dual stable isotope technique including the analysis of the orally $\left({ }^{57} \mathrm{Fe}\right)$ and intravenously $\left({ }^{5 \%} \mathrm{Fe}\right.$ ) administered isotopes incorporated into erythrocytes.

\section{Methods}

\section{Subjects}

Eight healthy female subjects with an age (mean \pm SD) of $24 \pm 6.8 \mathrm{y}$, a body weight of $65 \pm 8 \mathrm{~kg}$ and a height of $1.74 \pm 0.05 \mathrm{~m}$ were selected for the study. Only Fe- 
deficient subjects $(\mathrm{Hb}<7.4 \mathrm{mmol} / \mathrm{L}$ and serum ferritin $<12 \mu \mathrm{g} / \mathrm{L})$ reporting a typical Dutch food pattern [10] and a regular menstruation were selected. None of the subjects were taking dietary supplements, were smokers or blood donors. The study was approved by the Medical Ethics Committee of the University of Limburg (the Netherlands) and subjects signed informed consent forms according to the EU guidelines for Good Clinical Practice.

\section{Study design}

All subjects received four treatments at two-week intervals according to a randomized cross-over design. The treatments consisted of three different dose levels of Lf $(0.5,2$ and $5.5 \mathrm{~g})$ and a control treatment without Lf. Lf doses were chosen in such a way that Lf was differently saturated with $7.5 \mathrm{mg}$ of Fe, given as a stable isotope. Taking $20 \%$ saturation of $\mathrm{Lf}$ into account, the molar ratios of Fe to $\mathrm{Lf}$ were $21.8,5.8$ and 2.3, respectively. The different amounts of Lf were dissolved in $200 \mathrm{ml}$ of a maltodextrin drink.

\section{Isotope method}

True fractional absorption of $\mathrm{Fe}$ was quantitatively measured as the incorporation of physiological doses of stable $\mathrm{Fe}$ isotopes into red blood cells $13 \mathrm{~d}$ after isotope administration. One isotope $\left({ }^{58} \mathrm{Fe}\right)$ was injected intravenously and another isotope $\left({ }^{57} \mathrm{Fe}\right)$ was administered orally. From the intravenously administered isotope it could be calculated how much of the absorbed Fe was incorporated into erythrocytes. The stable isotopes were obtained from Chemgas (Boulogne, France) in the form of $\mathrm{Fe}$ metal. The abundances of the different $\mathrm{Fe}$ isotopes in the metal, as measured using ICP-MS were: Fe enriched in ${ }^{57} \mathrm{Fe}, 0 \%{ }^{54} \mathrm{Fe}, 3.0 \%{ }^{56} \mathrm{Fe}, 95.15 \%{ }^{57} \mathrm{Fe}$ and $1.85 \%{ }^{58} \mathrm{Fe}$; Fe enriched in ${ }^{58} \mathrm{Fe}, 0.01 \%{ }^{54} \mathrm{Fe}, 0.03 \%{ }^{56} \mathrm{Fe}, 8.07 \%{ }^{57} \mathrm{Fe}$ and $91.9 \%{ }^{98} \mathrm{Fe}$.

Before administration, these isotopes were prepared as ${ }^{57} \mathrm{Fe}$ or ${ }^{58} \mathrm{Fe}$ ferric sulphate, according to the method of Barrett et al [11]. The ${ }^{57} \mathrm{Fe}$ and ${ }^{58} \mathrm{Fe}$ solutions contained exactly $1.5 \mathrm{mg} / \mathrm{ml} \mathrm{Fe}$ and $125 \mu \mathrm{g} / \mathrm{ml} \mathrm{Fe}$, respectively. In the morning of the test days, before the subjects arrived, ${ }^{57} \mathrm{Fe}^{3+}$ was reduced to ${ }^{57} \mathrm{Fe}^{2+}$ by adding $20 \mathrm{mg}$ of vitamin $\mathrm{C}$ to $5 \mathrm{ml}$ of ${ }^{57} \mathrm{Fe}$ sulphate. This solution was added to the maltodextrin drink containing 
different amounts of Lf.

\section{Protocol}

After an overnight fast, the subjects came to the research institute on two consecutive test days. The first day a blood sample of $25 \mathrm{ml}$ was taken, of which $10 \mathrm{ml}$ was put in a lithium-heparin tube for measurement of basal Fe-isotope ratios. The remainder was divided into sample tubes for measurement of the subject's haemoglobin ( $\mathrm{Hb}$ ) level, serum ferritin concentration and transferrin saturation (i.e. serum Fe/total Fe-binding capacity $x$ 100).

After blood sampling, the test drink of maltodextrin with $\mathrm{Lf}$ and ${ }^{57} \mathrm{Fe}$ was consumed at the beginning of a standardized light breakfast, which consisted of white bread, low-fat margarine, jam and a banana. No coffee or tea was allowed until four hours after breakfast. The second day, two hours after a similar breakfast, which included the test drink, ${ }^{58} \mathrm{Fe}$ was injected intravenously. One hour before injection $10 \mathrm{mg}$ of vitamin $\mathrm{C}$ was added to $2.5 \mathrm{ml}$ of the ${ }^{58} \mathrm{Fe}$ solution to obtain ferrous sulphate. After the intravenous administration of this solution the canula was flushed clean with $5 \mathrm{ml}$ saline. The total amount of isotopes (mean \pm SD) administered during the study were $16.29 \pm 0.12 \mathrm{mg}$ enriched ${ }^{57} \mathrm{Fe}$ and $316 \pm 12 \mu \mathrm{g}$ enriched ${ }^{58} \mathrm{Fe}$.

To avoid excess of daily $\mathrm{Fe}$ intake due to the administration of ${ }^{57} \mathrm{Fe}$, the subjects consumed a low-Fe diet during the two days of dose administration. This diet provided $7.6 \mathrm{mg}$ Fe as computed from the Dutch Food Composition Table [12].

The subjects were asked whether the test days were in their menstrual period, because during the menstrual cycle the concentration of Fe status indicators changes [13]. During the total study subjects were requested to adhere to their habitual diet and not to engage in extravagant behavior during the week preceding any of the absorption tests.

Thirteen, 27 and 41 d later, the second, third and fourth absorption tests, respectively, were performed following the same procedure. First a blood sample was taken and then the maltodextrin drink with ${ }^{57} \mathrm{Fe}$ and a certain amount of $\mathrm{Lf}$ was drunk. The blood sample contained the enriched Fe isotope ratios in erythrocytes due to the isotope administration during the earlier Fe absorption test, but was also used to 
establish the basal ratio for the next Fe absorption test.

From the enrichment of the ${ }^{57} \mathrm{Fe} /{ }^{56} \mathrm{Fe}$ and ${ }^{58} \mathrm{Fe} /{ }^{56} \mathrm{Fe}$ ratios absorption was calculated according to the formula described by Barrett et al [11], that includes a correction for the small amount of ${ }^{57} \mathrm{Fe}$ present in the intravenous preparation and conversely the small amount of ${ }^{58} \mathrm{Fe}$ in the oral preparation.

\section{Analytical methods}

Haemoglobin was determined with a Sysmex K-1000 Haematology Analyzer (Toa Medical Electronics, Japan). Serum ferritin was measured by an enzyme immunoassay (sandwich) using an AIA-600 (TOSOH Corporation, Japan). Serum Fe was measured with FerroZine (Hach Chemical Co., Ames, Iowa/USA) without deproteinization (Boehringer Mannheim GmbH Diagnostica, Germany). Total $\mathrm{Fe}$ binding capacity (TIBC) was determined by saturating transferrin with an excess of $\mathrm{Fe}^{3+}$ ions, followed by the addition of magnesium carbonate which removes all the $\mathrm{Fe}$ not bound to serum transferrin (Boehringer Mannheim $\mathrm{GmbH}$ Diagnostica, Germany).

The blood samples were prepared for the inductively coupled plasma mass spectrometry (ICP-MS) analyses of the stable isotope ratios ${ }^{57} \mathrm{Fe} /{ }^{56} \mathrm{Fe}$ and ${ }^{58} \mathrm{Fe} /{ }^{56} \mathrm{Fe}[14]$. After destruction of the samples in a Teflon tube with concentrated nitric acid, the $\mathrm{pH}$ was adjusted to $3.0 \pm 0.5$ with ammonia. Fe was isolated by selective extraction with $1 \%$ sodium diethyldithiocarbamate (trihydrate) into $\mathrm{CCl}_{4}$. The water layer was rejected. The carbon tetrachoride layer was then left overnight with $10-20 \mathrm{ml} 1.4 \mathrm{~N}$ $\mathrm{HNO}_{3}$. The $\mathrm{HNO}_{3}$ layer was used for the ICP-MS (Perkin Elmer Sciex, Elan 500) measurement. All measurements were carried out in isotope ratio peak hopping mode. The ICP-MS was operated in the high resolution mode to provide maximal accuracy. Typical conditions for operations were: plasma power $1.2 \mathrm{~kW}$, reflected power $<5 \mathrm{~W}$, coolant Ar-flow rate $18 \mathrm{l} / \mathrm{min}$, dwell time $20 \mathrm{msec}, 1$ measurement per peak, 10 repeats per integration, total measuring time $270 \mathrm{sec}$.

The $\mathrm{Fe}$ concentration in the $\mathrm{HNO}_{3}$ solution was measured by atomic absorption spectrometry. If necessary, the solution was diluted to adjust the Fe concentration to about $1.0 \mu \mathrm{g} / \mathrm{ml}$ in order to avoid saturation of the detection system. ICP-MS plasma 
was optimized to reduce the possible molecular interference at $\mathrm{m} / \mathrm{z} 56$ of $\mathrm{ArO}^{+}$[15]. During each ICP-MS run, solutions of an Fe standard $(1.0 \mu \mathrm{g} / \mathrm{ml})$, blank, $\mathrm{HNO}_{3}$ and a sample were analyzed for the isotope ratios ${ }^{57} \mathrm{Fe} /{ }^{56} \mathrm{Fe}$ and ${ }^{58} \mathrm{Fe} /{ }^{56} \mathrm{Fe}$. The results of the samples were corrected for the small interference of $\mathrm{ArO}^{+}$at ${ }^{56} \mathrm{Fe}$. The mean ratios ${ }^{57} \mathrm{Fe} /{ }^{56} \mathrm{Fe}$ and ${ }^{58} \mathrm{Fe} /{ }^{56} \mathrm{Fe}$ of the standard solutions were $0.02299(\mathrm{CV} 1.0 \%)$ and 0.00306 ( CV 1.6\%). Minor adjustments in bias were made for unknown factors by comparing standards with accepted natural abundances. All samples were measured in duplicate.

\section{Statistical analysis}

The differences between treatment means were tested by ANOVA with block structure [16] with subject and period of measurement within a block. The differences between treatment means were also analyzed by analysis of covariance, with serum ferritin, TIBC or menstruation in order during the days of the absorption tests as covariates. The mean values of serum ferritin and Fe absorption over the 4 treatments for each subject were calculated. Both these overall means and the individual data were used in correlation analyses [16].

\section{Results}

At the start of the study subjects were selected with haemoglobin values (mean $\pm \mathrm{SD}$ ) of $7.4 \pm 0.2 \mathrm{mmol} / \mathrm{L}$ and serum ferritin concentrations of $8.1 \pm 2.6 \mu \mathrm{g} / \mathrm{l}$. Table 1 shows that all subjects remained Fe-depleted during the study (serum ferritin $<20$ $\mu \mathrm{g} / \mathrm{L}$ ), but not Fe-deficient (serum ferritin $<12 \mu \mathrm{g} / \mathrm{L}, \mathrm{Hb}<7.4 \mathrm{mmol} / \mathrm{L}$, Tf saturation $<15 \%$, TIBC $>71.6 \mu \mathrm{mol} / \mathrm{L}$ [17]. All subjects completed the study. During one treatment, the intravenous injection of ${ }^{58} \mathrm{Fe}$ to one subject did not take place and the average enrichment of ${ }^{58} \mathrm{Fe} /{ }^{56} \mathrm{Fe}$ found during the other treatments was used for calculating absorption.

All blood samples were measured in duplicate. The coefficient of variation within duplicate measurements of the ${ }^{57} \mathrm{Fe} /{ }^{56} \mathrm{Fe}$ and ${ }^{58} \mathrm{Fe} /{ }^{56} \mathrm{Fe}$ ratios was $1.14 \%$ and $1.55 \%$, respectively. The average enrichment value (mean $\pm S E M)$ was $4.71 \pm 0.41 \%$ for the 
${ }^{57} \mathrm{Fe} /{ }^{56} \mathrm{Fe}$ ratio $(\mathrm{n}=32)$ and amounted $4.51 \pm 0.20 \%$ for the ${ }^{58} \mathrm{Fe} /{ }^{56} \mathrm{Fe}$ ratio $(\mathrm{n}=31)$.

Table 1 Fe status of the group of subjects ${ }^{1}$

\begin{tabular}{lcccc}
\hline Fe-status & $0 \mathrm{~g} \mathrm{Lf}$ & $0.5 \mathrm{~g} \mathrm{Lf}$ & $2.0 \mathrm{~g} \mathrm{Lf}$ & $5.5 \mathrm{~g} \mathrm{Lf}$ \\
\hline $\mathrm{Hb}(\mathrm{mmol} / \mathrm{L})$ & 7.7 & 7.6 & 8.0 & 7.9 \\
& $(7.1-8.3)$ & $(7.0-8.5)$ & $(7.5-8.6)$ & $(7.5-8.4)$ \\
Ferritin $(\mu \mathrm{g} / \mathrm{L})$ & 8.6 & 7.0 & 7.0 & 6.2 \\
& $(3.6-16.8)$ & $(3.1-11.2)$ & $(3.5-12.5)$ & $(3.3-13.3)$ \\
$\mathrm{Tf}$ saturation $(\%)$ & 17.0 & 19.5 & 13.4 & 17.0 \\
& $(7.4-40.7)$ & $(5.7-42.6)$ & $(7.0-19.9)$ & $(8.3-37.7)$ \\
$\mathrm{TIBC}(\mu \mathrm{mol} / \mathrm{L})$ & 76.8 & 80.0 & 80.1 & 76.7 \\
& $(58.4-104.8)$ & $(60.2-96.7)$ & $(58.0-105.1)$ & $(59.4-100.0)$ \\
\hline
\end{tabular}

'Values are expressed as mean (range); $\mathrm{n}=8$

Table 2 The enrichment of the ${ }^{57} \mathrm{Fe} /{ }^{56} \mathrm{Fe}$ and ${ }^{58} \mathrm{Fe} /{ }^{56} \mathrm{Fe}$ ratio and the subjects' total ${ }^{56} \mathrm{Fe}$ mass. The percentage recovery of the intravenously administered ${ }^{58} \mathrm{Fe}$ indicates incorporation of iron into erythrocytes ${ }^{1}$

\begin{tabular}{|c|c|c|c|c|}
\hline & $0 \mathrm{~g} \mathrm{Lf}$ & $0.5 \mathrm{~g} \mathrm{Lf}$ & $2 \mathrm{gLf}$ & $5.5 \mathrm{~g} \mathrm{Lf}$ \\
\hline $\begin{array}{l}\text { Enrichment of } \\
{ }^{57} \mathrm{Fe} /{ }^{6} \mathrm{Fe}(\%)\end{array}$ & $\begin{array}{r}4.3 \pm 0.9 \\
(0.9-8.2)\end{array}$ & $\begin{array}{c}5.1 \pm 1.0 \\
(2.4-10.8)\end{array}$ & $\begin{array}{r}4.7 \pm 0.6 \\
(1.0-6.5)\end{array}$ & $\begin{array}{r}4.8 \pm 0.9 \\
(1.8-9.7)\end{array}$ \\
\hline $\begin{array}{l}\text { Enrichment of } \\
{ }^{58} \mathrm{Fe} /{ }^{36} \mathrm{Fe}(\%)\end{array}$ & $\begin{array}{l}4.6 \pm 0.4^{2} \\
(3.3-6.3)\end{array}$ & $\begin{array}{c}4.8 \pm 0.5 \\
(2.0-6.4)\end{array}$ & $\begin{array}{c}4.1 \pm 0.3 \\
(2.4-4.9)\end{array}$ & $\begin{array}{l}4.7 \pm 0.4 \\
(3.4-6.3)\end{array}$ \\
\hline Total ${ }^{56} \mathrm{Fe}$ mass (mg) & $\begin{array}{c}1461 \pm 77 \\
(1179-1775)\end{array}$ & $\begin{array}{c}1430 \pm 56 \\
(1260-1657)\end{array}$ & $\begin{array}{c}1524 \pm 50 \\
(1358-1748)\end{array}$ & $\begin{array}{c}1504 \pm 80 \\
(1254-1867)\end{array}$ \\
\hline${ }^{58} \mathrm{Fe}$ recovery $(\%)$ & $\begin{array}{l}70 \pm 5^{2} \\
(44-80)\end{array}$ & $\begin{array}{c}71 \pm 7 \\
(29-99)\end{array}$ & $\begin{array}{c}64 \pm 3 \\
(46-74)\end{array}$ & $\begin{array}{l}75 \pm 8 \\
(40-116)\end{array}$ \\
\hline
\end{tabular}


Table 2 shows the enrichment of the ${ }^{57} \mathrm{Fe} /{ }^{56} \mathrm{Fe}$ and ${ }^{58} \mathrm{Fe} /{ }^{56} \mathrm{Fe}$ ratios, the total ${ }^{56} \mathrm{Fe}$ mass, the percentage of recovery of the intravenous ${ }^{58} \mathrm{Fe}$ indicating the incorporation of absorbed Fe into erythrocytes calculated from the enrichment of ${ }^{58} \mathrm{Fe}$ and total ${ }^{56} \mathrm{Fe}$ mass. One of the subjects, who was an endurance runner and the only sportswoman, showed low recovery percentage during the whole study (mean value was $46 \%$ compared to $>71 \%$ for the other subjects). Table 3 shows the individual absorption percentages for each treatment, calculated from the enrichment of the ${ }^{57} \mathrm{Fe} /{ }^{56} \mathrm{Fe}$ and ${ }^{58} \mathrm{Fe} /{ }^{56} \mathrm{Fe}$ ratios in erythrocytes. No significant differences were found between the different treatment means $(\mathrm{P}=0.9$ ). Also, no significant difference was found between the different treatment means when corrected for Fe status parameters or menstruation during the test days.

Table 3 Percentage absorption of $\mathrm{Fe}$ calculated from the enrichment of ${ }^{57} \mathrm{Fe} /{ }^{56} \mathrm{Fe}$ and ${ }^{58} \mathrm{Fe} /{ }^{56} \mathrm{Fe}$ in erythrocytes

\begin{tabular}{crrrr}
\hline Subject & \multicolumn{1}{c}{$0 \mathrm{~g} \mathrm{Lf}$} & $0.5 \mathrm{~g} \mathrm{Lf}$ & $2 \mathrm{~g} \mathrm{Lf}$ & $5.5 \mathrm{~g} \mathrm{Lf}$ \\
\hline 1 & 5.2 & 8.5 & 19.9 & 26.3 \\
2 & 10.8 & 7.1 & 14.1 & 6.6 \\
3 & 22.3 & 11.8 & 23.2 & 18.6 \\
4 & 11.1 & 6.5 & 3.5 & 9.0 \\
5 & 2.4 & 34.6 & 26.7 & 38.7 \\
6 & 11.3 & 31.8 & 27.1 & 11.7 \\
7 & 27.1 & 13.7 & 18.1 & 4.3 \\
8 & 38.6 & 40.7 & 18.1 & 27.7 \\
\hline Mean \pm SEM & $16.1 \pm 4.3$ & $19.3 \pm 4.9$ & $18.8 \pm 2.7$ & $17.9 \pm 4.3$ \\
\hline
\end{tabular}

Between mean overall Fe absorption per subject over the 4 treatments and mean overall serum ferritin no significant correlation was found. When the correlation was calculated within treatments separately, it was only significant during the control treatment $(\mathrm{r}=-0.75, \mathrm{P}<0.05)$. 


\section{Discussion}

Measurement of $\mathrm{Fe}$ absorpion using two stable isotopes of iron $\left({ }^{58} \mathrm{Fe}\right.$ and $\left.{ }^{57} \mathrm{Fe}\right)$ and two routes of delivery (intravenous and oral) was described by Barrett et al [1].]. They found in women an average intravenous incorporation of Fe into erythrocytes of $81 \%$ (range $68-93 \%$ ) and an average oral Fe absorption of $20 \%(10-34 \%)$. Their results compare favorably with our results, with respect to absorption, despite the fact that in their study only one of the five women had serum ferritin levels below $20 \mu \mathrm{g} / \mathrm{l}$. A possible explanation for our relatively low absorption rate may be the inclusion of a meal with the test drinks, as it is known that food inhibits Fe absorption [18]. In one occasion we estimated the recovery of ${ }^{58} \mathrm{Fe}$ on more than $100 \%$, but in this case the enrichment of ${ }^{58} \mathrm{Fe} /{ }^{56} \mathrm{Fe}$ was not extremely high compared to the other enrichments and therefore the high recovery could be due to a higher estimated total ${ }^{56} \mathrm{Fe}$ mass than the actual ${ }^{56} \mathrm{Fe}$ mass.

A wide inter- and intra-subject variation was found, which makes it difficult to determine to what extent differences in absorption are related to changes in diet or to, for instance, the Fe status of the subject. Large differences in absorption between subjects have also been found in other studies [19, 20]. Mason et al [19] have found a weak inverse correlation between the previous day's Fe intake and ${ }^{58} \mathrm{Fe}$ absorption $(\mathrm{r}=-0.3, \mathrm{P}<0.05$ ), so this may partly explain the large differences in Fe absorption between and within subjects in the present study.

Based on the standard error of difference of $4.53 \%$, with the current method we would have been able to detect a difference in absorption between treatments of $7.7 \%$ $(P=0.05$, one-sided $)$ or of $9.5 \%(P=0.05$, two-sided $)$. Other studies in Fe deficient volunteers did show such treatment differences in Fe absorption, determined by other methods. For example, Ekman \& Reizenstein [21] compared absorption of haem Fe $($ mean $\pm \mathrm{SD}, 22.03 \pm 8.9 \%$ ) with non-haem Fe (mean $\pm \mathrm{SD}, 9.45 \pm 7.8 \%)$. Also Kaltwasser et al [22] found a difference $>9.5 \%$ between the bioavailability of ferrous (mean $\pm \mathrm{SD}, 43.7 \pm 7.1 \%$ ) and ferric $\mathrm{Fe}$ (mean $\pm \mathrm{SD}, 8.8 \pm 4.7 \%$ ). Ferrous $\mathrm{Fe}$ is not very stable in solution and is easily reduced to the insoluble form. It is known that $\mathrm{Lf}$ binds $\mathrm{Fe}^{3+}$, thereby stabilizing $\mathrm{Fe}$ in solution $[23,24]$. In our study we reduced ferric Fe to ferrous $\mathrm{Fe}$ by adding vitamin $\mathrm{C}$, a well-known enhancer of non-haem $\mathrm{Fe}$ uptake. 
So one might argue that this reduction of $\mathrm{Fe}^{3+}$ makes the role of $\mathrm{Lf}$ superfluous or even prevents the binding of Fe to $L f$ and thus discourages the potential role of Lf to increase $\mathrm{Fe}$ absorption. However, breast milk probably also contains Fe only in the ferrous form because of the large amount of vitamin $\mathrm{C}$ present. So, if $\mathrm{Lf}$ increases $\mathrm{Fe}$ absorption from breastmilk this enhancing effect is also valid for $\mathrm{Fe}^{2+}$.

We found an inverse correlation between serum ferritin and Fe absorption during the control treatment, similar to other studies in which stable isotopes or other methodology to measure Fe absorption were used $[11,25,26]$. During the Lf treatment a negative correlation was not shown. We have no satisfactory explanation for the absence of this negative correlation during the Lf treatments. On the other hand, Hunt et al [27] also did not find a correlation between Fe absorption and ferritin when investigating the effect of vitamin $\mathrm{C}$ on apparent $\mathrm{Fe}$ absorption in women with the same narrow range of low serum ferritin values.

Other studies in adult subjects have failed to show that human $\mathrm{Lf}$ increases $\mathrm{Fe}$ absorption [28, 29]. In one of these studies [29] co-administration of Lf and radioactive $\mathrm{Fe}$ resulted in a lower plasma radioactivity for up to $3 \mathrm{~h}$ following duodenal administration. However, it should be pointed out that these studies were carried out in subjects with adequate Fe stores.

The rationale to use human instead of bovine Lf for Fe absorption would be that human enterocytes may not bind, or bind less effectively, bovine Lf. This issue of species specific receptor binding is still controversial and appears to be dependent of the model system chosen. Cox et al [30] showed that human Lf can donate Fe to pieces of human small intestinal mucosa, whereas in this regard bovine Lf had reduced activity and human transferrin had no activity at all. A number of studies have made use of brush border membranes and clearly found evidence for species specificity $[2,3,31]$. On the other hand, tissue culture cell studies have clearly shown that bovine Lf will bind to human intestinal cells and/or is able to displace human Lf from the receptor site $[4,32]$.

Another issue that deserves attention is the fact that the adult digestive system is more developed than in the newborn. Both acid production and pepsin production in newborn infants and young animals are low in relation to body weight compared with 
adult levels, and increase slowly with age. Concomitantly, the digestive ability increases with age [33]. It is thus possible that Lf in adults is partly denaturated by gastric juice, and therefore looses its Fe-binding capacity and/or receptor binding sites. In agreement with this line of reasoning is the fact that the animal experiments with bovine Lf, showing stimulation of Fe metabolism, were all carried out in young rapidly growing Fe-deficient animals (mice, piglets, rats). However, De Vet \& van Gool [29], who brought the test solution directly through a tube into the duodenum of subjects with adequate $\mathrm{Fe}$ stores in order to prevent denaturation of $\mathrm{Lf}$ by gastric juice, found a negative effect of $\mathrm{Lf}$ on absorption. In healthy babies in whom ingested Lf is not completely destroyed and thus keeps its ability to bind $\mathrm{Fe}$ in the small intestine [34], no effect or an inhibiting effect on $\mathrm{Fe}$ availability was found [35-37]. In the study of Chierici et al [38] it took $90 \mathrm{~d}$ of feeding to show higher serum ferritin levels in healthy infants receiving formula supplemented with $100 \mathrm{mg}$ of bovine $\mathrm{Lf} / 100 \mathrm{ml}$ than in infants receiving formula without Lf. Again it should be pointed out that these human studies were all carried out in Fe-repleted subjects.

In conclusion, our study did not show an effect of bovine $\mathrm{Lf}$ on $\mathrm{Fe}$ absorption in women with low $\mathrm{Fe}$ stores. However, we cannot exclude the possibility that we have missed small treatment effects (an increase in absorption of less than about $8 \%$ ) due to the high within-subject variability in true intestinal Fe absorption. Furthermore it cannot be excluded that the absence of an effect is due to species specificity or proteolytic breakdown with resulting loss of functionality. Further research into the role of bovine $\mathrm{Lf}$ in human adults with $\mathrm{Fe}$ deficiency is warranted.

\section{References}

1 Masson PL \& Heremans JF. Lactoferrin in milk from different species. Comp Biochem Physiol 1971;39b:119-129.

2 Davidson LA \& Lönnerdal B. Fe-saturation and proteolysis of human lactoferrin: effect on brush-border receptor-mediated uptake of Fe and Mn. Am J Physiol 1989;257:G930-G934.

3 Kawakami H. \& Lonnerdal B. Isolation and function of a receptor for human lactoferrin in human fetal intestinal brush-border membranes. Am J Physiol 1991;261:G841-G846.

4 Spik G, Legrand D, Leveugle B, Mazurier J, Mikogami T, Montreuil J, Pierce A \& Rochard E. Binding properties of different lactoferrins to human lactotransferrin receptor. In: New perspectives in infant nutrition. Renner $\mathrm{B}$, Sawatziki $\mathrm{G}$, eds. New York: Thileme Medical Publishers Inc. 1993:78-83. 
5 Mikogami $T$, Marianne $T$ \& Spik $G$. Effect of intracellular iron depletion by picolinic acid on expression of the lactoferrin receptor in the human colon carcinoma cell subclone HT29-18-C1. Biachem I 1995;308:391-397.

6 Fransson GB, Keen CL \& Lönnerdal B. Supplementation of milk with iron bound to lactoferrin using weanling mice: L. Effects on hematology and tissue iron. J Pediatr Gastroenterol Nutr $1983 ; 2: 693-700$.

7 Fransson GB, Thorén-Tolling $K$, Jones $B$, Hambraeus L \& Lönnerdal B. Absorption of lactoferrin-iron in suckling pigs. Nutr Res 1983;3;373-384.

8 Kume $\mathbf{S} \&$ Tanabe $S$. Effect of supplemental lactoferrin with ferrous iron on iron status of newborn calves. I Dairy Sci 1996;79:459-464.

9 Kawakami H. Hiratsuka M \& Dosako S. Effects of iron-saturated lactoferrin on iron absorption. Agric Biol Chem 1988;52:903-908.

10 Nutritional Education Board. Result national Dutch food consumption surveys, 1992. Meppel: Ten Brink, 1993.

11 Barrett JF, Whittaker PG, Williams JG \& Lind $T$. Absorption of non-haem iron in normal women measured by the incorporation of two stable isotopes into erythrocytes. Clin Sci 1992,83:213-219.

12 Nevo Foundation Editorial Board. Food composition table 1993-1994. The Hague: Krips Repro, 1994.

$13 \mathrm{Kim}$ I, Yetley EA \& Calwo MS. Variations in iron-status measures during the menstrual cycle. Am J Clin Nutr 1993;58:705-709.

14 Luten $J B$, Muijs $T$ \& Van Dokkum W. The determination of stable isotope ratio of zinc, copper, iron in faeces and calcium in urine by ICP-MS. In: Bioavailability '93. Nutritional, chemical and food processing implications of nutrient availability. Schlemmer $U$, ed. Karlsruhe: Bundesforschungsanstalt für Ernährung, 1993:161-168.

15 Gray AL \& Williams JG. System optimisation of the effect on polyatomic, oxide and double charged ion response of a commercial inductively coupled plasma mass spectrometry instrument. I Anal At Spectrom 1987;2:599-606.

16 Genstat 5 Committee. Genstat five release three reference manual. New York: Oxford University Press, 1994.

17 Fairweather-Tait S. Tron. Int J Vitam Nutr Res 1993;63:296-301.

18 Cook JD, Dassenko S \& Skikne BS. Serum transferrin receptor as an index of iron absorption. Bir J Hathatol 1990;75:603-609.

19 Mason PM, Judd PA, Fairweather-Tait SJ, Eagles J \& Minski MJ. The effect of moderately increased intakes of complex carbohydrates (cereals, vegetables and fruit) for 12 weeks on iron and zinc metabolism. Br J Nutr 1990;63:597-611.

20 Fairweather-Tait SJ, Johnson A, Eagles J, Ganatra S, Kennedy H \& Gurr MI. Studies on calcium absorption from milk using a double-label stable isotope technique. Br $J$ Nutr $1989 ; 62: 379-388$.

21 Ekman $M$ \& Reizenstein P. Comparative absorption of ferrous and heme-iron with meals in nomal and iron deficient subjects. Z Emahrungswiss 1993;32:67-70.

22 Kaltwasser JP, Werner E \& Niechzial $\mathrm{M}_{*}$ Bioavailability and therapeutic efficacy of bivalent and trivalent iron preperations. Drug Res 1987;37-1:122-129. 
23 Nagasako $Y$, Saito H, Tamura Y, Shimamura S \& Tomita M. Iron-binding properties of bovine lactoferrin in iron-rich solution. J Dairy Sci 1993;76:1876-1881.

24 Kawakami H, Dosako S \& Nakajima I. Effect of lactoferrin on iron solubility under neutral conditions. Biosci Biotech Biochem 1993;57:1376-1377.

25 Cook JD, Dassenko SA \& Lynch SR. Assessment of the role of nonherne-iron availability in iron balance. Am J Clin Nutr 1991;54:717-722.

26 Hultén L, Gramatkovski E, Gleenup A \& Hallberg L. Iron absorption from the whole diet. Relation to meal composition, iron requirements and iron stores. Eur $J$ Clin Nutr 1995;49:794-808.

27 Hunt JR, Gallagher SK \& Johnson LK. Effect of ascorbic acid on apparent iron absorption by women with low iron stores. Am J Clin Nutr 1994;59:1381-1385.

28 McMillan JA, Oski FA, Lourie G, Tomarelli RM \& Landaw SA. Iron absorption from human milk, simulated human milk, and proprietary formulas. Pediatrics 1977;60:896-900.

29 de Vet BJ \& van Gool. J. Lactoferrin and iron absorption in the small intestine. Acta Med Scand 1974:196:393-402.

30 Cox TM, Mazurier J, Spik G, Montreuil J \& Peters TJ. Iron binding proteins and influx of iron across the duodenal brush border. Evidence for specific lactotransferrin receptors in the human intestine. Biochim Biophys Acta 1979;588:120-128.

31 Gislason J, Lyer S, Hutchens W \& Lönnerdal B. Lactoferrin receptors in piglet small intestine: lactoferrin binding properties, ontogeny, and regional distribution in the gastrointestinal tract. $J$ Nutr Biochem 1993;4:528-533.

32 Oguchi S, Walker WA \& Sanderson IR. Iron saturation alters the effect of lactoferrin on the proliferation and differentiation of human enterocytes (Caco-2 cells). Biol Neonate 1995;67:330-339.

33 Brock JH. Lactoferrin in human milk: its role in iron absorption and protection against enteric infection in the newborn infant. Arch Dis Child 1980;55:417-421.

34 Spik G, Brunet B, Mazurier-Dehaine C, Fontaine G \& Montreuil J. Characterization and properties of the human and bovine lactotransferrins extracted from the faleces of newborn infants. Acta Paediatr Scand 1982;71:979-985.

35 Fairweather-Tait SJ, Balmer SE, Scott PH \& Minski MJ. Lactoferrin and iron absorption in newborn infants. Pediatr Res 1987;22:651-654.

36 Schuiz-Lell G, Domer K, Oldigs HD, Sievers $\mathbb{E} \&$ Schaub J. Iron availability from an infant formula supplemented with bovine lactoferrin. Acta Paediatr Scand 1991;80:155-158.

37 Davidsson L, Kastenmayer P, Yuen M, Lönnerdal B \& Hurrell RF. Influence of lactoferrin on iron absorption from human milk in infants. Pediatr Res 1994;35:1 17-124.

38 Chierici R, Sawatzki G, Tamisari L, Volpato S \& Vigi V. Supplementation of an adapted formula with bovine lactoferrin. 2. Effects on serum iron, ferritin and zinc levels. Acta Paediatr $1992 ; 81: 475-479$. 


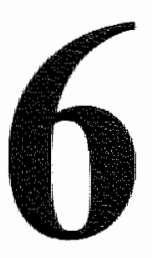

\section{Non-digestible}

oligosaccharides

do

not

\section{interfere with calcium and non-haem iron absorption in young healthy men}

Ellen GHM van den Heuvel, Gertjan Schaafsma, Theo Muijs and Wim van Dokkum American Journal of Clinical Nutrition 1998;67:412-420.

\section{Abstract}

The effect of inulin, fructo-oligosaccharides (FOS) and galacto-oligosaccharides (GOS) on true intestinal absorption of iron and calcium was measured in men using dual stable isotope techniques (oral ${ }^{57} \mathrm{Fe}$ and ${ }^{44} \mathrm{Ca}$ and intravenous ${ }^{58} \mathrm{Fe}$ and ${ }^{48} \mathrm{Ca}$ ). The incorporation of iron isotopes into erythrocytes and the urinary excretion of calcium isotopes was measured using an inductively coupled plasma mass spectrometer. Twelve healthy, non-anemic male subjects (aged 20 to 30 ) received 4 treatments consisting of a constant basal diet either supplemented with $15 \mathrm{~g} /$ day of inulin, FOS, or GOS, or not supplemented (control treatment). These 4 treatments were given for 21 days each according to a randomized cross-over design. Iron absorption was measured over the last 7 days (days 15-21) and calcium absorption was measured on day 21 of each treatment period. During the treatment with inulin, FOS, GOS, or the control treatment mean $( \pm \mathrm{SEM})$ iron absorption was $5.5 \pm 1.6 \%, 6.1 \pm 1.9 \%$, $5.3 \pm 1.9 \%$, and $5.1 \pm 1.5 \%$, respectively. Mean $( \pm$ SEM) calcium absorption was $25.8 \pm 2.3 \%, 26.3 \pm 1.9 \%, 26.3 \pm 2.6 \%$, and $28.1 \pm 4.3 \%$, respectively. None of the differences between treatments reached statistical significance. It is concluded that $15 \mathrm{~g}$ of inulin, FOS, or GOS per day does not have a negative effect on Fe and Ca 
absorption in young healthy men.

\section{Introduction}

There is increasing interest in so-called functional foods or functional food ingredients, foods with an additional nutritional value which may be beneficial to health. Non-digestible oligosaccharides (NDO) may fit into this category of functional food ingredients. NDO are defined as "oligosaccharides that escape digestion in the stomach and small intestine of humans and consequently arrive quantitatively in the colon". Examples are inulin and fructo-oligosaccharides (fructans from the chicory root), and galacto-oligosaccharides. Favorable effects of the ingestion of NDO on gastrointestinal function (fecal bulking, production of shortchain fatty acids) as well as on metabolism (reduction of serum cholesterol, improved tolerance to glucose) have been found [1].

Before NDO can be considered as favorable for health, its effect on calcium or iron metabolism should be established in humans. An adequate supply and bioavailability of calcium ( $\mathrm{Ca}$ ) is essential to attain maximum bone mass, upon which the adult bone mass depends [2]. Many studies have also shown a significant relationship between iron (Fe) status and consumption of foods known to influence Fe absorption [3]. Therefore, a fundamental understanding of dietary factors affecting availability of $\mathrm{Fe}$ and $\mathrm{Ca}$ for absorption is needed to optimize both $\mathrm{Fe}$ and $\mathrm{Ca}$ nutrition.

In rats positive effects of NDO on $\mathrm{Fe}$ and $\mathrm{Ca}$ absorption have been found [4-9]. The results of a few human studies on other non-digestible and fermentable carbohydrates (gums and pectins) indicate that with the possible exception of Fe, pectin and gums do not adversely affect mineral balance $[10,11]$. The bioavailability of Fe has been shown to be decreased by pectin in some, but not all, human studies [10]. Ca showed the greatest potential for negative balance with longer locust bean gum consumption [12].

Like soluble dietary fiber (gums and some pectins), NDO are substrates for both hydrolysis and fermentation by cecal and colonic microflora. As a consequence of fermentation, the large intestinal pool of short-chain fatty acids (SCFA) and other organic acids increases and the $\mathrm{pH}$ may decrease. These environmental changes in the 
large intestine may improve solubility and absorption of several minerals and trace elements. Moreover, it is possible that NDO forms complexes with minerals in the small intestine, which could either promote or decrease their absorption.

The aim of this study was to investigate the effect of $15 \mathrm{~g}$ of inulin, fructooligosaccharides (FOS) and galacto-oligosaccharides (GOS) on the absorption of Fe and $\mathrm{Ca}$ in humans. A supplement of $15 \mathrm{~g}$ of NDO to the diet is feasible by using NDO-enriched products and raises substantially the total amount of NDO in the diet (from about 4 to $19 \mathrm{~g}$ per day) without bringing about symptoms of intolerance, since the first symptoms of intolerance (excessive flatus) are expected above $30 \mathrm{~g}$ of NDO per day [13]. True absorption of $\mathrm{Fe}$ and $\mathrm{Ca}$ was determined using the dual stable isotope techniques, by measuring the incorporation of Fe isotopes into haemoglobin or the excretion of $\mathrm{Ca}$ isotopes in urine collected over the $\mu$ after isotope administration. Also fecal $\mathrm{pH}$ and the fecal output of SCFA were measured, as these parameters could be involved in the mechanism by which NDO influence $\mathrm{Fe}$ or $\mathrm{Ca}$ absorption.

\section{Subjects and methods}

\section{Subjects}

This study was part of a larger study in which the effect of NDO on blood glucose, blood lipids, breath $\mathrm{H}_{2}$ excretion and also on some fecal parameters was measured. To avoid inhomogeneity of these variables 12 healthy male subjects aged 20 to 30 were selected for the study (body weight (mean \pm SD) $79.8 \pm 9.2 \mathrm{~kg}$, height $186 \pm 6.1$ $\mathrm{cm})$. Normal health was assessed at pre-study screening. This included a medical history, physical examination, measurement of blood pressure and heart rate, electrocardiography and routine clinical laboratory tests. Only subjects reporting a typical Dutch food pattern [14] and normal bowel habits were selected. None of the subjects were taking dietary supplements and all were non-smokers. The study protocol was approved by the TNO external Medical Ethics Committee and all subjects signed informed consent forms. 


\section{Isotope methods}

The dual stable isotope technique involves the administration of two isotopes, one orally $\left({ }^{57} \mathrm{Fe}\right.$ and $\left.{ }^{44} \mathrm{Ca}\right)$ and one intravenously ( ${ }^{58} \mathrm{Fe}$ and ${ }^{48 \mathrm{Ca}}$. Then the incorporation of $\mathrm{Fe}$ isotopes into erythrocytes and the excretion of $\mathrm{Ca}$ isotopes into urine collected after isotope administration is measured. Blood was analyzed for both ${ }^{57} \mathrm{Fe} /{ }^{56} \mathrm{Fe}$ and ${ }^{58} \mathrm{Fe} /{ }^{56} \mathrm{Fe}$ ratios and urine was analyzed for both ${ }^{44} \mathrm{Ca} /{ }^{43} \mathrm{Ca}$ and ${ }^{48} \mathrm{Ca} /{ }^{43} \mathrm{Ca}$ ratios to correct for isotope fractionation. Taking the amount administered and the natural abundances of these isotopes into account, true fractional absorption of Fe [15] and Ca [16] can be calculated.

\section{Preparation of stable isotope solutions}

Stable $\mathrm{Fe}$ and $\mathrm{Ca}$ isotopes were obtained from Eurisotop (Saint Aubin Cedex, France), in the form of $\mathrm{Fe}$ oxide and $\mathrm{Ca}$ carbonate. The abundances of the different Fe isotopes according to ICP-MS analyses were: Fe enriched in ${ }^{57} \mathrm{Fe}, 0 \%{ }^{54} \mathrm{Fe}, 3.6 \%$ ${ }^{56} \mathrm{Fe}, 95.5 \%{ }^{57} \mathrm{Fe}$, and $0.9 \%{ }^{58} \mathrm{Fe}$, and $\mathrm{Fe}$ enriched in ${ }^{58} \mathrm{Fe}, 0 \%{ }^{54} \mathrm{Fe}, 0.45 \%{ }^{56} \mathrm{Fe}, 6.5 \%$ ${ }^{57} \mathrm{Fe}$, and $93.05 \%{ }^{58} \mathrm{Fe}$. The natural abundances of $\mathrm{Fe}$ isotopes are $5.8 \%{ }^{54} \mathrm{Fe}, 91.72 \%$ ${ }^{56} \mathrm{Fe}, 2.2 \%{ }^{57} \mathrm{Fe}$, and $0.28 \%{ }^{58} \mathrm{Fe}[17]$.

Under sterile conditions $\mathrm{Fe}_{2} \mathrm{O}_{3}$ was dissolved in $10.2 \mathrm{M} \mathrm{HCl}$ and $14.5 \mathrm{M} \mathrm{HNO}_{3}$, followed by the addition of $0.5 \mathrm{M} \mathrm{H}_{2} \mathrm{SO}_{4}$. The solution was then heated for $30 \mathrm{~min}$ at both 230 and $250{ }^{\circ} \mathrm{C}$ followed by cooling. The white powder was redissolved in 0.2 $\mathrm{M} \mathrm{H}_{2} \mathrm{SO}_{4}$ and filtered through a $0.5 \mu \mathrm{m}$ Teflon filter [18]. Vitamin $\mathrm{C}$, to reduce ferric into ferrous $\mathrm{Fe}$, and deaerated, deionized water (final concentration $3 \mathrm{mg} / \mathrm{ml}$ of vitamin C) were added [15]. The final concentration of Fe was $0.924 \mathrm{mg} / \mathrm{ml}$ of enriched ${ }^{57} \mathrm{Fe}$ and $0.112 \mathrm{mg} / \mathrm{ml}$ of enriched ${ }^{58} \mathrm{Fe}$. The final $\mathrm{pH}$ of the intravenous ${ }^{58} \mathrm{Fe}$ solution was 1.7 .

The abundances of the different $\mathrm{Ca}$ isotopes according to ICP-MS analysis were: $\mathrm{Ca}$ enriched in ${ }^{44} \mathrm{Ca} 2.80 \%{ }^{40} \mathrm{Ca}, 0.05 \%{ }^{42} \mathrm{Ca}, 0.02 \%{ }^{43} \mathrm{Ca}, 97.10 \pm 0.2 \%{ }^{44} \mathrm{Ca},<0.002 \%$ ${ }^{46} \mathrm{Ca}$, and $0.03 \%{ }^{48} \mathrm{Ca}$, and Ca enriched in ${ }^{48} \mathrm{Ca}, 8.96 \%{ }^{40} \mathrm{Ca}, 0.09 \%{ }^{42} \mathrm{Ca}, 0.02 \%{ }^{43} \mathrm{Ca}$, $0.24 \%{ }^{44} \mathrm{Ca},<0.01 \%{ }^{46} \mathrm{Ca}$, and $90.69 \%{ }^{48} \mathrm{Ca}$. The natural abundances of $\mathrm{Ca}$ are $96.941 \%{ }^{40} \mathrm{Ca}, 0.647 \%{ }^{42} \mathrm{Ca}, 0.135 \%{ }^{43} \mathrm{Ca}, 2.086 \%{ }^{44} \mathrm{Ca}, 0.004 \%{ }^{46} \mathrm{Ca}$, and $0.187 \%$ ${ }^{48} \mathrm{Ca}[17] .{ }^{44} \mathrm{Ca}$ carbonate was converted into chloricle salt, diluted with deionized 
water, followed by $\mathrm{pH}$ adjustment to 5 . A similar procedure was followed for ${ }^{48} \mathrm{Ca}$ carbonate, except that saline was used instead of deionized water. After filtration the solution was distributed over $10 \mathrm{ml}$ sterilization bottles and autoclaved for $20 \mathrm{~min}$ [16]. The final concentration was $1.2 \mathrm{mg} / \mathrm{ml}$ enriched ${ }^{44} \mathrm{Ca}$ for the oral ${ }^{44} \mathrm{Ca}$ solution and $0.12 \mathrm{mg} / \mathrm{ml}$ enriched ${ }^{48} \mathrm{Ca}$ for the intravenous ${ }^{48} \mathrm{Ca}$ solution.

Table 1 Composition of the NDO supplements (\%)

\begin{tabular}{lccc}
\hline & Inulin & FOS & GOS \\
\hline Oligo-fructose & 92 & 95 & 0 \\
Oligo-galactose & 0 & 0 & 85.7 \\
Glucose/fructose/sucrose & 8 & 5 & 3.3 \\
Galactose & 0 & 0 & 0.3 \\
Lactose & 0 & 0 & 10.7 \\
Ash & $<0.2$ & $<0.2$ & 1 \\
Degree of polymerisation (range) & $2-60$ & $2-8$ & $2-6$ \\
\hline
\end{tabular}

Study design and execution of the study

The subjects had a controlled diet consisting of a basal diet supplemented with $15 \mathrm{~g}$ of inulin, FOS, or GOS, or no added NDO, per day ( $5 \mathrm{~g}$ during each meal). As the pure oligosaccharide content of the supplements was not $100 \%$ (see Table 1), the weight of the individual NDO was adjusted for a constant intake of $15 \mathrm{~g}$ of pure oligosaccharides. These 4 treatments of 21 days each were given to the subjects according to a randomized cross-over design. This strictly controlled study was executed in a 'double-blind" mode. Table 2 shows the composition of the basal diet. The analyses were performed on freeze-dried samples of the diet. Protein content was determined according to Kjeldahl. The percentage of crude fat was analyzed according to Weibull-Stoldt [19]. Total carbohydrates were determined according to Van de Kamer [20]. Total dietary fiber was analyzed according to Prosky et al [21]. Fe was measured with a flame atomic absorption spectrometer at $248.3 \mathrm{~nm}$ wavelength with deuterium background compensation, and $\mathrm{Ca}$ at $422.7 \mathrm{~nm}$ wavelength. 
Table 2 Composition of the daily basal diet without NDO

\begin{tabular}{lc}
\hline Nutrients & Basal diet \\
\hline Total energy $(\mathrm{MJ})$ & 12.1 \\
From protein $(\%)$ & 11.3 \\
From fat $(\%)$ & 34.4 \\
From carbohydrates $(\%)$ & 54.3 \\
Dietary fiber $(\mathrm{g})$ & 25.0 \\
Calcium $(\mathrm{mg})$ & 955 \\
Iron $(\mathrm{mg})$ & 11.8 \\
\hline
\end{tabular}

During the first 2 weeks of each treatment period the subjects lived in their own environment and consumed at home the diet supplied, except for dinner which was consumed in the Institute's metabolic unit. In the last week (days 15-21) of each treatment period the subjects were housed in the metabolic unit. The $\mathrm{NDO}(5 \mathrm{~g})$ were added to $100 \mathrm{ml}$ of orange juice, which was consumed at the start of breakfast, lunch and dinner during the whole study. Body weight loss was corrected for by supplying extra soft drinks and/or cake, if necessary.

After an overnight fast, the subjects attended the research unit at day 15 of each treatment period. A blood sample of $20 \mathrm{ml}$ was taken and $10 \mathrm{ml}$ was put in a lithium heparin tube for the measurement of basal $\mathrm{Fe}$ isotope ratios. The remainder was divided over sample tubes for measurement of the subject's hemoglobin level, serum ferritin concentration and transferrin saturation (i.e. serum Fe/total Fe-binding capacity $x$ 100). Hemoglobin was determined with a Sysmex K-1000 Hematology Analyzer (Toa Medical Electronics, Japan). Serum ferritin was measured by enzyme immunoassay (sandwich) using a AIA-600 (TOSOH Corporation, Japan). Serum Fe was measured with FerroZine without deproteinization. Total Fe-binding capacity (TIBC) was determined by saturating transferrin with excess of $\mathrm{Fe}^{3+}$ ions, followed by the addition of magnesium carbonate which removes all the Fe not bound to serum transferrin (Boehringer Mannheim GmbH Diagnostica, Germany).

During each treatment period feces were collected. After homogenization of a $48-\mathrm{h}$ fecal sample the $\mathrm{pH}$ was determined and the concentration of SCFA was measured by 
HPLC using a ion-exclusion column [22].

In addition to the $5 \mathrm{~g}$ of $\mathrm{NDO}, 2 \mathrm{ml}$ of ${ }^{57} \mathrm{FeSO}_{4}$ and $100 \mathrm{mg}$ of vitamin $\mathrm{C}$ were added to $100 \mathrm{ml}$ of orange juice, which increased the total amount of vitamin $\mathrm{C}$ to $136 \mathrm{mg}$. This isotope-enriched orange juice was consumed at the start of breakfast, lunch and dinner during the last 7 days (days 15-21) of each treatment period. Vitamin $\mathrm{C}$ was added to improve absorption so as to obtain detectable enrichment percentages of ${ }^{57} \mathrm{Fe} /{ }^{56} \mathrm{Fe}$. To compensate for the extra amount of $\mathrm{Fe}$, the Fe content of the basal diet in the last week of each treatment period was reduced from $12.7 \mathrm{mg}$ to $10.0 \mathrm{mg}$ of $\mathrm{Fe}$, mainly by changing the amount of meat products. Of this $10 \mathrm{mg}$ of $\mathrm{Fe}$ about $15 \%$ is haem-Fe as estimated from the Dutch Food Composition Table [23]. At days 20 and 21 during the first two treatment periods $2.5 \mathrm{ml}$ of ${ }^{58} \mathrm{FeSO}_{4}$ solution was given intravenously. The mean incorporation of absorbed $\mathrm{Fe}$, calculated from the enrichment of ${ }^{58} \mathrm{Fe}$ in erythrocytes, given in the first two treatment periods was used as an estimate for incorporation during the last two treatment periods. Erythropoiesis, one of the main factors that influence red cell incorporation was not measured. Iron status did not vary during the study. Since variations in red cell incorporation are relatively minor in normal subjects when compared to the wide range of iron absorption [24], it was assumed that the within-subject variation of the ${ }^{58} \mathrm{Fe}$ incorporation was low.

The quantity of isotopes given by each route, which was calculated by weighing the bottles or syringes before and after administration, varied between 37.02 and 37.74 mg of ${ }^{57} \mathrm{Fe}$ and between 0.94 and $1.04 \mathrm{mg}$ of ${ }^{58} \mathrm{Fe}$. Fifteen days after isotope administration, blood was sampled for measurement of enriched $\mathrm{Fe}$ isotope ratios in erythrocytes. During each subsequent treatment period another part of Fe isotopes was incorporated into erythrocytes, on top of the Fe isotopes incorporated during an earlier treatment period, as erythrocytes live about 110 days. Therefore, the enriched ratio of the earlier $\mathrm{Fe}$ absorption test represented also the basal ratio of the next $\mathrm{Fe}$ absorption test performed during the following treatment period. From the enrichment of the ${ }^{57} \mathrm{Fe} /{ }^{56} \mathrm{Fe}$ and ${ }^{58} \mathrm{Fe} /{ }^{56} \mathrm{Fe}$ ratios true fractional absorption was calculated according to the formula described by Barrett et al [15], in which absorption was adjusted for the small amount of ${ }^{57} \mathrm{Fe}$ present in the intravenous injection and 
conversely the small amount of ${ }^{58} \mathrm{Fe}$ present in the oral preparation.

On day 19 of each treatment period the subjects consumed in the morning the NDO, ${ }^{57} \mathrm{FeSO}_{4}$ - and vitamin $\mathrm{C}$-containing orange juice to which $15 \mathrm{ml}$ of ${ }^{44} \mathrm{CaCl}_{2}$ was added. After breakfast, which contained $513 \mathrm{mg} \mathrm{Ca}, 10 \mathrm{ml}$ of ${ }^{48} \mathrm{CaCl}_{2}$ was given intravenously. Before and after bolus injection blood pressure and heart rate were recorded for safety reasons. The exact quantity of isotopes given by each route, which was calculated by weighing the bottles or syringes before and after administration, varied between 16.8 and $18.8 \mathrm{mg}$ of ${ }^{44} \mathrm{Ca}$ and between 1.00 and $1.14 \mathrm{mg}$ of ${ }^{48} \mathrm{Ca}$. From the measurement of the ${ }^{44} \mathrm{Ca} /{ }^{43} \mathrm{Ca}$ and ${ }^{48} \mathrm{Ca} /{ }^{43} \mathrm{Ca}$ ratios in urine collected before dose administration and over the $24 \mathrm{~h}$ after dose administration, fractional $\mathrm{Ca}$ absorption was computed according to the formula reported by Van Dokkum et al [25].

\section{Stable isotope analysis}

The blood samples were prepared for the inductively coupled plasma mass spectrometric (ICP-MS) analysis of the stable isotope ratios ${ }^{57} \mathrm{Fe} /{ }^{56} \mathrm{Fe}$ and ${ }^{58} \mathrm{Fe} /{ }^{56} \mathrm{Fe} \mathrm{[26]}$. After destruction of the samples in a Teflon tube with concentrated nitric acid, the $\mathrm{pH}$ was adjusted to $3.0 \pm 0.5$ with ammonia. Fe was isolated by selective extraction with $1 \%$ sodium diethyldithiocarbamate (trihydrate) into $\mathrm{CCl}_{4}$. The water layer was rejected. The carbon tetrachoride layer was then left overnight with $10-20 \mathrm{ml} 1.4 \mathrm{~N}$ $\mathrm{HNO}_{3}$. The $\mathrm{HNO}_{3}$ layer was used for the ICP-MS (Perkin Elmer Sciex, Elan 500) measurement. All measurements were carried out in isotope ratio peak hopping mode. The ICP-MS was operated in the high resolution mode to provide maximal accuracy. Typical conditions for operations were: plasma power $1.2 \mathrm{~kW}$, reflected power $<5 \mathrm{~W}$, coolant Ar-flow rate $18 \mathrm{l} / \mathrm{min}$, dwell time $20 \mathrm{msec}, 1$ measurement per peak, 10 repeats per integration, total measuring time $270 \mathrm{sec}$.

The Fe concentration in the $\mathrm{HNO}_{3}$ solution was measured by atomic absorption spectrometry (AAS). If necessary, the solution was diluted to adjust the Fe concentration to ca. $1.0 \mu \mathrm{g} / \mathrm{ml}$ in order to avoid saturation of the detection system. ICP-MS plasma was optimized to reduce the possible molecular interference at $\mathrm{m} / \mathrm{z} 56$ of $\mathrm{ArO}^{+}[27]$. During each ICP-MS run, solutions of an Fe standard $(1.0 \mu \mathrm{g} / \mathrm{ml})$, blank, $\mathrm{HNO}_{3}$ and a blood sample were analyzed for the isotope ratios ${ }^{57} \mathrm{Fe} /{ }^{56} \mathrm{Fe}$ and ${ }^{58} \mathrm{Fe} /{ }^{56} \mathrm{Fe}$. The results 
of the samples were corrected for the small interference of $\mathrm{ArO}^{*}$ at ${ }^{56} \mathrm{Fe}$. Minor adjustments in bias were made for unknown factors by comparing standards with accepted natural abundances. All samples were measured in duplicate. Both the basal and the enriched ratio of one treatment were measured within one day.

$\mathrm{Ca}$ isotope ratios ${ }^{44} \mathrm{Ca} /{ }^{4} \mathrm{Ca}$ and ${ }^{4} \mathrm{Ca} /{ }^{4} \mathrm{Ca}$ in urine were measured by ICP-MS after protein precipitation with $3.5 \%$ trichloroacetic acid, precipitation of Ca with saturated ammoniumoxalate and dissolution of the formed $\mathrm{Ca}$ oxalate into $1.2 \mathrm{M} \mathrm{HCl}[26]$.

The $\mathrm{Ca}$ concentration in the $\mathrm{HCl}$ solution was measured by AAS and, if necessary, diluted in order to adjust to ca. $10 \mu \mathrm{g} / \mathrm{ml} \mathrm{Ca}$. Urine spot samples and 24 -h urine samples taken before and after isotope administration of the same subject were tested within one day, together with blank and standard of $10 \mu \mathrm{g} / \mathrm{ml} \mathrm{Ca}$. All values were adjusted for minor deviations from standard $\mathrm{Ca}$ solutions with accepted natural ratios. All samples were measured in duplicate.

\section{Statistics}

The differences among treatments for $\mathrm{Fe}$ or $\mathrm{Ca}$ metabolism were tested using an ANOVA with block structure [28]. In addition, all parameters were corrected for body weight, and Fe absorption and the other Fe isotope values were corrected for serum ferritin by analyses of covariance. The mean values of serum ferritin, SCFA, fecal $\mathrm{pH}$, enrichment of $\mathrm{Fe}$ and $\mathrm{Ca}$ isotopes and absorption of $\mathrm{Fe}$ and $\mathrm{Ca}$ over the 4 treatments for each subject were calculated. These overall means were used in correlation analyses [28]. Because some parameters (Fe and $\mathrm{Ca}$ absorption, the basal and enriched ${ }^{57} \mathrm{Fe} /{ }^{56} \mathrm{Fe}$ ratio, the enrichment of ${ }^{57} \mathrm{Fe}$, the basal ${ }^{44} \mathrm{Ca} /{ }^{43} \mathrm{Ca}$ ratio, hemoglobin, serum $\mathrm{Fe}, \mathrm{pH}$ ) did not have a symmetric distribution, natural logarithms of these data were used in the statistical tests.

\section{Results}

All subjects completed the study. During the FOS treatment the Ca absorption values of 2 subjects were excluded; one subject did not collect a basal urine spot, and another subject did not show an enrichment of the intravenously administered ${ }^{48} \mathrm{Ca}$ in his urine. 
Table 3 shows the mean Fe status values during each treatment. Using the criteria of Fairweather-Tait [3], none of the subjects were considered to be Fe-deficient. When corrected for body weight, TIBC was less when FOS was given than during the control treatment $(P<0.05)$. No other significant differences in Fe status were found among treatments.

Table 3 Fe status during the different treatments ${ }^{1}$

\begin{tabular}{lcccc}
\hline Fe status & Inulin FOS & GOS Control & & \\
\hline Hb (mmol/1) & $9.5 \pm 0.5$ & $9.5 \pm 0.9$ & $9.4 \pm 0.5$ & $9.5 \pm 0.5$ \\
& $(8.8-10.3)$ & $(8.5-11.7)$ & $(8.5-10.1)$ & $(8.6-10.2)$ \\
Ferritin $(\mu \mathrm{g} / 1)$ & $84 \pm 58$ & $86 \pm 53$ & $82 \pm 49$ & $84 \pm 48$ \\
& $(18-187)$ & $(23-185)$ & $(15-171)$ & $(18-174)$ \\
Tf-saturation $(\%)$ & $33 \pm 11$ & $32 \pm 5$ & $32 \pm 9$ & $31 \pm 5$ \\
& $(16-56)$ & $(26-42)$ & $(21-55)$ & $(21-40)$ \\
TIBC $(\mu$ mol/l) & $60 \pm 5$ & $58 \pm 5$ & $58 \pm 5$ & $60 \pm 6$ \\
& $(53-71)$ & $(46-67)^{2}$ & $(53-71)$ & $(50-69)$ \\
\hline
\end{tabular}

Values are mean $\pm S D$ (range), $\mathrm{n}=12 ;{ }^{2}$ Significantly different from the control treatment when corrected for body weigth, $\mathrm{P}<0.05$.

In blood taken on day 15 of the first treatment period $(n=12)$, the basal ratio of ${ }^{57} \mathrm{Fe} /{ }^{56} \mathrm{Fe}$ was $0.0237(0.6 \mathrm{CV} \%)$ and of ${ }^{58} \mathrm{Fe} /{ }^{56} \mathrm{Fe} 0.00304(1.5 \mathrm{CV} \%)$. The average enrichment value (mean $\pm S E M$ ) found in blood taken 2 weeks after each isotope administration was $2.82 \pm 0.42 \%$ for the ${ }^{57} \mathrm{Fe} /{ }^{56} \mathrm{Fe}$ ratio $(\mathrm{n}=48)$ and amounted to $10.57 \pm 0.45 \%$ for the ${ }^{58} \mathrm{Fe} /{ }^{56} \mathrm{Fe}$ ratio $(\mathrm{n}=24)$. About half $(48 \%)$ of the enrichment values of the ratio of ${ }^{57} \mathrm{Fe} /{ }^{56} \mathrm{Fe}$ were less than detection limit of $1.9 \%$ ( 3 times the SD of the basal ratio). This indicated a very low Fe absorption in these healthy young men. All enrichment values of the ${ }^{58} \mathrm{Fe} /{ }^{56} \mathrm{Fe}$ ratio were above the detection limit. Based on two values per subject instead of four the utilization of ${ }^{58} \mathrm{Fe}$ (mean $\pm S E M$ ), which indicates the amount of absorbed ${ }^{57} \mathrm{Fe}$ incorporated into erythrocytes, was 88.0 $\pm 1.7 \%$. 
Table 4 Percentage absorption of iron calculated from the enrichment of ${ }^{57} \mathrm{Fe} /{ }^{56} \mathrm{Fe}$ and ${ }^{58} \mathrm{Fe} /{ }^{56} \mathrm{Fe}$ in erythrocytes.

\begin{tabular}{crrrr}
\hline \multirow{2}{*}{ Subject } & \multicolumn{5}{c}{ Treatments } \\
\cline { 2 - 5 } & Inulin & FOS & GOS & Control \\
\hline 01 & 1.8 & 2.1 & 0.1 & 0.9 \\
02 & 2.0 & 4.7 & 0.1 & 4.4 \\
03 & 12.5 & 22.8 & 22.4 & 16.7 \\
04 & 3.7 & 3.0 & 4.8 & 2.2 \\
05 & 17.0 & 16.5 & 9.4 & 12.8 \\
06 & 1.1 & 5.1 & 1.8 & 6.8 \\
07 & 0.5 & 2.7 & 2.0 & 3.8 \\
08 & 1.4 & 0.3 & 4.2 & 2.0 \\
09 & 13.9 & 4.8 & 11.4 & 1.4 \\
10 & 4.4 & 1.8 & 1.2 & 8.4 \\
11 & 4.0 & 5.5 & 5.0 & 1.1 \\
12 & 3.2 & 4.4 & 1.0 & 1.2 \\
\hline mean & 5.5 & 6.1 & 5.3 & 5.1 \\
SEM & 1.6 & 1.9 & 1.9 & 1.5 \\
\hline
\end{tabular}

In urine taken before each isotope administration $(\mathrm{n}=47)$, the average basal ${ }^{44} \mathrm{Ca} /{ }^{43} \mathrm{Ca}$ ratio was $15.5(1.1 \mathrm{CV} \%)$ and of the ${ }^{48} \mathrm{Ca} /{ }^{43} \mathrm{Ca}$ ratio $1.45(2.5 \mathrm{CV} \%)$. The average enrichment value (mean $\pm \mathrm{SEM} ; \mathrm{n}=47$ ) found in urine collected over $24 \mathrm{~h}$ after each isotope administration was $4.1 \pm 0.2 \%$ for the ${ }^{44} \mathrm{Ca} /{ }^{43} \mathrm{Ca}$ ratio and $10.7 \pm$ $0.4 \%$ for the ${ }^{48} \mathrm{Ca} /{ }^{43} \mathrm{Ca}$-ratio. All enrichment values were above the detection limit.

As $\mathrm{Fe}$ and $\mathrm{Ca}$ absorption values were not symmetrically distributed, the natural logarithms of these values were used. No significant differences in Fe or Ca absorption were found among treatments after $\log$ transformation $(P=0.503$ and $P=0.933$, respectively). The residual standard deviations of $\ln$ (Fe absorption) and $\ln$ ( $\mathrm{Ca}$ absorption) were 0.97 and 0.32 , respectively. Fe absorption corrected for serum ferritin did not differ among treatments either $(P=0.490)$. Table 4 and 5 shows the individual $\mathrm{Ca}$ and $\mathrm{Fe}$ absorption values for each treatment. 
Table 5 Percentage absorption of calcium calculated from the enrichment of ${ }^{44} \mathrm{Ca} /{ }^{43} \mathrm{Ca}$ and ${ }^{48} \mathrm{Ca} /{ }^{43} \mathrm{Ca}$ in urine

\begin{tabular}{crrrr}
\hline \multirow{2}{*}{ Subject } & \multicolumn{5}{c}{ Treatments } \\
\cline { 2 - 5 } & Inulin & FOS & GOS & Control \\
\hline 01 & 29.1 & 25.3 & 26.0 & 68.3 \\
02 & 23.5 & 25.0 & 25.5 & 32.7 \\
03 & 36.8 & & 40.8 & 27.8 \\
04 & 26.0 & 24.2 & 18.8 & 39.1 \\
05 & 28.1 & 34.1 & 33.7 & 29.2 \\
06 & 18.7 & & 31.0 & 14.5 \\
07 & 34.8 & 37.9 & 33.3 & 30.3 \\
08 & 13.8 & 21.4 & 25.0 & 25.2 \\
09 & 38.6 & 24.7 & 19.6 & 16.0 \\
10 & 19.9 & 27.3 & 7.2 & 18.5 \\
11 & 18.9 & 16.9 & 21.7 & 18.5 \\
12 & 22.0 & 26.4 & 33.0 & 17.6 \\
\hline mean & 25.8 & 26.3 & 26.3 & 28.1 \\
SEM & 2.3 & 1.9 & 2.6 & 4.3 \\
\hline
\end{tabular}

Figure 1. shows the correlation between mean overall Fe absorption per subject over the 4 treatments and their mean overall serum ferritin level after log transformation $(r=-0.868, P<0.001)$.

No significant differences in fecal pH and most of the SCFA were found among treatments, except for the concentration of acetic acid which increased when the diet was supplemented with $15 \mathrm{~g}$ of GOS or inulin $(\mathrm{P}<0.05)$. In an attempt to identify determinants of $\mathrm{Fe}$ or $\mathrm{Ca}$ metabolism, correlations with fecal pH and SCFA were calculated. All failed to reach statistical significance $(P>0.10)$ except for the correlation between ${ }^{57} \mathrm{Fe}$ enrichment and the concentration of butyric acid $(r=0.588$, $\mathrm{P}<0.05)$. 
Figure 1 Correlation between mean overall iron absorption per subject over the 4 treatments and their mean overall serum ferritin after $\log$ transformation $(\mathrm{n}=12, \mathrm{r}=-0.87, \mathrm{P}<0.001)$.

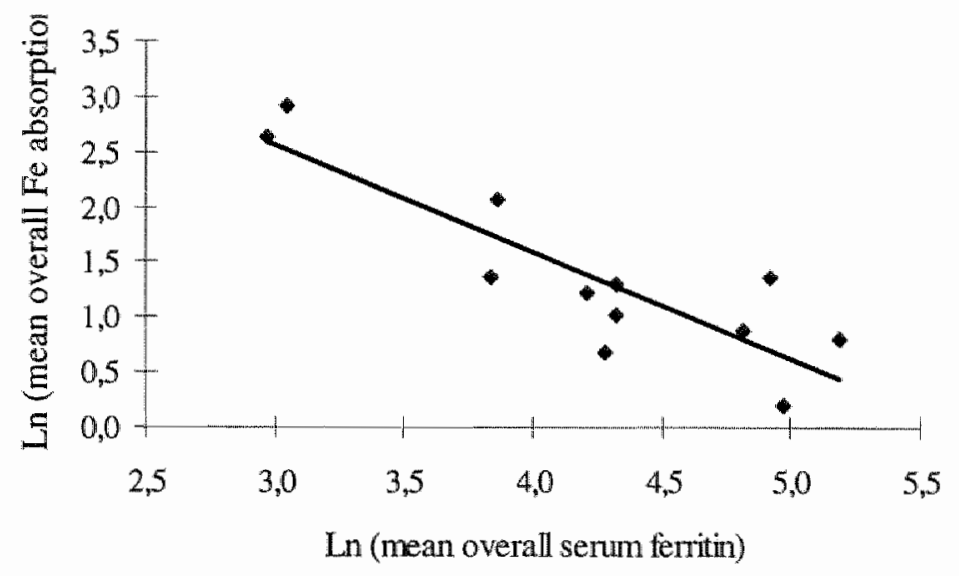

\section{Discussion}

The method of Barrett et al [15] was chosen to measure Fe absorption, which so far has been executed only in women, who generally have a smaller blood volume [29] and absorb more Fe than men [30]. Therefore, in men a higher dose of isotopes is needed to achieve a significant enrichment in the isotope ratio of erythrocytes sampled within 15 days after dose administration. The required dose of ${ }^{57} \mathrm{Fe}$ and ${ }^{58} \mathrm{Fe}$ was calculated assuming an absorption of $6 \%$ and an incorporation of the absorbed Fe into erythrocytes of $80 \%$. The limits of detection were set at three times the SD above basal ratio [31], which corresponds to an enrichment of $1.9 \%$ for ${ }^{57} \mathrm{Fe} /{ }^{56} \mathrm{Fe}$ and of $4.4 \%$ for ${ }^{58} \mathrm{Fe} /{ }^{56} \mathrm{Fe}$ in the present study. To avoid excessive and non-physiological $\mathrm{Fe}$ intake, the oral dose of ${ }^{57} \mathrm{Fe}$ was spread over 1 week and the Fe content of the basal diet was somewhat adapted. Extra vitamin $\mathrm{C}$ was added to the orange juice with or without NDO to increase Fe absorption to at least $6 \%$. Despite the addition of vitamin $\mathrm{C}$, average $\mathrm{Fe}$ absorption (mean $\pm \mathrm{SEM}$ ) was $5.5 \pm 0.8 \%$. About half of the enrichments of ${ }^{57} \mathrm{Fe} /{ }^{56} \mathrm{Fe}$ were below the detection limit. This indicates a very low $\mathrm{Fe}$ absorption in these healthy young men. The low absorption is in accordance with the 
high $\mathrm{Fe}$ status and the high negative correlation between serum ferritin and $\mathrm{Fe}$ absorption.

In men with saturated Fe stores we should consider not only the absorption function of the intestine but also the barrier function of the intestine, since Fe overload can have negative effects on health [32]. Total Fe losses in males amount to about 0.9-1 $\mathrm{mg}$ per day [33]. To compensate for these daily losses, in the present study the average Fe absorption should have been 5.4 to $6.5 \%$, which was indeed the case.

In other studies [34-36] with male subjects mean $\mathrm{Fe}$ absorption percentages varied between 2.5 and $5 \%$, when the oral isotope was given without vitamin $\mathrm{C}$ added. It is possible that the effect of vitamin $\mathrm{C}$ on Fe absorption is less than has been predicted from tests with single meals, as proposed by Hunt et al [37]. Besides, also Cook et al [38], using the multiple meal technique, found a geometric mean non-haem $\mathrm{Fe}$ absorption in a diet designed to be highly bioavailable of only $6.6 \%$ in both men and wormen. This is not so much different from the $3.1 \%$ (geometric mean) found in the present study, in which the high Ca content in breakfast in the present study could have led to a reduction of $\mathrm{Fe}$ absorption [39]. Therefore, the Fe absorption values found in the present study correspond to values reported in literature.

The measurement of fractional absorption of $\mathrm{Ca}$ from a 24-h urine collection after oral and intravenous administration of two different isotopes of $\mathrm{Ca}$ has been shown to be an accurate and reliable technique [40, 41]. Fractional $\mathrm{Ca}$ absorption has been found to be inversely correlated with the logarithm of the size of the ingested $\mathrm{Ca}$ load [42]. Therefore, in the present study Ca absorption (mean \pm SEM) from a breakfast containing $513 \mathrm{mg}$ of $\mathrm{Ca}$ was $26.6 \pm 1.4 \%$ and hence lower than values found by Fairweather-Tait et al [43], who added $30 \mathrm{mg}$ of ${ }^{44} \mathrm{Ca}$ to watercress soup, skimmed or Ca-enriched milk, which contained ca. $150 \mathrm{mg} \mathrm{Ca}(27.4 \pm 1.9 \%, 45.5 \pm 1.9 \%$ or 35.7 $\pm 4.7 \%$, respectively). In fasting men $\mathrm{Ca}$ absorption from orange juice with $0.5 \mathrm{mg} / \mathrm{kg}$ ${ }^{44} \mathrm{Ca}$ was $51.9 \pm 3.8 \%$ [44]. Therefore, the lower $\mathrm{Ca}$ absorption found in our study is attributable to the fact that the oral dose was given during breakfast containing a relatively large amount of $\mathrm{Ca}$.

Like other fermentable, indigestible carbohydrates, NDO do not seem to inhibit $\mathrm{Fe}$ absorption in humans. Contrary to our results, a positive effect of FOS on Fe absorp- 
tion has been found in rats [7, 9]. In the study of Ohta et al [7], 8-week old Fe-deficient rats were used, while in our study subjects with normal Fe stores were selected. With increasing Fe stores, true differences in bioavailability are rare and more difficult to demonstrate [45]. However, an increased Fe absorption has also been observed in growing rats with normal Fe stores which were given $10 \%$ of FOS or inulin for 24 days [9]. According to Galibois et al [46], 5\% fiber in a rat diet corresponds to roughly $20 \mathrm{~g}$ fiber per day in a typical western diet and $10 \%$ fiber to about $40 \mathrm{~g} /$ day. If this conversion also holds for NDO, Delzenne et al [9] have been given twice the amount of NDO we gave.

$\mathrm{Ca}$ absorption takes place by two routes. The non-saturable paracellular route of $\mathrm{Ca}$ occurs throughout the small intestine and is thought to be driven by passive diffusion. The saturable active transcellular transport is the major absorptive pathway in the proximal intestine [47]. The large intestine may represent a major site of $\mathrm{Ca}$ absorption when acidic fermentations take place [48]. Rat experiments have shown that fermentable oligosaccharides facilitate colorectal [8] and cecal absorption of $\mathrm{Ca}$ $[4,6]$. A high rate of passive $\mathrm{Ca}$ absorption in the large intestine could trigger a feedback mechanism involving inhibition of duodenal active absorption as a consequence of a change in endocrine factors $[49,50]$. In our study no effect of NDO on Ca absorption was found, but we cannot exclude two possibilities. First, the NDO were given for 3 weeks and the activation of a feedback mechanism could already have occurred. Second, if the large intestine is the major place where NDO enhance Ca absorption, a 24-h period of collection of urine may be too short to detect an effect. Moreover, an isotope dilution effect may have been present in the colon. Although the subjects ate their last food about $12 \mathrm{~h}$ before the absorption test, probably the colon still contains $\mathrm{Ca}$ from earlier meals. Due to this $\mathrm{Ca}$ the $\mathrm{Ca}$ isotope might have been diluted, decreasing the sensitivity to detect colonic absorption.

It is concluded that $15 \mathrm{~g}$ of inulin, FOS, or GOS per day does not have a negative effect on $\mathrm{Fe}$ and $\mathrm{Ca}$ absorption in young healthy men. We might have missed a positive effect of NDO on the colonic part of $\mathrm{Ca}$ absorption by using the dual stable isotope technique in combination with a 24-h urine collection. 


\section{Acknowledgment}

Sources of support: European Union and ORAFTI s.a., Tienen, Belgium.

\section{References}

1 Roberfroid M. Dietary fiber, inulin, and oligofructose: a review comparing their physiological effects. Crit Rev Food Sci Nutr 1993;33:103-148.

2 Bunker VW. The role of nutrition in osteoporosis. Br J Biomed Sci 1994;51:228-240.

3 Fairweather-Tait S. Iron. Int J Vitam Nutr Res 1993;63:296-301.

4 Demigné C, Levrat MA \& Rémésy C. Effects of feeding fermentable carbohydrates on the cecal concentrations of minerals and their fluxes between the cecum and blood plasma in the rat. $J$ Nutr 1989;119:1625-1630.

5 Rémésy C, Levrat MA, Gamet L \& Demigné C. Cecal fermentations in rats fed oligosaccharides (inulin) are modulated by dietary calcium level. Am J Physiol 1993;264:G855-G862.

6 Ohta A, Ohtuki $M$, Takizawa $T$, Inaba $H$, Adachi $T$ \& Kimura $S$. Effects of fructo-oligosaccharides on the absorption of magnesium and calcium by cecectomized rats. Int $J$ Vitam Nutr Res 1994;64:316-323.

7 Ohta A, Ohtsuki $M$, Baba $S$, Takizawa $T$, Adachi $T$ \& Kimura $S$. Effects of fructo-oligosaccharides on the absorption of iron, calcium and magnesium in iron-deficient anemic rats. J Nutr Sci Vitaminol 1995;41:281-291.

8 Ohta A, Ohtsuki M. Baba S, Adachi T, Sakata T \& Sakaguchi E. Calcium and magnesium absorption from the colon and rectum are increased in rats fed fructo-oligosaccharides. $J$ Nutr $1995 ; 125: 2417-2424$.

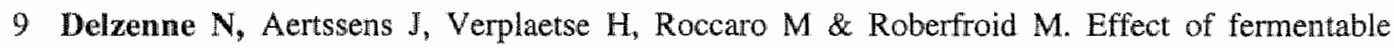
fructo-oligosaccharides on mineral, nitrogen and energy digestive balance in the rat. Life Sci 1995:57:1579-1587.

10 Reiser S. Metabolic effects of dietary pectins related to human health. Food technol 1987:41:91-99.

11 Behall KM. Effect of soluble fibers on plasma lipids, glucose tolerance and mineral balance. In: New developments in dietary fiber. Furda I, Brine CJ, eds. New York: Plenum Press, 1990:7-16.

12 Behall KM, Scholfield DJ, Lee K, Powell AS \& Moser PB. Mineral balance in adult men: effect of four refined fibers. Am J Clin Nutr 1987;46:307-314.

13 Briet F, Achour L, Flourie B, Beaugerie L, Pellier P, Franchisseur C, Bornet F \& Rambaud JC. Symptomatic response to varying levels of fructo-oligosaccharides consumed occasionally or regularly. Eur J Clin Nutr 1995;49:501-507.

14 Nutritional Education Board. Result national Dutch food consumption surveys, 1992. Meppel: Ten Brink. 1993.

15 Barrett JF, Whittaker $\mathrm{PG}$, Williams JG \& Lind T. Absorption of non-haem iron in normal women measured by the incorporation of two stable isotopes into erythrocytes. Clin Sci 1992;83:213-219.

16 Eastell R, Vieira NE, Yergey AL \& Riggs BL. One-day test using stable isotopes to measure true fractional calcium absorption. J Bone Miner Res 1989;4:463-468. 
17 De Bièvre $\mathbf{P}$ \& Taylor PDP. Table of isotopic compositions of the elements. Int J Mass Spectrom Ion Processes 1993;123:149-166.

18 Kastenmayer P, Davidsson L, Galan P, Cherouvrier F, Hercberg S \& Hurrell RF. A double stable isotope technique for measuring iron absorption in infants. Br J Nutr 1994;71:411-424.

19 Schormüller J. Handbuch der lebensmittelchemie. 4th edit. Berlin: Springer Verslag, 1969.

20 Van de Kamer JH. The determination of starch using pancreas amylase. Chemisch Weekblad 1941;38:286-288.

21 Prosky L, Asp NG, Schweizer TF, DeVries JW \& Furda I. Determination of insoluble, soluble, and total dietary fiber in foods and food products: interlaboratory study.J Assoc Off Anal Chem $1988 ; 71: 1017-1023$.

22 Bio-Rad. HPLC application, organic acid application. In: Bio-Rad Catalogus R. 1992:123-129.

23 Nevo Foundation Editorial Board. Food composition table 1993-1994. The Hague: Krips Repro, 1994.

24 Bothwell TH, Charlton RW, Cook JD \& Finch CA. Iron metabolism in man. London: Blackwell Scientific Publications, 1979.

25 Van Dokkum W, De La Gueronmiere V, Schaafsma G, Bouley C, Luten J \& Latge C. Bioavailability of calcium of fresh cheeses, enteral food and mineral water. A study with stable calcium isotopes in young adult women. Br J Nutr 1996;75:893-903.

26 Luten JB, Muijs T \& Van Dokkum W. The determination of stable isotope ratio of zinc, copper, iron in faeces and calcium in urine by ICP-MS. In: Bioavailability '93. Nutritional, chemical and food processing implications of nutrient availability. Schlemmer U, ed. Karlsruhe: Bundesforschungsanstalt für Ernährung, 1993:161-168.

27 Gray AL \& Williams JG. System optimisation of the effect on polyatomic, oxide and double charged ion response of a commercial inductively coupled plasma mass spectrometry instrument. $J$ Anal At Spectrom 1987;2:599-606.

28 Genstat 5 Committee. Genstat five release three reference manual. New York: Oxford University Press, 1994.

29 Geigy Scientific Tables. 8th edit. Basle: Ciba-Geigy, 1981.

30 Cook JD, Dassenko S \& Skikne BS. Serum transferrin receptor as an index of iron absorption. Br I Haematol 1990;75:603-609.

31 Miller JC \& Miller JN. Errors in instrumental analysis;regression and correlation. In: Statistics for analytical chemistry. 2nd edit. Miller JC, Miller JN, eds. West Sussex: Ellis Horwood Limited, 1988:101-135.

32 Hallberg L. Results of surveys to assess iron status in Europe. Nutr Rev 1995;53:314-322.

33 Bothwell TH. Overview and mechanisms of iron regulation. Nutr Rev 1995;53:237-245.

34 Gleerup A, Rossander-Hulten L \& Hallberg L. Duration of the inhibitory effect of calcium on non-haem iron absorption in man. Eur J Clin Nutr 1993;47:875-879.

35 Skikne BS \& Cook JD. Effect of enhanced erythropoiesis on iron absorption. J Lab Clin Med 1992;120:746-751.

36 Galan P, Cherouvrier F, Preziosi P \& Hercberg S. Effects of the increasing consumption of dairy products upon iron absorption. Eur J Clin Nutr 1991;45:553-559.

37 Hunt JR, Gallagher SK \& Johnson LK. Effect of ascorbic acid on apparent iron absorption by women with low iron stores. Am J Clin Nutr 1994;59:1381-1385. 
38 Cook JD, Dassenko SA \& Lynch SR. Assessment of the role of nonheme-iron availability in iron balance. Am J Clin Nutr 1991;54:717-722.

39 Hallberg L, Brune M, Erlandsson M, Sandberg AS \& Rossander-Hulten L. Calcium: effect of different amounts on nonheme- and heme-iron absorption in humans. Am $J$ Clin Nutr $1991 ; 53: 112-119$.

40 Yergey AL, Abrams SA, Vieira NE, Aldroubi A, Marini J \& Sidbury JB. Determination of fractional absorption of dietary calcium in humans. $J$ Nutr $1994 ; 124: 674682$.

41 Griessen $M$, Jung $A$, Cochet B, Bartholdi $P$, Gaspoz JM, Infante $F_{n}$ Donath $A$, Loizeau $E$ \& Courvoisier B. A simple method for measurement of intestinal calcium absorption in humans by double-isotope technique. I Lab Clin Med 1985;105:641-646.

42 Heaney RP, Weaver CM \& Fitzsimmons ML. Influence of calcium load on absorption fraction. J Bone Miner Res 1990;5:1135-1138.

43 Fairweather-Tait S.J, Johnson A, Eagles J, Ganatra S, Kennedy H \& Gurr MI. Studies on calcium absorption from milk using a double-label stable isotope technique. Br $J$ Nur $1989 ; 62: 379-388$.

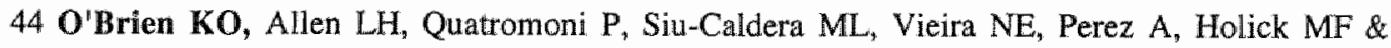
Yergey AL. High fiber diets slow bone turnover in young men but have no effect on efficiency of intestinal calcium absorption. $J$ Nutr 1993; 123:2122-2128.

45 Hultén L, Gramatkowski E, Gleerup A \& Hallberg L. Iron absorption from the whole diet. Relation to meal composition, iron requirements and iron stores. Eur $J$ Clin Nutr 1995;49:794-808.

46 Galibois I, Desrosiers T, Guevin N, Lavigne C \& Jacques H. Effects of dietary fibre mixtures on glucose and lipid metabolism and on mineral absorption in the rat. Ann Nutr Metab 1994;38:203-211.

47 Klugman VA \& Favus MJ. Intestinal absorption of calcium, magnesium and phosphorus. In: Kidney stones: medical and surgical management. Coe FL, Favus MJ, Pak CYC, Parks JH, Preminger GM, eds. Philadelphia: Lippincott-Raven Publishers, 1996:201-221.

48 Vounes $\boldsymbol{H}$, Demigné $\mathrm{C}$ \&émésy $\mathrm{C}$. Acidic fermentation in the caecum increases absorption of calcium and magnesium in the large intestine of the rat. Br J Nutr 1996;75:301-314.

49 Nellans $\mathrm{HN}$ Goldsmith RS. Transepithelial calcium transport by rat cecum: high-efficiency absorptive site. Am J Physiol 1981;240:G424-G431.

50 Bronner F, Pansu D \& Stein WD. An analysis of intestinal calcium transport across the rat intestine. Am J Physiol 1986;250:G561-G569. 


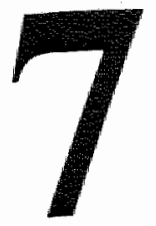

\section{Fructo-oligosaccharides \\ absorption in adolescents}

Ellen GHM van den Heuvel, Theo Muijs, Wim van Dokkum and Gertjan Schaafsma Submitted

\section{Abstract}

In rats non-digestible oligosaccharides stimulate calcium absorption. Recently this effect was also found in human subjects. The aim of the present study was to investigate whether $15 \mathrm{~g}$ of fructo-oligosaccharides per day stimulate calcium absorption in boys.

Twelve healthy boys aged between 14 and 16 y received, for $9 \mathrm{~d}, 15 \mathrm{~g}$ of fructooligosaccharides or sucrose (control treatment) spread over the day. The treatments were given according to a randomized, double-blind, cross-over design, separated by a $19-\mathrm{d}$ wash-out period. On the 8 th day of each treatment period ${ }^{44} \mathrm{Ca}$ was given orally with a standard breakfast containing ca. $200 \mathrm{mg}$ of calcium. Within hall an hour after the oral administration, the ${ }^{48} \mathrm{Ca}$ isotope was administered intravenously. From the enrichment of the ${ }^{44} \mathrm{Ca} /{ }^{43} \mathrm{Ca}$ and ${ }^{48} \mathrm{Ca} /{ }^{43} \mathrm{Ca}$ ratios in 36 -h urine, measured by inductively coupled plasma mass spectrometry, fractional calcium absorption was computed. Colonic absorption was included by collecting urine over $36 \mathrm{~h}$ instead of $24 \mathrm{~h}$ after isotope administration.

An increase in fractional calcium absorption (\%) was found upon consumption of fructo-oligosaccharides (mean $\pm \mathrm{SD}: 60.1 \pm 17.2 \mathrm{vs} .47 .8 \pm 16.4 ; \mathrm{P}<0.05$, one-sided). In conclusion, $15 \mathrm{~g}$ of fructo-oligosaccharides per day stimulates calcium absorption in adolescent boys. The results are discussed in relation to the methodology used. 


\section{Introduction}

Fructo-oligosaccharides (FOS) are a mixture of oligosaccharides composed of fructose units linked together by $\beta(2-1)$ linkages. Part of these molecules are terminated by a glucose unit. The total number of fructose or glucose units of FOS range mainly between 2 and 8 .

FOS resist hydrolysis by human alimentary enzymes [1]. Using mixed faecal bacteria, it has been demonstrated that FOS are fermented by colonic microbiota and induce a decrease in $\mathrm{pH}$ of the human culture medium [2]. Due to this caeco-colonic fermentation, large amounts of short-chain fatty acids (SCFA) are produced, which may cause a trophic effect on intestinal epithelium as well as the triglycerides- and cholesterol-lowering effects of these non-digestible oligosaccharides (NDO) [1].

Besides, like other NDO, FOS have been shown to improve mineral absorption in rats [3-5]. In an earlier study we investigated the effects of NDO on true calcium (Ca) and iron absorption in adult men (mean age 23 years) using stable isotope techniques. No effects were found. Using the chemical balance technique, Coudray et al [6] did find a positive effect of the non-digestible oligosaccharide inulin on apparent $\mathrm{Ca}$ absorption in adult men.

Ellegård et al [7] have shown that, in ileostomy subjects, neither inulin nor FOS influence the absorption of $\mathrm{Ca}$ in the small intestine. Therefore, the positive effect on $\mathrm{Ca}$ balance found by Coudray et al [6] is likely to originate predominantly in the colon. This agrees with the view of Younes et all [8] that the large intestine may represent a major site of $\mathrm{Ca}$ and $\mathrm{Mg}$ absorption when acidic fermentation takes place. Barger-Lux et al [9] have demonstrated that the complete Ca absorption does not reach completion until about $26 \mathrm{~h}$ after the oral dose. It is possible that our previous study (Chapter 6) [10] did not include completely the colonic component of $\mathrm{Ca}$ absorption, because the dual stable isotope technique we used did not include the amount of $\mathrm{Ca}$ absorbed after $24 \mathrm{~h}$ of isotope administration.

Most animal experiments were carried out in young growing animals. Although Coudray et al [6] found a positive effect on $\mathrm{Ca}$ absorption in subjects with a mean age of $22 \mathrm{y}$, the large dose of inulin $(40 \mathrm{~g} / \mathrm{d})$ may have mediated a large and thus more detectable effect. The stimulating effect of a more plausible dose of FOS on mineral 
absorption could be more pronounced in younger volunteers, whose Ca requirement is larger.

The aim of the present study was to investigate whether $15 \mathrm{~g}$ of FOS stimulates true absorption of $\mathrm{Ca}$ in boys. Absorption was measured using the dual stable isotope technique. The colonic part of $\mathrm{Ca}$ absorption was included by extending the collection of urine over $36 \mathrm{~h}$ instead of $24 \mathrm{~h}$ after isotope administration.

\section{Subjects and methods}

Subjects

Subjects in this study were recruited through an advertisement in a local newspaper. Twelve healthy boys were selected for the study. At the start of the study their age ranged between 14 and 16 y (mean 15.3) and their body mass index between 16.0 and $20.7 \mathrm{~kg} / \mathrm{m}^{2}$ (mean 18.4). Normal health was assessed at pre-study screening, which included a medical history, physical examination, measurement of blood pressure and heart rate and routine clinical laboratory tests. The study protocol was approved by the TNO external Medical Ethics Committee and all subjects and their parents signed informed consent forms.

\section{Preparation of stable isotope solutions}

The dual stable isotope technique involves the administration of two stable isotopes, one orally and one intravenously. Taking the amount administered and the natural abundances of these stable isotopes into account, true fractional Ca absorption can be calculated from the enrichment of both stable isotopes in a urine sample [11].

The isotopic labels were obtained from NEDRAY (Bunschoten, Netherlands) in the form of calcium carbonate. The abundances of the different isotopic labels according to inductively coupled plasma mass spectrometry (ICP-MS) analysis were: Ca enriched in ${ }^{44} \mathrm{Ca}, 3.39 \%{ }^{40} \mathrm{Ca}, 0.06 \%{ }^{42} \mathrm{Ca}, 0.03 \%{ }^{43} \mathrm{Ca}, 96.5 \%{ }^{44} \mathrm{Ca},<0.01 \%{ }^{46} \mathrm{Ca}$, $0.02 \%{ }^{48} \mathrm{Ca}$, and $\mathrm{Ca}$ enriched in ${ }^{48} \mathrm{Ca}, 8.96 \%{ }^{40} \mathrm{Ca}, 0.09 \%{ }^{42} \mathrm{Ca}, 0.02 \%{ }^{43} \mathrm{Ca}, 0.24 \%$ ${ }^{44} \mathrm{Ca},<0.01 \%{ }^{46} \mathrm{Ca}, 90.69 \%{ }^{48} \mathrm{Ca}$. One subject was given $\mathrm{Ca}$ enriched in ${ }^{44} \mathrm{Ca}$, left from an earlier experiment, which had the following enrichment: $2.80 \%{ }^{40} \mathrm{Ca}, 0.05 \%{ }^{42} \mathrm{Ca}$, 
$0.02 \%{ }^{43} \mathrm{Ca}, 97.1 \%{ }^{44} \mathrm{Ca},<0.002 \%{ }^{46} \mathrm{Ca}, 0.03 \%{ }^{48} \mathrm{Ca}$

The ${ }^{44} \mathrm{Ca}$ carbonate was converted into chloride salt, diluted with de-ionized water, followed by $\mathrm{pH}$ adjustment to 5 . A similar procedure was followed for ${ }^{48} \mathrm{Ca}$ carbonate, except that saline was used instead of de-ionized water [12]. After filtration the solution was distributed over $10 \mathrm{ml}$ injection bottles and sterilized for $25 \mathrm{~min}$.

Table 1 The composition of Raftilose $\mathrm{BP} 95$

Oligo-fructose (\% on d.m.")

Glucose/fructose/sucrose (\% on d.m.)

Dry matter (\%)

Ash ( $\%$ on d.m.)

DP range
95

5

$\geq 95$

$<0.2$

$2-8$

d.m. = dry matter

Study design and execution of the study

The subjects were asked to keep their habitual food intake during the study as constant as possible, but to restrict consumption of fibre-rich and oligosaccharidecontaining food products.

During the two 9-d treatment periods subjects drank 3 times (at breakfast, lunch and dinner) $100 \mathrm{ml}$ of orange juice containing $5 \mathrm{~g}$ of FOS (Raftilose@P95, ORAFTI, Tienen, Belgium) or the reference substance. As the pure oligosaccharide content of Raftilose@P95 was not 100\% (see Table 1), the weight of FOS was adjusted for a constant intake of $5 \mathrm{~g}$ of pure FOS. The reference substance consisted of finepowdered sucrose. Both drinks with the study substance had the same sweetness due to addition of aspartame. The treatments were given to the subjects according to a randomized cross-over design. This strictly controlled study was executed in a "double-blind" mode.

During the first $7 \mathrm{~d}$ of each treatment period the subjects consumed the study substance supplied at home. On the last two days of each treatment period the subjects were housed in the metabolic unit of the Institute and the Ca absorption tests were carried out. During their stay at TNO the diet was standardized and contained $1267 \mathrm{mg}$ of $\mathrm{Ca}$ and $12 \mathrm{MJ}$ of energy of which $12 \%$ derived from protein, $59 \%$ from 
carbohydrates and $29 \%$ from fat, as estimated from the Dutch Food Composition Table [13].

For the $\mathrm{Ca}$ absorption test, the orange juice with the study substance was extrinsically labelled with ${ }^{44} \mathrm{Ca}$. On the 8 th day of each treatment period, after a 12 -h overnight fast, this orange juice was given with a standard breakfast (with ca. $200 \mathrm{mg}$ of carrier Ca). Until $4 \mathrm{~h}$ after oral administration of ${ }^{44} \mathrm{Ca}$, no food or drinks were allowed except for water. The ${ }^{48} \mathrm{Ca}$ isotope was administered intravenously within $30 \mathrm{~min}$ after the oral administration of ${ }^{44} \mathrm{Ca}$. Before and after the bolus injection blood pressure and heart rate were recorded for safety reasons.

The exact quantity of isotopes given by each route, as calculated by weighing the bottles or syringes before and after administration, amounted to 14.0 (range 13.0 . 15.5) $\mathrm{mg}$ of ${ }^{44} \mathrm{Ca}$ and 1.15 (range $1.09-1.16$ ) $\mathrm{mg}$ of ${ }^{48} \mathrm{Ca}$. The ${ }^{44} \mathrm{Ca} /{ }^{43} \mathrm{Ca}$ and ${ }^{48} \mathrm{Ca} /{ }^{143} \mathrm{Ca}$ ratios in urine collected before dose administration and over the $36 \mathrm{~h}$ after dose administration were used to compute fractional $\mathrm{Ca}$ absorption according to the formula reported by Van Dokkum et al [11].

\section{Stable isotope analysis}

The $\mathrm{Ca}$ isotope ratios ${ }^{44} \mathrm{Ca} /{ }^{43} \mathrm{Ca}$ and ${ }^{48} \mathrm{Ca} /{ }^{43} \mathrm{Ca}$ in urine were measured by ICP-MS (Perkin Elmer Sciex, Elan 500) after protein precipitation with $3.5 \%$ trichloroacetic acid, precipitation of $\mathrm{Ca}$ with saturated ammonium oxalate and dissolution of the $\mathrm{Ca}$ oxalate formed into $1.2 \mathrm{M} \mathrm{HCl}$ [14]. The Ca concentration in the $\mathrm{HCl}$ solution was measured by atomic absorption spectrometry (AAS) and, if necessary, adjusted via dilution to ca. $10 \mu \mathrm{g} / \mathrm{ml} \mathrm{Ca}$. The prepared urine samples taken during each treatment, before and after isotope administration for the same subject were tested within one day, together with standard solutions of $10 \mu \mathrm{g} / \mathrm{ml} \mathrm{Ca}$ and blank solutions. All values were adjusted for minor deviations from standard $\mathrm{Ca}$ solutions with accepted natural ratios. All samples were measured in duplicate.

\section{Statistics}

Statistically, the null hypothesis was that there is no positive effect of FOS consumption on Ca absorption. Because the animal experiments and the human study 
of Coudray et al [6] indicated a positive effect of NDO on Ca absorption and our first human study (see Chapter 6) did not reveal a negative effect of FOS on mineral absorption, the alternative hypothesis was a positive effect of $15 \mathrm{~g}$ FOS per day on $\mathrm{Ca}$ absorption. The null hypothesis was to be rejected at the 0.05 level of probability (one-sided).

As one sample was lost, the differences in Ca absorption between treatments were evaluated by the procedure of General Linear Models for an unbalanced ANOVA [15]. ANOVA was used to be able to include the advantages of a cross-over design.

\section{Results}

All subjects completed the study. However, the 36-h urine sample of subject 12 collected during the treatment with FOS was lost. Compliance as checked by returned test substances and questionnaires was good. Only on Day 6 of the first treatment period two subjects forgot to drink their orange juice with study substance at dinner time.

All samples were measured in duplicate. Within-duplicate variation (coefficient of variation) was $0.30 \%$ for the ${ }^{44} \mathrm{Ca} /{ }^{49} \mathrm{Ca}$-ratio and was $0.82 \%$ for the ${ }^{48} \mathrm{Ca} /{ }^{43} \mathrm{Ca}$ ratio.

Due to a small amount of $\mathrm{Ca}$ in the basal urine sample, it was not possible to measure 3 to 4 basal urine samples. In these cases, the mean basal ratio per treatment period was taken. The average basal ${ }^{44} \mathrm{Ca}^{43} \mathrm{Ca}$ ratio $(\mathrm{n}=20)$ was $15.46(\mathrm{CV} 0.22 \%)$ and the ${ }^{48} \mathrm{Ca} /{ }^{43} \mathrm{Ca}$ ratio $(\mathrm{n}=19)$ was $1.407(\mathrm{CV} 1.70 \%)$. The average enrichment value $(\mathrm{n}=$ 23) was 4.8 (range $2.9-8.2$ ) \% for the urinary ${ }^{44} \mathrm{Ca} /{ }^{43} \mathrm{Ca}$ ratio and 8.8 (range 5.0$12.5) \%$ for the urinary ${ }^{48} \mathrm{Ca} /{ }^{43} \mathrm{Ca}$ ratio.

Mean Ca absorption ( $\pm \mathrm{SEM} ; \mathrm{n}=23$ ) was $53.7 \pm 3.7 \%$. Table 2 shows the mean basal and enriched ${ }^{44} \mathrm{Ca} /{ }^{43} \mathrm{Ca}$ and ${ }^{48} \mathrm{Ca} /{ }^{43} \mathrm{Ca}$ ratios and the mean enrichment percentages of these ratios per treatment. Figure 1 shows the increase of $\mathrm{Ca}$ absorption due to FOSconsumption ( $\mathrm{P}<0.05$, one-sided). 
Table 2 The ${ }^{44} \mathrm{Ca} /{ }^{43} \mathrm{Ca}$ and ${ }^{48} \mathrm{Ca} /{ }^{43} \mathrm{Ca}$ ratios and percentages enrichment per treatment $($ mean \pm SD)

$$
\begin{array}{cc}
\text { Reference substance } & \text { OF } \\
\mathrm{n}=12 & \mathrm{n}=11
\end{array}
$$

${ }^{44} \mathrm{Ca}{ }^{43} \mathrm{Ca}$ ratio

- Basal ${ }^{1}$

- Enriched

$$
\begin{aligned}
& 15.47 \pm 0.03 \\
& 16.13 \pm 0.18
\end{aligned}
$$$$
15.45 \pm 0.04
$$$$
16.28 \pm 0.18^{2}
$$

${ }^{416} \mathrm{Ca} / 3 \mathrm{Ca}$ ratio

- Basal ${ }^{1}$

- Enriched

$$
\begin{aligned}
& 1.40 \pm 0.02 \\
& 1.53 \pm 0.03
\end{aligned}
$$$$
1.41 \pm 0.03
$$$$
1.54 \pm 0.04
$$

Enrichment $(\%)$

- ${ }^{44} \mathrm{Ca}^{43} \mathrm{Ca}$ ratio

$$
4.3 \pm 1.2
$$$$
5.4 \pm 1.1^{3}
$$

- ${ }^{48} \mathrm{Ca}{ }^{43} \mathrm{Ca}$ ratio

$8.9 \pm 1.8$

$8.8 \pm 2.1$

During treatment with reference or OF $\mathrm{n}=9$ or $\mathrm{n}=10$, respectively. See text for explanation; ${ }^{2} \mathrm{P}=0.007$ compared to reference substance (ane-sided); ${ }^{3} \mathrm{P}=0.002$ compared to reference substance (one-sided).

No relation was found between $\mathrm{Ca}$ absorption and total amount of Ca excreted in 36 $\mathrm{h}$ urine. The total amount of $\mathrm{Ca}$ in the 36 -h urine was $126 \pm 87 \mathrm{mg}$ and $160 \pm 101 \mathrm{mg}$ for the reference and the FOS condition, respectively $(\mathrm{P}=0.06$, one-sided $)$. Also, no relation was found between the difference in $\mathrm{Ca}$ excretion and the difference in $\mathrm{Ca}$ absorption.

\section{Discussion}

The influence of FOS on true fractional $\mathrm{Ca}$ absorption was measured using the dual stable isotope technique. In contrast, in the human study of Coudray et al [6] and in rat experiments $[3,4]$ the effect of NDO on apparent Ca absorption was measured by using the chemical balance technique. The advantage of the chemical balance technique is that the complete $\mathrm{Ca}$ absorption is measured, including the colonic part. The disadvantage however, is that no distinction can be made between the unabsorbed and endogenously secreted mineral. In one rat experiment the faecal 
monitoring technique was applied [5]. Next to the two critical drawbacks of this labourious method, i.e. incomplete stool collection and sample in-homogeneity, the main reason for applying the dual stable isotope technique in the present study was to be able to compare the results with our earlier human study (see Chapter 6).

Figure 1 Change in $\mathrm{Ca}$ absorption $\%$ due to $15 \mathrm{~g}$ of fructowoligosaccharides per day (mean \pm SEM).

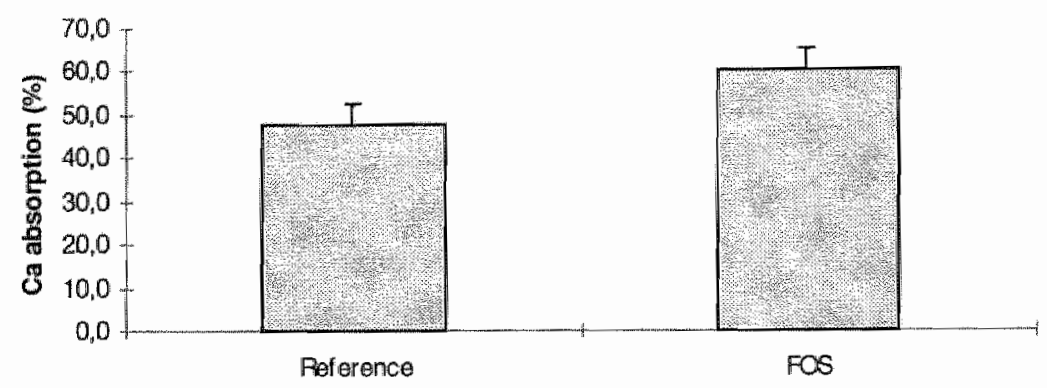

Determining the ratio of isotopes excreted in complete urine collections is one of the oldest approaches developed for the measurement of true fractional $\mathrm{Ca}$ absorption, and has been used in our work with the stable isotope administered orally in a single meal $[10,11]$. Using complete urine collections over a period of time instead of using a single spot urine or blood sample, gives better approximations of the correct value of fractional $\mathrm{Ca}$ absorption $[16,17]$. The reason for this is that absorption based on a spot urine or a single blood sample assumes that the intravenously injected isotope and the absorbed orally administered isotope will arrive in the blood stream at about the same time and are metabolized in parallel. Measurement of isotopes in a complete 24-h urine sample on the other hand, largely reflects the ratio of the areas under the plasma disappearance curves for the two isotopes [16] and is therefore much less dependent on the parallelity of the metabolic kinetics of the orally and intravenously administered isotopes. The measurement of Ca absorption, based on the 24-h urinary excretion of isotopes has been proved to be a valid method. Apparently there are no 
reasons to have any doubts about the validity of the method when, as is done in the present study, urine collection is extended to a 36 -h urine sample in order to include the colonic Ca absorption.

Nevertheless, we cannot exclude the possibility that the metabolic kinetics of $\mathrm{Ca}$ absorbed in the colon is different from that of $\mathrm{Ca}$ absorbed earlier in the duodenum or ileum or from that of the injected isotope, because of the time lag between the entrance of these doses in the blood and the existance of a diurnal rythm in the metabolism of $\mathrm{Ca}[18,19]$. Such a bias would however, not change the outcome of the present study, since such a bias would occur in both treatments.

If the only difference between the earlier and the present human study had been the duration of urine collection, we would have been able to speculate that most of the enhancement of $\mathrm{Ca}$ absorption due to FOS takes place in the large intestine. However besides age, allso the duration of adaptation to FOS consumption and the carrier dose of Ca given at breakfast with the stable isotopes were different.

In our earlier human study, $15 \mathrm{~g}$ of FOS per day was given for $18 \mathrm{~d}$ and breakfast contained of $513 \mathrm{mg}$ of $\mathrm{Ca}$ (see Chapter 6). In rats the increase in apparent $\mathrm{Ca}$ absorption after 8 or $18 \mathrm{~d}$ on a diet with NDO disappeared after $28 \mathrm{~d}$ [20]. Long-term feeding of lactose to Ca-repleted rats, which is also thought to enhance $\mathrm{Ca}$ absorption, resulted in a decrease in Ca-binding protein [21], indicating feed-back inhibition of the vitamin D-dependent Ca absorption component. As NDO feeding improves mineral retention especially in case of $\mathrm{Ca}$ deficiency [22], the superior $\mathrm{Ca}$ status of the rats [20] and of the young adult men in our earlier human study (see Chapter 6) could have diminished the increase in $\mathrm{Ca}$ absorption. This is not in accordance with the increase in apparent $\mathrm{Ca}$ absorption found by Coudray et al [6] in healthy adult men after $20 \mathrm{~d}$. However, they were given more than twice the dose of NDO than our subjects were given, which might have induced a higher effect.

The carrier dosage may also have influenced the results. When a higher carrier dose is administered, the active transport mechanism in the proximal intestine will be more readily saturated so that a relatively larger part of the absorption that is measured involves the paracellular pathway of $\mathrm{Ca}$ absorption, which occurs throughout the whole intestine. Besides, more $\mathrm{Ca}$ is likely to reach the distal intestine, where FOS 
may exert its positive effect. Therefore, one may expect a larger effect of FOS when a higher dose of carrier $\mathrm{Ca}$ is given. The question may be raised about the amount of $\mathrm{Ca}$ required in the carrier dose to include both active and passive $\mathrm{Ca}$ absorption. In this regard Kinyamu et al [23] found only a relation between serum $1,25(\mathrm{OH})_{2} \mathrm{D}$ and the $20 \mathrm{mg}$ Ca absorption test, but not when a carrier dose of $100 \mathrm{mg}$ Ca was given. This indicates that the larger $100 \mathrm{mg}$ carrier dose allows the measurement of both active and passive transport of Ca [23]. Also Sheikh et al [24] showed that the vitamin D-dependent mechanism is saturated or nearly saturated by low Ca meals of $120 \mathrm{mg}$. Consequently, in both our studies the active component was likely to be saturated and sufficient $\mathrm{Ca}$ has reached the distal intestine. To our knowledge only one rat experiment has been published on NDO with different $\mathrm{Ca}$ contents of the diet [25]. In contrast to the rats who were fed a normal-Ca diet, the rats fed a low-Ca diet with only $10 \%$ of the usual $\mathrm{Ca}$ contents did not reveal an $\mathrm{NDO}$-effect on $\mathrm{Ca}$ absorption or bone mineralization. Although the importance of the amount of $\mathrm{Ca}$ on the effect of NDO on Ca absorption in man should be further explored, we do not think the carrier doses used in both our studies made any difference, as it is likely that with both carrier doses, enough $\mathrm{Ca}$ will enter the colon to allow the positive effect of NDO on its absorption.

Ca absorption was not correlated with urinary Ca excretion, which is consistent with the results found in white girls and boys $[26,27]$. Apparently, during the period of bone development absorbed $\mathrm{Ca}$ is largely taken up by the bone tissue so that no relation between absorption and urinary excretion becomes apparent. The FOSinduced enhancement of $\mathrm{Ca}$ absorption was also not reflected by an increase of urinary $\mathrm{Ca}$ excretion. Also the enrichment of the ${ }^{48} \mathrm{Ca} /{ }^{43} \mathrm{Ca}$ ratio, and hence excretion of injected $\mathrm{Ca}$, was not affected by FOS. In rats a positive effect of non-digestible carbohydrates on bone development has been found $[20,22,25]$. Therefore, FOS may help to maximize the peak bone mass in adolescents.

In conclusion, $15 \mathrm{~g}$ of FOS per day increases Ca absorption in adolescent boys. The FOS-induced enhancement may be dependent on the subject's Ca requirement and may take place predominantly in the large intestine. 


\section{Acknowledgment}

Sources of support: European Union and ORAFTI s.a., Tienen, Belgium.

\section{References}

1 Roberfroid M. Dietary fiber, inulin, and oligofnctose: a review comparing their physiological effects. Crit Rev Food Sci Nutr 1993;33:103-148.

2 Gibson GR \& Roberfroid MB. Dietary modulation of the human colonic microbiota: introducing the concept of prebiotics. J Nutr 1995;125:1401-1412.

3 Ohta A, Ohtuki $M$, Takizawa $T$, Inaba $H$, Adachi $T$ \& Kimura $S$. Effects of fructo-oligosaccharides on the absorption of magnesium and calcium by cecectomized rats. Int $J$ Vitam Nutr Res 1994;64:316-323.

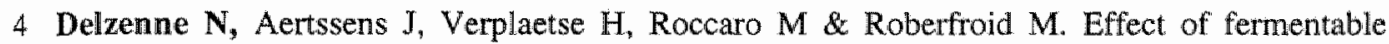
fructo-oligosaccharides on mineral, nitrogen and energy digestive balance in the rat. Life Sci $1995 ; 57: 1579-1587$.

5 Brommage $\mathbf{R}$, Binacua $\mathrm{C}$, Antille $\mathrm{S} \&$ Carrie AL. Intestinal calcium absorption in rats is stimulated by dietary lactulose and other resistant sugars. $J$ Nutr 1993;123:2186-2194.

6 Coudray C, Bellanger J, Castíglia-Delavaud C, Vermorel V \& Rayssignuier Y. Effect of soluble or partly soluble dietary fibres supplementation on absorption and balance of calcium, magnesium, iron and zinc in healthy young men. Eur J Clin Nutr 1997;51:375-380.

7 Ellegărd L, Andersson H \& Bosaeus I. Inulin and oligo-fructose do not influence the absorption of cholesterol, or the excretion of cholesterol, $\mathrm{Ca}, \mathrm{Mg}, \mathrm{Zn}$, Fe, or bile acids but increases energy excretion in ileostomy subjects. Eur J Clin Natr 1997;51:1-5.

8 Youmes $\mathbf{H}$, Demigné C \& Rémésy C. Acidic fermentation in the caecum increases absorption of calcium and magnesium in the large intestine of the rat. Br J Nutr 1996;75:301-314.

9 Barger-Lux MJ, Heaney RP \& Recker RR. Time course of calcium absorption in humans: evidence for a colonic component. Calcif Tissue Int 1989;44:308-311.

10 Van den Heuvel EGHM, Schaafsma G, Muijs T \& Van Dokkum W. Non-digestible oligosaccharides do not interfere with calcium and non-heme iron absorption in healthy young men. Am J Chin Nutr 1997 (in Press)

11 Van Dokkum W, De La Gueronniere V, Schatafsma $G$, Bouley C, Luten J \& Latge C. Bioavailability of calcium of fresh cheeses, enteral food and mineral water. A study with stable calcium isotopes in young adult women. Br J Nutr 1996;75:893-903.

12 Eastell R, Vieira NE, Yergey AL \& Riggs BL. One-day test using stable isotopes to measure true fractional calcium absorption. J Bone Miner Res 1989;4:463-468.

13 Nevo Foundation Editorial Board. Food composition table 1993-1994. The Hague: Krips Repro, 1994.

14 Luten JB, Muijs T \& Van Dokkum W. The determination of stable isotope ratio of zinc, copper, iron in faeces and calcium in urine by ICP-MS. In: Bioavailability 93. Nutritional, chemical and food processing implications of nutrient availability. Schlemmer $U$, ed. Karlsruhe: Bundesforschungsanstalt für Emährung, 1993:161-168. 
15 Statistical Analyses Systems. SAS/STAT User's Guide version 6, volume 2, 4th edit. Cary. NC: SAS Institute Inc. 1994.

16 Yergey AL, Abrams SA. Vieira NE, Aldroubi A, Marini J \& Sidbury IB. Determination of fractional absorption of dietary calcium in humans. J Nutr 1994;124:674-682.

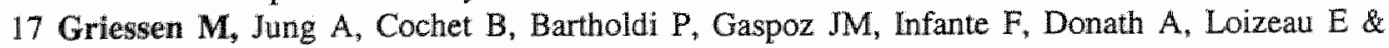
Courvoisier B. A simple method for measurement of intestinal calcium absorption in humans by double-isotope technique. J Lab Clin Med 1985; 105:641-646.

18 Greenspan SL, Dresner-Pollak R, Parker RA, London D \& Ferguson L. Diumal variation of bone mineral tumover in elderly men and women. Calcif Tissue Int 1997;60:419-423.

19 El-Haji Fuleihan G, Klerman EB, Brown EN, Choe Y, Brown EM \& Czeisler CA. The parathyroid hormone circadian thythm is truly endogenous- a clinical research center study. $J$ Clin Endocrinol Metab 1997:82:281-286.

20 Chonan O, Matsumoto K \& Watanuki M. Effect of galacto-oligosaccharides on calcium absorption and preventing bone loss in ovariectomized rats. Biosci Biotech Biochem $1995 ; 59: 236-239$.

21 Pansu D, Bellaton C \& Bronner F. Effect of Ca intake on saturable and nonsaturable components of duodenal Ca transport. Am J Physiol 1981;240:G32-G37.

22 Kashimura J, Kimura M \& Itokawa $Y$. The effects of isomaltulose-based oligomers feeding and calcium deficiency on mineral retention in rats. $J$ Nutr Sci Vitaminol 1996;42:69-76.

23 Kinyamu HK, Gallagher JC, Knezetic JA, Deluca HF, Prah1 JM \& Lanspa SJ. Effect of vitamin $\mathrm{D}$ receptor genotypes on calcium absorption, duodenal vitamin D receptor concentration, and serum 1,25 dihydroxyvitamin D levels in normal women. Calcif Tissue Int 1997;60:491-495.

24 Sheikh MS, Ramirez A, Emmett M, Santa Ana C, Schiller LR \& Fordtran JS. Role of vitamin D dependent and vitamin $\mathrm{D}$ independent mechanisms in absorption of food calcium. $J$ Clin Invest 1988;81:126-132.

25 Chonan 0 \& Watanuki M. The effect of 6'-galacto-oligosaccharides on bone mineralization of rats adapted to different levels of dietary calcium. Int $I$ Vitam Nutr Res 1996;66:244-249.

26 O'Brien KO, Abrams SA, Stuff JE, Liang LK \& Welch TR. Variables related to urinary calcium excretion in young girls. J Pediatr Gastroenterol Nwtr 1996;23:8-12.

27 Bell NH, Yergey AL, Vieira NE, Oexmann MJ \& Shary JR. Demonstration of a difference in urinary calcium, not calcium absorption, in black and white adolescents. J Bone Miner Res $1993 ; 8: 1 \rrbracket 11115$. 


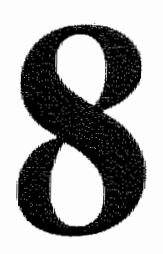

\section{Lactulose stimulates
postmenopausal women}

Ellen GHM van den Heuvel, Theo Muijs, Wim van Dokkum and Gertjan Schaafsma

\section{Abstract}

Animal studies have indicated that calcium absorption is increased by lactulose, a synthetic disaccharide. As no results of human studies on the influence of lactulose on calcium absorption are available, a study was conducted in postmenopausal women who may benefit from the envisaged enhancing effect of lactulose on calcium absorption. Twelve postmenopausal women drank $100 \mathrm{ml}$ water containing 5 or $10 \mathrm{~g}$ of lactulose or a reference substance at breakfast for $9 \mathrm{~d}$. The 3 treatments were given according to a randomized, double-blind, cross-over design, separated by two 19-d wash-out periods. On the 8 th day of each treatment period ${ }^{44} \mathrm{Ca}$ dissolved in orange juice was drunk immediately after the solution with the study substance and just before a standard breakfast with $162 \mathrm{mg}$ of carrier calcium. Within half an hour ${ }^{48} \mathrm{Ca}$ was given intravenously. Before and until $36 \mathrm{~h}$ after isotope administration urine was collected in which the isotope ratios were measured, from which true fractional calcium absorption was calculated. Calcium absorption during the treatments with the reference substance, $5 \mathrm{~g}$ and $10 \mathrm{~g}$ of lactulose was (mean $\pm \mathrm{SD}$ ) $27.7 \pm 7.7,30.0 \pm 7.6$ and $32.2 \pm 7.0$, respectively. A significant difference in calcium absorption was found between the highest dose of lactulose and the reference treatment $(\mathrm{P}<0.01)$. A significant linear trend was found between the dose of lactulose and its positive effect on calcium absorption.

In conclusion, lactulose increases calcium absorption in postmenopausal women. 
More research is warranted to explore how lactulose stimulates calcium absorption and whether it is able to improve calcium balance and/or to attenuate the rate of ageing bone loss.

\section{Introduction}

Lactulose is a synthetic disaccharide (4-0- $\beta$-D-galactopyranosyl-D-fructose, molecular weight 342.3 ) which does not exist in nature. It is produced in small amounts during heat treatment of milk. Lactulose can be made on large scale from lactose by alkaline isomerization in which galactose is linked to fructose as a $\beta \quad 1 \rightarrow 4$ glycoside $[1,2]$. It is not digested in the stomach/small intestine, but fermented in the colon by indigenous microflora. Due to fermentation, among other factors, shortchain fatty acids are produced and the $\mathrm{pH}$ decreases [3].

Animal studies have indicated that calcium (Ca) absorption is increased by lactulose, which appeared to be more effective than lactose [4] and pectin [5]. Apart from the possible influence of lactulose on the absorption of minerals in the small intestine through an improved solubility of $\mathrm{Ca}$, the route for absorption in the large intestine is of interest. Fermentation of undigested food components and, consequently, a lower colonic $\mathrm{pH}$ (because of the formation of short-chain fatty acids by the microflora) may have a positive effect on $\mathrm{Ca}$ absorption from the distal intestine.

This could be of special interest for post-menopausal women. The inverse effect of age on $\mathrm{Ca}$ absorption has been correlated with a decline in serum $1,25(\mathrm{OH})_{2} \mathrm{D}$ level [6] and thus the active component of absorption is decreased. By ingestion of nondigestible ingredients like lactulose, the rate of passive Ca absorption in the small or large intestine could be increased and the efficiency of Ca absorption in the elderly restored.

As no results of human studies on the influence of lactulose on Ca absorption are available, a study was conducted in a population group (postmenopausal women) who may benefit from the envisaged enhancing effect of lactulose on Ca absorption. The primary aim of this study was to investigate in postmenopausal healthy women the envisaged positive effect of the consumption of lactulose on true fractional absorption of $\mathrm{Ca}$. The secondary aim was to compare the effect of the ingestion of $5 \mathrm{~g}$ 
versus $10 \mathrm{~g}$ lactulose on true Ca absorption.

\section{Subjects and methods}

Subjects

Subjects were recruited from the pool of volunteers of TNO Nutrition and Food Research Institute and through an advertisement in a local newspaper. Twelve women were selected, who had been postmenopausal for at least 5 years based on a high level of follicle-stimulating hormone (FSH) and a low level of oestradiol (E2). At the start of the study their age ranged between 56 and 64 years (mean 60.5) and their BMI between 20.7 and 27.8 (mean 25.0). Eleven subjects had E2 values of $<20$ $\mathrm{pg} / \mathrm{ml}$. The levels of E2 and FSH of subject 7 were $60 \mathrm{pg} / \mathrm{ml}$ and $51 \mathrm{IU} / \mathrm{L}$, respectively. The FSH values of all subjects ranged between $5 \|$ and 121 (mean 89.6) IU/L. All subjects were certified to be in good general health by a staff physician and gave informed consent to participate in the study after procedures had been explained to them. The study protocol was approved by the TNO external Medical Ethics Committee.

Table 1 Composition of study substances

\begin{tabular}{lccc} 
& Placebo & $5 \mathrm{~g}$ lactulose & 10 g lactulose \\
\hline Lactulose (g) & - & 5 & 10 \\
Aspartame (mg) & 12.5 & 6.25 & - \\
Quinoline yellow & 0.04 & 0.02 & - \\
(mg) & 100 & 100 & 100 \\
Benzoic acid (mg) & 100 & 100 & 100 \\
Water (ml) & & & \\
\hline
\end{tabular}

Study design and execution of the study

The subjects were instructed to consume the study substance at breakfast during $9 \mathrm{~d}$ on top of their habitual food intake. The study substances consisted of $5 \mathrm{~g}$ or $10 \mathrm{~g}$ of lactulose or placebo dissolved in $100 \mathrm{ml}$ of water with benzoic acid. The exact composition is given in Table 1. Aspartame was selected as placebo; it was not 


\section{Chapter 8}

expected to interact with $\mathrm{Ca}$ absorption because of the small amount relative to lactulose and $\mathrm{Ca}$ and because aspartame is completely digested in the stomach/small intestine, so that no aspartame is present in the colon for any interaction with $\mathrm{Ca}$. A sensory panel found no difference in sourness and bitterness between the different study substances. The solution with $5 \mathrm{~g}$ lactulose was considered to be the most sweet solution followed by the placebo and the solution with $10 \mathrm{~g}$ lactulose.

The 3 treatments of 9 each were given according to a double-blind randomized cross-over design, separated by 19 -d wash-out periods. During the first $7 \mathrm{~d}$ of each treatment period the subjects consumed the study substances supplied at home. On the last two days the subjects were housed in the metabolic unit of the institute and the Ca absorption tests were carried out.

On Day 8, after a 12-h overnight fast, orange juice with ${ }^{44} \mathrm{Ca}$ was drunk immediately after the study substance and just at the start of a standard breakfast with $162 \mathrm{mg}$ of carrier $\mathrm{Ca}$, as measured with atomic absorption spectrometry (AAS). Within half an hour after the oral administration of ${ }^{44} \mathrm{Ca},{ }^{48} \mathrm{Ca}$ was injected intravenously. Before and after the bolus injection blood pressure and heart rate were recorded for safety reasons. The average quantity of isotopes given by each route, which was calculated by weighing the bottles or syringes before and after administration, was 13.9 (range 13.2 - 15.1) $\mathrm{mg}$ of ${ }^{44} \mathrm{Ca}$ and 1.15 (range $1.10-1.17$ ) $\mathrm{mg}$ of ${ }^{48} \mathrm{Ca}$. From the measurement of the ${ }^{44} \mathrm{Ca} /{ }^{43} \mathrm{Ca}$ and ${ }^{48} \mathrm{Ca} /{ }^{43} \mathrm{Ca}$ ratios in urine collected before dose administration and over the $36 \mathrm{~h}$ after dose administration, fractional $\mathrm{Ca}$ absorption was computed according to the formula reported by Van Dokkum et al [7].

\section{Preparation of stable isotope solutions}

The stable isotopes were obtained from NEDRAY (Bunschoten, Netherlands) in the form of $\mathrm{Ca}$ carbonate. The abundances of the different $\mathrm{Ca}$ isotopes according to analysis by inductively coupled plasma mass spectrometry (ICP-MS) were: $3.39 \%$ ${ }^{40} \mathrm{Ca}, 0.06 \%{ }^{42} \mathrm{Ca}, 0.03 \%{ }^{43} \mathrm{Ca}, 96.5 \%{ }^{44} \mathrm{Ca},<0.01 \%{ }^{46} \mathrm{Ca}, 0.02 \%{ }^{48} \mathrm{Ca}$ for Ca enriched in ${ }^{44} \mathrm{Ca}$, and $8.96 \%{ }^{40} \mathrm{Ca}, 0.09 \%{ }^{42} \mathrm{Ca}, 0.02 \%{ }^{43} \mathrm{Ca}, 0.24 \%{ }^{44} \mathrm{Ca},<0.01 \%{ }^{46} \mathrm{Ca}, 90.69 \%$ ${ }^{48} \mathrm{Ca}$ for $\mathrm{Ca}$ enriched in ${ }^{48} \mathrm{Ca}$. The ${ }^{44} \mathrm{Ca}$ carbonate was converted into chloride salt, diluted with deionized water, followed by $\mathrm{pH}$ adjustment to 5 . A similar procedure 
was followed for ${ }^{48} \mathrm{Ca}$ carbonate, except that saline was used instead of deionized water. After filtration the solution was distributed over $10 \mathrm{ml}$ injection bottles and sterilized for $25 \mathrm{~min}$.

Stable isotope analysis

The $\mathrm{Ca}$ isotope ratios ${ }^{44} \mathrm{Ca} /{ }^{43} \mathrm{Ca}$ and ${ }^{48} \mathrm{Ca} /{ }^{43} \mathrm{Ca}$ in urine were measured by ICP-MS after protein precipitation with $3.5 \%$ trichloroacetic acid, precipitation of $\mathrm{Ca}$ with saturated ammonium oxalate and dissolution of the Ca oxalate formed into $1.2 \mathrm{M} \mathrm{HCl}$ [8].

The $\mathrm{Ca}$ concentration in the $\mathrm{HCl}$ solution was measured by $\mathrm{AAS}$ and, if necessary, diluted to adjust to $\mathrm{ca} .10 \mu \mathrm{g} / \mathrm{ml} \mathrm{Ca}$. Urine spot samples and $36-\mathrm{h}$ urine samples taken before and after isotope administration of the same subject were tested within one day, together with a blank and a standard of $10 \mu \mathrm{g} / \mathrm{mll}$ Ca. All values were adjusted for minor deviations from standard Ca solutions with accepted natural ratios. All samples were measured in duplicate.

\section{Statistics}

The differences in Ca absorption among treatments were tested by ANOVA in a Latin square design. Also the presence of linear or quadratic trends was tested [9].

Table 2 The enrichment of ${ }^{44} \mathrm{Ca} /{ }^{43} \mathrm{Ca}$ and ${ }^{48} \mathrm{Ca} /{ }^{43} \mathrm{Ca}$ ratios and $\mathrm{Ca}$ absorption per treatment $($ mean $\pm S D)$

\begin{tabular}{lrcc}
\hline & Placebo & 5 g lactulose & $10 \mathrm{~g}$ lactulose \\
\hline Enrichment (\%) & & & \\
$-{ }^{44} \mathrm{Ca} /{ }^{43} \mathrm{Ca}$ ratio & $3.7 \pm 0.8$ & $4.2 \pm 1.1^{1}$ & $4.5 \pm 0.8^{2}$ \\
$-{ }^{48} \mathrm{Ca} /{ }^{43} \mathrm{Ca}$ ratio & $13.0 \pm 1.9$ & $13.4 \pm 1.7$ & $13.7 \pm 2.2$ \\
& & & \\
\hline
\end{tabular}

${ }^{5} \mathrm{P}<0.05$ compared to placebo; ${ }^{2} \mathrm{P}<0.0 \mathrm{l}$ compared to placebo

If the ANOVA indicated a treatment effect $(\mathrm{P}<0.05)$, the control treatment and the treatment with lactulose were compared with Student's t-test. Regression analyses 
was used to assess associations between variables.

\section{Results}

All subjects completed the study. Based on the number of returned bottles without the study substance and the check of compliance via a questionnaire, compliance was considered to be very good. None of the subjects ever forgot to drink the orange juice with the study substance.

Because the basal urine sample of subject 6 collected on Day 8 was too small, the ICP-MS analysis of this urine sample was not performed in duplicate. All the other urine samples were measured in duplicate. The within-duplicate coefficient of variation $\left(\mathrm{CV}\right.$ ) for the ${ }^{44} \mathrm{Ca} /{ }^{43} \mathrm{Ca}$ ratio was $0.26 \%$ and in the $\mathrm{CV}$ for the ${ }^{48} \mathrm{Ca} /{ }^{43} \mathrm{Ca}$ ratio was $0.33 \%$.

Figure 1 Change in Ca absorption $\%$ due to lactulose (mean \pm SEM).

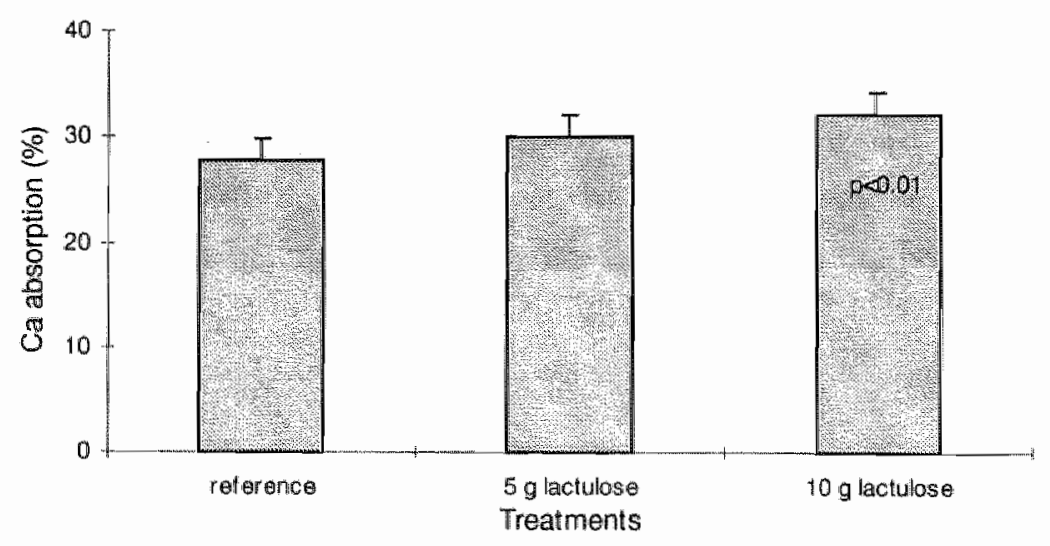

The average basal ${ }^{44} \mathrm{Ca} /{ }^{43} \mathrm{Ca}$ ratio $(\mathrm{n}=36)$ was $15.449(\mathrm{CV} 0.37 \%)$ and the ${ }^{48} \mathrm{Ca} /{ }^{43} \mathrm{Ca}$ ratio 1.393 ( $\mathrm{CV} 0.74 \%$ ). Table 2 shows the mean enrichment percentages of the ${ }^{44} \mathrm{Ca} /{ }^{43} \mathrm{Ca}$ and ${ }^{48} \mathrm{Ca} /{ }^{43} \mathrm{Ca}$ ratios per treatment. In Figure 1 the mean absorption percentages per treatment are shown.

$\mathrm{Ca}$ absorption was significantly higher during the consumption of $10 \mathrm{~g}$ lactulose per 
day than during the placebo treatment $(\mathrm{P}<0.01)$. A significant linear trend was found between the dose of lactulose and its positive effect on $\mathrm{Ca}$ absorption $(\mathrm{P}=0.003)$. A significant correlation was found between $\mathrm{Ca}$ absorption and total amount of $\mathrm{Ca}$ excreted in 36-h urine $(y=5.8 x+51.6 ; r=0.51 ; P<0.01)$. Total Ca excretion in 36-h urine did not differ significantly between treatments $(P=0.69)$.

\section{Discussion}

The measurement of fractional absorption of $\mathrm{Ca}$ from a 24-h urine collection after oral and intravenous administration of two different $\mathrm{Ca}$ isotopes has been shown to be an accurate and reliable technique $[10,11]$. In the present study this method was used to study the effect of lactulose on $\mathrm{Ca}$ absorption. However, since lactulose and other non-digestible carbohydrates are hardly absorbed in the small intestine but fermented in the terminal ileum and the large intestine (caecum, colon), and since acidic fermentation in the large intestine may improve $\mathrm{Ca}$ absorption at this site [12], the collection of urine was extended to $36 \mathrm{~h}$ (see also Chapter 7).

Until now, the effect of lactulose on Ca absorption has only been studied in rat experiments, in which a positive effect of lactulose on $\mathrm{Ca}$ absorption was found $[4,5$, 13]. The positive effect of lactulose on $\mathrm{Ca}$ absorption appears to be non-specific and is shared, at least in rats, by other non-digestible carbohydrates [4].

In our study the effect of 5 or $10 \mathrm{~g}$ lactulose on Ca absorption was compared with a placebo treatment in 12 postmenopausal women who did not suffer from any adverse side-effect of lactulose. Like Brommage et al [4], we found a significant linear increase in $\mathrm{Ca}$ absorption with a higher dose of lactulose. In rats the effect of lactulose was not further increased by rising the dietary concentration from 10 to 15\%. Possibly a decrease in vitamin D-dependent active Ca transport can counterballance the lactulose-induced increase in passive $\mathrm{Ca}$ absorption [4]. In rats $15 \%$ dietary lactulose also could have adversely influenced gastro-intestinal function by causing diarrhoea. It is not known yet whether a higher lactulose intake than 10 $\mathrm{g} / \mathrm{d}$ further raises $\mathrm{Ca}$ absorption in man or whether this effect is counterbalanced. Brommage et al [4] found a positive acute effect of lactulose on $\mathrm{Ca}$ absorption in rats. This effect was lost after a few days of adaptation to $5 \%$ of lactulose. Other groups 
found that $10 \%$ of lactulose increased $\mathrm{Ca}$ absorption, even after 3 weeks of adaptation [5, 13]. We found a significant positive effect of $10 \mathrm{~g}$ lactulose and a nonsignificant positive effect of $5 \mathrm{~g}$ lactulose on $\mathrm{Ca}$ absorption after 1 week of adaptation. This one-week adaptation may have slightly reduced the positive effect, leading to a non-significance of the increase in $\mathrm{Ca}$ absorption due to $5 \mathrm{~g}$ of lactulose. Two mechanisms of Ca absorption exist: (1) 'active" trans-cellular absorption (mainly in duodenum and largely regulated by vitamin D) and (2) "passive" para-cellular transport across the small and large intestine [14]. Several theories have been proposed to explain the stimulatory effect of lactulose and non-digestible oligosaccharides on intestinal $\mathrm{Ca}$ absorption. These theories refer to effects on passive, trans-and/or para-cellular $\mathrm{Ca}$ absorption in the small and/or large intestine. Observations that the action of lactulose and calcitriol is additive indicates that lactulose stimulates the passive rather than the vitamin D-dependent, active component of Ca absorption [4]. Also Demigné \& Rémésy [15] ascribed the rise of $\mathrm{Ca}$ absorption after a high-fibre diet with non-digestible carbohydrates to a passive process.

Transcellular transport of Ca may be stimulated by short-chain fatty acids. In man, an increased production of SCFA in the caecum [3] and an increased concentration of serum acetate have been found after the ingestion of lactulose [16]. The direct effect probably involves diffusion of protonated SCFA across the apical membrane. In the cell the protonated SCFA molecule dissociates, resulting in an increased intracellular $\mathrm{H}^{+}$which is secreted from the cell in exchange for $\mathrm{Ca}^{2+}$ from the distal colon. Once outside the cell, $\mathrm{H}^{+}$becomes available to protonate a SCFA to diffuse into the cell $[17,18]$. This enhancing effect of SCFA seems to occur in the distal but not in the proximal colon [17]. Whether this process involves passive or active transport needs fo be further investigated.

Paracellular $\mathrm{Ca}$ absorption may be stimulated by $\mathrm{pH}$ reduction. In man the fermentation of lactulose $(40 \mathrm{~g} / \mathrm{d})$ also results in a lower caecal fluid $\mathrm{pH}$ [3]. The $\mathrm{pH}$ reduction is associated with an increased amount of soluble $\mathrm{Ca}$ in the caecum of rats given non-digestible oligosaccharides $[19,20]$. Also in the ileal lumen of the rat, lactulose caused a reduction of the ileal $\mathrm{pH}$ (from 7.5 to 7.0). This might have caused 
an increased $\mathrm{Ca}$ absorption in rats, because a negative relation was found between ileal pH and apparent absorption of minerals [13].

Another hypothesis on the mechanism by which osmotically active sugars in the small intestine stimulate paracellular Ca absorption is the increased amount of fluid within the lumen to maintain isotonicity. This additional fluid might increase the distention and permeability of the intercellular junctions between enterocytes, thereby increasing passive para-cellular absorption of $\mathrm{Ca}$ and other elements [4].

As lactulose increases $\mathrm{Ca}$ absorption without increasing urinary $\mathrm{Ca}$ excretion (this study), lactulose may also increase the uptake of $\mathrm{Ca}$ by the bones and/or inhibit bone resorption. This is underscored by the fact that in rats a positive effect of nondigestible carbohydrates on bone development was found [21-23]. Thus lactulose may help to reduce the negative $\mathrm{Ca}$ balance in postmenopausal women. However, this should be confirmed by further experimental research before a final conclusion can be drawn.

In conclusion, lactulose increases $\mathrm{Ca}$ absorption in postmenopausal women, without increasing urinary $\mathrm{Ca}$ excretion. The positive effect on $\mathrm{Ca}$ absorption is significantly related to the dose of lactulose. More research is warranted to explore how lactulose stimulates $\mathrm{Ca}$ absorption and whether it is able to improve Ca balance in man and/or to decrease the rate of ageing bone loss.

\section{Acknowledgements}

Sources of support: Solvay Pharmaceuticals, Strategic Marketing U'nit Gastroenterology, Hannover, Germany

\section{References}

1 Mizota T, Tamura Y, Tomita M \& Okonogi S. Lactulose as a sugar witl physiological significance. Bull Int Dairy Fed 1987;212:69-76.

2 Mendez A \& Olano A. Lactulose. A review of some chemical properties and applications in infant nutrition and medicine. Dairy Science Abstracts 1979;41:531-535.

3 Florent C, Flourie B, Leblond A, Rautureau M, Bernier JJ \& Rambaud JC. Infiuence of chronic lactulose ingestion on the colonic metabolism of lactulose in man (an in vivo study). $J$ Clin Invest 1985:75:608-613. 
4 Mrommage $R$, Binacua $C$, Antille $S$ \& Carrie AL Intestinal calcium absorption in rats is stimulated by dietary lactulose and other resistant sugars. $J$ Nut 1993,123:2186-2194.

5 Demignê $C$, Lewrat MA \& Rénésy $C$. Effects of feeding fermentable carbohydrates on the cecal concentrations of minerals and their fluxes between the cecum and blood plasma in the rat. $J$ Nut 1989;119:1625-1630.

6 Armbrecht HJ. Changes in intestinal calcium absorption and witamin D metabolism with age.

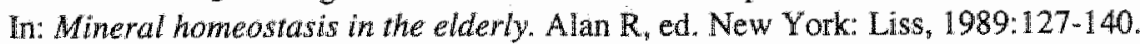

7 Van Dokkum W, De La Gueronniere V, Schafsma G, Bouley $C$, Luten J \& Latge C. Bioavailability of calcium of fresh cheeses, enteral food and mineral water. A study with stable calcium isotopes in young adult women. Br J Nutr 1996;75:893-903.

8 Luten JB, Muijs T \& Van Dokkum W. The determination of stable isotope ratio of zinc, copper, iron in faeces and calcum in urine by ICP-MS. In: Bioavailability '93. Nutritional, chemical and food processing implications of nutrient availability. Schlemmer U, ed. Karlsruhe: Bundesforschungsanstalt für Ernährung, 1993:161-168.

9 Statistical Analyses Systems. SAS/STAT User's Guide version 6, volume 2. 4th edit. Cary, NC: SAS Institute Inc. 1994.

10 Vergey AL, Abrams SA, Vieira NE, Aldroubi A, Marini J \& Sidbury JB. Determination of fractional absorption of dietary calcium in humans. $J$ Nutr 1994;124:674-682.

11 Griessen M, Jung $A$, Cochet B, Bartholdi P. Gaspoz JM, Infante F, Donath A, Loizeau E \& Courvoisier B. A simple method for measurenent of intestinal calcium absorption in humans by double-isotope technique. J Lab Clin Med 1985; 105:641-646.

12 Younes $\mathrm{H}$, Demigné $\mathrm{C}$ \& Rémésy $\mathrm{C}$. Acidic fermentation in the caecum increases absorption of calcium and magnesium in the large intestine of the rat. Br J Nutr 1996;75:301-314.

13 Heijnen AM, Brink EJ, Lemmens AG \& Beymen AC. Ileal pH and apparent absorption of magnesium in rats fed on diets containing either lactose or lactulose. Br J Nurr 1993;70:747-756.

14 Bromner F. Calcium. In: Handbook of nutritionally essential mineral elements. O'Dell BL, Sunde RA., eds. New York: Marcel Dekker, Inc. 1997: 13-62.

15 Demigne $\mathrm{C}$ \& Rénésy $\mathrm{C}$. Stimulation of absorption of wolatile fatty acids and minerals in the cecum of rats adapted to a very high fiber diet. I Nutr 1985;115:53-60.

16 Wolever TM, Robb PA. Ter Wal P \& Spadafora PG. Interaction between methane-producing status and diet on serum acetate concentration in humans. J Nutr 1993;123:681-688.

17 Iuta $T$ \& Scharrer E. Effect of short-chain fatty acids on calcium absorption by the rat colon. Exp Physiol 1991:76:615.618.

18 Trinidad TP, Wolever TM \& Thompson LU. Effect of acetate and propionate on calcium absorption from the rectum and distal colon of humans. Am J Clin Nutr 1996;63:574-578.

19 Chonan $O$ \& Waranuki M. Effect of galacto-oligosaccharides on calcium absorption in rats. $J$ Nutr Sci Viraminol 1995;41:95-104.

20 Ohta A, Ohtsuki M, Baba S, Takizawa $T$, Adachi $T$ \& Kimura $S$. Effects of fructo-oligosaccharides on the absorption of iron, calcium and magnesium in iron-deficient anemic rats. J Nutr Sci Virominol 1995; $41: 281-291$.

21. Chonan 0, Matsumoto $\mathrm{K} \&$ Watanuki M. Effect of galacto-oligosaccharides on calcium absorption and preventing bone lloss in ovariectomized rats. Biosci Biotech Biochem $1995 ; 59: 236-239$. 
22 Chonan $O \&$ Watanuki M. The effect of 6 -galacto-oligosaccharides on bone mineralization of rats adapted to different levels of dietary calcium. Int J Vitam Nutr Res 1996;66:244-249.

23 Kashimura $J$, Kimura $M$ \& Itokawa $Y$. The effects of isomaltulose-based oligomers feeding and calcium deficiency on mineral retention in rats. I Nutr Sci Vitaminol 1996;42:69-76. 
124 


\section{9}

\section{Feasibility of using stable magnesium isotopes in humans: effect of fructo-oligosaccharides in adolescents}

Ellen GHM van den Heuvel, Theo Muijs, Wim van Dokkum and Gertjan Schaafsma

\section{Abstract}

The aim of the present study was first to test the application of the inductively coupled plasma mass spectrometry (ICP-MS) to measure enrichments of $\mathrm{Mg}$ isotope ratios in urine. The second aim was to investigate whether $15 \mathrm{~g}$ of FOS per day stimulates magnesium absorption in boys, using stable $\mathrm{Mg}$ isotopes.

Using ICP-MS, we were able to measure validly, with a high precision $(\mathrm{CV}<1.0 \%)$, an enrichment of the ${ }^{25} \mathrm{Mg} /{ }^{24} \mathrm{Mg}$ and ${ }^{26} \mathrm{Mg} /{ }^{24} \mathrm{Mg}$ ratios between 1 and $10 \%$. Subsequently, seven subjects aged between 14 to 16 y received, for $9 \mathrm{~d}, 15 \mathrm{~g}$ of FOS or sucrose (control treatment) spread over the day. The treatments were given according to a randomized, double-blind, cross-over design, separated by a 19-d wash-out period. Assuming that FOS have no effect on the kinetics of absorbed $\mathrm{Mg}$, the effect of FOS on absorption was investigated by the measurement of urinary excretion of ${ }^{25} \mathrm{Mg}$, orally administered on the 8 th day of each treatment period. In the FOS-condition, the mean urinary ${ }^{25} \mathrm{Mg}$ excretion $( \pm$ SEM) increased from $3.48 \pm$ $0.46 \%$ to $4.11 \pm 0.60 \%$, albeit no significant change in $\mathrm{Mg}$ absorption was found $(\mathrm{P}=$ 0.174 , one-sided).

In conclusion, with stable $\mathrm{Mg}$ isotopes it is possible to follow effects of dietary 
constituents on $\mathrm{Mg}$ metabolism. Since this study was performed only with an oral administration of a stable isotope and not by the application of a dual stable isotope technique (oral and intravenous administration), no final conclusion about the potential effect of FOS on $\mathrm{Mg}$ absorption can be drawn.

\section{Introduction}

The capability of the human body to conserve very efficiently the plasma $\mathrm{Mg}$ concentration in a wide range of $\mathrm{Mg}$ intakes by modulation of the tubular reabsorption of $\mathrm{Mg}$ in the kidneys, raises the question what impact dietary components which influence $\mathrm{Mg}$ bioavailability may have [1]. However, at low intakes of $\mathrm{Mg}$ dietary components are important, because then differences in $\mathrm{Mg}$ absorption may be expected to influence $\mathrm{Mg}$ retention and thus these components can either abolish or induce $\mathrm{Mg}$ deficiency [2].

Fructo-oligosaccharides (FOS) are non-digestible oligosaccharide that escapes digestion in the stomach and small intestine of humans and consequently arrive quantitatively in the large intestine [3]. It has been proposed that FOS raise the absorption of $\mathrm{Mg}$ by increasing the soluble pool of the mineral through fermentation of the non-digestible oligosaccharides in the large intestine [4, 5]. Moreover, the short-chain fatty acids (SCFA) produced during fermentation of the non-digestible oligosaccharides may enhance $\mathrm{Mg}$ absorption by a $\mathrm{Mg}^{2+} / \mathrm{H}^{+}$exchanger located in the apical membrane of the epithelium in the distal colon $[6,7]$. Whatever the mechanism, FOS enhances apparent Mg absorption in rats [4, 8-10].

In the present study we wanted to investigate whether $15 \mathrm{~g}$ of FOS per day stimulates true absorption of $\mathrm{Mg}$ and $\mathrm{Ca}$ in young growing male volunteers. The results of $\mathrm{Ca}$ absorption are shown in Chapter 7. True $\mathrm{Mg}$ absorption can be estimated by performing isotope measurements in urine or plasma when an oral dose of ${ }^{26} \mathrm{Mg}$ is given together with the intravenous administration of radiomagnesium ${ }^{28} \mathrm{Mg}$ [11]. Recently, this dual-isotope procedure has been modified to one using two stable isotopes of $\mathrm{Mg}$ [12]. From the ratio of isotope excess of the orally and intravenously administered isotope in blood (serum/plasma) or urine samples, taken after simultaneous administration of the isotopes, absorption can be determined. 
The aim of the present study was first to test the application of the inductively coupled plasma mass spectrometry (ICP-MS) to measure enrichments of $\mathrm{Mg}$ isotope ratios in urine. The second aim was to investigate whether $15 \mathrm{~g}$ of FOS per day stimulates magnesium absorption in boys, using stable $\mathrm{Mg}$ isotopes. Because of problems with the quality and quantity of the $\mathrm{Mg}$ isotopes delivered to the institute, only 7 subjects were given orally ${ }^{25} \mathrm{Mg}$. No intravenous administration took place.

\section{Materials and methods}

\section{ICP-MS analyses}

The ICP-MS used was a Perkin Elmer Sciex (Elan 500). All measurements were carried out in isotope ratio peak hopping mode. The ICP-MS was operated in the high resolution mode to provide maximal accuracy. Typical conditions for operations were: plasma power $1.2 \mathrm{~kW}$, reflected power $<5 \mathrm{~W}$, plasma flow rate 1.2 , nebuliser flow rate 60 , auxiliary Ar-flow rate 18 , dwell time $20 \mathrm{msec}, 1$ measurement per peak and 10 repeats per integration, total measuring time $270 \mathrm{sec}$.

A Mg standard solution (Titrisol, Merck) of $1 \mathrm{mg}$ of $\mathrm{Mg} / \mathrm{ml}$ was used as a base for the working standards for the determinations of total $\mathrm{Mg}$ and the baseline isotope ratios in all ICP-MS analyses. For the validation study aliquots of urine samples were enriched by the addition of ${ }^{25} \mathrm{MgCl}$ or ${ }^{26} \mathrm{MgCl}$ to yield enrichment levels of 1,5 and $10 \%$ in excess of natural abundance.

These artificially enriched urine samples and the biologically enriched urine samples obtained from the human experiment were prepared as follows. First calcium chloride, ammonium phosphate and an ammonia solution were added to the urine samples to enclose $\mathrm{Mg}$ into calcium phosphate. After centrifugation, the supernatant was discarded and the remaining pellet was dissolved in $\mathrm{HNO}_{3}$ [13].

The prepared urine samples taken during each treatment before and after isotope administration for the same subject were measured by ICP-MS within one day, together with standard solutions of $1.0 \mu \mathrm{g} / \mathrm{ml} \mathrm{Mg}$ and blank solutions. All values were adjusted for minor deviations from standard $\mathrm{Mg}$ solutions with accepted natural ratios and were measured in duplicate. 


\section{Preparation stable isotope}

The stable isotopes ${ }^{25} \mathrm{Mg}$ and ${ }^{26} \mathrm{Mg}$ were obtained as MgO (NEDRAY, Bunschoten, Netherlands). The ${ }^{25} \mathrm{Mg}$ and ${ }^{26} \mathrm{Mg}$ preparations used for the calibration study were both enriched to $>97 \%$. For the human experiment with FOS the abundance of the ${ }^{25} \mathrm{Mg}$ preparation according to ICP-MS analysis was: $1.9 \%{ }^{24} \mathrm{Mg}, 97.1 \%{ }^{25} \mathrm{Mg}, 1.0 \%$ ${ }^{26} \mathrm{Mg}$. The ${ }^{26} \mathrm{Mg}$ preparation, however, appeared not to be enriched with ${ }^{26} \mathrm{Mg}$. The natural abundances of stable $\mathrm{Mg}$ isotopes are $78.99 \%{ }^{24} \mathrm{Mg}, 10.00 \%{ }^{25} \mathrm{Mg}$ and $11.01 \%{ }^{25} \mathrm{Mg}[14]$.

We decided to perform the study without an intravenous administration and just investigate the effect of FOS on urinary excretion of the orally given ${ }^{25} \mathrm{Mg}$. If we assume that FOS do not affect the excretion of the absorbed ${ }^{25} \mathrm{Mg}$, the urinary excretion of the orally given ${ }^{25} \mathrm{Mg}$ still would enable us to investigate qualitatively the effect of FOS on $\mathrm{Mg}$ absorption.

The $\mathrm{Mg}$ oxide was dissolved in chloric acid ( $0.1 \mathrm{M})$, followed by $\mathrm{pH}$ adjustment to 5 . After filtration the solution was distributed over $10 \mathrm{ml}$ vials and sterilized for 15 minutes at $121^{\circ} \mathrm{C}$.

\section{Human experiment: fructo-oligosaccharides and $\mathrm{Mg}$ metabolism}

Twelve healthy boys were selected for the study in which the effect of FOS on Ca absorption (see Chapter 7) and $\mathrm{Mg}$ metabolism was examined. The subjects were recruited through an advertisement in a local newspaper. Normal health was assessed at pre-study screening, which included a medical history, physical examination, measurement of blood pressure and heart rate and routine clinicall laboratory tests. The study protocol was approved by the TNO external Medical Ethics Committee. All subjects and their parents signed informed consent forms.

Due to problems with the $\mathrm{Mg}$ isotopes, only 7 subjects participated in the $\mathrm{Mg}$ study. At the start of the study their age ranged between 14 and $16 \mathrm{y}$ (mean 15.1) and BMI between 16.0 and $20.7 \mathrm{~kg} / \mathrm{m}^{2}$ (mean 18.5 ).

The subjects were asked to keep their habitual food intake during the study as constant as possible, but to restrict consumption of fibre-rich and oligosaccharidecontaining food products. During the two 9-d treatment periods subjects drank 3 
times (at breakfast, lunch and dinner) $100 \mathrm{ml}$ of orange juice containing $5 \mathrm{~g}$ of FOS (Raftilose $\otimes P 95)$ or the reference substance. As the pure oligosaccharide content of Raftilose $\circledast \mathrm{P} 95$ was ca. $90 \%$, the weight of FOS was adjusted for a constant intake of $5 \mathrm{~g}$ of pure FOS. The reference substance consisted of fine-powdered sucrose. Both drinks with the study substance had the same sweetness due to addition of aspartame. The treatments were given to the subjects according to a randomized cross-over design. This strictly controlled study was executed in a 'double-blind' mode.

During the first $7 \mathrm{~d}$ of each treatment period the subjects consumed the study substances supplied at home. On the last two days of each treatment period the subjects were housed in the metabolic unit of the Institute, where a standardized diet was supplied. On the 8th day of each treatment period, after a 12-h overnight fast, the orange juice, containing ${ }^{25} \mathrm{Mg}$ next to the study substance, was given with a standard breakfast (with ca. $40 \mathrm{mg}$ of carrier $\mathrm{Mg}$ ). The exact quantity of ${ }^{25} \mathrm{Mg}$ given, as calculated by weighing the bottles before and after isotope administration, amounted 51.4 (range $48.0-54.0$ ) $\mathrm{mg}$. Until $4 \mathrm{~h}$ after oral administration of the stable isotopes, no food or drinks were allowed except for water. In the urine samples collected before and for $36 \mathrm{~h}$ after dose administration the ${ }^{25} \mathrm{Mg} /{ }^{24} \mathrm{Mg}$ ratio was measured.

\section{Treatment of data}

The percentage of isotope enrichment was calculated as 100 times the difference between the basal ratio and the enriched ratio divided by the basal ratio. The expected and measured percentage of isotope enrichment levels were compared by regression analysis.

Excretion as a percentage of the orally administered dose was calculated using the following formula:

Excretion $(\%)=$

$$
{ }_{\Delta^{25}} \mathrm{Mg} /{ }^{24} \mathrm{Mg} \text { x na of }{ }^{24} \mathrm{Mg} \times \mathrm{TMg}
$$

$$
{ }^{25} \mathrm{Mg}
$$

where $\quad \mathrm{na}=$ natural abundance of ${ }^{24} \mathrm{Mg}=78.99 \%$

Tmg = total Mg (mg) in 36-h urine 
The FOS-induced difference in ${ }^{25} \mathrm{Mg}$ excretion was evaluated by an unbalanced ANOVA [15], to be able to correct for the non-orthogonality and to include the advantages of a cross-over design. On the basis of rat experiments which all showed a positive effect of FOS on $\mathrm{Mg}$ absorption, and since Coudray et al [16] did not find a negative effect of another non-digestible oligosaccharide on apparent $\mathrm{Mg}$ absorption in humans, we performed a one-sided statistical test (positive effect vs. no effect).

\section{Results}

\section{Precision and validation of isotope ratio measurement}

The reproducibility of the ICP-MS was estimated, using standard Mg-solutions. The mean ${ }^{25} \mathrm{Mg} /{ }^{24} \mathrm{Mg}$ and ${ }^{26} \mathrm{Mg} /{ }^{24} \mathrm{Mg}$ ratios in these standards measured on $2 \mathrm{~d}(\mathrm{n}=20)$ were 0.1318 and 0.1512 , respectively. Within-day variation (coefficient of variation) was $0.35 \%$ for the analyses of the ${ }^{25} \mathrm{Mg} /{ }^{24} \mathrm{Mg}$ ratio and was $0.47 \%$ for the ${ }^{26} \mathrm{Mg} /{ }^{24} \mathrm{Mg}$ ratio. Between-day variation was $1.27 \%$ for the ${ }^{25} \mathrm{Mg} /{ }^{24} \mathrm{Mg}$ ratio and was $1.17 \%$ for the ${ }^{26} \mathrm{Mg} /{ }^{24} \mathrm{Mg}$ ratio.

Figure 1 shows that we were able to measure validly in urine samples an enrichment between 1 and $10 \%$ for both the ${ }^{25} \mathrm{Mg} /{ }^{24} \mathrm{Mg}$ and ${ }^{26} \mathrm{Mg} /{ }^{24} \mathrm{Mg}$ ratio. Mean precision of the isotope measurements in 8 samples containing $0-10 \%{ }^{25} \mathrm{Mg}$ and ${ }^{26} \mathrm{Mg}$ excess was $0.62 \%$ for the ${ }^{25} \mathrm{Mg} /{ }^{24} \mathrm{Mg}$ ratio and $0.86 \%$ for the ${ }^{26} \mathrm{Mg} /{ }^{24} \mathrm{Mg}$ ratio per duplicate set.

The correlation coefficients were similar for both ${ }^{25} \mathrm{Mg}$ and ${ }^{26} \mathrm{Mg}$. However, the consistent negative difference between the expected and measured ${ }^{26} \mathrm{Mg} /{ }^{24} \mathrm{Mg}$ ratio isotope ratios suggests a small systematic error. We were unable to identify its source.

Human experiment: fructo-oligosaccharides and $\mathrm{Mg}$ metabolism

Table 1 shows the mean $\mathrm{Mg}$ data per treatment. No significant differences were found between the two treatments. 
Figure 1 Regression of expected and measured enrichment of the ${ }^{25} \mathrm{Mg} /{ }^{24} \mathrm{Mg}$ (a) and ${ }^{26} \mathrm{Mg} /{ }^{24} \mathrm{Mg}$ (-) ratios in urine samples spiked with a known amount of ${ }^{25} \mathrm{Mg}$ or ${ }^{26} \mathrm{Mg}$ chloride.

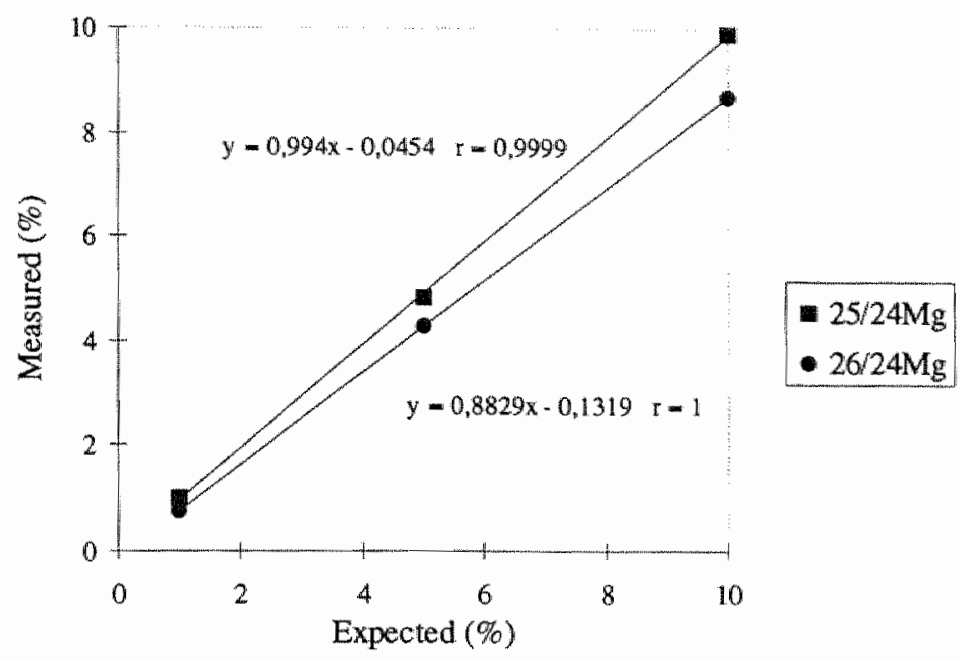

Table 1 The ${ }^{25} \mathrm{Mg}^{24} \mathrm{Mg}$ ratio, enrichments and excretion per treatment (mean $\left.\pm \mathrm{SD}\right)^{1}$

${ }^{25} \mathrm{Mg} /{ }^{24} \mathrm{Mg}$ ratio

- Basal

$0.1271 \pm 0.001$

$0.1271 \pm 0.001$

- Enriched

$0.1375 \pm 0.003$

$0.1391 \pm 0.003$

Enrichment (\%) of

${ }^{25} \mathrm{Mg}{ }^{24} \mathrm{Mg}$ ratio (range)

${ }^{25} \mathrm{Mg}$ excretion (\% of oral dose) $\mathrm{n}=7$

A significant correlation was found between the ${ }^{25} \mathrm{Mg}$ excretion ( $\%$ of dose) and the total amount of $\mathrm{Mg}$ excreted in 36-h urine $(y=0.02 x+0.16, r=0.74, P<0.01)$. The total amount of $\mathrm{Mg}$ in the 36 -h urine was $222 \pm 62$ and $225 \pm 71 \mathrm{mg}$ for the reference substance and the FOS-condition, respectively. 
Between the excretion of the orally administered ${ }^{44} \mathrm{Ca}$ and ${ }^{25} \mathrm{Mg}$ a significant correlation was found $(y=0,36 x-0,37, r=0.72, P<0.05)$. In Figure 2 the effect of FOS on both the urinary excretion of ${ }^{44} \mathrm{Ca}$ and ${ }^{25} \mathrm{Mg}$ per subject is shown.

Figure 2 The FOS-induced change in the excretion of ${ }^{44} \mathrm{Ca}$ and ${ }^{25} \mathrm{Mg}$ expressed as a percentage of the oral dose.

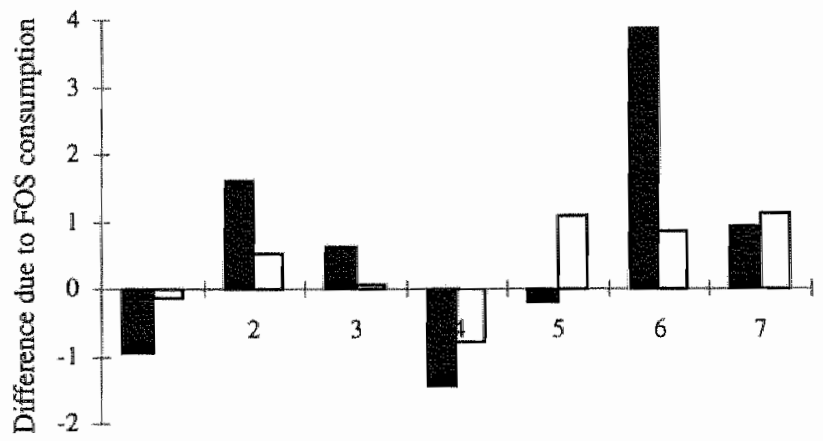

Subjects

\section{Discussion}

Precise measurement of isotope ratios constitutes the most important fundamental requirement in regard to feasibility of stable isotope investigations in man and animals. This is especially true for $\mathrm{Mg}$ because of both the high body content and relatively high natural abundance of ${ }^{25} \mathrm{Mg}$ and ${ }^{26} \mathrm{Mg}$ [13]. ICP-MS, which can be used for $\mathrm{Mg}$ isotope detection in urine, offers high sensitivity, rapid throughput and simple sample preparation [12]. Using ICP-MS, in the present study an overall precision of $<1.0 \%$ was found, which corresponds to the precision reported by Schuette et al [13], using ICP-MS. With the oral dose of stable isotopes used by Cary et al [12] we were able to obtain sufficient enrichment values in 36-h urine samples of $>3 \mathrm{SD}$ above the basal ratios. 
At the start of the human experiment we thought to apply the dual stable isotope technique to measure $\mathrm{Mg}$ and $\mathrm{Ca}$ absorption. As $\mathrm{Ca}$ absorption does not reach completion until about $26 \mathrm{~h}$ after the oral dose [17], the stable isotopes were measured in urine collected over $36 \mathrm{~h}$ after isotope administration to be sure to include the colonic component of both $\mathrm{Mg}$ and $\mathrm{Ca}$ absorption. The large intestine may represent a major site of $\mathrm{Ca}$ and $\mathrm{Mg}$ absorption when acidification takes place [18]. Besides, the FOS-induced positive effect on $\mathrm{Mg}$ absorption seems to take place mainly in the large intestine [9]. Although total $\mathrm{Mg}$ absorption may have completed earlier than $36 \mathrm{~h}$, we decided to measure both minerals in a 36-h urine sample to be able to relate the excretion of the orally given ${ }^{44} \mathrm{Ca}$ to the excretion of the orally given ${ }^{25} \mathrm{Mg}$.

Although in the dual stable isotope technique it is assumed that the orally and intravenously administered stable isotopes are metabolized simultaneously, this may not be true for $\mathrm{Mg}$ metabolism. Because of the high renal regulation of $\mathrm{Mg}$ metabolism, an important part of the intravenously injected $\mathrm{Mg}$ isotope will be excreted immediately or very rapidly in urine, as a consequence of a small change in serum Mg [19]. Therefore, according to Coudray et al [19], stable Mg isotope enrichments should preferably be measured in biological samples taken $24 \mathrm{~h}$ after isotope administration. However, the rapid and immediate urinary excretion after intravenous administration could also be due to the quantity of $\mathrm{Mg}$ isotope injected, which was about twice the total plasma $\mathrm{Mg}$ of the rat [19]. In humans, absorption was calculated from enrichment values determined in urine between 10 and $28 \mathrm{~h} \mathrm{[12].}$ Until no validation studies on dual stable isotope techniques for $\mathrm{Mg}$ in man have been carried out, the best time to collect urine for determination of $\mathrm{Mg}$ absorption in man is still unclear. The best approximations of the correct value for fractional absorption of $\mathrm{Ca}$ however, were given when $\mathrm{Ca}$ absorption was calculated by the ratios found in 24-h urine collected directly after isotope administration [20, 21]. As we compared $\mathrm{Mg}$ absorption in both treatments within the same subject, the time of collection would not have changed the outcome of this human experiment.

The excretion of ${ }^{44} \mathrm{Ca}$ was significantly related to the excretion of ${ }^{25} \mathrm{Mg}$ in the present study and most boys revealed the same FOS-induced effect on the ${ }^{25} \mathrm{Mg}$ and ${ }^{44} \mathrm{Ca}$ 
excretion (see Figure 2). Therefore, a common mechanism of the positive effect of FOS on $\mathrm{Ca}$ and $\mathrm{Mg}$ metabolisms may exist. Both $\mathrm{Mg}$ and $\mathrm{Ca}$ move across the intestinal epithelium trans-cellularly and para-cellularly. A high rate of $\mathrm{Ca}$ absorption in the large intestine could trigger a feedback mechanism involving an inhibition of duodenal absorption, since there is a control of the digestive balance of $\mathrm{Ca}$ by endocrine factors $[22,23]$. The possibility of a negative feedback in response to a highly effective absorption in the large intestine seems less likely for $\mathrm{Mg}$ than for $\mathrm{Ca}$. Therefore, fermentable fibre may have a larger effect on the apparent digestive balance of $\mathrm{Mg}$ than on that of $\mathrm{Ca}$ [18]. In rats the effect of FOS on $\mathrm{Ca}$ and $\mathrm{Mg}$ retention was significantly positive but more marked for $\mathrm{Mg}$ [10]. In boys, in contrast, FOS tended to increase the excretion of the orally given ${ }^{25} \mathrm{Mg}$, while a significant increase of the excretion of the orally given ${ }^{44} \mathrm{Ca}$ and also true $\mathrm{Ca}$ absorption was found. In 9 adult men who consumed inulin, Coudray et al [16] also showed only a slight non-significant increase of apparent Mg absorption, while apparent $\mathrm{Ca}$ absorption significantly increased. It is possible that the number of subjects selected in both our study and the study of Coudray et al [16] may have been too small to reach statistical significance.

Since our study was performed only with an oral administration of a stable isotope and not by the application of a dual stable isotope technique (oral and intravenous administration), no final conclusion about the potential effect of FOS on $\mathrm{Mg}$ absorption can be drawn and further research into the role of FOS on $\mathrm{Mg}$ absorption in humans is recommended.

\section{Acknowledgment}

Sources of support: European Union and ORAFTI s.a., Tienen, Belgium.

\section{References}

1 Schaafsma G. Bioavailability of callcium and magnesium. Eur J Clin Nutr 1997;51:S13-S16.

2 Brink EJ Beynen AC. Nutrition and magnesium absorption: a review. Progr Food Nutr Sci $1992 ; 16: 125-162$.

3. Roberfroid M. Dietary fiber, inulin, and oligofructose: a review comparing their physiological effects. Crit Rev Food Sci Nutr 1993;33:103-148. 
4 Ohta A, Ohtsuki M, Baba S, Takizawa $T$, Adachi $T$ \& Kimura $S$. Effects of fructo-oligosaccharides on the absorption of iron, calcium and magnesium in iron-deficient anemic rats. J Nutr Sci Vitaminol 1995;41:281-291.

5 Baba S, Ohta A, Ohtsuki M, Takizawa T, Adachi T \& Hara H. Fructomoligosaccharides stimulate the absorption of magnesium from the hindgut in rats. Nutr Res 1996;16:657-666.

6. Scharrer E \& Lutz T. Effects of short chain fatty acids and $\mathrm{K}$ on absorption of $\mathrm{Mg}$ and other cations by the colon and caecum. Z Ernährungswiss 1990;29:162-168.

7 Scharrer $\mathbf{E} \&$ Lutz T. Relationship between volatile fatty acids and magnesium absorption in mono- and polygastric species. Magnes Res 1992;5:53-60.

8 Ohta A, Ohtuki $M$, Takizawa $T$, Inaba $H$, Adachi $T$ \& Kimura $S$. Effects of fructo-oligosaccharides on the absorption of magnesium and calcium by cecectomized rats. Int $J$ Vitam Nutr Res 1994;64:316-323.

9 Ohta A, Baba S, Ohtsuki M, Takizawa T, Adachi T \& Hara H. In vitro absorption of calcium carbonate and magnesium oxide from the large intestine rats. $J$ Nutr Sci Vitaminol 1997;43:35-46.

10 Delzenne N, Aertssens J, Verplaetse H, Roccaro M \& Roberfroid M. Effect of fermentable fructo-oligosaccharides on mineral, nitrogen and energy digestive balance in the rat. Life $\mathrm{Sci}$ 1995;57:1579-1587.

11 Schwartz $\mathbf{R}$. ${ }^{26} \mathrm{Mg}$ as a probe in research on the role of magnesium in nutrition and metabolism. Federation Proc 1982;41:2709-2713.

12 Cary EE, Wood RJ \& Schwartz R. Stable Mg isotopes as tracers using ICP-MS. J Micronutr Anal 1990;8:13-22.

13 Schuette S, Vereault D, Ting BT \& Janghorbani M. Accurate measurement of stable isotopes of magnesium in biological materials with inductiveiy coupled plasma mass spectrometry. Analyst $1988 ; 113: 1837-1842$.

14 De Bièvre P \& Taylor PDP. Table of isotopic compositions of the elements. Int J Mass Spectrom Ion Processes 1993;123:149-166.

15 Genstat 5 Committee. Genstat five release three reference manual. New York: Oxford University Press, 1994.

16 Coudray C, Bellanger J, Castiglia-Delavaud C, Vermorel V \& Rayssignuier Y. Effect of soluble or partly soluble dietary fibres supplementation on absorption and balance of calcium, magnesium, iron and zinc in healthy young men. Eur J Clin Nutr 1997;51:375-380.

17 Barger-Lux MJ, Heaney RP \& Recker RR. Time course of calcium absorption in humans: evidence for a colonic component. Calcif Tissue Int 1989;44:308-311.

18 Younes H, Demigné C \& Rémésy C. Acidic fermentation in the caecum increases absorption of calcium and magnesium in the large intestine of the rat. BrJ Nutr 1996;75:301-314.

19 Coudray C, Pepin D, Tressol JC, Bellanger J \& Rayssiguer Y. Sudy of magnesium bioavailability using stable isotopes and the inductively-coupled plasma spectrometry technique in the rat: single and double labelling approaches. Br J Nutr 1997;77:957-970.

20 Griessen M, Jung A, Cochet B, Bartholdi $P$, Gaspoz $I M$, Infante F, Donath A, Loizeau E \& Courvoisier B. A simple method for measurement of intestinal calcium absorption in humans by double-isotope technique. J Lab Clin Med 1985; 105:641-646.

21 Yergey AL, Abrams SA, Vieira NE, Aldroubi A, Marini J \& Sidbury JB. Determination of 
Chapter 9

fractional absorption of dietary calcium in humans. J Nutr 1994:124:674-682.

22 Nellans HN \& Goldsmith RS. Transepithelial calcium transport by rat cecum: high-efficiency absorptive site. Am J Physiol 1981;240:G424-G431.

23 Bronner $F$, Pansu $D$ \& Stein WD. An analysis of intestinal calcium transport across the rat intestine. Am I Physiol 1986;250:G561-G569. 


\section{0}

\section{General discussion and conclusions}

Adequacy of the diet to supply sufficient amounts of minerals and trace elements and to prevent deficiency of these nutrients cannot be evaluated from dietary intake alone. Physiological and dietary factors affect the degree of intestinal absorption so that for most elements only a fraction of dietary intake is absorbed and utilized for body functions [1]. It appears that absorption is an important aspect of mineral and trace element nutrition. Absorption can be measured by the classical balance technique, i.e. the difference between intake and faecal excretion over a specified period of time. However, such a measurement does not take into account endogenous faecal losses of the element under study and thus only measures apparent (net) absorption. To measure true absorption an isotopic label of the exogenous element is required. Radioactive isotopes can be used for this purpose, but radiation limits their use in human experiments. Stable isotopes offer a good alternative.

Dual stable isotope techniques can be used to measure true intestinal absorption of essential elements such as $\mathrm{Ca}, \mathrm{Mg}$ and $\mathrm{Fe}$ in man. In these techniques, one stable isotope is given intravenously and another one orally. While for $\mathrm{Ca}$ or $\mathrm{Mg}$, absorption can be calculated from excretion of the two isotopes of either element in urine, the incorporation of both $\mathrm{Fe}$ isotopes into erythrocyte $\mathrm{Hb}$ is an established method of measuring Fe absorption. However, the amount of stable Fe isotopes needed to detect a significant enrichment of $\mathrm{Fe}$ isotopes in erythrocytes is rather large. Stable isotopes are expensive and, moreover, the amount of isotopes administered should not interfere with maintenance of physiological conditions during absorption tests. Therefore, our first aim was to develop a new method to measure Fe absorption with a minimum use of stable isotopes.

Currently, there is increasing interest in food ingredients with specific health benefits. 
Before these ingredients can be considered favourable to human health, their safety and efficacy have to be assessed, including their influence on mineral and trace element absorption. This brings us to the second aim of the studies described in this thesis, namely to apply the dual stable isotope technique to study the influence of several potential functional food ingredients on mineral and trace element absorption. The ingredients studied were bovine lactoferrin (Lf), non-digestible oligosaccharides (NDO) and lactulose, as these ingredients have been shown to exert a positive effect on the absorption of $\mathrm{Fe}, \mathrm{Ca}$ and/or $\mathrm{Mg}$ in animal experiments. Although our intention was to apply the newly developed method which requires less stable isotopes to measure Fe absorption, this method had not been validated at the time we had the opportunity to study the effect of lactoferrin and NDO on bioavailability (absorption) of Fe. Therefore, for the time being, we decided to apply the traditional method, in which the administration of the high dose of stable isotopes was spread over several days to avoid interference with physiological conditions.

In this chapter, the two aims are discussed in relation to physiological and methodological aspects. Special attention is paid to the methodology as the application of dual stable isotope technique was an important aspect of the work presented.

\section{First aim: a new method}

As described in Chapter 3, after the intravenous administration of the ${ }^{58} \mathrm{Fe}$ dose, we achieved a much higher enrichment of the ${ }^{58} \mathrm{Fe} /{ }^{756} \mathrm{Fe}$ ratio in reticulocyte-rich cell fractions than in whole-blood erythrocytes. In contrast, no such enrichment in the ${ }^{57} \mathrm{Fe} /{ }^{56} \mathrm{Fe}$ ratio was found in reticulocyte-rich cell fractions after the oral administration of the ${ }^{57} \mathrm{Fe}$ dose, which indicated a very low Fe absorption. Based on results of rat experiments $[2,3]$, we attributed this low absorption to the order in which the stable isotopes were given, i.e. the oral dose after intravenous administration. The small intravenous dose may have been sensed by the intestinal epithelial cells via basolateral endocytosis of the transferrin forms [4]. Consequently, absorption of the orally given isotope could have been inhibited. Therefore, it was not surprising that in the second study, described in Chapter 4, a significant enrichment 
of both the ${ }^{57} \mathrm{Fe} /{ }^{56} \mathrm{Fe}$ and the ${ }^{58} \mathrm{Fe} /{ }^{56} \mathrm{Fe}$ ratio was found in reticulocyte-rich cell fractions when the order of isotope administration was reversed. From these isotope enrichments, Fe absorption was validly estimated. Moreover, it appeared that the enrichment was three times higher in reticulocyte-rich cell fractions than in whole blood. Therefore, with this newly developed method the amount of stable isotopes required can be reduced to a more physiological dose of stable isotopes (one-third of the usual dose) by using reticulocyte-rich cell fractions. An additional advantage is that this method can be applied to measure $\mathrm{Fe}$ absorption in people who usually absorb very small amounts of Fe, like men.

Next to these advantages, this new method has the disadvantage of being more labour-intensive because of the density separation required to isolate reticulocyte-rich cell fractions. Several blood samples (two to six times $4 \mathrm{ml}$ ) must be processed to obtain an isolated reticulocyte-rich cell fraction with a sufficient amount of Fe for measurement by inductively coupled plasma mass spectrometry (ICP-MS). The amount of blood that is to be processed may depend on the subject's sex because a higher reticulocyte count is found in men than in women [5]. In addition, different operational conditions under which the density separation of erythroid cells is carried out, such as temperature, reagents, $\mathrm{pH}$, osmolarity and density [6], may determine the quantity of blood that should be processed for ICP-MS analysis.

Besides the fact that the new method is more labour-intensive, the relatively large amount of blood to be separated makes the new method not suitable for infants. However, because of their low body mass and hence small blood volume of $81 \mathrm{ml}$ per $\mathrm{kg}$ of body weight [7], a relatively low dose of stable isotopes is sufficient for measurable isotope enrichment of all erythrocytes in infants. This makes the traditional method, in which Fe absorption is measured by means of Fe isotope incorporation into erythrocytes in a small blood sample, more feasible in infants.

\section{Second aim: potential functional food ingredients and element absorption}

We investigated the efficacy and safety of several potential food ingredients with respect to mineral and trace element absorption. Before any conclusions can be 
drawn, the results found in the studies described in earlier chapters, are discussed with respect to factors related to methodology (design, materials and methods) and physiology (type of subjects, duration of intervention).

\section{Statistical power of the study design}

In the study on bovine lactoferrin in women with low iron stores (Chapter 5), a rather high within-subject variability of $\mathrm{Fe}$ absorption was found. Fe absorption averaged $18 \%$ with a SD of the pooled mean of $9.1 \%$. This high variability reduces the statistical power needed to detect treatment differences with the small sample size used $(\mathrm{n}=8)$. The least difference in absorption between treatments we would have been able to detect is $7.7 \%(\mathrm{P}=0.05$, one-sided $)$ or $9.5 \%(\mathrm{P}=0.05$, two-sided $)$. Turnlund et al [8], who applied the faecal monitoring technique with all its inaccuracies (see Chapter 2), measured in healthy women a mean Fe absorption of ca. $8.5 \%$ with a SD of the pooled mean of $1.04 \%$. It is remarkable that the variances between the studies differ that much. Within-subject variability seems to increase at higher absorption rates. This notion is underscored by the study of Hunt et al [9], who measured in women with low Fe stores a mean apparent Fe absorption of $5.6 \mathrm{mg} / \mathrm{d}$ (ca. 32\%) with a pooled SD of $2.7 \mathrm{mg} / \mathrm{d}$ (ca. $16 \%$ ).

Other causes of the differences between the pooled SDs may include the diet administered on the days before isotope administration [10, 11], which may influence variance of Fe absorption. In contrast to Turnlund et al [8], we did not control dietary Fe intake prior to the isotope test. The effect of Fe intake on the previous day is dependent on the maturity of the affected mucosal cells and as well as mucosal cell turnover [10]. In man, the entire lining of the small intestine is replaced within 5 to 6 d [12]. Therefore, we would have eliminated, at least partially, bias in the results of Fe absorption with a strict dietary control over at least $6 \mathrm{~d}$ prior to the Fe absorption test.

Thus, we may have been able to detect a difference in Fe absorption of at least $7.7 \%$ in the study on Lf (Chapter 5). A smaller difference than $7.7 \%$ may be of physiological importance and we cannot exclude the possibility that we have missed smaller treatment effects. Neverthelless, average absorption rates were almost 
identical for each treatment and no dose-effect relation was found. In our opinion, this makes a positive effect of bovine Lf on Fe absorption in man rather unlikely.

The small sample size used and hence the limited power of the study on the effect of fructo-oligosaccharides (FOS) on $\mathrm{Mg}$ metabolism (Chapter 9) should also be mentioned. Because of problems with the quantity of the $\mathrm{Mg}$ isotopes delivered to the institute, only 7 boys could participate in this study. A pooled SD of 1.28 of the proportion of orally administered ${ }^{25} \mathrm{Mg}$ excreted was found. Therefore, we would have been able to detect a difference in excretion of administered ${ }^{25} \mathrm{Mg}$ of at least $1.22 \%$ (one-sided, $\mathrm{P}<0.05$ ) or $1.49 \%$ (two-sided, $\mathrm{P}<0.05$ ). However, FOS increased urinary excretion from $3.5 \%$ to $4.1 \%(\mathrm{P}=0.348$, two-sided $)$. Unfortunately, insufficient data for power analyses are reported by Coudray et al [13], who found a tendency towards increased apparent $\mathrm{Mg}$ absorption in a cross-over design with 9 subjects. As the number of subjects in both studies was low, we cannot exclude the possibility of a type II error, for example not accepting the alternative hypothesis while it is true (e.g. FOS increases Mg absorption).

\section{Carrier dose}

Seven adolescent boys (Chapters 7 and 9), were simultaneously given orally ${ }^{25} \mathrm{Mg}$ and ${ }^{44} \mathrm{Ca}$ together with a standard breakfast, resulting in a total intake of ca. $215 \mathrm{mg}$ $\mathrm{Ca}$ and $85 \mathrm{mg} \mathrm{Mg}$. Although it has been rejected that a high $\mathrm{Ca}$ intake decreases absorption and retention of $\mathrm{Mg}$ or conversely [14-16], competition between $\mathrm{Ca}$ and $\mathrm{Mg}$ for the enhancing effect of FOS on absorption may have occurred. For example, if short-chain fatty acids (SCFA) produced through fermentation of the NDO indeed improve $\mathrm{Mg}$ absorption via $\mathrm{Mg}^{2+} / \mathrm{H}^{+}$exchange, luminal $\mathrm{Mg}{ }^{2+}$ may have been in competition with luminal $\mathrm{Ca}^{2+}$ for exchange with intracellular $2 \mathrm{H}^{+}$. A competition between $\mathrm{Ca}$ and $\mathrm{Mg}$ for part of the enhancing effect of NDO may explain the lack of significance of the stimulating effect of NDO on Mg metabolism, as described in Chapter 9. This may also explain the lack of significance of the increase in apparent $\mathrm{Mg}$ absorption found by Coudray et al [13], who used a diet containing ca. $860 \mathrm{mg}$ $\mathrm{Ca}$ and $310 \mathrm{mg} \mathrm{Mg}$. Dietary intake of $\mathrm{Ca}$ and $\mathrm{Mg}$ by Dutch men aged 19-22 averages 
$1040 \mathrm{mg} \mathrm{Ca}$ and $370 \mathrm{mg} \mathrm{Mg} \mathrm{[17].} \mathrm{Therefore,} \mathrm{if} \mathrm{competition} \mathrm{between} \mathrm{Ca}$ and $\mathrm{Mg}$ occurred for the effect of NDO through SCFA, one may raise questions about the significance of $\mathrm{NDO}$ for $\mathrm{Mg}$ absorption in a typical western diet rich in $\mathrm{Ca}$.

\section{Dose of study substance}

The dose of NDO given by Coudray et all [13] to adlult men was $40 \mathrm{~g} / \mathrm{d}$. We gave a more feasible dose of $15 \mathrm{~g} / \mathrm{d}$ to adult men (Chapter 6) and boys (Chapter 7). While Coudray et al [13] found an increase in Ca absorption in adult men, we did not found such an increase (Chapter 6). However, $15 \mathrm{~g} / \mathrm{d}$ of NDO appeared to be sufficient to increase $\mathrm{Ca}$ absorption in boys (Chapter 7 ). There might exists a relation between the dose of $\mathrm{NDO}$ and the increase in $\mathrm{Ca}$ absorption, like we found for lactulose in postmenopausal women (Chapter 8 ) and rats [18]. This would mean that the threshold dose of NDO required to increase Ca absorption in adult men is higher than $15 \mathrm{~g} / \mathrm{d}$. In contrast, $15 \mathrm{~g} / \mathrm{d}$ of FOS or $10 \mathrm{~g} / \mathrm{d}$ of lactulose was sufficient to produce a significant effect in boys or postmenopausal women, respectively.

A dose of NDO of $40 \mathrm{~g} / \mathrm{d}$ [13] in adults and $15 \mathrm{~g} / \mathrm{d}$ in boys (Chapter 9) was mot sufficient to stimulate $\mathrm{Mg}$ metabolism significantly. This indicates that in adult men no relation exists between $\mathrm{NDO}$ dose and $\mathrm{Mg}$ absorption, at least for tolerable dosages of NDO.

\section{Selection of the dose of stable isotopes}

A major issue in the design of stable-isotope studies involves the selection of tracer doses which provide an optimum level of label readily measurable by ICP-MS. The precision of the analysis of each isotope is an important factor in the determination of the isotope dose required. This precision allows for calculation of the limit of detection. In general terms, the limit of detection may be described as the isotope ratio, determined with the ICP-MS, that is significantly different from the 'blank", 'background' or basal ratio. A reasonable definition of a limit of detection is an enrichment percentage of more than 3 times the coefficient of variation of the basal ratio [19]. The coefficient of the within-duplicate variation (CV) measured in the $\mathrm{Ca}$ 
absorption studies described in this thesis was $\leq 0.3 \%$ for the ${ }^{44} \mathrm{Ca} /{ }^{43} \mathrm{Ca}$ ratio and $\leq 0.8 \%$ for the ${ }^{48} \mathrm{Ca} /{ }^{43} \mathrm{Ca}$ ratio. The average enrichments were $\geq 4.1 \%$ for the ${ }^{4} \mathrm{Ca} /{ }^{4} \mathrm{Ca}$ ratio and $\geq 8.8 \%$ for the ${ }^{48} \mathrm{Ca} /{ }^{43} \mathrm{Ca}$ ratio. A percentage of enrichment much higher than 3 times the $\mathrm{CV}$ was also found for the ${ }^{25} \mathrm{Mg} /{ }^{24} \mathrm{Mg}$ ratio (Chapter 9). This indicates at least that the dose of stable $\mathrm{Ca}$ isotopes could have been reduced. Taken into account the limited number of small human experiments on $\mathrm{Mg}$ absorption with the measurement of stable isotopes in urine/plasma by ICP-MS [20,21], we think further research is needed before one can arrive at conclusions about reducing the required dose of $\mathrm{Mg}$ isotopes.

For the $\mathrm{Fe}$ isotope studies, calculation of the dose of stable $\mathrm{Fe}$ isotopes appeared to be more difficult. In the study described in Chapter 6, selection of the dose of stable isotopes was based on a $\mathrm{CV}$ of measured ratios of less than $1 \%$, an absorption of $6 \%$ (due to the addition of vitamin $\mathrm{C}$ ) and incorporation of absorbed Fe into erythrocytes of $80 \%$. We assumed a $37 \mathrm{mg}$ dose of ${ }^{57} \mathrm{Fe}$ given orally should enrich the basal isotope ratios in whole blood sufficiently to obtain a significant change in these ratios. However, most men appeared to absorb less than $6 \%$ and about half of all enrichment values of the ${ }^{57} \mathrm{Fe} /{ }^{36} \mathrm{Fe}$ ratio were less than 3 times the $\mathrm{CV}$. If we would have given a higher dose of ${ }^{57} \mathrm{Fe}$ orally, the barrier function of the intestine against $\mathrm{Fe}$ overload would likely have resulted in the same amount of ${ }^{57} \mathrm{Fe}$ absorbed, as a higher dose of isotope does not result in a higher enrichment when absorption is near zero. Woodhead et al [22] reported also isotope enrichment values lower than 3 times the $\mathrm{CV}$ and found similar $\mathrm{Fe}$ absorption percentages to those obtained with radioisotopes. In the Lf study (Chapter 5), some enrichment values of both the ${ }^{57} \mathrm{Fe} /{ }^{56} \mathrm{Fe}$ ratio and the ${ }^{58} \mathrm{Fe} /{ }^{56} \mathrm{Fe}$ ratio were below the calculated detection limit of $3 \mathrm{x}$ SD [19]. The low enrichment of the ${ }^{58} \mathrm{Fe} /{ }^{56} \mathrm{Fe}$ ratio was mainly due to the low $\mathrm{Fe}$ incorporation found in one endurance athlete, which amounted on average to $47 \%$ (range 29-69\%). With this subject excluded, mean recovery was $74 \%$. Although in male long distance runners with sufficient $\mathrm{Fe}$ stores a mean ${ }^{59} \mathrm{Fe}$ incorporation into erythrocytes of $80 \%$ (range 63-98\%) has been found [23], strenuous exercise or physical activity may affect $\mathrm{Fe}$ metabolism, even after short periods of mild fitness-type exercise [24]. Consequently, 
sports activities of the only athlete in the Lf study, which were of an irregular nature due to tiredness of this subject, may have affected Fe metabolism and hence Fe incorporation into erythrocytes.

It should be stressed that isotope enrichment values below the limit of detection may reflect natural situations. However, to select the dose of stable isotopes required for sufficient enrichment, one should always use the limit of detection to reduce the variance due to ICP-MS measurements.

If we would have used the new method (isolation of young erythroid cells) more individual enrichment values would have exceeded the detection limit. Consequently, the ICP-MS measurement would make up a smaller proportion of the total variance of $\mathrm{Fe}$ absorption and we would have been able to detect smaller changes in Fe absorption caused by NDO or Lf. However, compared to the within-subject variance, this reduction of the total variance of Fe absorption, would be relatively small.

\section{Measurement of absorption}

In the study of Coudray et al [13] and in all rat experiments published to date, the colonic component of $\mathrm{Ca}$ absorption was included because the balance or the faecal monitoring technique was used. Since Ellegård et al [25] have shown that, in ileostomy subjects, neither inulin nor FOS influence the absorption of $\mathrm{Ca}$ in the small intestine, it is likely that a positive effect of inulin on $\mathrm{Ca}$ balance as found by Coudray et al [13] originated predominantly in the colon. Therefore, compared to our first study (Chapter 6), in subsequent studies on the effect of non-digestible carbohydrates on Ca absorption (Chapters 7 and 8), urine collection after isotope administration was extended by $12 \mathrm{~h}$ to $36 \mathrm{~h}$, which was assumed to include the measurement of $\mathrm{Ca}$ isotope originating from colonic absorption. Although urine collected over $24 \mathrm{~h}$ after isotope administration has been shown to give a valid approximation of $\mathrm{Ca}$ absorption $[26,27]$, the validity of a $36-\mathrm{h}$ urine sample for the measurement of Ca absorption by the dual stable isotope technique has not yet been assessed. However, we have no reasons to believe that $\mathrm{Ca}$ absorption based on a $36-\mathrm{h}$ urine collection is not valid because Griessen et al [26] have shown that a different duration of collecting urine over at least $8 \mathrm{~h}$ to $30 \mathrm{~h}$ does not significantly affect $\mathrm{Ca}$ 
absorption estimates. The method seems to be rather robust as urine collected over 24 $\mathrm{h}$ or $36 \mathrm{~h}$ after isotope administration, represents the ratio of the areas under the plasma disappearance curves for the two stable isotopes [27] and is therefore less sensitive to differences in time of entrance of the stable isotopes into the blood. compartment.

However, if colonic absorption contributes to a large extent to total $\mathrm{Ca}$ absorption, more $\mathrm{Ca}$ absorbed in the colon will arrive in the blood stream later than the intravenously injected $\mathrm{Ca}$. Diurnal variation of bone mineral turnover and urinary $\mathrm{Ca}$ excretion $[28,29]$ may then lead to a different metabolism of the absorbed Ca from the colon compared to the intravenously given isotope, which enters the blood stream much earlier. Such a bias would, however, not invalidate the results described in Chapters 7 and 8 , since it occurred in both treatments. To what extent this diurnal variation in $\mathrm{Ca}$ metabolism affects the estimation of $\mathrm{Ca}$ absorption may be worth being further studied.

Although most of the $\mathrm{Mg}$ absorption takes place within the first 12 hours after $\mathrm{Mg}$ ingestion [30], we measured the $\mathrm{Mg}$ isotope excretion in 36-h urine. By extending the urine collection over 36 hours we may have diluted the effect of FOS on $\mathrm{Mg}$ absorption (Chapter 9). However, in this way we were able to compare the effect of FOS on the excretion of both the orally given ${ }^{44} \mathrm{Ca}$ and ${ }^{25} \mathrm{Mg}$, as we expected the FOS-induced effect on both $\mathrm{Mg}$ and $\mathrm{Ca}$ absorption to follow the same pattern as that seen in animals.

Information about $\mathrm{Mg}$ absorption and metabolism is scanty. This lack of data is largely due to limitations in the use of radioisotopes, for example too short a half-life of available $\mathrm{Mg}$ isotopes, and methodological problems inherent to balance studies, for example imprecision due to problems in separating faecal contents according to the corresponding dietary period [1]. Coudray et al [13] applied the chemical balance technique to study the effect of inulin on apparent $\mathrm{Mg}$ absorption (intake-faeces). Because no isotopes were used, no distinction in the faecal samples could be made between unabsorbed elements of dietary origin and the same elements excreted endogenously [1]. Using stable isotopes, true $\mathrm{Mg}$ absorption can be estimated by 
performing isotope measurements in plasma or urine when ${ }^{26} \mathrm{Mg}$ is administered orally and ${ }^{28} \mathrm{Mg}$ is injected intravenously [31]. In rats, a dual and single labelling technique with stable isotopes was compared with the metabolic balance technique in estimating $\mathrm{Mg}$ bioavailability. The true $\mathrm{Mg}$ absorption values measured by the dual stable isotope technique were very similar when calculated from blood or urine data, but lower than those obtained with the balance technique. The dual stable isotope technique was considered to be more convenient for comparative studies on $\mathrm{Mg}$ bioavailability [32]. As this technique has also been applied in human studies [20, 21], we decided to use this method to investigate the effect of FOS on Mg absorption. Unfortunately, due to problems with the quality and quantity of $\mathrm{Mg}$ isotopes delivered to our institute, only 7 subjects could be administered orally ${ }^{25} \mathrm{Mg}$. When only one stable isotope is administered orally, $\mathrm{Mg}$ absorption has often been calculated from the excretion of this unabsorbed isotope into faeces $[31,33,34]$. However, at the time of the experiment we only had assessed the validity of the ICPMS measurements of stable Mg isotopes in urine, not in faeces. Moreover, the faecal monitoring technique is very labourious, both for the subjects and for the investigator, and we wished to be able to compare the $\mathrm{Mg}$ data with the Ca data as described in Chapter 9. For these reasons, we decided to investigate the effect of FOS on $\mathrm{Mg}$ absorption by measuring urinary excretion of this orally administered $\mathrm{Mg}$ isotope. Assuming that the excretion of the absorbed fraction does not change, a change in urinary excretion of the orally administered $\mathrm{Mg}$ isotopes should indicate a change in absorption due to FOS. In infants, a similar fraction of the absorbed ${ }^{25} \mathrm{Mg}$ was excreted into urine, although absolute isotope absorption increased due to a higher ${ }^{25} \mathrm{Mg}$ dose [34]. Also in adolescent boys, a similar fraction of absorbed ${ }^{44} \mathrm{Ca}$ was excreted into urine, although absorption changed (Chapter 7). Therefore, in subjects who may retain more minerals for tissue growth, a proportional change in excretion of the oral dose of ${ }^{25} \mathrm{Mg}$ due to FOS may indeed indicate an FOS-induced change in $\mathrm{Mg}$ absorption.

Type of subjects

We studied the effect of NDO on Fe absorption in apparently healthy men and the 
effect of Lf on Fe absorption in women with low Fe stores. It appears from studies on the bioavailability of $\mathrm{Fe}$ that the effects of dietary variables that influence $\mathrm{Fe}$ absorption are particularly clear under conditions of a low Fe status of the body [35]. Since man is unable to excrete significant quantities of endogenous $\mathrm{Fe}$ and since accumulation of $\mathrm{Fe}$ is toxic, it is essential that the uptake of $\mathrm{Fe}$ is adequately controlled by the intestinal mucosa [36]. The powerful control of Fe absorption implies that $\mathrm{Fe}$ overload cannot develop under normal conditions, unless there is a genetic predisposition, even with diets that are rich in Fe or contain highly bioavailable Fe in significant amounts [35]. Therefore, the phenomenon of the barrier against $\mathrm{Fe}$ absorption could explain why we, as described in Chapter 6, did not find an effect of $15 \mathrm{~g} / \mathrm{d}$ of NDO on non-haem Fe absorption in healthy men, an observation also reported by Coudray et al [13] for a diet with $40 \mathrm{~g} / \mathrm{d}$ of inulin. In iron-deficient anaemic rats $5 \%$ FOS stimulated apparent Fe absorption [37], whereas $10 \%$ FOS or inulin also increased Fe absorption in growing rats with saturated $\mathrm{Fe}$ stores [38]. Although the latter mentioned rats were not iron-deficient [38], their Fe absorption may also be more susceptible to bioavailability because of growth. A negative association between growth velocity and serum ferritin values has been found and explained by the need for Fe during growth of lean tissue [39]. Growth and development put high demands on dietary supply of nutrients. In young rats, Fe absorption is high and decreases markedly with age [40]. Because we measured the effect of NDO on Fe absorption in healthy adult men, we cannot exclude the possibility that NDO increase Fe absorption in man when Fe stores are low or Fe requirement is high. However, we may conclude that in adult men with saturated Fe stores, NDO do not affect Fe absorption unfavourably. This is relevant in view of the safety of these compounds.

Cat absorption is influenced by exogenous and endogenous factors. Endogenous factors related to the type of subjects are, for example, metabolic needs (growth or $\mathrm{Ca}$ deficiency increases $\mathrm{Ca}$ absorption), ageing (decreased $\mathrm{Ca}$ absorption) [41] and, concomitantly, the efficacy of the controlling mechanism of $\mathrm{Ca}$ absorption. Growth, and thus a higher $\mathrm{Ca}$ requirement, may explain for the fact that NDO stimulated $\mathrm{Ca}$ 
absorption in rapidly growing adolescents (Chapter 7), while no such effect was found in adult men (Chapter 6). This is supported by the findings of Kashimura et al [42] which indicate that the increase of mineral retention induced by NDO feeding is seen when rats are very young. Although Coudray et al [13], did find a positive effect of inulin on $\mathrm{Ca}$ absorption in adult men, this may also be due to the much higher dose of NDO given (see Dose of study substance).

Under steady-state conditions of zero Ca balance, like in adult men, it is possible that $15 \mathrm{~g} / \mathrm{d}$ of NDO is too small a dose to increase Ca absorption detectably. Under such conditions elevated passive $\mathrm{Ca}$ absorption may be followed by decreased active $\mathrm{Ca}$ absorption, since the digestive ballance of $\mathrm{Ca}$ is controlled by endocrine factors [43, 44]. In adolescent girls, it appears that such a feedback mechanism of $\mathrm{Ca}$ absorption resulting from a higher $\mathrm{Ca}$ intake is operating around a higher cut-off point than in adult women [45]. In middle-aged women, a highly significant fall in absorption efficiency with age is seen as well as a one-time decrease at the time of menopausal estrogen loss [46]. Some studies, but not all, have reported decreased levels of serum $1,25(\mathrm{OH})_{2} \mathrm{D}$ with age [47]. The observation of an age-related decrease in $\mathrm{Ca}$ absorption and serum $1,25(\mathrm{OH})_{2} \mathrm{D}$ levels points to the possibility of a defect in the active component of $\mathrm{Ca}$ absorption [48]. Because adolescents and postmenopausal women were selected as subjects in our studies (Chapters 7 and 8 ), the negative feedback of active $\mathrm{Ca}$ absorption to FOS or lactulose-induced increases of passive $\mathrm{Ca}$ transport may have occurred to a lesser extent.

\section{Duration intervention}

In Chapter 5, we discuss the possibility that, because of species specificity or proteolytic breakdown with a resulting loss of functionality, bovine Lf was not effective in stimulating $\mathrm{Fe}$ absorption in man. One might argue that the duration of the treatment with Lf may explain the discrepancy between our human study and the animal studies. In our human study bovine Lf and ${ }^{57} \mathrm{Fe}$ were given only twice during breakfast, on two successive days. Although we cannot exclude the possibility that a longer period of adaptation to bovine Lf would have produced a different outcome in our human study, this is not supported by the proposed mechanisms by which Lf 
directly seems to stimulate Fe absorption, i.e. solubilization of ferric Fe [49] and/or via binding of Fe-Lf complex to Lf receptors $[50,51]$. Thus, duration of Fe supplementation in the presence of Lf may not have contributed to the difference in outcome between the animal experiment and our human study.

A longer duration of the adaptation period to FOS should also be discussed in relation to the non-significance of the $\mathrm{Mg}$ results (Chapter 9). In adolescent boys, 15 $\mathrm{g} / \mathrm{d}$ of FOS tended to increase the excretion of orally administered ${ }^{25} \mathrm{Mg}$ and thus probably also its concomitant $\mathrm{Mg}$ absorption. Also in adult men, Coudray et al [13] found during inulin consumption, next to an improved $\mathrm{Ca}$ balance, a non-significant but slightly more positive $\mathrm{Mg}$ balance. In their study, the chemical balance technique was applied with faeces being collected between Day 20 and Day 28 of each treatment period. The authors suggest that the effect of inulin on $\mathrm{Mg}$ absorption could be slower than that on $\mathrm{Ca}$ absorption and may require a longer adaptation period than $20 \mathrm{~d}$ [13]. However, this is not supported by the fact that in rats an increase in apparent absorption of both $\mathrm{Mg}$ and $\mathrm{Ca}$ is found already after $7 \mathrm{~d}$ of FOS-feeding [52]. Moreover, some of the proposed mechanisms of NDO-induced enhancement of $\mathrm{Mg}$ absorption, such as $\mathrm{Mg}$ solubilization [53,54] and possible specific effects of SCFA [55], are more direct effects, which do not require an adaptation period longer than $20 \mathrm{~d}$.

\section{Conclusions}

Referring to the aims mentioned in the introductory chapter of this thesis, the following conclusions are drawn:

- By measuring isotope enrichment in isolated young erythroid cells, Fe absorption can be determined with a smaller amount of administered stable isotopes than by measuring isotope enrichment in whole blood (the traditional method). The former procedure saves money and avoids interference with maintenance of physiological conditions during absorption tests.

- Our results did not provide evidence for a positive effect of bovine lactoferrin on Fe absorption in persons with low Fe stores. 
- Our results showed that the bioavailability of $\mathrm{Ca}$ can be increased in adolescents by a feasible dose of $15 / \mathrm{d}$ of fructo-oligosaccharides. Besides, intake of nondigestible oligosaccharides, such as inulin, fructo-oligosaccharides and galactooligosaccharides, does not adversely affect $\mathrm{Fe}, \mathrm{Ca}$ or $\mathrm{Mg}$ absorption.

- In postmenopausal women, a feasible amount of $10 \mathrm{~g} / \mathrm{d}$ of lactulose stimulates $\mathrm{Ca}$ absorption.

\section{References}

1 Sandström B, Fairweather-Tait S, Hurrell R \& Van Dokkum W. Methods for studying mineral and trace element absorption in humans using stable isotopes. Nutr Res Rev 1993;6:71-95.

2 Kreuzer M \& Kirchgessner M. Endogenous iron excretion. A quantitative means to control iron metabolism? Biol Trace Elem Res $1991 ; 29: 77-92$.

3 Gruden $\mathbf{N}$. The effect of parenteral iron administration upon iron absorption in young rats. Nutr Rep Intern 1988;38:955-960.

4 Nuñez MT, Tapia V \& Arredondo M. Intestinal epithelia (Caco-2) cells acquire iron through the basolateral endocytosis of transferrin. J Nutr 1996;126:2151-2158.

5 Tarallo P, Humbert JC, Fournier B, Mahassen P \& Henny J. Reticulocytes: reference limits. Clin Lab Haematol 1996;18:13-14.

6 Salvo G, Caprari P, Samoggia P, Mariani G \& Salvati AM. Human erythrocyte separation according to age on a discontinuous "Percoll" density gradient. Clin Chim Acta 1982;122:293-300.

7 Geigy Scientific Tables. 8th edit. Basle: Ciba-Geigy, 1981.

8 Turnlund JR, Smith RG, Kretsch MJ, Keyes WR \& Shah AG. Milk's effect on the bioavailability of iron from cereal-based diets in young women by use of in vitro and in vivo methods. Am J Clin Nutr 1990;52:373-378.

9 Hunt JR, Gallagher SK \& Johnson LK. Effect of ascorbic acid on apparent iron absorption by women with low iron stores. Am J Clin Nutr 1994;59:1381-1385.

10 Fairweather-Tait SJ \& Minski MJ. Studies on iron availability in man, using stable isotope techniques. Br J Nutr 1986;55:279-285.

11 Mason PM, Judd PA, Fairweather-Tait SJ, Eagles I \& Minski MJ. The effect of moderately increased intakes of complex carbohydrates (cereals, vegetables and fruit) for 12 weeks on iron and zinc metabolism. Br I Nutr 1990;63:597-611.

12 Schauf CL, Moffett DF \& Moffett SB. Gastrointestinal organization, motility and secretion. In: Human Physiology: Foundarion \& Frontiers. Allen D, ed. St. Louis: Times Mirror/Mosby College Publishing, 1990:532-561.

13. Coudray C, Bellanger J, Castiglia-Delavaud C, Vermorel V \& Rayssignuier Y. Effect of soluble or partly soluble dietary fibres supplementation on absorption and balance of calcium, magnesium, iron and zinc in healthy young men. Eur J Clin Nutr 1997;51:375-380.

14 Spencer H, Fuller H, Norris C \& Williams D. Effect of magnesium on the intestinal absorption of calcium in man. $J$ Am Coll Nutr 1994;13:485-492. 
15 Andon MB, llich JZ, Tzagournis \& Matkovic V. Magnesium balance in adolescent females consuming a low- or high-calcium diet. Am J Clin Nutr 1996;63:950-953.

16 Sojka J, Wastney M, Abrams S, Lewis SF, Martin B, Weaver C \& Peacock M. Magnesium kinetics in adolescent girls determined using stable isotopes: effects of high and low calcium intake. Am J Physiol 1997;273:r710-r715.

17 Van Dokkum W, Schneijder P, Van Erp-Baart AMJ, Van Aken AMMAM, Muijs T \& Van Schaik F. Part 2 Minerals, trace elements and vitamins Report number V94.173. In: Dietary intake in the Netherlands. Input from TNO Total Diet Study 1988-1989. 2nd edit. Zeist: 1994.

18 Brommage R, Binacua C, Antille S \& Carrie AL. Intestinal calcium absorption in rats is stimulated by dietary lactulose and other resistant sugars. J Nutr 1993;123:2186-2194.

19 Miller JC \& Miller JN. Errors in instrumental analysis;regression and correlation. In: Statistics for analytical chemistry. 2nd edit. Miller JC, Miller JN, eds. West Sussex: Ellis Horwood Limited, 1988:101-135.

20 Cary EE, Wood RJ \& Schwartz R. Stable Mg isotopes as tracers using ICP-MS. J Micronutr Anal 1990;8:13-22.

21 Benech $\mathbf{H}$ \& Grognet JM. Recent data on the evaluation of magnesium bioavailability in humans. Magnes Res 1995;8:277-284.

22 Woodhead JC, Drulis JM, Rogers RR, Ziegler EE, Stumbo PI, Janghorbani M, Ting BT \& Fomon SJ. Use of the stable isotope, 58Fe, for determining availability of nonheme iron in meals. Pediatr Res 1988:23:495-499.

23 Nachtigall D, Nielsen P, Fisher, Engelhardt R \& Gabbe EE. Iron deficiency in distance runners a reinvaestigation using 59Fe-labelling and non-invasive liver iron quantification. Int J Sport Med 1996:17:473-479.

24 Weaver CM \& Rajaram S. Exercise and iron status. J Nutr 1992;122:782-787.

25 Ellegård L, Andersson H \& Bosaeus I. Inulin and oligo-fructose do not influence the absorption of cholesterol, or the excretion of cholesterol, $\mathrm{Ca}, \mathrm{Mg}, \mathrm{Zn}, \mathrm{Fe}$, or bile acids but increases energy excretion in ileostomy subjects. Eur J Clin Nutr 1997;51:1-5.

26 Griessen M, Jung A, Cochet B, Bartholdi P, Gaspoz JM, Infante F, Donath A, Loizeau E \& Courvoisier B. A simple method for measurement of intestinal calcium absorption in humans by double-isotope technique. J Lab Clin Med 1985; 105:641-646.

27 Yergey AL, Abrams SA, Vieira NE, Aldroubi A, Marini J \& Sidbury JB. Determination of fractional absorption of dietary calcium in humans. J Nutr 1994;124:674-682.

28 Greenspan SL, Dresner-Pollak R, Parker RA, London D \& Ferguson L. Diurnal variation of bone mineral turnover in elderly men and women. Calcif Tissue Int 1997;60:419-423.

29 El-Hajj Fuleihan G, Klerman EB, Brown EN, Choe Y, Brown EM \& Czeisler CA. The parathyroid hormone circadian rhythm is truly endogenous- a clinical research center study. $J$ Clin Endocrinol Metab 1997;82:281-286.

30 Graham LA, Caesar JJ \& Burgen ASV. Gastrointestinal absorption and excretion of $28 \mathrm{Mg}$ in man. Metab 1960;9:646-659.

31 Schwartz R. $26 \mathrm{Mg}$ as a probe in research on the role of magnesium in nutrition and metabolism. Federation Proc 1982;41:2709-2713. 
32 Coudray C, Pepin D, Tressol JC, Bellanger J \& Rayssiguer Y. Study of magnesium bioavailability using stable isotopes and the inductively-coupled plasma spectrometry technique in the rat: single and double labelling approaches. Br J Nutr 1997;77:957-970.

33 Schuette $\mathrm{SA}$, Janghorbani $\mathrm{M}$, Young VR \& Weaver $\mathrm{CM}$. Dysporium as a non-absorbable marker for studies of mineral absorption with stable isotope tracers in human subjects. $J$ Am Coll Nutr 1993;12:307-315.

34 Schuette SA, Ziegler E., Nelson SE \& Janghorbani M. Feasibility of using the stable isotope $25 \mathrm{Mg}$ to study Mg metabolism in infants. Pediatr Res 1990;27:36-40.

35 Frultén L, Gramatkovski E. Gleerup A \& Hallberg L. Iron absorption from the whole diet. Relation to meal composition, iron requirements and iron stores. Eur J Clin Nutr 1995;49:794-808.

36 Ward R. Iron overload and toxicity. In: Iron. Nutritional and physiological significance. British Nutrition Foundation, ed. London: Chapman \& Hall, 1995:50-53.

37 Ohta A, Ohtsuki M, Baba S, Takizawa $T$, Adlachi $T$ \& Kimura S. Effects of fructo-oligosaccharides on the absorption of iron, calcium and magnesium in iron-deficient anemic rats. J Nutr Sci Vitaminol 1995;41:281-291.

38 Delzenne N, Aertssens J, Verplaetse H, Roccaro M \& Roberfroid M. Effect of fermentable fructo-oligosaccharides on mineral, nitrogen and energy digestive balance in the rat. Life Sci 1995;57:1579-1587.

39 Michaelsen KF. A longitudinal study of iron status in healthy Danish infants: effects of early iron status, growth velocity and dietary factors. Acta Paediatr 1995;84:1035-1044.

40 Naylor GPL \& Harrison JD. Gastro-intestinal iron and cobalt absorption and iron status in young rats and guinea pigs. Hum Exp Toxicol 1995;14:949-954.

41 Levenson DI \& Brockman RS. A review of calcium preparation. Nutr Res 1994;52:221-232.

42 Kashimura J, Kimura $M$ \& Itokawa $Y$. The effects of isomaltulose, isomalt, and isomaltulose-based oligomers on mineral absorption and retention. Biol Trace Elem Res 1996:54:239-250.

43 Nellans HN \& Goldsmith RS. Transepithelial calcium transport by rat cecum: high-efficiency absorptive site. Am J Physiol 1981;240:G424-G431.

44 Bronner F, Pansu D \& Stein WD. An analysis of intestinal calcium transport across the rat intestine. Am J Physiol 1986;250:G561-G569.

45 O'Brien KO, Abrams SA, Liang LK, Ellis KJ \& Gagel RF. Increased efficiency of calcium absorption during short periods of inadequate calcium intake in girls. Am I Clin Nutr 1996:63:579-583.

46 Heaney RP, Recker RR, Stegman MR \& Moy AJ. Calcium absorption in women: relationships to calcium intake, estrogen status, and age. J Bone Miner Res 1989:4:469-475.

47 Kinyamu HK, Gallagher JC, Prahl JM, Deluca HF, Petranick KM \& Lanspa SJ. Association between vitamin $D$ receptor, calcium absorption, and serum 1,25 dihydroxyvitamin $D$ in normal young and elderly women. $J$ Bone Miner Res 1997;12:922-928.

48 Weaver CM. Age related calcium requirements due to changes in absorption and utilization. $J$ Nutr 1994;124:1418S-1425S.

49 Kawakami IH, Dosako S \& Nakajima I. Effect of lactoferrin on iron solubility under neutral conditions. Biosci Biotech Biochem 1993;57:1376-1377. 
50 Spik G, Legrand D, Leveugle B, Mazurier J, Mikogami T, Montreuil J, Pierce A \& Rochard E. Binding properties of different lactoferrins to human lactotransferrin receptor. In: New perspectives in infant nutrition. Renner B, Sawatziki G, eds. New York: Thieme Medical Publishers Inc. 1993:78-83.

51 Mikogami T, Marianne T \& Spik G. Effect of intracellular iron depletion by picolinic acid on expression of the lactoferrin receptor in the human colon carcinoma cell subclone HT29-18-C1. Biochem J 1995;308:391-397.

52 Ohta A, Ohtsuki M, Baba S, Adachi T, Sakata T \& Sakaguchi E. Calcium and magnesium absorption from the colon and rectum are increased in rats fed fructo-oligosaccharides. I Nutr $1995 ; 125: 2417-2424$.

53 Younes $\mathbf{H}$, Demigné C \& Rémésy C. Acidic fermentation in the caecum increases absorption of calcium and magnesium in the large intestine of the rat. BrJ Nutr 1996;75:301-314.

54 Heijnen AM, Brink EJ, Lemmens AG \& Beynen AC. Meal pH and apparent absorption of magnesium in rats fed on diets containing either lactose or lactulose. Br J Nutr 1993; 70:747-756.

55 Scharrer $\mathrm{E} \&$ Lutz $\mathrm{T}$. Effects of short chain fatty acids and $\mathrm{K}$ on absorption of $\mathrm{Mg}$ and other cations by the colon and caecum. Z Ernährungswiss 1990;29:162-168. 


\section{Summary}

Deficiency of minerals and trace elements in humans and animals is often caused by a low bioavailability rather than by a low or deficient intake of these nutrients. Bioavailability can be defined as the fraction of the ingested nutrient that is absorbed and utilized for normal physiological functions or storage. One of the main determinants of bioavailability is absorption. This can be defined as the percentage of the element ingested that, after the digestion of food, has passed the mucosal cells and is taken up by the blood circulation.

Food ingredients that may stimulate or inhibit the absorption of minerals and trace elements are currently receiving much attention. Development in food technology, molecular biology and nutrition science has led to a growing market for novel and functional foods. Novel foods are just new foods, whereas functional foods are foods with specific additional beneficial effects on health or specific physiological functions. Some functional foods are also novel foods.

Before novel foods can enter the market their safety has to be assessed. Such assessments encompass safety from a toxicological as well as a nutritional point of view. The assessment of nutritional safety may include the effects of novel foods on bioavailability of minerals and trace elements. Before any claim of beneficial effects of functional foods on health can be put forward its functionality has to be demonstrated. This may include positive effects on bioavailability of minerals and trace elements.

This thesis deals with the development and application of new techniques (using stable isotopes) to measure the intestinal absorption of minerals and trace elements. Our aim was twofold: first, to develop a new method to measure iron absorption with a minimum use of stable isotopes in order to reduce the costs of the method, and second, to study the influence of several potential functional food ingredients on mineral and trace element absorption, using the dual stable isotope technique. The minerals and trace elements involved are calcium, magnesium and iron. The potential functional food ingredients involved are bovine lactoferrin, non-digestible oligosaccharides and lactulose.

A review of the literature on different methods for measuring Fe absorption by using 
isotopes can be found in Chapter 2. From this review it has been concluded that the method of choice for measuring Fe absorption appears to be the analysis of the incorporation of both an orally and an intravenously administered stable Fe isotope into erythrocytes, within 14 days after isotope administration. The only disadvantage of this method is the rather large amount of stable isotopes required in order to obtain a significant isotope enrichment in erythrocytes. Stable isotopes are expensive and, moreover, the amount of isotopes should not interfere with the maintenance of physiological conditions during absorption tests. Our idea was that a reduction in the dose could be obtained by measuring the incorporation of the isotopes into a reticulocyte-rich erythrocyte fraction. It is known that ca. $80 \%$ of newly absorbed Fe is incorporated into red blood cells within 2 weeks after administration. About half of that amount is present in young erythroid cells in the circulating blood after 3 to 4 days of administration. As erythrocytes live about 110 days, and every day only $0.9 \%$ of this cell population is replaced, the isotopes in the newly formed erythrocytes will be diluted strongly when they enter the circulation in the form of reticulocytes, the youngest erythroid cells. By preparing cell fractions rich in young erythroid cells it should be possible to find a higher isotope enrichment. Therefore, in blood drawn 3 to 14 days after oral and intravenous administration of two different stable Fe isotopes, reticulocyte-rich cell fractions were isolated by using a density separation method. In these cell fractions isotope enrichment was measured. The first effort, as described in Chapter 3, resulted in a significant enrichment of the intravenously administered isotope. However, no enrichment of the orally given isotope was found. The order in which the stable isotopes in this experiment were administered, might have interfered with the absorption of the orally given isotope.

In our second experiment the order of isotope administration was reversed; so that the oral dose of stable Fe isotopes was given ca. two hours before the intravenous dose (Chapter 4). Compared to the enrichment found in whole blood after 14 days, in reticulocyte-rich cell fractions a three-times higher isotope enrichment was found of both the orally and intravenously administered stable Fe isotopes. The absorption based on the isotope enrichment values in the reticulocyte-rich cell fractions was essentially the same as the absorption calculated from the isotope enrichment in 
whole blood. Because of the higher enrichment, the required dose of stable isotopes can be reduced to one-third of the doses used in the traditional method without loss of sensitivity. When labour is included this will resuit in a total cost savings of $35 \%$ for women and $55 \%$ for men.

Because the development of the new technique to measure true Fe absorption with the isolation of reticulocytes, stagnated, the traditional method with erythrocytes was used to measure the effect of bovine lactoferrin (Lf) and non-digestible oligosaccharides (NDO) on Fe absorption. Lactoferrin is a major iron-binding protein in milk from many species. Long-term feeding animal experiments as well as in vitro cell receptor studies have indicated that under conditions of increased iron needs, Lf promotes iron absorption. Therefore, in women with low iron stores the effect of bovine Lf, which may bind specifically to human target cells, on iron absorption was measured using the double stable isotope technique. Four treatments were given, which consisted of 3 different doses of bovine Lf and a control treatment. The Lf doses were chosen in such way that $\mathrm{Lf}$ was differently saturated with Fe. The results of this study are described in Chapter 5 . Neither an inhibitory nor a promoting effect of bovine Lf on Fe absorption was found. However, we cannot exclude completely the possibility that we have missed small treatment effects (an increase in absorption of less than about $8 \%$ ) due to the high within-subject variability in true intestinal Fe absorption. Nevertheless, the average absorption percentages of each treatment with a different Lf dose and of the control treatment were almost identical and no doseeffect relationship was present. We think this makes a positive effect of bovine Lf on Fe absorption unlikely.

Next to favourable effects of the ingestion of NDO on gastrointestinal function (faecal bulking, production of short-chain fatty acids) and metabolism (reduction of serum cholesterol, improved tolerance to glucose) positive effects of NDO on the absorption of minerals and trace elements have been found in rats. Therefore, we investigated the effect of $15 \mathrm{~g}$ of inulin, fructo-oligosaccharides (FOS), or galactooligosaccharides per day on $\mathrm{Fe}$ and $\mathrm{Ca}$ absorption in healthy men. As described in 
Chapter 6, neither an inhibitory nor a promoting effect on $\mathrm{Fe}$ and $\mathrm{Ca}$ absorption was found, which is relevant in view of safety of these functional food compounds. From studies on the bioavailability of $\mathrm{Fe}$ from a diet it appears that the effects of dietary variables that influence Fe absorption are particularly clear under conditions of a low Fe status of the body. The powerful control of Fe absorption against Fe overload of the body could explain why till now no effect of NDO on Fe absorption was found in human subjects. Therefore, we cannot exclude the possibility that NDO beneficially influences $\mathrm{Fe}$ absorption in man when Fe stores are low.

In these adult men, $\mathrm{Ca}$ absorption was measured by using the dual stable isotope technique. The enrichment of both isotopes was measured in a 24-h urine sample. It is possible that the slower late colonic component of Ca absorption, on which NDO probably exert their effect, has not reached completion within 24 hours. Besides, a positive effect could be more pronounced in young growing volunteers, due to their higher $\mathrm{Ca}$ requirements. Therefore, in the second study on NDO, $15 \mathrm{~g}$ of FOS was given to twelve healthy boys and urine collection was extended. As described in Chapter 7, $15 \mathrm{~g}$ of FOS stimulated Ca absorption. From the results of both studies described in Chapter 6 and 7, we may conclude that the FOS-induced enhancement may be dependent on the subject's Ca requirement and may take place predominantly in the large intestine.

Like NDO, lactulose is mostly fermented in the distal part of the intestinal tract. Possibly by a same mechanism, this synthetic disaccharide can stimulate $\mathrm{Ca}$ absorption. As no results of human studies on the influence of lactulose on Ca absorption are available, a study was conducted in a population group (postmenopausal women) who may benefit from the envisaged enhancing effect of lactulose on $\mathrm{Ca}$ absorption. As described in Chapter 8, the treatments consisted of 5 and $10 \mathrm{~g}$ of lactulose per day and a control treatment. Lactulose increased $\mathrm{Ca}$ absorption in postmenopausal women, without increasing urinary $\mathrm{Ca}$ excretion. This indicates that lactulose may also increase the uptake of Ca by the bones and/or inhibit bone resorption. The positive effect on $\mathrm{Ca}$ absorption was significantly related to the dose of lactulose. More research is warranted to explore how lactulose stimulates Ca 
absorption and whether it is able to improve the Ca balance in man and/or to decrease the rate of ageing bone loss.

As a consequence of fermentation of NDO in the large intestine short-chain fatty acids (SCFA) are produced and the $\mathrm{pH}$ decreases. This may play a role in the stimulating effect of $\mathrm{NDO}$ on both $\mathrm{Ca}$ and $\mathrm{Mg}$ absorption. Therefore, we also investigated the effect of $15 \mathrm{~g}$ of FOS on Mg metabolism in seven boys (Chapter 9). Although a common mechanism of the positive effect of FOS on $\mathrm{Ca}$ and $\mathrm{Mg}$ metabolism seemed to exist, FOS did not affect $\mathrm{Mg}$ metabolism in these adolescents. However, we should admit that the number of subjects in this study may have been too small to detect moderate effects. Moreover, since our study was performed only with an oral administration of a stable isotope and not by the application of a dual stable isotope technique (oral and intravenous administration), no final conclusion about the potential effects of FOS on $\mathrm{Mg}$ absorption can be drawn and further research into the role of FOS on $\mathrm{Mg}$ absorption in humans is recommended.

Referring to the aims mentioned in the introductory chapter of this thesis, the following conclusions are drawn:

- By measuring isotope enrichment in isolated young erythroid cells, Fe absorption can be determined with a smaller amount of administered stable isotopes than by measuring isotope enrichment in whole blood (the traditional method). The former procedure saves money and avoids interference with maintenance of physiological conditions during absorption tests.

- Our results did not provide evidence for a positive effect of bovine lactoferrin on Fe absorption in persons with low Fe stores.

- Our results showed that the bioavailability of $\mathrm{Ca}$ can be increased in adolescents by a feasible dose of $15 \mathrm{~g} / \mathrm{d}$ of fructo-oligosaccharides. Besides, the intake of nondigestible oligosaccharides, such as inulin, fructo-oligosaccharides and galactooligosaccharides, does not adversely affect Fe, Ca or Mg absorption.

- In postmenopausal women, $10 \mathrm{~g} / \mathrm{d}$ of lactulose stimulates $\mathrm{Ca}$ absorption. 


\section{Samenvatting}

Een tekort aan mineralen en spoorelementen kan worden veroorzaakt door een lage biologische beschikbaarheid zonder dat er sprake is van een tekort van deze elementen in de voeding. Biologische beschikbaarheid wil zeggen dat deel van het ingenomen element dat via de darm wordt opgenomen en wordt benut door het lichaam. Momenteel is er veel aandacht voor voedingsstoffen die mogelijk de absorptie kunnen stimuleren of remmen. Voedingsmiddelen met deze (soms nieuwe) voedingsstoffen worden ook wel 'functional foods' genoemd. Dit zijn voedingsmiddelen die met opzet zo zijn samengesteld dat ze ten opzichte van de traditionele voedingsmiddelen een gezondheidsbevorderend effect hebben, zoals bijvoorbeeld 'een positief effect op de biologische beschikbaarheid van mineralen en spoorelementen'. Voordat er zo'n claim over een gezondheidsbevorderend effect aan een 'functional food' kan worden toegekend, dient de claim voldoende onderbouwd te zijn met wetenschappelijke bewijzen. In de experimenten beschreven in dit proefschrift werd daarom onderzocht of de 'functional foods', lactoferrine en nietverteerbare koolhydraten, de absorptie van mineralen en spoorelementen bij de mens beïnvloeden. Het was al bekend dat deze 'functional foods' de absorptie bij dieren verhogen.

\section{Methoden om absorptie te meten}

Om de invloed van verschillende 'functional foods' op de opname van mineralen en spoorelementen nauwkeurig te kunnen bepalen dient gebruik te worden gemaakt van radioactieve of stabiele isotopen. Vanwege het gevaar van blootstelling van de proefpersoon aan radioactiviteit, komen radioactieve isotopen voor het voedingsonderzoek bij gezonde proefpersonen niet in aanmerking. Daarom is in het in dit proefschrift beschreven onderzoek gebruik gemaakt van stabiele isotopen. Het onderzoek heeft zich geconcentreerd op de absorptie van de elementen calcium, magnesium en ijzer.

\section{Stabiele isotopen}

Elk element bestaat van nature uit isotopen. De stabiele isotopen van calcium, ijzer of magnesium, welke het minst voorkomen in de natuur, zijn gebruikt in onze 
onderzoeken. Een mengsel van isotopen van het betreffende element met daarin een grote hoeveelheid van dit minst voorkomend stabiele isotoop is commercieel verkrijgbaar. Wanneer zo'n verrijkt mengsel wordt toegediend aan het lichaam wordt de natuurlijke verhouding van de stabiele isotopen in het lichaam veranderd. In de door ons toegepaste methode, de zogenaamde dubbel-label techniek, werd van éen element twee stabiele isotopen gegeven, één met de voeding en een ander werd direct in de bloedbaan geĩnjecteerd (intraveneuze toediening, dus $100 \%$ absorptie). Een deel van het geinjecteerde of geabsorbeerde calcium of magnesium wordt uitgescheiden via de urine. Uit de verhouding van de stabiele isotopen in de urine kan de absorptie van calcium of magnesium worden berekend.

Voor ijzer ligt dit iets anders. De uitscheiding van ijzer via de urine is veel te laag om deze te kunnen gebruiken voor metingen van ijzerabsorptie. Wel is het mogelijk ijzer in de rode bloedcellen te meten. Het overgrote deel van het opgenomen ijzer wordt namelijk ingebouwd in rode bloedcellen. Daarom kan uit de verrijking van de rode bloedcellen met stabiele isotopen, de absorptie van ijzer worden berekend. Het nadeel van deze methode is dat een relatief grote hoeveelheid aan stabiele ijzerisotopen nodig is om een voldoende en goed meetbare verrijking van de rode bloedcel te verkrijgen. Dit maakt de methode behoorlijk duur, terwijl er gevaar bestaat dat de grote dosis interfereert met de normale weg van ijzer door het lichaam. Daarom zijn we op zoek gegaan naar een betere methode.

\section{Nieuwe methode}

Tachtig procent van het opgenomen ijzer wordt binnen 2 weken ingebouwd in de rode bloedcellen en met name in de jonge rode bloedcellen. Daar rode bloedcellen ongeveer 110 dagen leven en elke dag maar $1 \%$ van deze cellen wordt vervangen, wordt de verrijking van de jonge rode bloedcellen met het ingebouwde stabiele ijzerisotoop sterk verdund door het al aanwezige ijzer in de oudere rode bloedcellen. Uit de experimenten beschreven in hoofdstukken 3 en 4 blijkt het mogelijk om jonge rode bloedcellen van de oude rode bloedcellen te scheiden. Hierdoor kan verdunning worden voorkomen en is het mogelijk een hogere verrijking met de stabiele isotopen te verkrijgen. De absorptie, berekend op basis van de verrijking van de jonge rode 
bloedcellen (nieuwe methode), was gelijk aan de absorptie, berekend uit de verrijking van alle rode bloedcellen (traditionele methode). Aangezien de verrijking van de jonge rode bloedcellen drie keer zo hoog was als bij de traditionele methode, is in de nieuwe methode een veel lagere dosis aan stabiele ijzerisotopen nodig. Hierdoor kunnen de kosten worden gereduceerd.

Helaas kostte de ontwikkeling van de nieuwe methode meer tijd dan verwacht. Daarom is in de experimenten, beschreven in de volgende alinea's, nog gebruik gemaakt van de traditionele methode om ijzerabsorptie te meten.

\section{Effecten van 'functional foods'}

Het doel van de volgende experimenten was het nagaan van effecten van potentiële 'functional foods' op de absorptie van ijzer, calcium of magnesium. De bestudeerde 'functional foods' waren lactoferrine uit koemelk en de niet-verteerbare koolhydraten.

\section{Lactoferrine}

Lactoferrine is een eiwit dat voorkomt in melk. Naast bacterie-dodende eigenschappen, wordt aan lactoferrine het verhogen van de ijzerabsorptie toegekend, indien er sprake is van een ijzertekort. Dit laatste is echter gebaseerd op dierexperimenten. Wij wilden nagaan of lactoferrine uit koemelk ook de ijzerabsorptie stimuleert bij mensen met een ijzertekort. Daartoe kregen vrouwen met een lage ijzervoorraad drie verschillende hoeveelheden lactoferrine. Geen positief effect op de ijzerabsorptie werd gevonden, maar we kunnen niet uitsluiten dat we kleine effecten van lactoferrine op de ijzerabsorptie $(<8 \%)$ hebben gemist, doordat de ijzerabsorptie binnen personen erg varieerde. Desondanks was er nagenoeg geen verschil in ijzerabsorptie tussen de behandelingen met en zonder lactoferrine en nam de ijzerabsorptie niet toe met een grotere dosis aan lactoferrine. Wij zijn daarom van mening dat onder de condities van het uitgevoerde experiment een positieve werking van lactoferrine op de ijzerabsorptie zeer onwarschijnlijk is. 


\section{Niet-verteerbare koolhydraten}

Niet-verteerbare koolhydraten zijn voedingsbestanddelen welke niet worden verteerd door enzymen in het maagdarmkanaal, maar uiteindeli $\mathrm{k}$ wel worden afgebroken door bacteriën in het laatste deel van de darmen. Bij deze afbraak komen bepaalde stoffen vrij, waaraan gezondheidsbevorderende eigenschappen worden toegekend, zoals bijvoorbeeld een positief effect op het maag-darmkanaal (laxerend effect) en op het functioneren van het lichaam in het algemeen (verlaging serum cholesterol, toename van de glucose tolerantie). Uit experimenten met ratten blijkt verder dat nietverteerbare koolhydraten de ijzer-, calcium- en magnesiumabsorptie stimuleren. Dit laatste hebben we nagegaan bij de mens.

In onze experimenten zijn de niet-verteerbare oligosacchariden, inuline, galacto- en fructo-oligosacchariden, alsmede het niet verteerbare disaccharide, lactulose onderzocht.

\section{Oligosacchariden}

Er wordt geschat dat Europeanen via hun voeding vijf gram van de niet-verteerbare oligosacchariden per dag eten. De belangrijkste bron is tarwe, gevolgd door ui en banaan. In ons eerste experiment is de ijzer- en calciumabsorptie gemeten bij volwassen mannen (20-30 jaar), die $15 \mathrm{~g}$ van de volgende oligosacchariden, inuline, fructo-oligosacchariden en galacto-oligosacchariden extra innamen. Uit de resultaten van clit onderzoek, beschreven in hoofdstuk 6 , kan worden geconcludeerd dat deze oligosacchariden geen positief, noch een negatief effect hebben op de ijzer- en calciumabsorptie bij deze proefpersonen.

Het is verklaarbaar waarom een positief effect van oligosacchariden op de ijzerabsorptie niet werd gevonden. Het onderzoek werd uitgevoerd bij mannen met een goede ijzerstatus. Onder deze omstandigheden van een goede ijzerstatus, zal de ijzerabsorptie in de darm bijzonder laag zijn, doordat de darm dan een barrière opwerpt tegen de absorptie van ijzer. Accumulatie van ijzer in het lichaam kan schadelijke effecten hebben en daarom is verhoging van de ijzer absorptie dus feitelijk ongewenst. Dit kan verklaren waarom in ons onderzoek geen effect van oligosacchariden op de ijzerabsorptie werd gevonden. 
Bij calciumabsorptie ligt dit heel anders. Er wordt wel gesuggereerd dat oligosacchariden met name positief werken op de calciumabsorptie in de dikke darm (het laatste deel van de darmen). In de door ons toegepaste methode om calciumabsorptie te meten werd de verrijking met stabiele isotopen gemeten in urine, verzameld gedurende 24 uur na isotoop toediening. Het kan zijn dat 24 uur niet lang genoeg was voor de meting van de totale calciumabsorptie. Daarom werd in een tweede experiment de urineverzameling verlengd tot 36 uur. Dit keer waren de proefpersonen 12 jongens in de leeftijd van 14 tot 16 jaar. Op deze leeftijd is de calciumbehoefte verhoogd door de groei, waardoor een positief effect op de absorptie misschien beter tot uiting kan komen. Zoals in hoofdstuk 7 te lezen valt, werd nu wel een positief effect van $15 \mathrm{~g}$ fructo-oligosacchariden op de calciumabsorptie gevonden. Mogelijk is dit positieve effect dus afhankelijk van de calciumbehoefte en/of vindt het effect inderdaad voornamelijk plaats in de dikke darm.

Bij 7 van deze jongens is ook het effect van fructo-oligosacchariden op de magnesium uitscheiding onderzocht (zie hoofdstuk 9). Door omstandigheden (o.a. te weinig geleverde stabiele isotopen) kon het effect op de magnesiumabsorptie niet worden gemeten. Daarom is alleen een stabiel magnesiumisotoop gegeven met de voeding. Wanneer wordt aangenomen dat de uitscheiding van geïnjecteerd en geabsorbeerd magnesium op dezelfde wijze door fructo-oligosacchariden wordt beinvloedt, zeggen verschillen in de uitscheiding van het gegeven isotoop iets over de magnesium absorptie. Wij vonden een verhoging van de uitscheiding van het isotoop als gevolg van de behandeling met oligosacchariden, maar deze was niet significant. Aangezien het onderzoek werd uitgevoerd met een klein aantal proefpersonen kan een positief effect niet worden uitgesloten, temeer daar bij deze zelfde jongens wel een positief effect werd gevonden op de calcium absorptie.

\section{Lactulose}

Lactulose, een synthetisch disaccharide, bereikt net als oligosacchariden bijna in zijn geheel de dikke darm en wordt daar gefermenteerd. Lactulose kan waarschijnlijk via hetzelfde mechanisme als oligosacchariden de calciumabsorptie beinvloeden. Dit 
werd onderzocht bij postmenopausale vrouwen, een bevolkingsgroep die veel baat zouden hebben bij een 'functional food' dat de calciumabsorptie verhoogt. Zij kregen naast een controlebehandeling zonder lactulose, gedurende 9 dagen, een drank met 5 of $10 \mathrm{~g}$ lactulose aageboden. De volgorde van de drie behandelingen werd door toeval bepaald. Het bleek dat $10 \mathrm{~g}$ lactulose per dag inderdaad de calciumabsorptie bij deze vrouwen verhoogt, zonder dat dit gepaard gaat met een toename van de calciumuitscheiding in de urine. Dit laatste kan inhouden dat het extra calcium dat wordt opgenomen, ten gevolge van het lactulose, ten goede komt aan de botten. Verder bleek de calciumabsorptie toe te nemen bij een hogere dosis lactulose.

Een vervolgonderzoek naar het mechanisme achter het positieve effect van lactulose en de andere niet-verteerbare koolhydraten op de calciumabsorptie is aan te bevelen. Verder zou het interessant zijn om te onderzoeken of het extra calcium dat wordt opgenomen uit de voeding ten gevolge van lactulose en fructo-oligosacchariden, daadwerkelijk benut wordt voor botopbouw.

\section{Conclusies}

Uit de resultaten van dit proefschrift kan het volgende worden geconcludeerd:

- Bij het bepalen van de ijzerabsorptie met behulp van de dubbel-label techniek kan een 3 keer zo hoge verrijking van rode bloedcellen met stabiele ijzerisotopen worden verkregen, wanneer jonge rode bloedcellen hiervoor worden geïsoleerd. Hierdoor kan de ijzerabsorptie goedkoper en onder meer fysiologische omstandigheden worden gemeten.

- Bij vrouwen met een lage ijzerstatus heeft lactoferrine zeer waarschijnlijk geen positief effect op de ijzerabsorptie.

- Bij jongens in de leeftijd van 14 tot 16 jaar verhoogt $15 \mathrm{~g}$ fructo-oligosacchariden per dag de calciumabsorptie. Verder maken de resultaten uit dit proefschrift duidelijk dat niet-verteerbare oligosacchariden zoals inuline, fructo- en galactooligosacchariden in ieder geval geen negatief effect hebben op de opname van ijzer, calcium en magnesium uit de voeding.

- Lactulose $(10 \mathrm{~g} / \mathrm{d})$ stimuleert de calciumabsorptie bij postmenopausale vrouwen. 


\section{Dankwoord}

Het is zover. Hier heb ik jaren over nagedacht terwijl ik op en neer fietste van Utrecht naar TNO. Hoe zal ik het doen, en criminele, als ik maar niemand vergeet te bedanken. Was ik toen maar vast begonnen met het opschrijven van namen of een stukje tekst, maar nee, het moet nu, enkele dagen voordat dit boekje naar de drukker gaat. Maar goed, laat ik nu dan maar snel beginnen, want tja iedereen weet, dit proefschrift heb ik beslist niet alleen tot stand gebracht.

De eerste personen die ik wil bedanken zijn mijn begeleiders Gertjan Schaafsma en Wim van Dokkum. Jullie hebben er altijd vertrouwen in gehad dat dit allemaal zou lukken. Gertjan, ik heb onze gesprekken erg gewaardeerd. Jouw optimisme, wanneer bijvoorbeeld de isotopen geen isotopen bleken, maar ook tijdens het schrijven zal ik onthouden. Bedankt ook nog voor dat ritje achter op de motor naar IJmuiden en voor al die "vrouw-onvriendelijke" grapjes (door je vertelkunst werden ze zowaar komisch). Wim van Dokkum, jij was een aanspreekpunt wanneer ik weer eens iets had. Jouw adviezen en positieve uitstraling waren erg belangrijk voor mij. Ik heb er bewondering voor hoe je wetenschap kan combineren met magie en muziek (tijdens presentaties, tijdens werk en vermoedelijk ook thuis).

Wim Saris, mijn eerste promotor. Ik hoop dat je me de hoge tijdsdruk die ik jou zo nu en dan oplegde hebt vergeven. Graag wil ik je bedanken voor de suggesties voor met name de inleiding en discussie van dit proefschrift en voor je gastvrijheid bij de vakgroep Humane Biologie tijdens de lactoferrine proef.

Tja, heel veel mensen hebben bij de uitvoer van de proeven geholpen. Zonder hun zou het een chaos zijn geweest. Wilfred Sieling, Inge van Assum, Petra van Aken, Hanny Leezer en Hélène de Vries, bedankt voor het vroege opstaan, de stress over de werving van proefpersonen, de humor op de raarste momenten, kortom voor jullie hulp en inzet. Verder wil ik ook Edgar van Mill en Carolien van Tuijl bedanken voor hun hulp tijdens de lactoferrine proef in Maastricht. 
Bijna 70 proefpersonen hebben bijgedragen aan dit proefschrift. Deze mensen leverden meerdere bloed- en urinemonsters, die allemaal moesten worden geanalyseerd op isotoop ratios en totaal ijzer, calcium of magnesium. In de eerste weken overtuigde Theo Muijs mij -gelukkig- dat 4 jaar veel te kort is om de ICP-MS te leren bedienen. En dat heeft le geweten. Theo, je was de drijvende kracht achter al dit werk, jij en je collega's bedankt voor alle hulp.

Nu ik het over de ICP-MS heb, denk ik aan Joop Luten. Joop, bedankt voor het meedenken over o.a. de ijzermethode en de analyses naar ijzerratio's.

Waar zou de reticulocyt-methode zijn geweest zonder Hillie Pellegrom? Dat heb ik me regelmatig afgevraagd. "Is de goede Percoll op; daar gaan we achteraan. Meer dan 80 monsters per dag verwerken, tja, moet kunnen". Hillie, je bent een geweldig mens, ik vond het heerlijk om met je samen te werken, nog bedankt. En natuurlijk ook Joost Bruyntjes en Steven Spanhaak bedankt voor het meedenken en de hulp bij het scheiden van de oude en jonge rode bloedcellen.

Jan Catsburg, bedankt voor het analyseren van alle bloed- en urinemonsters voor de in- en uitkeuringen van de proefpersonen.

I would like to thank Sue Fairweather-Tait for her critical comments to Chapter 3. Jan Steijns, jij ook bedankt voor je commentaar op Hoofdstuk 5.

In de jaren bij TNO heb ik regelmatig van werkplek moeten veranderen. Eerst kwam ik te zitten met o.a. Wim, Gertjan, Henk Hendriks, Henk van de Berg, Trinette van Vliet in de gele cabine, en wel in de kamer van Anneke Engelgeer tegenover die van Erica Velthuis. Een gezellige boel was het daar, ondanks de oplopende temperaturen. Na Anneke, kwam Liesbeth Schulp op mijn kamer. De gezelligheid en bereidheid tot hulp werd er niet minder om. Liesbeth, Petra, Wil van der Heijdt en Carolien wisselden elkaar af met het helpen bereiden van de bekertjes met jus d'orange ( 3 per dag voor 12 personen en dat 3 maanden lang!). Bedankt voor jullie hulp. In de laatste 
periode in de cabines werd Ada van Schaik mijn kamergenoot. Ada, we zijn goede maatjes geworden, bedankt voor je luisterend oor en je 'altijd-vrolijkheid'. Na de gele cabine kwam ik met Angela Severs op een kamer in gebouw 9. De combinatie vitaminen en mineralen/spoorelementen ging heel goed samen. Vervolgens verhuisden we met de hele afdeling naar gebouw 12. Hier deelde ik een kamer met Martijn van der Gaag en stagaires en later met Marian Bouterse. Nou de laatste loodjes wegen het zwaarst zullen we maar zeggen, dus aan mij hebben jullie niet veel gezelligheid gehad. Bedankt voor jullie steun. Tja, verder wil ik natuurlijk alle collega's bedanken die ik de afgelopen jaar heb gehad en ik moet zeggen, het blijft gezellig, ook met de nieuwe collega's die er nu regelmatig bijkomen.

De rest van de divisie wil ik hier niet vergeten. De gezamenlijke koffiepauzes werden de laatste tijd wat minder, maar gelukkig zijn er altijd momenten waarop we elkaar tegenkomen in gebouwtje 11. Een paar mensen wil ik in het bijzonder noemen: Cor Kistemaker, bedankt voor je hulp bij de statistische verwerking van alle getallen. Arthur van Aken, bedankt voor de informatie over Excell, Power-point, en noem maar op. Tinneke Brussaard, bedankt voor je inhoudelijk commentaar op de discussie. Willy van Dijk en Hanny, bedankt voor jullie hulp bij het 'lay-outen'. Lucy van de Vijver en Adriaan Kole, jullie waren echte (AIO-)maatjes. Maar natuurlijk waren er ook andere AIO's en ex-AIO's: het was gezellig en goed om af en toe (bij een pilsje) ervaringen met jullie uit te wisselen.

Ook buiten TNO hebben een aantal mensen behoorlijk bijgedragen aan dit proefschrift. Ten eerste is dat Margriet Spangenberg, vriendin vanaf de box. Samen met je moeder heb je met die verrekte spelletjes mij waarschijnlijk aangezel tot verder studeren. Margriet, bedankt voor je hulp bij het Engels en voor het feit dat je mijn paranimf wilt zijn. Verder wil ik bedanken mijn familie en vrienden, die me vooral het laatste jaar nauwelijks hebben gezien. Jullie interesse in mijn werk werd er niet minder om. Met name mijn vader, moeder, Peter, Els Mol en José Muijlwijk will ik bedanken voor jullie altijd stimulerende belangstelling. 
Ten slotte, Carolien, ik heb je al een aantal malen genoemd, maar je hebt nog veel meer gedaan en daar was 'ref-managing' niks bij. Bedankt en de komende jaren gaan we zeker samen lang op vakantie! 


\section{Curriculum vitae}

Ellen van den Heuvel was born on the 12 th of July 1966, in Vlijmen, the Netherlands. In 1984 she finished secondary school at the 'Rijksscholengemeenschap' (MAVO and HAVO) in s'Hertogenbosch. In the same year she started the study for dietician at the HBO-academy in Nijmegen. From April 1989 till August 1990 she worked as a research assistant on cognitive functions of dietary intake at the Department of Human Biology of the University of Limburg in Maastricht. In 1990, she started the study 'Human Nutrition' at Wageningen Agricultural University. Major subjects of study were human and animal physiology. During this study she spent four months of practical research at the Rowett Research Institute in Aberdeen, Scotland. In January 1994, she started as a PhD fellow at the Department of Human Biology of the University of Limburg in Maastricht (head: Prof. Dr W.H.M. Saris). Her working place was TNO Nutrition and Food Research Institute, Department of Physiology, in Zeist, where she will continue her work as a project manager. 
172 


\section{Publications}

Van den Heuvel EGHM, Van Dokkum W \& Schaafsma G. Methods to measure iron absorption in man: A review. Food Rev Int 1997;13:91-102.

Van den Heuvel EGHM, Schaafsma G, Muijs Th \& Van Dokkum W. Nondigestible oligosaccharides do not affect calcium and non-heme iron absorption in young healthy men. Am J Clin Nutr 1998;67:445-452.

Van den Heuvel EGHM, Muijs Th, Van Dokkum W \& Schaafsma G. Fructooligosaccharides stimulate calcium absorption in adolescents. (Submitted for publication).

Van den Heuvel EGHM, Muijs Th, Van Dokkum W \& Schaafsma G. Lactulose stimulates Ca absorption in postmenopausal women. (Submitted for publication).

Van den Heuvel EGHM, Saris WHM, Muijs Th \& Schaafsma G. Iron absorption study with stable isotopes in women with low iron stores: effect of bovine lactoferrin. (Submitted for publication).

Van den Heuvel EGHM, Muijs Th, Pellegrom H, Bruyntjes JP, van Dokkum W, Spanhaak S \& Schaafsma G. A new method to measure iron absorption from the enrichment of ${ }^{57} \mathrm{Fe}$ and ${ }^{58} \mathrm{Fe}$ in young erythroid cells. Clin Chem 1998. (In press).

Van Dokkum W, Havenaar R, Wezendonk B, Srikumar TS \& Van den Heuvel EGHM. Effect of non-digestible oligosaccharides on large bowel functions, blood lipid concentrations and glucose absorption in young healthy male subjects. (Submitted for publication).

Visser M, Heuvel EGHM van den \& Deurenberg P. Prediction equations for the estimation of body composition in the elderly using anthropometric data. $\mathrm{Br} J$ Nutr 1994;71:823-833.

Westerterp-Plantenga MS, Van den Heuvel EGHM, Wouters L \& Ten Hoor F. Diet-induced thermogenesis and cumulative food intake curves during meals of familiar an unfamiliar food, as a function of dietary restraint. Int J Obes 1990;14:53.

Westerterp-Plantenga MS, Van den Heuvel EGHM, Wouters L \& Ten Hoor F. Subjects" estimation of their forthcoming ingestion of familiar and unfamiliar food as a funciton of dietary restraint. Int J Obes 1990;14:169. 
Westerterp-Plantenga MS, Van den Heuvel EGHM, Wouters L \& Ten Hoor F. Dietary restraint and preload effects during a dieting period. Int J Obes 1991;15:91. Westerterp-Plantenga MS, Van den Heuvel EGHM, Wouters L \& Ten Hoor F. Counterregulation as a function of cognitive restraint? In: Obesity in Europe 91. Ailhaud G, Guy-Grand M, Lafontain M, Ricquier D, eds. John Libbey \& Co Ltd. London-Paris, 1991:431-435.

Westerterp-Plantenga MS, Van den Heuvel EGHM, Wouters L \& Ten Hoor F. Accuracy of estimates of forthcoming ingestion as a function of menu familiarity and dietary restraint. Appetite 1992;18:101-109.

Westerterp-Plantenga MS, Van den Heuvel EGHM, Wouters L \& Ten Hoor F. Diet-induced thermogenesis and cumulative food intake curves as a function of familiarity with food and dietary restraint in humans. Physiology \& Behavior 1992;51:457-465.

\section{Abstracts}

Van den Heuvel EGHM, Muijs Th, Luten J \& van Dokkum W. The effect of nondigestible oligosaccharides on iron absorption in men. J Trace Elem Exp Med 1995;8:122.

Van den Heuvel EGHM, Muijs Th \& van Dokkum W. The effect of non-digestible oligosaccharides on calcium absorption in men. In: Annual meeting 1996. The role of trace elements for health promotion and disease prevention. Copenhagen, Denmark, 22-24 August 1996:103.

Van den Heuvel EGHM, Van Dokkum W, Muijs Th \& Schaafsma G. Nietverteerbare oligosacchariden, effect op calcium- en ijzerabsorptie. Voeding 1996;57:30.

Van den Heuvel EGHM, Muijs Th,Van Dokkum W \& Schaafsma G. Fructo oligosaccharides stimulate calcium absorption in adolescents. In: Proceedings of the International Symposium 'Non-digestible oligosaccharides: healthy food for the colon?'. ISBN 90-6754-510-4. Wageningen, the Netherlands, 4-5 December 1997:154. 
Van den Heuvel EGHM, Muijs Th, Pellegrom H, Bruyntjes JP, van Dokkum W, Spanhaak S \& Schaafsma G. A new method to measure iron absorption from the enrichment of ${ }^{57} \mathrm{Fe}$ and ${ }^{58} \mathrm{Fe}$ in young erythroid cells. In: Book of abstracts. International Symposium 'Bioavailability '97'. ISBN 90-6754-492-2. Wageningen, the Netherlands, 25-28 May 1997:22.

Van den Heuvel EGHM, Muijs Th,Van Dokkum W \& Schaafsma G. Fructo oligosaccharides stimulate calcium absorption in adolescents. In: Functional properties of non-digestible carbohydrates'. Guillon F, Amado R, Amaral-Collaço MT, Andersson H, Asp NG, Bach Knudsen KE, Champ M, Mathers J, Robertson JA, Rowland I, Van Loo J, eds. ISBN 2-7380-0809-7. Lisboa, Portugal, 5-7 March 1998:138.

Westerterp-Plantenga MS, Van den Heuvel EGHM, Wouters L \& Ten Hoor F. Fysiologische en cognitieve aspecten van de voedselopname bij mensen. Voeding 1990;51:20. 